\title{
14. CENOZOIC RADIOLARIANS OF THE ANTARCTIC, LEG 29, DSDP
}

\author{
M. G. Petrushevskaya, Institute of Zoology, Academy of Sciences, Leningrad, USSR
}

\section{INTRODUCTION}

\section{Methods and Materials}

The samples from Leg 29 were mounted in balsam without additional shipboard processing, and then studied and photographed by means of a lightmicroscope. Since the details of the skeletal structure are frequently indistinguishable on the photographs, the author made additional hand drawn illustrations. Four samples were specially washed in order to study the radiolarian skeletons by means of a scanning electron microscope.

Special attention was paid to the almost continuous and comparatively undisturbed sequence obtained at Site 278. Other sites of Leg 29 which were studied are shown in Figure 1.

These data were compared with the radiolarians in the cores of bottom sediments, taken in the Antarctic and subantarctic by the R/V $O b$ and Eltanin. Such a comparison was necessary, since some of these cores $(\mathrm{Ob}$ Station 256, Eltanin, E-14-8, E-13-4) can be considered as stratotypical for the Pleistocene, Pliocene, and even the uppermost Miocene of high southern hemisphere latitudes. Neither the radiolarian species composition in the studied area, nor the schemes of radiolarian biostratigraphy were known from earlier (older) layers. As a result of the studies herein it was concluded that an age determination of Eocene, Oligocene, and Miocene deposits in the area between $45^{\circ}-55^{\circ} \mathrm{S}$ lat is quite possible by means of radiolarians. For the Antarctic Miocene deposits, a rather detailed stratigraphic scheme was suggested.

The discussion to follow is supported by data contained in Tables 1-8, and illustrations contained on Figures 1-10.

\section{Purpose and Investigative Problems}

Since the stratigraphy and isolation of "radiolarian zones" is based on the temporal and spatial distribution of individual species, the goal of this micropaleontological study is to establish the limits and content of the individual radiolarian species.

During recent years the word "population" is often used in the literature on fossil radiolarians. However, the complex of skeletons in bottom sediments represents a thanatocoenosis, whereas the skeletons of one species

\footnotetext{
'Editor's footnote: We were unable to confirm from the author many of the reference citations used in this manuscript. Most of these citations are those with the same reference year, while other references were not found. All those unestablished will be noted with a (?).
}

contained in a small volume of bottom sediment cannot be considered as remains of one population. Thus: (1) they accumulated for hundreds or even thousands of years; and (2) these skeletons might belong to specimens which inhabited various depths and belonged to populations of various natures. Petrushevskaya (1969a, 1971a) has stressed that using the term "population" with regard to radiolarian remains in one bottom sediment sample is not justified.

The species characteristics in micropaleontological investigations are generally rather poor. Thus, if an investigator deals essentially with the peculiarities of the skeleton morphology, the question arises whether the investigator is dealing with a biological species or with some tentative unit, i.e. "morphotype," according to the terminology of Riedel and some other American authors.

\section{Species Content}

Aside from these problems, there is need to discuss the question of species content in micropaleontological investigations. In the present study, in tracing by sections (which, for example, encompass the Upper Oligocene-Pliocene) for the distribution of species such as Diplocyclas bicorona or Antarctissa capitata, it was necessary to consider these species "sensu lato," i.e., in a broader sense than in previous studies which were confined to a shorter time interval (Holocene or Recent). This is due not only to the fact that more specimens (at smaller magnifications) had to be analyzed, but also that a more detailed division of these taxonomic units and the isolation of subordinate groups within their range did not correspond to the task of the investigations. The term "species group" seems justified here. The term was initially used by Riedel (Riedel and Sanfilippo, 1970, 1971; Sanfilippo and Riedel, 1970, 1973). These are, of course, not species, but groups of morphologically extremely closely related forms, which are clearly differentiated from other radiolarians encountered in the same sediments. Such "species-groups" will probably correspond to the generic categories of biologists. The study of the temporal and spatial distribution of such comparatively easily distinguishable groups is a real problem in view of the extremely short time available for the work. On the other hand, the "species groups," (as has been shown by the experience of a number of cruises) yield a sufficiently reliable basis for the determination of age and stratigraphic correlations.

Frequently the observed disappearance or reduced numbers of one "morphotype" and the appearance of a great number of specimens of another very close type can be regarded as either a new state of the species, or the appearance of a new species (Riedel and Sanfilippo, 

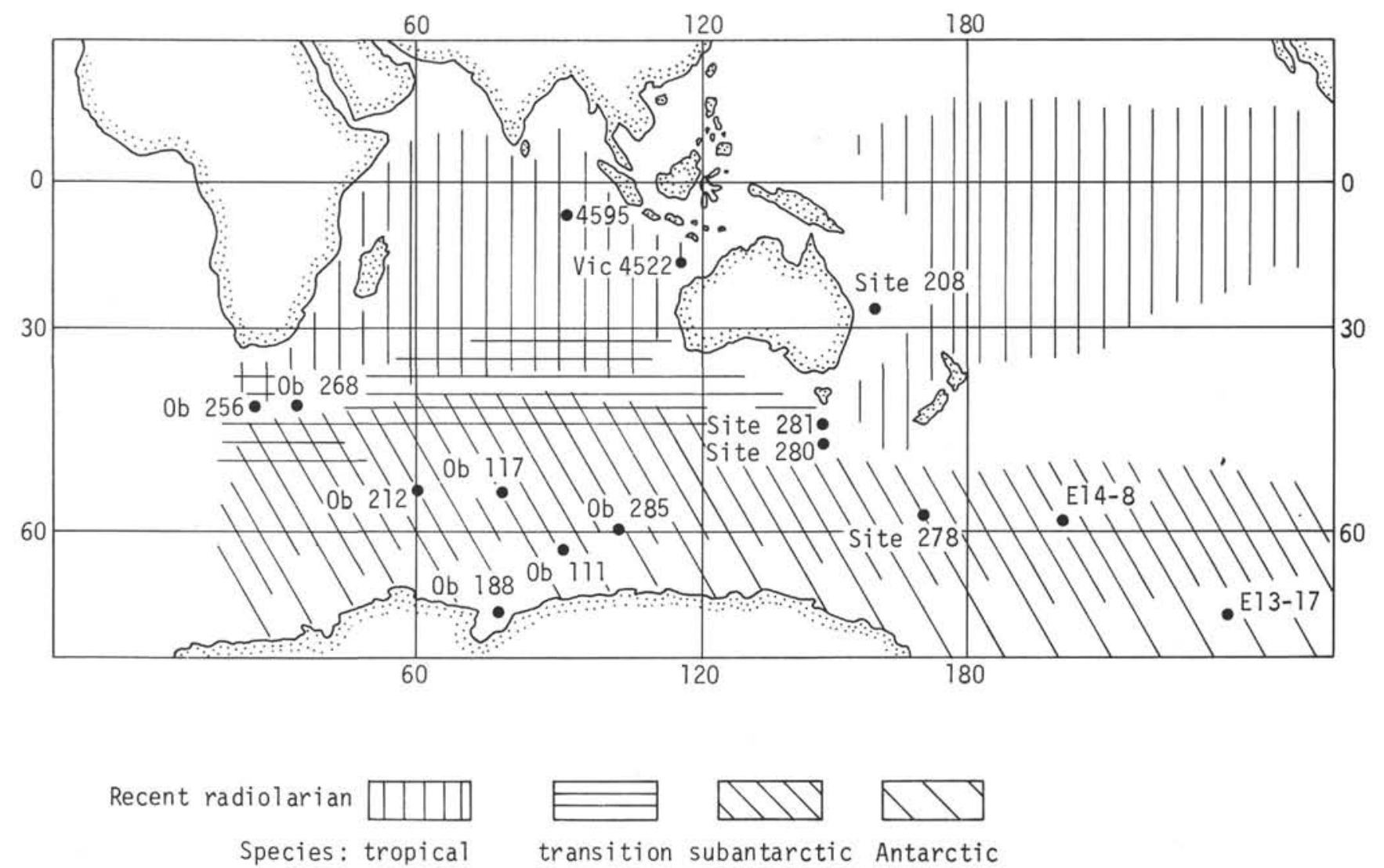

Figure 1. Recent radiolarian species distribution in the subantarctic southwest Pacific and Leg 29 site and sampling locations.

1971). Establishing the temporal limits of the taxon by the numerical predominance of the corresponding "morphotype" is really possible for such abundant forms as Stichocorys wolffii, $S$. delmontense, and $S$. peregrinus, or such species as Cannartus. In these cases, the appearance of only one taxon at a time is assumed. Figure 2 shows how the boundaries of five species which consecutively replace one another are determined. The appearance of one single species ("morphotype") which replaced the original one actually occurred in the history of Polycystina; for example, the development of the Pliocene Pterocanium prismatium Riedel from the Oligocene form described by Petrushevskaya (?1973, fig. $5)$, or the derivation of Saccospyris antarctica from $S$. preantarctica (this study).

However, it is hard to assume that the consecutive replacement of the predominant "morphotype" ("morphotypic-evolutionary" or "evolutionary" limits between taxa [Sanfilippo and Riedel, 1973]) is the basic and only mechanism of radiolarian evolution. Beginning with Darwin, divergence is considered as the basic course of the evolution of all animals. Two forms, which most strongly differ from one another in all characteristics, survive, whereas the intermediate forms sooner or later become extinct. The appearance of only one single form is considered as a more infrequent phenomenon. In biology, it is also assumed that species evolution could have been "bouquet-like" when many species appeared at once.

Thus, the determination of the actual temporal limits of the species can, in some cases, be based on the fact that there are two (rarely more) daughter species, which came in as a replacement of the ancestral one.

Very often in the study of continuous sections (especially in the case of a low rate of sediment accumulation), the traces and evidence of evolutionary changes, which took place in the history of a particular radiolarian group, present a rather complicated picture. The more numerous the specimens of this group, the more complicated the picture. Consider the samples corresponding to the time period " $M$ " shown on Figure 3. It is difficult to decide (merely on the basis of the morphological peculiarities and the numerical strength of the "morphotypes"), whether there is only the ancestral species "P" with its characteristic polymorphism, or whether there are three species $(\mathrm{Pa}$; $\mathrm{Pb}, \mathrm{c}, \mathrm{d}, \mathrm{e}$; Pf) or even six species (= morphotypes?): PA, PB, PC, PD, PE, and PF. The new state of the ancestral species, due to some cause ("q" on Figure 3) should not necessarily have affected the morphology of all morphological forms of the initial species with an equal degree of speed and distinctness. Later, when the two 
successively younger morphotype

forms :

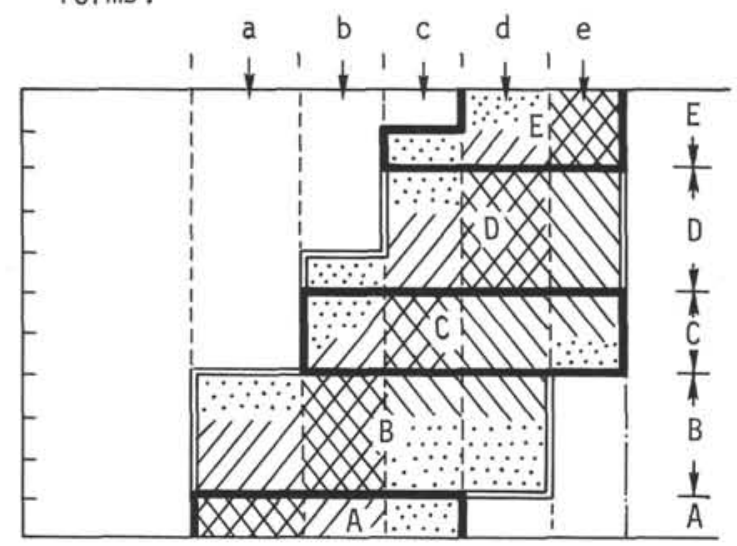

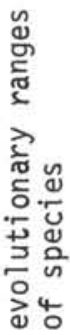
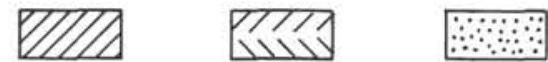

abundant

frequent

rare

Figure 2. Boundaries of five species as determined by the appearance of one taxon at a time.

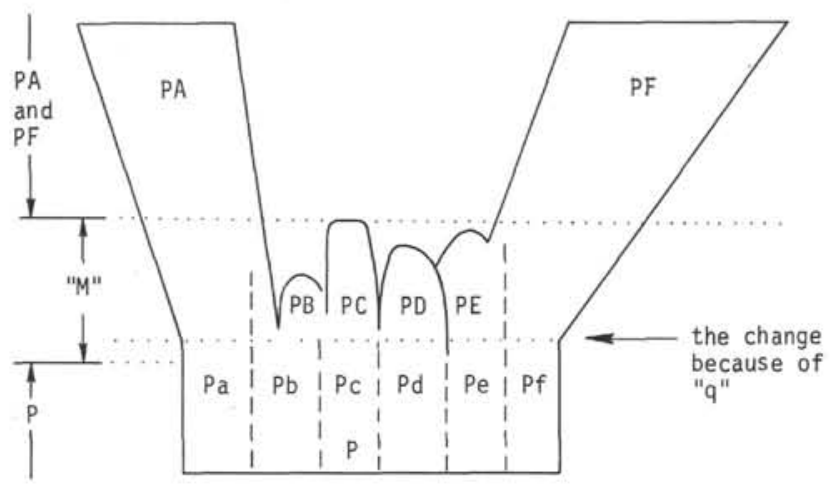

Figure 3. Divergence of the characters of the parent species.

daughter-species are more individualized, a differentiation between them and the ancestral species as quite easy to determine. The determination of the temporal limit of the species "P" and "PA" and "PF" is also possible, although on a comparatively larger temporal scale (approximately time period "M"). The determination of such a period is not difficult, provided that all of the species are sufficiently numerous.

However, cases are completely possible, when a species remains (upon having appeared) rather small in number until such time as its numerical strength begins suddenly to increase (Species A, Figure 4). The increase continues up to the time when the other species (Species

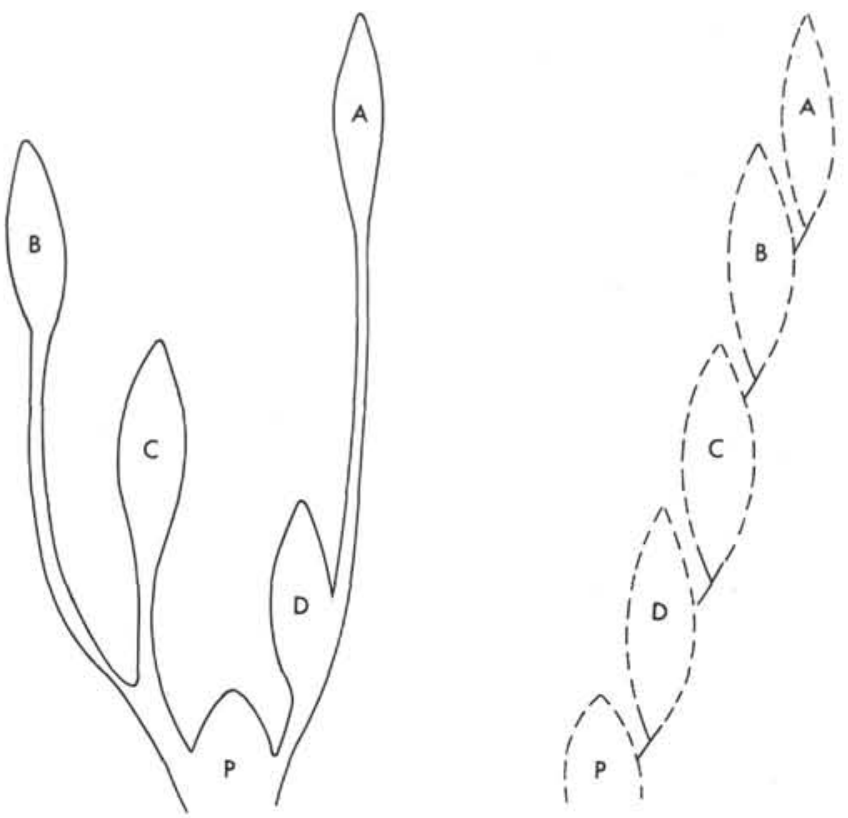

Figure 4. Alternate phylogenies for species $A$ and $B$.

B, Figure 4), which is a food competitor of Species A, becomes extinct. Species B might disappear not only because it is forced out by Species A, but also because of changes in temperature and salinity. In this case Species B is unable to adapt in contrast to Species A which can adapt easily. Consequently, when studying their remains in bottom sediments, one gets the impression that Species A originated much later than it actually did (i.e., at the moment when it became more numerous). If, in addition, Species A and B are morphologically close, it might appear that Species A derived from Species B, whereas in fact they might have a more of less distant common ancestor. The author believes that such cases were most frequent during the evolution of new taxa of polycystine radiolarians. Upon investigation of a great number of samples, single specimens of a morphological form which usually occurs in recent layers can be also discovered in more ancient ones. An example of this can be found with Clathrocyclas bicornis Popofsky.

\section{Geographic Distribution of Individual Species}

Determining the geographical distribution of the individual species is of primary importance, since the zone which has been marked by the name of some species can be traced within the range of the distribution of this species. The problems of the geographical distribution of radiolarians, the importance of the definition of subspecies, etc., has been dealt with in detail by Riedel (1973). However, it is important to note that a once widely distributed species can, with change of the hydrological regime, also change its area of distribution (Figure 5). This is exemplified by Saturnalis circularis and Pterocanium trilobum, which were suggested by Hays (1965) as indicator-species of Zone $\chi$ in subantarctic sediments. It was found (Petrushevskaya, 1971a, b; Petrushevskaya and Linjkova, 1972) that in S. circularis 

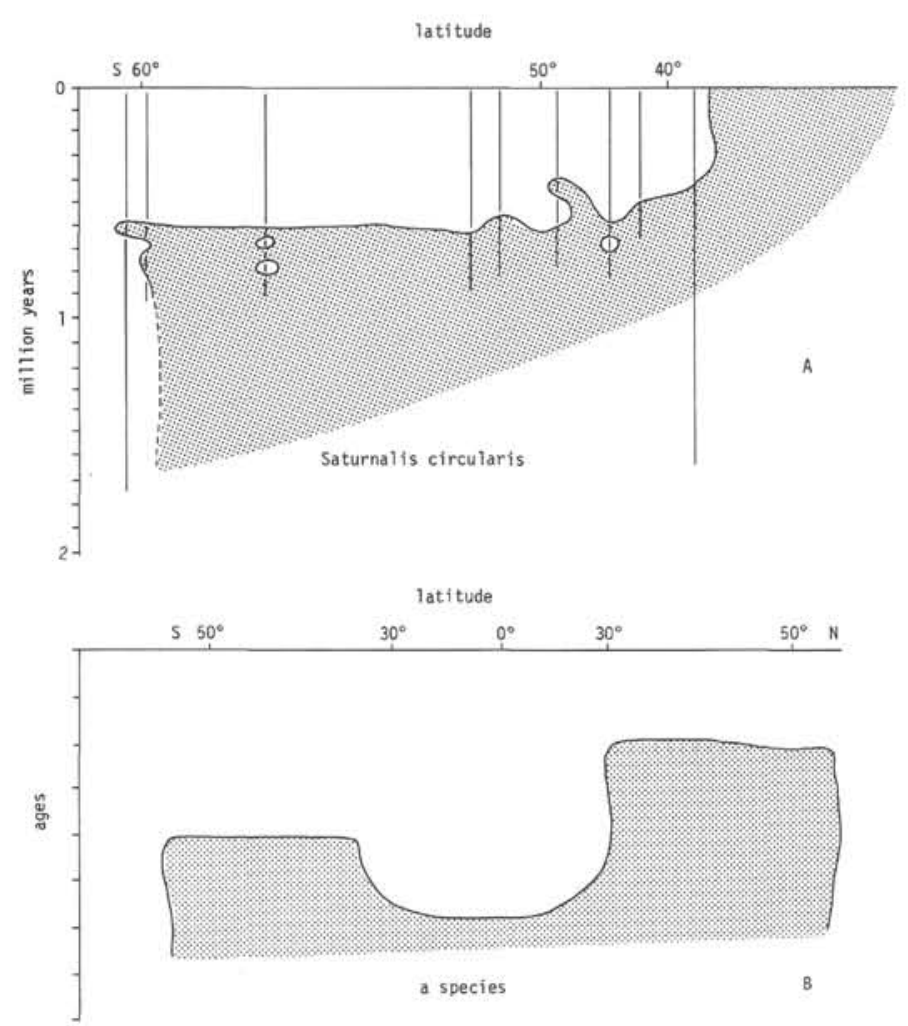

Figure 5. Area of distribution of Saturnalis circularis (vertical lines represent cores investigated).

and possibly in P. trilobum, the area of distribution was narrowed considerably during the Pleistocene (Figure $5 \mathrm{~A})$. Thus, the definition of stratigraphic zones by such species is extremely difficult.

The above examples are obviously not unique. There is reason to believe that in a more distant era (Oligocene, early Miocene), areas of the Antarctic represented an extraordinary refuge for relics of the Eocene fauna. Thus, the typical Amphymenium splendiarmatum Clark and Campbell is widely represented in the Eocene deposits of the tropics (Sanfilippo and Riedel, 1973); in the Antarctic, a very closely related morphological form (Plate 7, Figure 1) survived right to the middle of the Miocene.

In reference to the species or species groups of Polycystina which presently inhabit the Antarctic, it can, in the case of Spongodiscus resurgens, Stylodictya stellata group, Artostrobus annulatus, Lithomitra arachnea, Cyrtolagena laguncula, Cornutella profunda, Diplocyclas bicorona group, and Peripyramis circumtexta (Plate 5) be assumed with certainty that these taxa existed since the early Miocene. During the Miocene they were widely distributed not only in the Antarctic but also in the central Atlantic and California (Campbell and Clark, 1944a, b; Petrushevskaya, 1969a, b; Petrushevskaya and Kozlova, 1972). Presently they are generally widely distributed. However, objections might be raised (when speaking of groups of species), that the systematics of this group are not sufficiently developed, and that at the present time the various areas of the world's oceans are inhabited by various species and subspecies of each of these species groups. However, there are among these taxa very distinet units (Artostrobus annulatus, Cyrtolagena laguncula). It can be assumed almost with certainty that they correspond to the present biological species. The long period of their existence (since the middle or even early Miocene) can be explained by the fact that they are inhabiting abyssal waters, where the hydrological conditions are comparatively stable; it can also be due to the predominance of agamous reproduction, which does not yield great possibilities for the development of forms. However, the present wide distribution of these species can obviously be ascribed only to their inhabiting deep waters.

The other of the present living species: Antarctissa strelkovi, Triceraspyris antarctica, Lithelius? nautiloides, Lithamphora furcaspiculata typ., Schizodiscus favus maxima, Spongurus? pylomaticus, and Saccospyris antarctica are at the present time endemic to the Antarctic. Some of these species became characteristic of the middle Miocene in the Antarctic (Lithelius? nautiloides), others of the late Miocene (Lithamphora furcaspiculata, Schizodiscus favus maxima), and some (Spongurus? pylomaticus, Saccospyris antarctica) of the Pliocene.

The probable ancestors of some of these presently living species, can be defined: Ceratocyrtis sp. " $\mathrm{r}$ " for $\mathrm{An}$ tarctissa strelkovi; Lithelius? nautiloides form "p", for L.? nautiloides; Lithamphora sp. aff. L. corbula (Harting) for L. furcaspiculata, and Saccospyris preantarctica for $S$. antarctica. In all cases, the ancestral and daughter species existed simultaneously in one area, followed by the extinction of the ancestral species. Evidence of the divergence, as well as of the appearance of two daughter species, could be noted only at the formation of Lithamphora furcaspiculata, i.e., in a form ancestral not only to $L$. furcaspiculata but also to $L$. corbula typ.

\section{DATA ON EVOLUTIONARY LINEAGES}

In the brief summary of data to follow, brief mention will be made of the history of the species (morphological groups?). In some cases there obviously occurred substantial changes, which led to the formation of new species(?) or morphotypes. Most of the taxa have not been described yet and do not have binomial names.

In the Cenosphaera cristata group, the Miocene individuals (form "B") had very delicate inner spheres (first shell); then the skeletal sphere was reduced, which led to the formation of the typical $C$. cristata.

In the Stylosphaera hispida Ehr. group, some outer radial spines (nonpolar) were reduced in the latest Miocene. The taxonomic status of the various forms of this species group still has to be investigated.

In the Lithelius? nautiloides group, the form "P" had a larger, elongated skeleton covered with a "mantle". In the descendant form L.? nautilus typ., the outermost parts of the skeleton (and the "mantle") are reduced (Plate 3, Figures 1, 3, and 5).

In the Amphymenium? splendiarmatum group, the spongy meshes in the distal ends of the arms were more numerous in Antarctic early Miocene specimens than in the Eocene-Oligocene specimens. 
In the lineage

Artostrobus sp. Cr. $<$ A.?pretabulatus $\rightarrow$ pusillum annulatus, not only did the cephalis increase (elongate), but there was also an elongation of the upper part of the thorax and the formation of a "pedestal."

In the lineage

Gondvanaria sp.

(Plate 25, Figure 5) ?-Dictyophimus hirundo (2), there is a tendency toward a decrease of appendages (1), and perhaps a diminishing of appendages (2).

In the Lychnocanella conica group, the Oligocene specimens were larger and their cephalis globular. The Miocene specimens were smaller, with cephalis set on a "pedestal."

In the Lithamphora sp. aff. L. corbula $<L$. corbula typ. (1) lineage, different tendencies were observed: (1) in the tropic specimens stabilization in the segment shape and pore distribution; (2) in the Antarctic, more advanced, thinner shells of irregular outline and pores.

In a large species group (in this paper referred to as the Anthocyrtella kruegeri group), the Oligocene-early Miocene specimens had multisegmented shells (see Petrushevskaya and Kozlova, 1972, pl. 25, fig. 3). The skeleton of the late Miocene-Quaternary individuals consists of only two to three segments.

In the Ceratocyrtis sp. " $\mathrm{r}$ " $\rightarrow$ Antarctissa strelkovi lineage, a reduction in the thorax length and an elongation of the eucephalic lobe seems to have taken place.

In the Desmospyris rhodospyroides $\rightarrow D$. spongiosa lineage, the walls of the shell become thick, the pores increase in number, their distribution becomes less regular, and the surface becomes spongy.

In the Saccospyris preantarctica $\longrightarrow S$. antarctica lineage, the skeletons become larger, the walls thicker, and the appendages weaker.

\section{Questionable Evolutionary Changes}

\section{Lithelius? foremanae group $\rightarrow$ ? L. nautiloides form} "p."

Pylospira sp. A $\rightarrow$ ? Phorticium clevei (by reduction of part of the external skeletal latticed plates).

Lithocarpium sp. aff. L. monikae (Plate 4, Figures 610)-

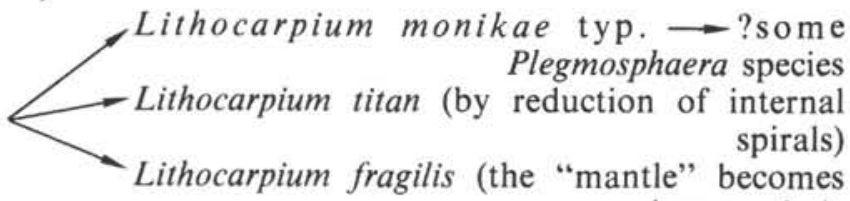
less regular).

The lineage (partly indicated by Sanfilippo and Riedel, 1973) Stylotrochus? alveatus Sanfilippo and Riedel-? -Porodiscus? charlestonensis Clark and Campbell-? $\rightarrow P$. bergontianus Carnevale-? $\rightarrow$ P.? circularis Clark and Campbell-? $\rightarrow$ Trematodiscus? ellipticus Stöhr-? $\rightarrow$ T.? microporus Stöhr. Here, an increase in the size of the central meshes (chambers) and a reduction in their number seem to take place.

In the Xiphospyra ocellata-? $\rightarrow X$. splendes-? -Stylodictya gracilis-? $\rightarrow$ Stylodictya stellata group lineage, an increase in the number of chambered rings and a reduction in the size of meshes (chambers) might have taken place.

In the lineage of segmented Paleocene Cyrtophormis sp. Ch. (Plate 8, Figures 16, 22)-? -Stichopodium saccoi $-? \rightarrow S$. calvertense $-?-S$. biconicum and the other multisegmented Miocene Stichopodium species, various patterns of segmentation of the postthoracic part of the shell might have occurred.

In the lineage of Thyrocyrtis bromia-? -Androcyclas heteroporous and some Lamprocyclas species described by Kling (1973) - ? $\rightarrow$ Androcyclas gamphonychos, there seemingly occurred an elongation of the cephalis and the development of its lateral lobes.

In the multisegmented lineage Clathrocyclas sp. aff. C. nova (Plate 15, $\longrightarrow \longrightarrow$ C. universa group (1)

Figure 17) $-? \longrightarrow$ C. titanothericeraos (2), a reduction in the number of segments, and (2) the development of the Vert-horn might have taken place.

In the lineage

Ceratocyrtis sp. aff. C. cucullaris $-? \rightarrow$ C. amplus -? -Ceratocyrtis $\mathrm{sp}$. " $\mathrm{r} "-$ Antarctissa strelkovi. - Antarctica clausa

various tendencies might have developed.

In Antarctissa capitata $-? \rightarrow$ A denticulata lineage, the walls might have thickened.

\section{RADIOLARIAN STRATIGRAPHY}

The time of the first appearance of new species among fossil remains, the period of simultaneous existence of the daughter and ancestral species, and the time of a complete disappearance of the ancestral species are (as far as can be judged by the studied sections) rather extensive periods. Tables 3-7, the sections corresponding to those periods of time have a hachured symbol. In order to substantiate stratigraphic boundaries, not only were frequently lengthy evolutionary changes in the radiolarian fauna used but also the appearance or disappearance of other species (morphotypes) in the skeletal sediments. For the latter, the history of the evolution is so far completely unclear.

It should be noted that the species characteristic for the upper Miocene and Pliocene deposits in the tropics, and used mostly as age indicators of these deposits, were not encountered any farther south than the Polar Front area. This has been shown by Petrushevskaya (?1973) for Stichocorys peregrinus and Pterocanium prismatium, as well as for some other species in the present article. In the deposits of higher latitudes, otherwise well studied species still cannot be identified with certainty. Therefore, a stratigraphic correlation of the Miocene deposits investigated from the Antarctic with the more thoroughly studied tropical faunas is rather difficult. It is, however, feasible to assume that the stages of the development of the climatic aspects of the earth had an equal effect upon the development of radiolarians in the tropics as well as upon those in the higher latitudes of the southern hemisphere. In the sediments of the middle-upper and upper Miocene of the Antarctic, sharp and extremely frequent changes are noticeable, which probably correspond to five or even six "radiolarian zones" (Stichocorys peregrinus, Ommatar- 
TABLE 1

Radiolarian Events Used to Establish Radiolarian Zones at DSDP Leg 29, 256; and Eltanin 14-8 Sites

\begin{tabular}{|c|c|c|c|c|c|c|c|c|}
\hline \multirow[b]{2}{*}{ Zone } & \multirow[b]{2}{*}{ Radiolarian Events } & \multicolumn{4}{|c|}{ DSDP Leg 29} & \multirow{2}{*}{$\begin{array}{l}\text { Eltanin } \\
14-8 \\
13-17\end{array}$} & \multicolumn{2}{|c|}{$O b$} \\
\hline & & $280 \mathrm{~A}$ & 281 & 278 & 280 & & 256 & 268 \\
\hline & $\begin{array}{l}\text { Actinomma buspinigera (Hays) (top) } \\
\text { Stylosphaera hispida Ehr.= } \\
\text { Stylatractus universus Hays (top) } \\
\text { Perichlamidium sp. Q Petrush. (top) }\end{array}$ & & & & & $\Omega / \psi$ & & \\
\hline A & $\begin{array}{l}\text { Pylospira sp. L. florish } \\
\text { Antarctissa cylindrica Petrush. (top) } \\
\text { Actinomma tetrapyla (Hays) (top) } \\
\text { Saccospyris preantarctica np. (top) } \\
\text { Octodendron sp. Hays (top) }\end{array}$ & & $\begin{array}{l}4, \mathrm{CC} \\
\text { above? 3-5 }\end{array}$ & $\begin{array}{r}2-1 \\
-\overline{-} \\
2-1\end{array}$ & - & $\begin{array}{l}\gamma \\
\chi \\
\chi \\
\chi \\
\chi\end{array}$ & $640 \mathrm{~cm}$ & \\
\hline & $\begin{array}{l}\text { Clathrocyclas bicornis Hays (top) } \\
\text { Pterocanium prismatium Riedel (top) } \\
\text { Stichopodium biconicum (Vinassa) (top) }\end{array}$ & & $\begin{array}{l}3-2 \\
3-2\end{array}$ & $\begin{array}{l}5-6 \\
3-2\end{array}$ & $1-2$ & $\begin{array}{l}x / \phi \\
\chi \\
x / \phi\end{array}$ & & \\
\hline B & $\begin{array}{l}\text { Saccospyris antarctica Haecker (bottom) } \\
\text { Diplocyclas davisiana (Ehr). (bottom) } \\
\text { Spongurus pylomaticus Riedel (bottom) }\end{array}$ & & & $\begin{array}{l}7-4 \\
8-2 \\
7-6 \\
\end{array}$ & & & & \\
\hline & $\begin{array}{l}\text { Pseudocubus vema (Hays) (top) } \\
\text { Desmospyris spongiosa Hays (top) } \\
\text { Ommatodiscus haeckeli Stohr } \\
\text { (becomes untypical, dense or hollow) } \\
\text { Stichororays peregrinus (Riedel) (top) } \\
\text { Androcyclas heteroporus (Hays) (top) } \\
\text { Lychocanium grande Campbell and Clark (top) }\end{array}$ & & $\begin{array}{l}6-3 \\
3-2 \\
3, \mathrm{CC}\end{array}$ & $\begin{array}{l}8-5 \\
8-5 \\
\\
16-3\end{array}$ & below 1-2 & $\begin{array}{l}\phi / \gamma \\
\gamma \\
\gamma\end{array}$ & & ? \\
\hline & $\begin{array}{l}\text { Clathrocyclas cabriloensis } \\
\text { Campbell and Clark (top) } \\
\text { Perichlamidium sp. Q (bottom) } \\
\text { Antarctissa cylindrica n. sp. (bottom) } \\
\text { Oroscena "digitate" Friend and Riedel (top) } \\
\text { Gondvanaria japonica (Nakaseko) (top) } \\
\begin{array}{l}\text { Calocyclas ?redondoensis (Campbell } \\
\text { and Clark) (top) }\end{array} \\
\end{array}$ & & Below 3, CC & $\begin{array}{l}9-3 \\
2-1 \\
9-3 \\
9-3\end{array}$ & & $\begin{array}{l}\gamma / \Upsilon \\
\gamma / \Upsilon\end{array}$ & & \\
\hline $\mathrm{v}$ & $\begin{array}{l}\text { Stichopodium inflatum (Kling) } \\
\text { is present } \\
\text { Astrompos Antkpenultimus } \\
\text { is present } \\
\text { Heliodiscus sp. } \\
\text { is present } \\
\text { Lychnocanium sp. C } \\
\text { is present } \\
\text { Haliommetta miucenica } \\
\text { (Campbell and Clark) florish }\end{array}$ & & $\begin{array}{l}\text { from } 6-3 \\
\text { to } 4, C C \\
5-2 \\
\text { from } 4, C C \\
\text { to } 3-5\end{array}$ & $\begin{array}{l}\text { from } 11-1 \\
\text { to } 9-5 \\
\text { from } 11-5 \\
\text { to } 10-1 \\
\text { from } 11-6 \\
\text { to } 10-1\end{array}$ & $\begin{array}{l}\text { from } 1, C C \\
\text { to } 1-4\end{array}$ & $\Upsilon$ & & \\
\hline & $\begin{array}{l}\text { Botryometra poljanskii n. sp. } \\
\text { is present } \\
\text { Desmospyris rhodospyroides n. sp. (top) } \\
\text { Botryopyle sp. A (top) } \\
\text { Lithocarpium polyacantha (Campbell } \\
\text { and Clark (become dense, untypical) } \\
\text { Clathrocyclas humerus } \mathrm{n} \text {. sp. (top) } \\
\text { Lithocampe subligata (Stohr) (top) } \\
\text { Lithocarpium fragilis (Stohr) (top) }\end{array}$ & $2, \mathrm{CC}$ & $9, \mathrm{CC}$ & $\begin{array}{l}\text { from } 12-3 \\
\text { to } 10-6 \\
10-6 \\
10-6 \\
\text { above } 10-6 \\
\\
11-1 \\
17-5 \\
11-2\end{array}$ & $\begin{array}{l}\text { below 1-2 } \\
1-2 \\
1-2\end{array}$ & $\begin{array}{l}\stackrel{\Upsilon}{\Upsilon} \\
\stackrel{\Upsilon}{\Upsilon}\end{array}$ & & \\
\hline & $\begin{array}{l}\text { Cricodiscus ellipticus (Stoht) (top) } \\
\text { Lithocampe (Cyrtocapsella) } \\
\text { Comiesse is present }\end{array}$ & & $\begin{array}{l}\text { from } 9, \mathrm{CC} \\
\text { to } 5-1\end{array}$ & $\begin{array}{l}11-4 \\
\text { from } 12-1 \\
\text { to } 11-6\end{array}$ & $1 \mathrm{CC}$ & $\Upsilon$ & & \\
\hline
\end{tabular}


G

\begin{tabular}{|c|c|c|c|c|c|c|c|}
\hline $\begin{array}{l}\text { Astromma hughesi (Campbell and } \\
\text { Clark) is present }\end{array}$ & & $\begin{array}{l}\text { from } 8-6 \\
\text { to } 7-3\end{array}$ & & & & & \\
\hline $\begin{array}{l}\text { Sponguridae gen. sp. } \\
\text { is present } \\
\text { Actinomma golownini } \mathrm{n} \text {. sp. (top) } \\
\text { Antarctissa robusta } \mathrm{n} \text {. sp. (top) }\end{array}$ & & above $9-3$ & $\begin{array}{l}\text { from } 13-6 \\
\text { to } 12-1 \\
12-1 \\
12-2\end{array}$ & $\begin{array}{l}1, \mathrm{CC} \\
\text { from } 1, \mathrm{CC} \\
\text { to } 1-2\end{array}$ & $\Upsilon$ & atyp & \\
\hline $\begin{array}{l}\text { Circodiscus microporus (Stohr) (top) } \\
\text { Astromma petterssoni (Riedel) is present }\end{array}$ & & $\begin{array}{l}9-3 \\
9, \mathrm{CC}\end{array}$ & $12-6$ & & & & \\
\hline $\begin{array}{l}\text { Botryopera deflandrei } \mathrm{n} \text {. sp. (top) } \\
\text { Clathrocyclas titanothericeraos } \\
\text { (Campbell and Clark) (top) }\end{array}$ & & & $\begin{array}{l}14-1 \\
14-1\end{array}$ & & $\Upsilon$ & & \\
\hline $\begin{array}{l}\text { Schizodiscus codrant } \mathrm{n} \text {. sp. } \\
\text { is replaced by Sch. disymmetricus } \\
\text { Dogel and by Sch. favus var. maxima } \\
\text { Popofsky } \\
\text { Spongodiscus craticulatus (Stohr) } \\
\text { group (top) } \\
\text { Anthocyrtella kruegeri (Popofsky) } \\
\text { atyp (top) } \\
\begin{array}{l}\text { Cannartus laticonus } \text { Riedel } \\
\text { is present }\end{array}\end{array}$ & & & $\begin{array}{l}14-3 \\
14-4 \\
15-1 \\
\text { from } 15-6 \\
\text { to } 15-1\end{array}$ & & & & \\
\hline $\begin{array}{l}\text { Desmospyris haysi } \mathrm{n} \text {. sp. (top) } \\
\text { Botryostrobus euporus (Ehr.) florished } \\
\text { Lithamphora corbula (Harting) } \\
\text { spp. group gave rise to } \\
\text { L. furcaspiculata Popofsky } \\
\text { Lithocampe punctata (Stohr) (top) }\end{array}$ & & atyp 3.2 & $\begin{array}{l}16-4 \\
15-5 \\
15-4\end{array}$ & $\begin{array}{l}1, \mathrm{CC} \\
1-4 \\
\end{array}$ & $\Upsilon$ & $1033 \mathrm{~cm}$ & $115 \mathrm{~cm}$ \\
\hline Theocorys longithorax n. sp. (top) & & $11 \cdot 2$ & $16-4$ & & & & \\
\hline $\begin{array}{l}\text { Lithocampe (Cyrtocapsella) compacta } \\
\text { (Haeckel) (top) } \\
\text { L. (Cyrtocapsella) cylindroides } \\
\text { (Principi) (top) } \\
\text { Artostrobus pretabulatus n. sp. (top) }\end{array}$ & & $\begin{array}{l}11-2 \\
8, \mathrm{CC}\end{array}$ & $\begin{array}{l}17-2 \\
18-3 \\
18-3 \\
\end{array}$ & & & $\begin{array}{r}1074 \\
\text { no45 } \\
\end{array}$ & \\
\hline $\begin{array}{l}\text { Artocyrtis punctatus (Ehr.) typ } \\
\text { is present } \\
\text { A. punctatus forma E } \\
\text { is present }\end{array}$ & & $\begin{array}{l}\text { from } 11 . C C \\
\text { to } 11.2\end{array}$ & $\begin{array}{l}\text { from } 20-3 \\
\text { to } 19-2\end{array}$ & & & & \\
\hline $\begin{array}{l}\text { Clathrocyclas bicornis Hays (bottom) } \\
\text { Stichopodium biconicum (Vinassa) gr. } \\
\text { (bottom) } \\
\text { Lithelius nautiloides Forma P (top) } \\
\text { Gondvanaria dogeli Petrush (bottom) }\end{array}$ & $4, \mathrm{CC}$ & $9, \mathrm{CC}$ & $\begin{array}{l}20-4 \\
20-4 \\
20-6 \\
20-6 \\
\end{array}$ & & $\Upsilon$ & & 115 \\
\hline $\begin{array}{l}\text { Clathrocyclas titanothericeraos } \\
\text { Campbell and Clark (bottom) } \\
\text { Amphymenium? spledriarmatum } \\
\text { Clark and Campbell atyp (top) } \\
\text { Desmospyris spongiosa Hays (bottom) }\end{array}$ & above $2-2$ & & $\begin{array}{l}21-6 \\
21-6 \\
21-6 \\
\end{array}$ & & & & \\
\hline $\begin{array}{l}\text { D. haysi n. sp. (bottom) } \\
\text { Lithocampe (Cyrtocapsella) cylindroides } \\
\text { (Principi) (bottom) } \\
\text { Antarctissa strelkovi Petrush. (bottom) }\end{array}$ & & $\begin{array}{l}6, \mathrm{CC} \\
\text { Below? } \\
12, \mathrm{CC}\end{array}$ & $\begin{array}{l}22-1 \\
22-1 \\
22-3\end{array}$ & & & & \\
\hline
\end{tabular}


TABLE 1 - Continued

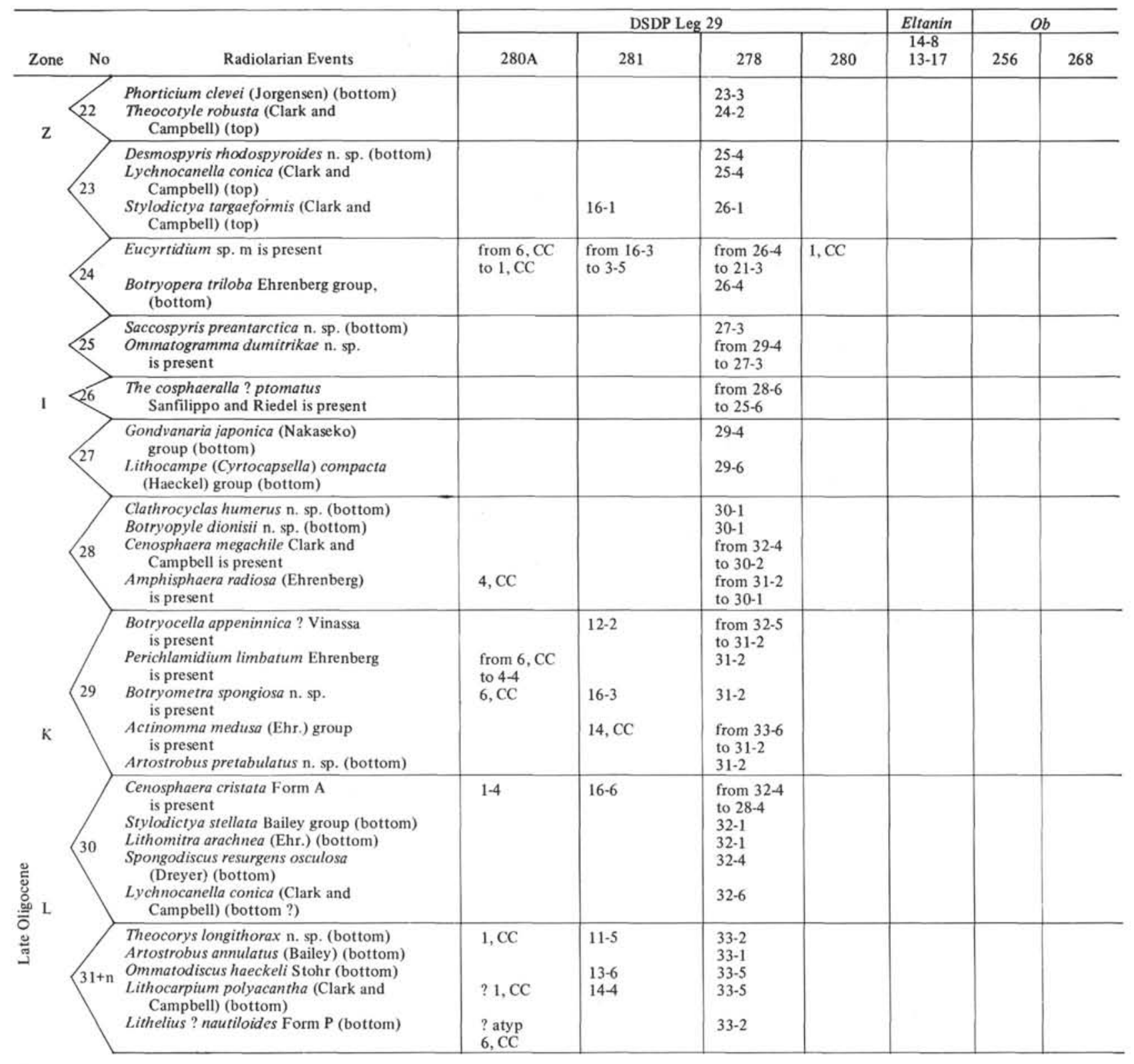




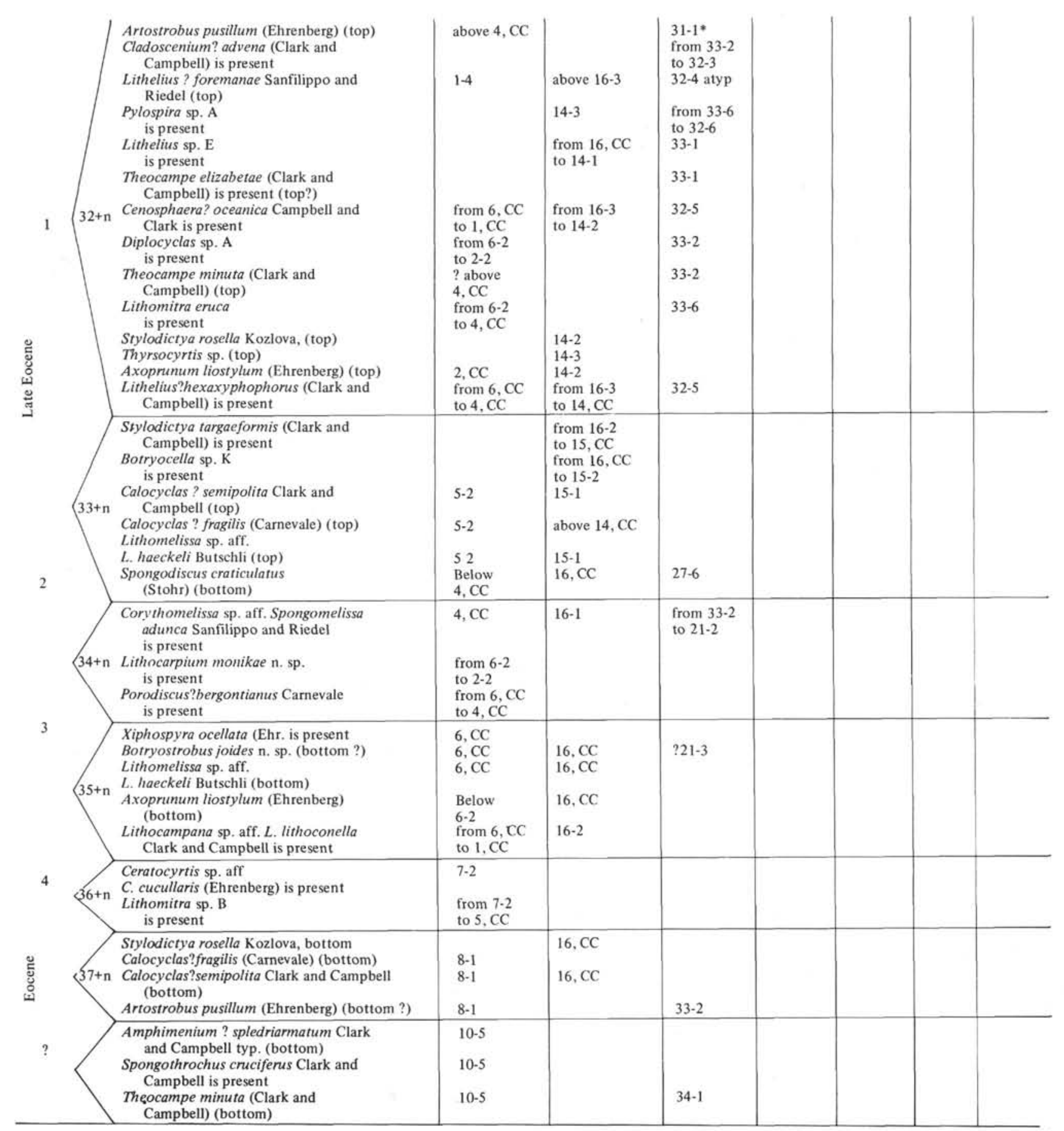


tus penultimus, $O$. antepenultimus, Cannartus petterssoni and $C$. laticonus) in the tropics.

Conversely, the sediments of the lower Miocene (the accumulation of which took twice as much time) the changes of the radiolarian fauna the Antarctic are less sharply expressed and less frequent. Apparently, this corresponds to one "radiolarian zone" with Calocycletta virginis (or, more precisely, $C$. veneris?) and, partly to the zones with Calocycletta costata and Lychnocanium bipes. More ancient Eocene deposits are probably easier to correlate.

Since the number of sections studied in the Antarctic is rather small, it is difficult to decide how synchronous the established periods of change of the radiolarian fauna are, and in what geographical ranges they occurred. Thus the author refrains from establishing such "radiolarian zones" which are customarily used in the reports of the Deep Sea Drilling Project.

Table 1 contains a list of events in the development of the radiolarian fauna which were noticed in the samples studied. Those events which seem to be synchronous are united under a single number. In essence, each number shows the substantiation of the boundary of a certain stratigraphic horizon; however, the significance of the individual boundaries is unequal. The most distinctly outlined horizons and their specific peculiarities are isolated as tentative zones and marked by letters. Table 2 compares those zones and events with the stratigraphy of the DSDP Leg 29, Ob, and Eltanin sites.

\section{Zone A}

The sediments, the age of which is considered as less than 1.7-1.8 m.y. (Riedel et al., 1963; Hays et al., 1969; Riedel and Sanfilippo, 1970) are considered Quaternary. In tropical areas $\left(40^{\circ} \mathrm{N}\right.$ to $\left.40^{\circ} \mathrm{S}\right)$ the lower boundary of these sediments is marked, according to the data of these authors, by the disappearance of Pterocanium prismatium. It is also noteworthy that the skeletons of Pterocorys campanula disappear here and the typical Pterocorys hertwigii appear.

In the $1.7 \mathrm{~m} . \mathrm{y}$. old sediments of $50^{\circ} \mathrm{S}-60^{\circ} \mathrm{S}$ lat, the occurrence of Clathrocyclas bicornis Hays becomes discontinuous, whereas Saccospyris antarctica, Diplocyclas davisiana and Spongurus? pylomaticus (Petrushevskaya, ?1973, and present article) become more numerous. Species common to the sediments of both high and low latitudes (the time-range of which would be confined to a specific period) could not be discovered.

In the Quaternary deposits, there was success in determining in the tropics (Nigrini, 1971; Petrushevskaya, ?1972), as well as in high latitudes, three or even four stratigraphic horizons, characterized by various sets of Tertiary species about to become extinct. The radiolarian complexes in the uppermost of these horizons differ only slightly from the distribution of radiolarians in the surface layer of the Recent bottom sediments. The latter have been studied rather accurately. In the Antarctic deposits, such an uppermost horizon was marked by Hays (1965) as Zone $\Omega$, whereas Petrushevskaya (?1972) marked it as Horizon I. Its isolation into an independent zone is hardly justified, since no species has been discovered which existed only in the last 400,000 yr (approximate age of the first horizon), in spite of the fact that the sediments of this age were quite adequately studied.

Within the range of Quaternary Antarctic deposits, Hays additionally isolated the Zones $\Psi$ and $\chi$. It is Hays' opinion that the boundary between these zones is characterized by the disappearance of Saturnalis circularis (which occurs lower) and Pterocanium trilobum (the content of which according to Hays is not always completely clear). However, as has been shown by Petrushevskaya (1971c) and Petrushevskaya and Linjkova (1972), these species gradually narrowed their area of distribution and the area where they ceased to exist just $600,000 \mathrm{yr}$ ago is rather narrow (Figure 5). Therefore, the zonal boundary $(\Psi / \chi=600,000 \mathrm{yr})$ can be defined only in very few Antarctic (more accurately, subantarctic) cores. The present author refrained from isolating Zones $\Psi$ and $\chi$ in the Antarctic sediments, but instead suggested (Petrushevskaya, 1972a) Horizons II and III, which are divided by the second event (see above). The second event is characterized by the extinction of several rather reliable species.

\section{Zone B}

In the tropics, the Quaternary sediments are underlain by the "zone with Pterocanium prismatium." The lower boundary is characterized by the disappearance of Spongaster pentas and Stichocorys peregrinus as well as by an increase in the number of Pterocanium prismatium.

In the deposits of the higher southern latitudes a zone is distinguishable which can be correlated with the zone with Pterocanium prismatium. The upper boundary of this Pliocene Antarctic zone is characterized by the disappearance of Clathrocyclas bicornis Hays (which is quite numerous in the lower boundary), and by the frequently almost synchronous disappearance of Stichopodium biconicum (usually mentioned as Eucyrtidium calvertense). In other words, the upper boundary of this zone is the boundary established by Hays (1965) for the Zones $\chi / \Phi$. The lower boundary of Zone B could be determined by the last occurrence of Prunopyle titan. Bandy et al. (1971) state that it is just this moment that marks the boundary between the Miocene and Pliocene of the Antarctic. However, $P$. titan has obviously been identified erroneously; the species referred to in this paper as Lithocarpium titan has never been encountered in the high latitude deposits, although Larcoidea (e.g., the extinct Pylospira sp. L) are rather numerous. Such events in the history of Larcoidea as the transition of Ommatodiscus haeckeli into an atypical form, and the complete disappearance of Lithocarpium polyacantha, are confined to the lower boundary of Zone B. Apparently, just these changes of the fauna were described as the extinction of L. titan. Lychnocanium grande and Androcyclas heteroporus usually also do not enter the zone, instead they occur (rather irregularly) below this zone. Desmospyris spongiosa and Pseudocubus vema might occur in the lower part of Zone B. On the whole, the lower boundary of Zone B (= Event 5) completely 
TABLE 2

Stratigraphic Columns with Foraminifera, Nannofossil, and Radiolarian Zones and Events at DSDP Leg 29, and Eltanin Sites

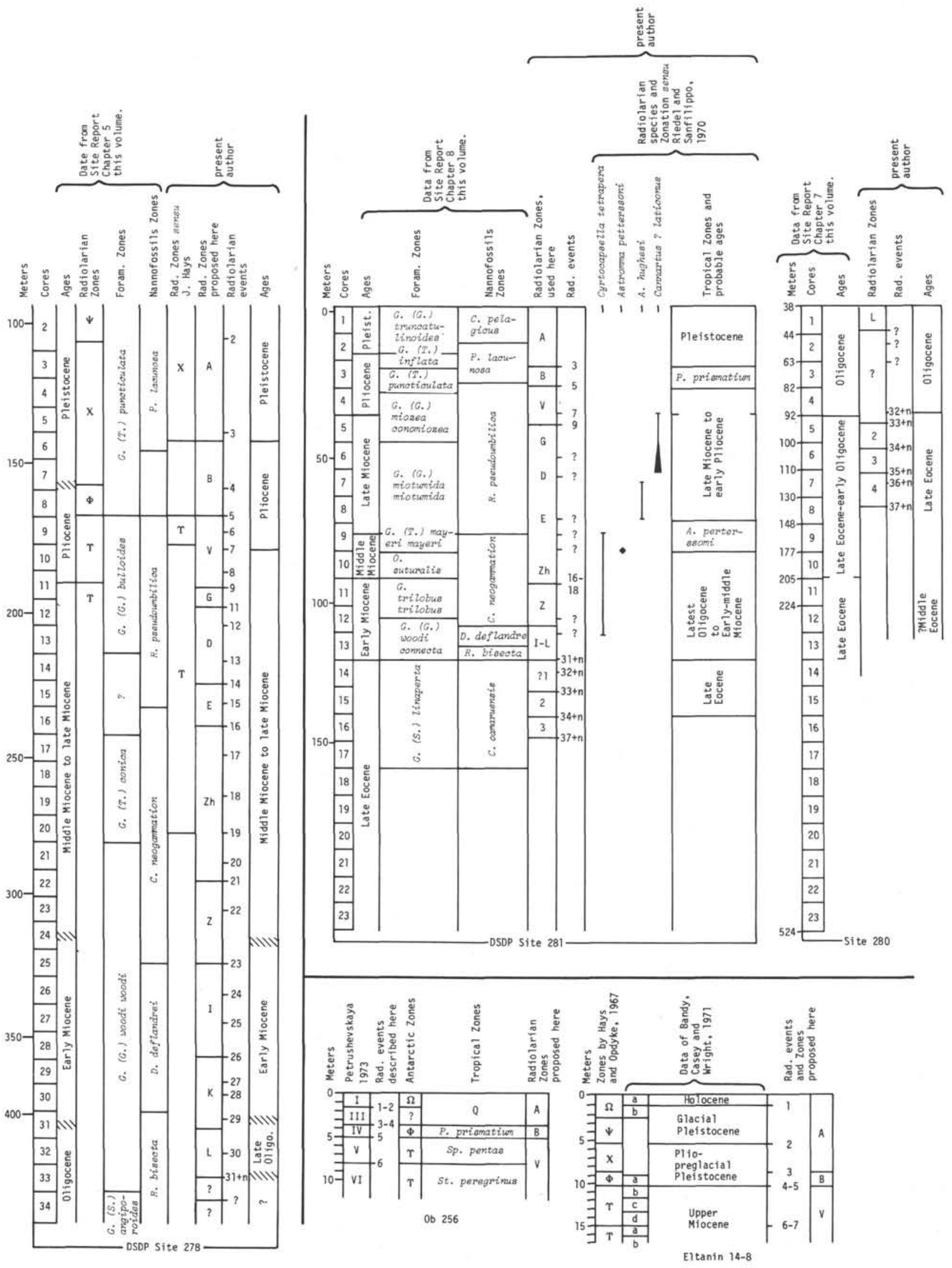


corresponds to the boundary of Zones $\Phi / \gamma$ established by Hays. Zone B in Antarctic sediments could be defined as "the zone with Clathrocyclas bicornis Hays" if: (1) this species would not occur much lower than the lower boundary of Zone B; and (2) if the name of this species would not be threatened by the nomenclature. An extremely close species, bicornis Popofsky, probably also belongs to the genus Clathrocyclas.

Zone B has been established at Site 278 (from Core 5, Section 3 to Sample 8, CC), and Site 281 (Core 3), as well as from many other cores (Table 2). It can also be traced in the deep-water deposits circumpolarly between $60^{\circ} \mathrm{S}$ and $40^{\circ} \mathrm{S}$ lat. (Figure 1).

It is interesting to note that skeletons of Pterocanium prismatium were encountered in the core of $\mathrm{Ob}$ Station 256 (although not in all samples) in this and the lower zones. Thus the correlation of Zone B and the zone with $P$. prismatium is confirmed (Petrushevskaya, ?1973a. It is possible, of course, that the lower part of Zone B also includes sediments which correspond to the "zone with Spongaster pentas". The latter species is extremely rare in the tropics, and it has not been found thus far at $40^{\circ} \mathrm{S}-50^{\circ} \mathrm{S}$ lat.

\section{Zone $\mathbf{V}$}

The upper boundary of this zone is given above (see Event 5 and Event 6 in Table 2). In the sediments at Site 278 (Cores 9-11), the zone is strongly characterized by the occurrence of Clathrocyclas cabrilloensis, Desmospyris spongiosa, Actinomma tetrapyla, Lychnocanium sp. C, Heliodiscus sp. and Stichopodium inflatum (Kling); however, it is hard to tell to what extent the latter species satisfy those requirements claimed for the zonal species. Therefore the author refrains from marking this zone by the name of any species.

The upper part of Zone V corresponds on the whole to Hays' Zone $\gamma$ (see Events 6 and 7 in Table 1). However, those species which were suggested earlier as indicators of the zonal boundary $\Upsilon / \gamma$ are not reliable: Cyrtocapsella tetrapera, Calocyclas? redondoensis, and Oroscena sp. digitate. Moreover, Calocyclas? redondoensis is so rare in all of the sediments studied of this age that they could be identified with certainty only in Eltanin Core E-14-8. In other coeval deposits are the last occurrences of the usually lower Gondvanaria japonica (Nakaseko), which resembles Calocyclas? redondoensis but differs, as has been shown by Nakaseko (?1970) quite distinctly from G. japonica.

A more sharply expressed boundary (the first occurrences of the usually higher Saccospyris preantartica, as well as the disappearance of the lower Desmospyris rhodospyroides, Clathrocyclas humerus, Lithocarpium fragilis, Stylosphaera sp. C. Circodiscus ellipticus, and Botryometra poljanksii [Events 8-9]) occurs lower, i.e., within the range of Hays' Zone T.

In the sediments of Zone V, Stichocorys peregrinus was constantly encountered in the core of $O b$ Station 256; it occurred lower than 8 meters (below Event 6) in great numbers, although Pterocanium prismatium was absent. This enabled us to correlate the sediments of the 5.0-7.8 meters horizon of this core (which corresponds to Hays' Zone $\gamma$ ) with the Spongaster pentas Zone, which Riedel isolated for the tropical deposits. The sediments of the 7.8-10.4 meter horizon in the core from $\mathrm{Ob}$ Station 256 (which are related to Hays' Zone T) were correlated with the Stichocorys peregrinus Zone (Petrushevskaya, ?1973).

Consequently, Zone V really corresponds in its upper and lower part to the Spongaster pentas Zone and (mainly) to the Stichocorys peregrina Zone.

In reference to Zone T, established by Hays, it should be noted that the zone encompasses most of the Antarctic sediments (Events 7 to 18). In the sediments of Zone $\mathrm{T}$ (in those cores of the R/V Eltanin, in which this zone has been established within the range of a few centimeters) the events are seemingly summarized. In the core from Site 278 these events are not only separated from one another by many tens of meters, but evidently also noncoeval. Thus, there arises the suspicion that the sediments of the lower layers of the cores in which Zone $\mathrm{T}$ was established were taken from an interrupted sequence (Table 2).

In the sediments taken at DSDP Site 281 which are related to the lowermost part of Zone V and, obviously, to Zone G (below Event 7), Ommatartus? laticonus was found as well as single specimens of Cyrtocapsella japonica. It seems probable that the lower part of Zone $\mathrm{V}$ should be correlated with the lower part of the $O$. antepenultimus Zone of tropical sediments.

The Miocene zones, $\mathrm{G}$ to $\mathrm{K}$, could be traced in their obviously sequential and almost uninterrupted occurrence only at Site 278 .

\section{Zone G}

This zone is characterized by the occurrence of Botryometra poljanskii, Circodiscus ellipticus, Cyrtocapsella japonica, and Heliodiscus sp., the distribution of which is, judging by the material of Site 278, approximately confined to this zone. The occurrence of Clathrocyclas cabrilloensis, Antarctissa robusta, and Lychnocanium sp. C. is also characteristic, but more widely distributed.

\section{Zone D}

Actinomma golownini and Sponguridae gen. sp. D are more or less restricted to Zone D. Within its range appear Clathrocyclas cabrilloensis and Circodiscus ellipticus. Botryopera deflandrei is common for the lower part of the zone, whereas Botryopyle sp. A occurs throughout the entire Zone D.

\section{Zone E}

This zone is characterized by the occurrence of $B$. deflandrei, Calocyclas sp. K, and Anthocyrtella kruegeri atyp. (the latter is confined exclusively to Zone E.) Botryopyle sp. A appeared first in this zone. It is interesting to note that at Site 278, Cannartus sp. aff. $C$. laticonus is confined to Zone E.

\section{Zone $\mathbf{Z h}$}

Clathrocyclas titanothericeraos and Dictyophimus archipilium are very characteristic for this zone, but not restricted to it. This also applies to Theocorys longithorax and Desmospyris haysi. The first appearance of 
some species coincides with the lower boundary of Zone Zh (Event 19).

\section{Zone $\mathbf{Z}$}

The upper boundary of the zone is Event 21 (appearance of some species). Characteristic for Zone Z are the Antarctissa capitata group and Stylosphaera sp. $\mathrm{C}$, but they are not restricted to the zone. The lower boundary is Event 23 when Botryopyle dionisii ceased to exist, and some species (Desmospyris rhodospyroides) appeared. The lower boundary coincides with the boundary between nannofossil zones $C$. neogammation/D. deflandrei (Table 2).

\section{Zone I}

Ommatogramma dumitrikai and Eucyrtidium sp. "m" are restricted to, and Ceratocyrtis sp. "r" is very characteristic of the zone. The lower boundary is Event 26 (where many species, in particular Gondvanaria japonica appear).

\section{Zone K}

The upper limit (Event 26) and the lower boundary (Events 29 and 30, where also Cystiphormis brevispina forma A, Theocotyle robusta, Amphisphaera radiosa, Lithocarpium fragilis appear and Schizodiscus codrant become numerous) are rather distinct, but it is difficult to indicate the species characteristic of or restricted to the zone. Within the zone Cyrtocapsella compacta, Clathrocyclas humerus, Botryopyle dionisii, Stylosphaera hispida, and some others appear or become numerous.

\section{Zone L}

The tops of Pylospira sp. A, Lithelius sp. E, Actinomma medusa, Artostrobus pusillum, Lychnocanella conica typ. are more or less restricted to this zone. The upper limit of the zone is Events 29 and 30. The lower limit in Site 278 is so sharp, that it seems possible that there is a coincidence of two or more events. This zone may belong in the upper Oligocene.

Oligocene sediments are present at Hole 280A, but radiolarians are rare. No species characteristic for the Oligocene radiolarian zones of tropical deposits (Theocyrtis annosa, Th. tuberosa, etc.) occur. The latter might be tropical species, and the environment at Hole $280 \mathrm{~A}$ in Oligocene might have been unsuitable for them. No radiolarian zonation can be proposed for high latitude Oligocene on the basis of the Leg 29 material.

Eocene sediments are present in Sites 280 and 281. No zonation is proposed, although no less than four zones are present at these sites (see Tables 1, 2). They still require thorough investigation.

The number of events is difficult to state, and the Eocene/Oligocene boundary is difficult to establish because (1) the upper limit of the Eocene deposits is very sharp in Sites 280 and 281, (2) radiolarians are rare in the sediment above at these sites. Perhaps the appearance of Ommatodiscus haeckeli typ. coincides with this limit. This species is common above, but absent in the Eocene. Characteristic are Axoprunum liostylum, Porodiscus? bergontianus, Theocampe minuta, Calocyclas? semipolita, C.? fragilis, Lithomitra sp. B, Litho- melissa sp. aff. L. haeckeli, Amphisphaera spinulosa, Lithelius? hexaxyphophorus, Thyrsocyrtis sp., Botryocella sp. K. It is difficult to decide which species are restricted to the zone. In the zone some events are distinct. They are the boundaries of the Zones 1, 2, 3, 4. On the whole the Eocene radiolarian assemblage of Leg 29 is rather similar to California (not Caribbean) Eocene.

\section{RADIOLARIANS OF LEG 29 SITES}

\section{Site 278}

Radiolarians are quite common to abundant at Site 278 except in Core 34 where they are rare and in Cores 35-37 where they are absent (Tables 3 and 4). As a rule, the skeletons are well preserved. There are thick-walled as well as thin-walled species. There is a great variety in the species composition, but few real tropical species. The distribution of over 150 species was traced.

The most recent sediments at 101-137 meters are related to the lower part of Zone A, which in the present article is correlated with Horizon III or to Zone $\chi$ of Hays, i.e., to the lower or middle (but not to the upper) Pleistocene. The Plio-Pleistocene boundary probably lies at approximately 137 meters (Core 5, Section 3), where Clathrocyclas bicornis Hays and Stichopodium biconicum disappear.

Pliocene sediments occur between 137 and 177 meters (Cores 6-9). This is Zone B and the upper part of Zone $\mathrm{V}$, which corresponds to Zone $\gamma$ (Table 2).

The probable Miocene-Pliocene boundary has been established at 177 meters (Core 9), where the usually lower Ommatodiscus haeckeli, Lithocarpium polyacantha, and Gondvanaria japonica disappear; therefore this boundary can be considered as corresponding to the boundary between Zones $\mathrm{T} / \gamma$, which is assumed as the Miocene/Pliocene boundary in Antarctic sediments.

The limit of the upper Miocene (the location of the lower boundary has been established by correlation with foraminiferal and nannoplankton zones) lies at approximately $177-230$ meters. These are radiolarian Zones D and G, and the lower part of Zone V. The middle Miocene deposits lie approximately at 230-315 meters subbottom. These are apparently Zones E, Zh and $Z$. Lower Miocene sediments (which were determined by correlation with foraminiferal and nannoplankton zones) occur at $310-400$ meters. These are Zones $\mathrm{I}$ and $\mathrm{K}$.

Oligocene radiolarian sediments can be encountered with certainty at $402-421$ meters. This is Zone L which corresponds to the upper Oligocene.

The changes in the radiolarian fauna observed at 415 420 meters are of a different character than the radiolarian events lying above (Table 1). In comparison with Sites 280 and 281 the changes which are observed here occur in a comparatively thin section although through a considerable length of time (Table 2). The corresponding events should mark several distinct stratigraphic zones. Thus the conclusion is reached that the sediments were not collected in perfect sequence. Consequently, the deeper layers containing radiolarians (Core 34) can be of a more ancient age than that established by foraminifera and nannoplankton, i.e., lower, not middle Oligocene. 
TABLE 3

Paleogene Radiolarian Species at Sites 278, (A); 280, (B); and 281, (C); DSDP Leg 29

\begin{tabular}{|c|c|c|c|c|c|c|c|c|c|}
\hline & \multicolumn{3}{|c|}{ A. Site 278} & \multicolumn{4}{|c|}{ B. Site 281} & \multicolumn{2}{|l|}{ c. Site 280 (Hole 280A) } \\
\hline $\begin{array}{l}\text { Theoconpe minuta } \\
\text { (Clark and Campbel1) group }\end{array}$ & $\because \cdots \bullet$ & & & & & & & 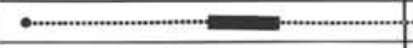 & $\cdots \cdot$ \\
\hline 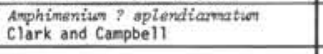 & & a..... & E...................・ & & & & & 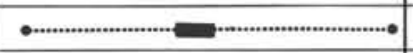 & \\
\hline Eithetiua sp. E. & - & & & $=$ & & & & & \\
\hline $\begin{array}{l}\text { Stylyadictya targaaformia } \\
\text { (Clark and Campoel1) }\end{array}$ & & $\bullet$ & & $=$ & & & & & \\
\hline Pyloopyra sp. A form B & & & & 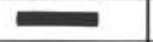 & & & & ○....................... & \\
\hline 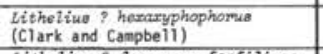 & $\bullet$ & & & $=$ & & & & $=$ & \\
\hline $\begin{array}{l}\text { titheliua ? forenanane Sanfilippo } \\
\text { and Riedel (typical form) }\end{array}$ & - & & & - & & & & .................. & - \\
\hline Artostrobus punillum (Ehrenberg) & - & 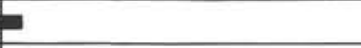 & & & & & & $a \cdots \cdots$ & \\
\hline $\begin{array}{l}\text { Cazacoyolas ? aenipotita } \\
\text { clark and Campbel1 }\end{array}$ & & & & $=$ & & & & 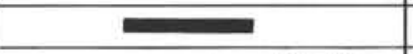 & \\
\hline Axoprumen liootilum (Ehrenberg) & & & $\bullet$ & $\longrightarrow$ & & & & 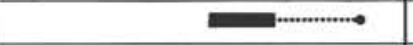 & \\
\hline $\begin{array}{l}\begin{array}{l}\text { Lithone tiesa sp. aff. } L \text {, hasokeli } \\
\text { Butschl1 }\end{array} \\
\end{array}$ & & & & $=$ & & & & 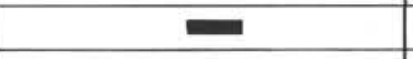 & \\
\hline Botryometra epongiosa $(\mathrm{n}, \mathrm{sp})$. & & - & & $\bullet$ & & & & $\bullet$ & \\
\hline $\begin{array}{l}\text { Cenosphaeena ? oceanioa } \\
\text { clark and Campbell }\end{array}$ & $\bullet$ & & & $=\cdots \cdots$ & & & & (.). & \\
\hline Diplooyelae sp. A & $\bullet$ & & & & & & & $\bullet \cdots \cdots+\cdots$ & \\
\hline $\begin{array}{l}\text { Lithaliun nenitilioides } \\
\text { Popof sky form p }\end{array}$ & $=$ & 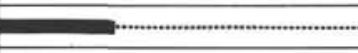 & ...........................・ & & & & & •atypical• & \\
\hline Eucyrtidion sp. M & & $\bullet$ & & & & & & $-\ldots$ & 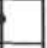 \\
\hline Botryostrobus joidea n. sp. & & & $\bullet$ & - & & & & $\bullet$ & \\
\hline 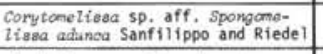 & - & & & $\bullet$ & & & & $\bullet$ & \\
\hline Amphiaphaersa radioas Ehrenberg & & 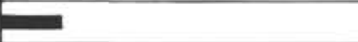 & & & & & & $\bullet$ & \\
\hline Spongodiesoue orationlatus (Stör) & & $-\ldots$ & ......................... & ………들 & & & & $\bullet$ & \\
\hline $\begin{array}{l}\text { Sporgodiocue ofroulario } \\
\text { clark and Campbell }\end{array}$ & & & & & & & & $\bullet$ & \\
\hline \multicolumn{10}{|l|}{$u$ thoosarpiven monikae n. sp. } \\
\hline $\begin{array}{l}\text { Clacioosoonitim ? advena } \\
\text { (Clark and Campbell) }\end{array}$ & $=$ & & & & & & & & \\
\hline Actinoma meduaa (Ehrenberg) group & 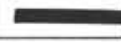 & & & $\bullet$ & & & & & \\
\hline $\begin{array}{l}\text { Lyohnowonelita conica } \\
\text { (Clark and Campbel1) }\end{array}$ & 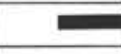 & $\bullet \rightarrow$ & & & & & & & \\
\hline $\begin{array}{l}\text { Botryoceltata, appeninnioa } \\
\text { vinassa group }\end{array}$ & 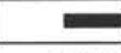 & & & & $\bullet$ & & & & \\
\hline Conouphaora orietata form A & ........... & - & & $\bullet$ & & & & & - \\
\hline \multicolumn{10}{|l|}{$\begin{array}{l}\text { Ceroospharana megachich } \\
\text { clark and Campbel1 }\end{array}$} \\
\hline Theocarys Longi thorax n. $\mathrm{sp}$. & ................ & . & $\ldots \cdots \cdots$ & & 붕 & & & & \\
\hline \multicolumn{10}{|l|}{ amatodiasue haeckeli Stöhr } \\
\hline Artos trobus pretabulatue n. $\mathrm{sp}$. & & $=$ & $\longrightarrow$ & & & & & & \\
\hline \multirow[t]{2}{*}{$\begin{array}{l}\text { Theocooph haere lla ptcmatus } \\
\text { Sanfilippo and Riedel }\end{array}$} & & $=$ & & & & & & & \\
\hline & 01 igocene & Early Miocene & Middle Miocene to late Miocene & Late Eocene & $\begin{array}{c}\text { Early } \\
\text { Miocene }\end{array}$ & $\begin{array}{l}\text { Middle } \\
\text { Wiocene }\end{array}$ & Late Miocene & Eocene | Oligocene & $\begin{array}{l}\text { Keo- } \\
\text { gene }\end{array}$ \\
\hline
\end{tabular}


Site 278 yields good material for the study of the history of the development of the Antarctic radiolarian fauna, and for the determination of the periods of appearance of Antarctic endemic species, extinct or living (Table 5). It is also interesting that at Site 278 skeletons of tropical Eocene species or closely related forms such as Thecosphaeraella? ptomatus, Amphymenium splendiarmatum group and others (Table 3) are encountered anomalously high. The occurrence of the Arachnocorallium calvata group, which is rather abundant in some of the recovered cores (Table 5), can be indicative of surface water warming in the area of the site during the early and late Miocene.

Disappearance, followed by a reappearance in higher sediments, has also been noted in other species. It was not possible to establish any morphological differences between the younger specimens and the geologically more ancient ones. Probably such "cycles" (as this phenomenon is called by some micropaleontologists) are due to changes of the areas of distribution of these species. These were caused by (thermal?) ecological conditions. In any case, there is reason to believe that the temperature of the surface water in the area of Site 278 during the deposition of the Oligocene-Pleistocene deposits was repeatedly subjected to considerable fluctuations. However, it was not possible to establish a causal relation between the change of climate and the evolutionary changes of the radiolarian fauna.

The peculiar composition of the fauna (initially the presence of the Antarctic endemic species with the beginning of the middle Miocene) leads to the conclusion that the principal factor which determined the development of radiolarians in the area of Site 278, was the hydrological isolation, which arose in connection with the system of the circumpolar circulation. The fluctuations in the position of the Antarctic convergence front, and the individual water masses (which were instrumental in the warming-up and cooling-off of the area of the site) did not have a major effect on the actual existence of a specific radiolarian fauna in the high latitudes of the southern hemisphere, beginning with the early Miocene. The radiolarians at Site 278 do not enable an evaluation of the earlier stages in the history of the Antarctic radiolarians.

\section{Site $\mathbf{2 8 0}$}

The site is in a geographical area which was most affected by the formation of the earliest stages of the circumpolar current when the South Tasmanian Ridge was separated from the Antarctic. Unfortunately, radiolarians were encountered only in the upper 10 cores (0-250 m subbottom). Thus, it was impossible to obtain any data on the first stages of the development of the Antarctic fauna (Tables 2, 3, and 6).

\section{Hole 280, Core 1}

At 1.75-6.0 meters cored sediments were typical for Zone $\mathrm{T}$ (presence of Ommatodiscus haeckeli and Lithocarpium polyacantha which obviously were formerly considered as Prunopyle titan). Thus, these sediments are not younger than the very lowermost Pliocene-upper Miocene. However, as has been shown in the description of the radiolarian zones, the lower boundary of Hays'
Zone $\mathrm{T}$ is indefinitely expanded, and a more accurate age determination by radiolarians is only possible by a correlation with the material at Site 278 (Table 2). The existence of Cyrtocapsella japonica, Antarctissa robusta, and Lychnocanium sp. C (characteristic of Zone G) simultaneously with the absence of species characteristic of other horizons, shows that these sediments should be related to Zone $\mathrm{G}$ of the present paper, and not to the uppermost Miocene. In the lowest sample there even appeared Actinomma golownini (which is typical for Zone D).

\section{Hole 280A}

The sediments from 40 to 44 meters (Core 1) contained radiolarians which, although of good preservation, were not numerous. The presence of Pylospira sp. A and Cenosphaera cristata form A gives reason to believe (see Table 1) that this core (as has been shown by other microfossils) is Oligocene. It is possible that these sediments should be related to Zone L (Table 6).

At 44.0-91.5 meters (Cores 2-4) the complex differs somewhat; such species as Lithocarpium monikae, Cenosphaera? oceanica and other large spherical skeletons are common, but usually the skeletons are few, and at about 75 meters they are rather poorly preserved. It is difficult to reach a conclusion regarding age. At 94-122 meters (Cores 5, 6) the radiolarians are abundant and well preserved. Two upper Eocene zones can be isolated here, namely Zones 2 and 3 (Table 1).

The 122-142 meters horizon (Core 7) differs somewhat in the composition of radiolarians from the upper complex of Zone 3: here, Lithocarpium monikae, Axoprunum liostylum, Lithocarpium polyacantha, Porodiscus? bergontianus, Lithomitra sp. B, and Lithomelissa sp. aff. L. haeckeli, which usually occur above, are missing. Probably these sediments should be isolated into a special zone, i.e., Zone 4, but the author is unable to give any characteristic species for it, or to substantiate its lower boundary. From 129.5 to 203.0 meters, the sediments (even if they do have radiolarian skeletons) contain only poorly preserved single specimens, frequently filled with clay. Thus it is impossible to establish any stratigraphic conclusions.

Core 10, Section 5 (at approximately $204 \mathrm{~m}$ ) contained poorly preserved skeletons, among which were identified: Cromyodruppa sp. Lipman (see Petrushevskaya and Kozlova, 1972, pl. 5 , fig. 14, 15) which were rather numerous, and Spongodiscus cruciferus and Stylosphaera minor, as well as Amphymenium splendiarmatum. This enables a correlation of this sample with the radiolarian zones isolated by Sanfilippo and Riedel (1973) for the Caribbean Basin, i.e., Phormocyrtis striata and even Buryella clinata zones. An earliest Eocene age can be assumed. In order to come to more accurate conclusions, it would be advisable to investigate not a specific sample, but a more complete section. Samples from 216 to 512 meters (Cores 12-23) did not contain radiolarian sediments.

\section{Site 281}

Studies at this site allowed a proposal that during the period of the late Eocene and Oligocene it was here that an intermingling of the upper water layers of the Indian 


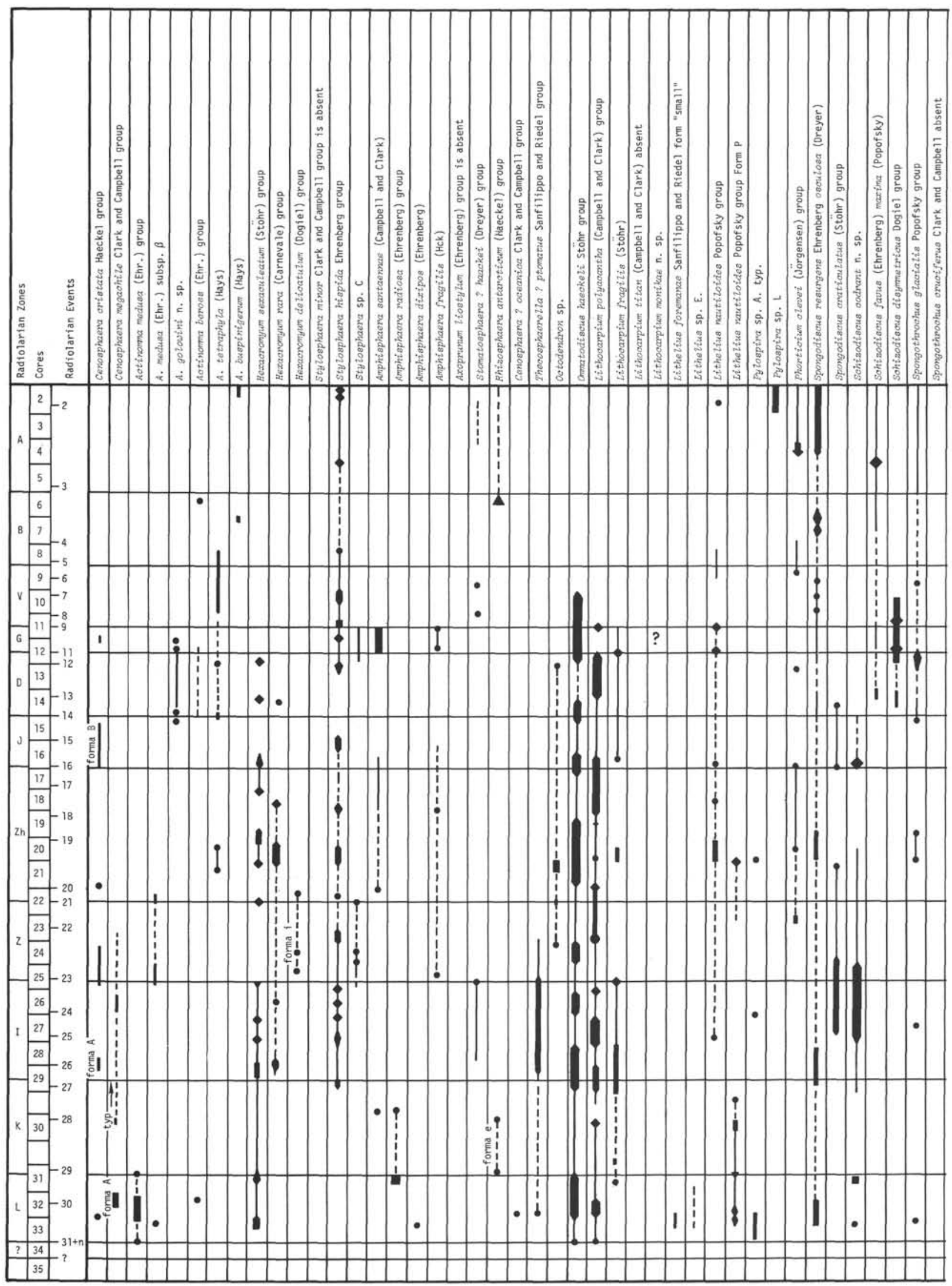




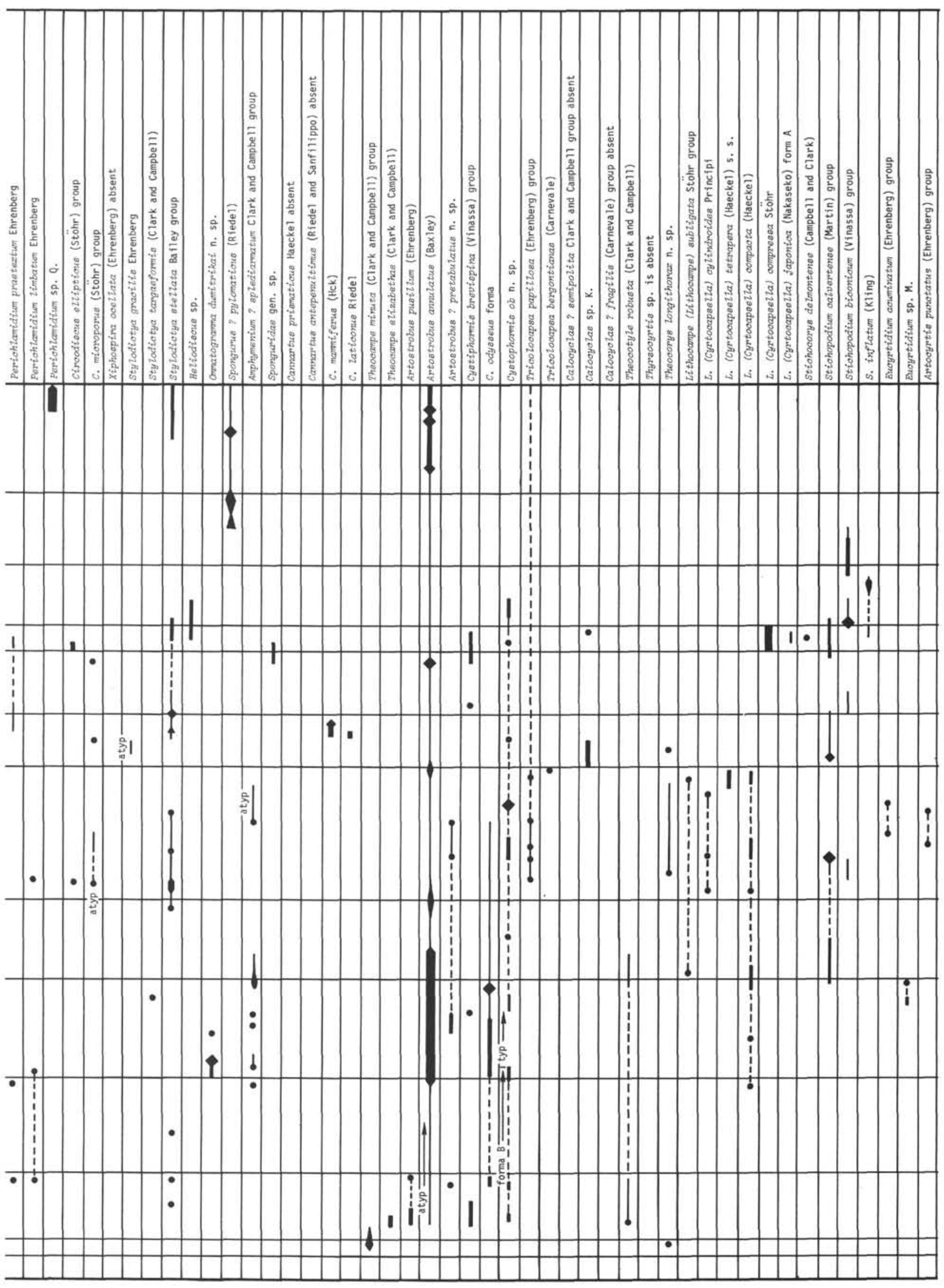




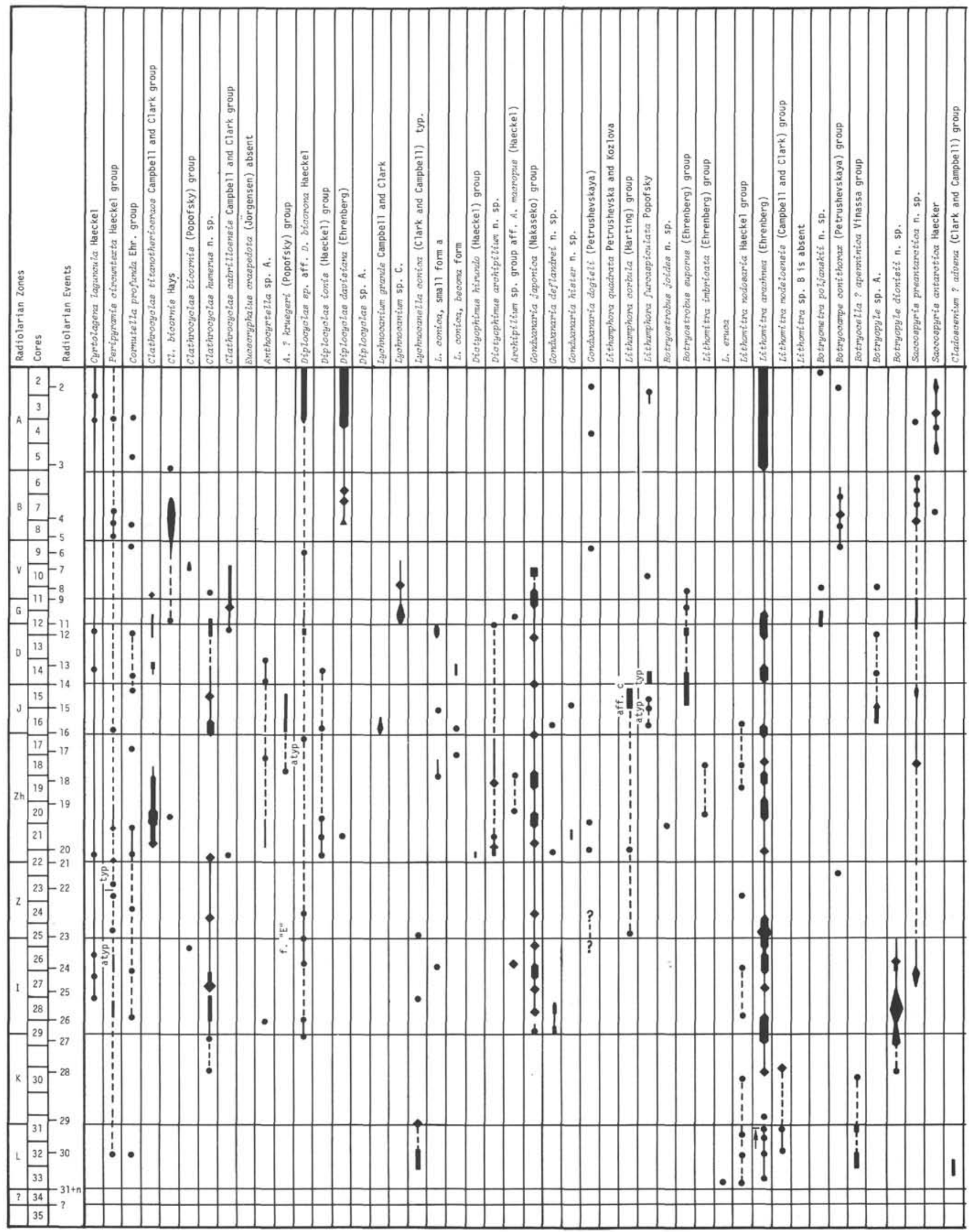


TABLE 4 - Continued

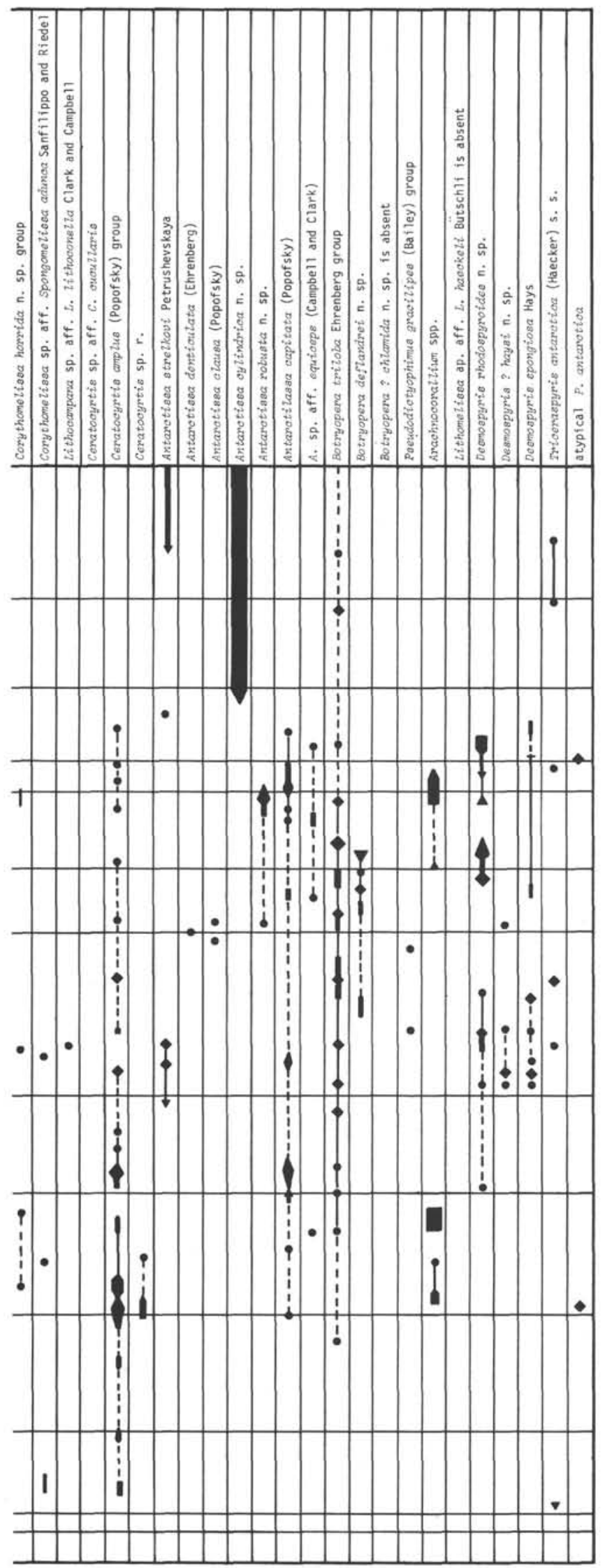

and Pacific Oceans occurred. This intermingling was not interrupted by the onset of the circumpolar circulation (evidence of which was found in the sediments cored at Site 280).

Radiolarians were encountered from 19 meters (Core 3 , Section 2) to 150 meters (Sample 16, CC) (Table 7). At 19-36 meters (Cores 3 and 4) skeletons were encountered of Actinomma tetrapyla, Stylosphaera hispida, Lithelius? nautiloides typ., Perichlamidium sp. Q, Stichopodium biconicum, Clathrocyclas bicornis Hays, Antarctissa capitata group, Androcyclas heteroporus, and even Lychnocanium grande. These enable the assumption that these cores contain sediments of Zone B and V, i.e., of the middle Pliocene, and are similar to the Antarctic deposits of that age. The sediments of Core 5 (36.0-45.5 m) contain very few radiolarians, which are frequently poorly preserved. The presence of Actinomma tetrapyla, Lithocampe subligata group, Stichopodium biconicum, and $\mathrm{Cl}$. bicornis Hays (which usually occur higher as well as lower) in Core 6, does not yield much with regard to age determination.

At 45.5-59.0 meters, the radiolarians are more abundant. However, it is impossible to establish those radiolarian zones which have been isolated for higher latitudes (i.e., for the Antarctic): more characteristic species, which would establish more rational division, are lacking. The presence of the species listed above for Core 5 , and the absence of species characteristic for the Pliocene or early Miocene deposits, indicate an upper Pliocene age. However, the occurrence of Ommatartus? cf. laticonus (Plate 7, Figures 9, 10) leads to the assumption that these sediments can be correlated with such upper Miocene zones of tropical deposits as the $O$. antepenultimus Zone. It is also possible that here, on the periphery of its area of distribution, $O$. laticonus is not too reliable an indicator-species for age determination.

At 59-74 meters (Cores 7 and 8), the picture is the same. There was no success in establishing the Antarctic, or the tropical zones, although Astromma hughesi was encountered here. The number of indicator species for age determination is rather small, and the reliability of those species which are available is uncertain.

At approximately 79 meters (Core 9, Section 3) sharp changes in the radiolarian fauna were observed: $C y r-$ tocapsella tetrapera and $C$. japonica, which are abundant below, become rather rare, whereas Circodiscus microporus disappears. There is also an appearance of Astromma hughesi and Actinomma golownini. The occurrence of Astromma petterssoni, Cyrtocapsella tetrapera, and Astromma hughesi at 74.0-83.5 meters enables a correlation of the sediments of this zone with tropical sediments of the $C$. petterssoni Zone. At 83.5-93.0 meters (Core 10), the spines of Orosphaeridae are extremely abundant, whereas other radiolarians are rare. Nevertheless the presence of Cyrtocapsella tetrapera permits confirmation of a middle Miocene age.

At 93.5-112.0 meters (Cores 11, 12) there are fewer spines of Oroscena than in Core 10, whereas specimens of other radiolarians are more or less common. Almost all of the species which could be useful for age determination disappear below 102 meters, except Cyrtocapsella tetrapera, which disappears at approximately 


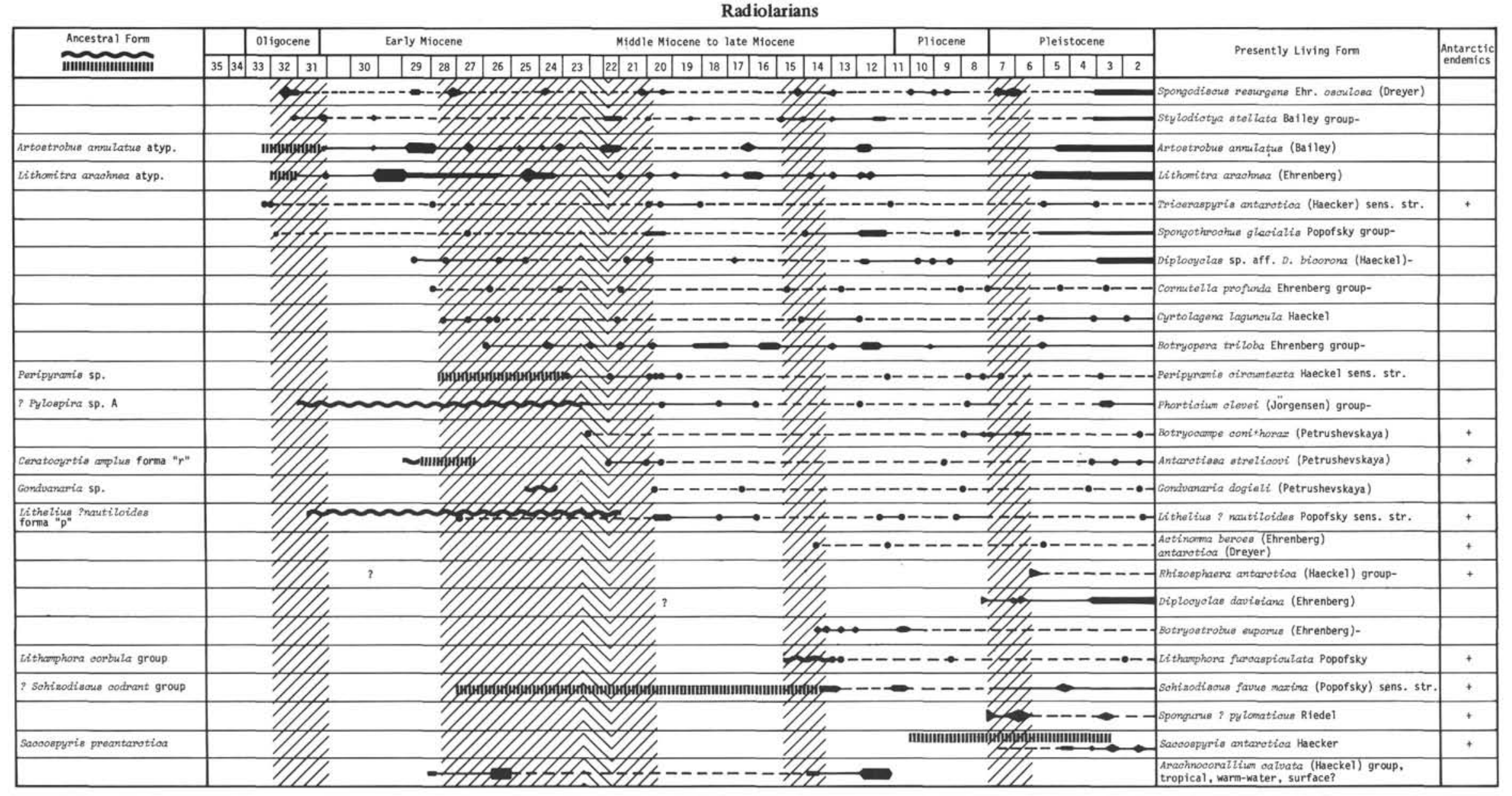


TABLE 6

Radiolarians, Zonation, and Events at Site 280 (Hole 280A)

\begin{tabular}{|c|c|c|c|c|c|c|c|c|c|c|}
\hline 11 & 10 & 9 & 7 & 6 & 5 & & 4 & 3 & 1 & Cores \\
\hline \multicolumn{3}{|c|}{$?$} & 4 & 3 & 2 & 1 & & $?$ & L & Radiolarian Zones \\
\hline & & & & & & & & & $\bullet$ & Cenosphaera cristata Haeckel group \\
\hline & & & & & & e & & & & Amphysphaera radiosa (Ehrenberg) \\
\hline & & & & & $\bullet$ & & & & & Hexacromyum sexaculeatum (Stöhr) group \\
\hline & & & & - & & -1 & & $-\rightarrow$ & & Axopmunum Ziosty zum (Ehrenberg) group \\
\hline & 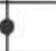 & & & $\bullet$ & & & 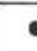 & & & Sty Zosphaera minor Clark and Campbell group \\
\hline & & & & 3 & & & & - & & Cenosphaera ? oceanica Clark and Campbell \\
\hline & & & & 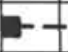 & $-t^{-1}$ & 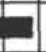 & & & & Centrocubidae gen. sp. \\
\hline & & & & - at & typ $\bullet$ & & & & & ammatodiscus haeckeli Stöhr group \\
\hline & & & & - & & $\square$ & & -+ & - & Lithocarpirm polyacantha (Campbell and Clark) group \\
\hline & & & & & & & & & & L. titan (Campbe11 and Clark) \\
\hline & & & & & & & & & & L. monikae n. sp. \\
\hline & & & & - & & & & & & Lithelius hexaxyphophoms Clark and Campbell \\
\hline & & & & & & & & & & Lithelius noutizoides Popofsky, Form P \\
\hline & & & & & & - & & & & L. foremanae Sanfilippo and Riedel \\
\hline & - & -- & & & & & & & & PyZospira sp. A typical \\
\hline & - & -- & & 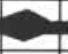 & & - & & & & Pylospira sp. A Form B \\
\hline & & & & $\bullet$ & & 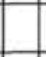 & & & & Spongodiscus resurgens Ehr. osculosa (Dreyer) \\
\hline & & & & & & 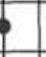 & & & & Sp. cratioutatus (Stöhr) group \\
\hline & & & & & & 9 & & & & Schizodiscus codrant n. sp. \\
\hline & 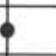 & & & & & & & & & Spongothrochus cruciferus Clark and Campbell \\
\hline & & & & $\bullet$ & & $\bullet$ & & & & Perichlamidium Limbatum Ehrenberg \\
\hline & & & & - & & 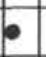 & & & & Porodiscus bergontianus \\
\hline & & & & & & 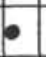 & & & & Circodiscus circularis Clark and Campbell \\
\hline & & & & $\bullet$ & & & & & & Xiphospira ocellata (Ehrenberg) \\
\hline & 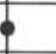 & & & - & & & & - & & Amphymerizom ? splediarmatum Clark and Campbell group \\
\hline & & & & & & - & & & 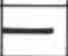 & Theocampe minuta (Clark and Campbell) group \\
\hline & & & & & & - & & & & Artostrobus pusilzum (Ehrenberg) \\
\hline & & & & 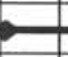 & & 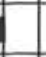 & & & & Calocyclas ? semipolita Clark and Campbell \\
\hline & & & -1 & -1 & -1 & & & & & Calocyclas ? fragilis (Carnevale) group \\
\hline & & & & - & - & -1 & & $--\rightarrow \rightarrow$ & & Eucyrtidium sp. M \\
\hline & & & & & & - & - & & & Dictyophimus himundo (Haeckel) atyp \\
\hline & & & & $\bullet-$ & -1 & -1 & & $---\infty$ & & Botryostrobus joides n. sp. \\
\hline & & & & & & & & $\bullet$ & & Lithamitra imbricata (Ehrenberg) group \\
\hline & & & & - & $\rightarrow$ & - & & & & Lithomitra eruca \\
\hline & & & & & & & & $\bullet$ & & L. nodosaria Haeckel group \\
\hline & & & & & & & 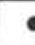 & & & Lithomitra modeloensis (Campbell and Clark) \\
\hline & & & & & 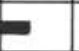 & & & & & Lithomitra sp. B \\
\hline & & & & $\bullet$ & -- & - & & $-\rightarrow \rightarrow$ & & Diplocyclas sp. A \\
\hline & & & & $\bullet-$ & -- & -1 & & $---c$ & & Lithocampana Zithoconezla Campbell and Clark \\
\hline & & & & & & $\bullet$ & & & & Corythomeliss $\alpha$ sp. aff. S. advera (Sanfilippo and Riedel) \\
\hline & & & - & -1 & $-\rightarrow$ & - & $\rightarrow$ & & & Ceratocyrtis sp. aff. C. cuculzaris \\
\hline & & & & - & $\longrightarrow$ & & & & & Lithomelissa sp. aff. L. haeckeli Bütschli \\
\hline & & & & $\bullet$ & & & & & & Betryometra? spongiosa n. sp. \\
\hline
\end{tabular}


TABLE 7

Radiolarians, Zonation, and Events at Site 281

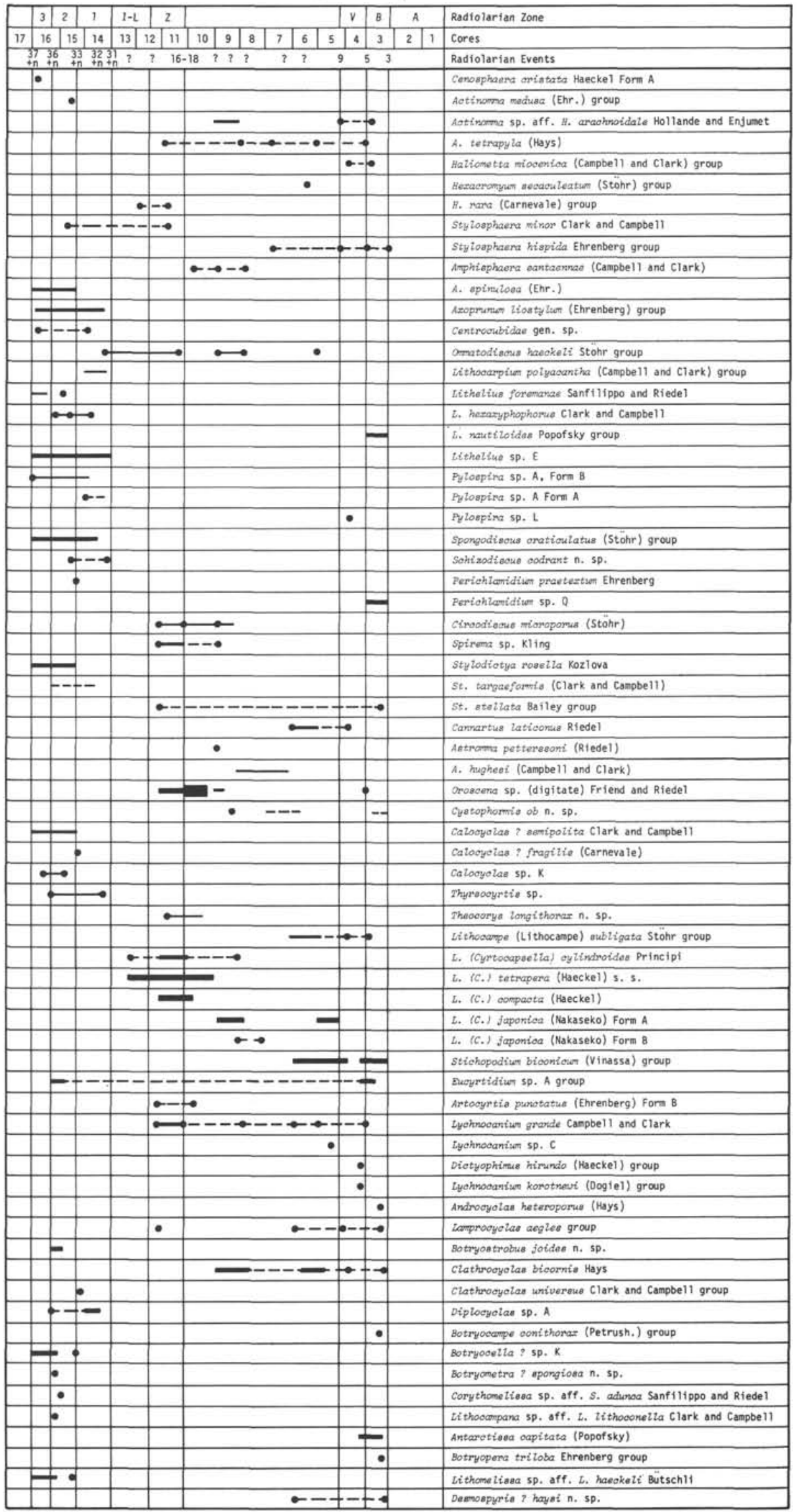


112 meters. This event enables a tentative correlation of these sediments with the upper part of the tropical $L y c h$ nocanium bipes Zone. The sediments of Core 13 (112-121 m) do not contain radiolarians.

At approximately 125 meters (Core 14 , Section 3 ) to 133 meters (Core 15, Section 2), Actinomma medusa, Axoprunum liostylum, Lithelius sp. E, Thyrocyrtis sp., and Diplocyclas sp. A are present. This assemblage is similar to an unnamed assemblage at Site 276 (Cores 34, 33) (Table 2).

At 133-150 meters (Cores 15, 16), species encountered, in addition to those listed for the upper part of Core 15 include: Amphisphaera spinulosa, Calocyclas? semipolita, Botryocella? sp. K, and Lithomelissa sp. aff. L. haeckeli. Although the set of radiolarians is not identical, it is extremely similar to that at Hole $280 \mathrm{~A}$, which is related to the upper Eocene Zones 2 and 3 (Tables 2 and 6).

Sample 16, CC contains a complex of species which on the whole resembles that of the Theocampe mongolfieri Zone, described by Sanfilippo and Riedel (1973) for the tropical sediments. Below 150 meters radiolarian skeletons were not encountered.

The occurrence at Site 281 of Ehrenberg species, Clark and Campbell species, as well as other species characteristic for the Eocene of the Caribbean Basin and California, confirms the connection in the Eocene of the area at Site 281 and the Pacific Ocean (possibly because of surface currents and median undercurrents). However, the results do not indicate how far Sites 281 and 280 were from each other during the Eocene. The set of Eocene species is very similar at both sites, and they have the same common species. It is interesting to note that among them are such widely distributed species as the Axoprunum liostylum group and Calocyclas? semipolita. These were also encountered in the boreal Eocene radiolarian fauna in the USSR.

On the other hand, specific species were encountered at Hole 280A which were lacking at Site 281. Possibly, these differences are due to the fact that the sediments at Site 281 are not deep-water sediments as those at Site 280. It is also feasible that the Eocene species specific for Site 280 are the first Antarctic endemic species which developed as a result of the onset of the hydrological isolation of the Antarctic areas. However, whether these species were widely distributed if not in the tropics, then at least in the peripheral or transitional areas should be checked in detail.

\section{MORPHOLOGY OF THE SKELETON IN POLYCYSTINE RADIOLARIANS}

Since all conclusions on the temporal and geographic distribution of polycystine radiolarians and on their evolution are based on morphological investigations, the problems of comparative morphology require special attention.

The skeleton of Polycystina consists of radial and tangential elements. The radial elements are inner bars and outer spines which radiate from the center. The function of the inner bars is to provide unity to the skeleton, and at the same time to subdivide the polyenergid polycystine cell into lobes, parts, and areas, es- sential for the intensification of metabolism. The function of the outer spines is to support the axopodia, the basic organellae of Polycystina, which ensure the possibility for them to lead a planktonic way of life.

It has been assumed that Polycystina, in contrast to Phaeodaria, have solid radial spines. To the author's knowledge, only Deflandre (1972) described in his remarks on Nototripodiscinus (or Archipilium?) hollow polycystine spines. Deflandre's studies, carried out by means of a light microscope, were confirmed by using a scanning electron microscope (Plate 43, Figures 3-5). Moreover, the SEM showed that hollow spines are common in larcoidean radiolarians (Plate 33, Figures 1, 2; Plate 32, Figures 4, 5). Probably Thecosphaerella ptomatus has hollow spines also.

In nassellarian radiolarians, especially in Cannobotryoidae, there are usually tubules, but they are considered as secondary formations which develop along the simple primary spine. However, besides the spines of Nototripodiscinus, there are also primary tubular spines in other Nassellaria. Thus, for instance, in some forms (Plate 42, Figure 5) the apical horn is penetrated by a canal, although the latter does not open at the apex but laterally (Figure 6, E).

Whether the inside of the tubular polycystine spines were penetrated by axopodia, or whether the inner canal does not have such a function, is difficult to decide. It is only clear that the existence of hollow spines is due to the peculiarities of the formation of skeletal spines during ontogenesis. It should also be noted that apparently

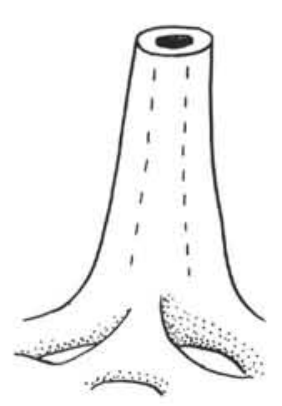

A

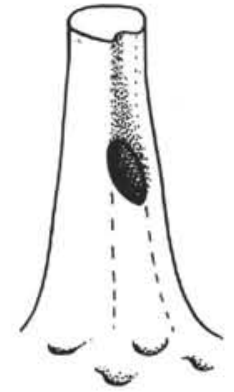

B

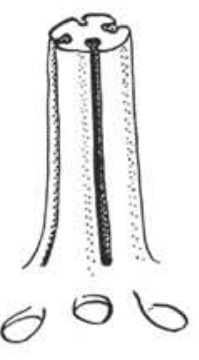

$\mathrm{E}$

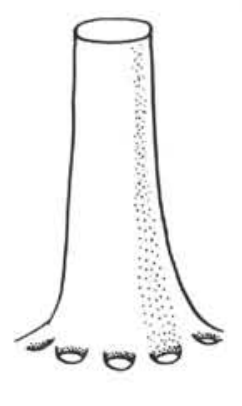

C

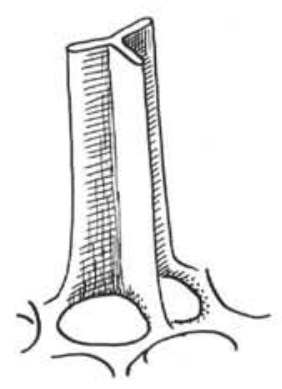

$\mathrm{F}$
Figure 6. The various kinds of the radial spines in Polycystina (?). 
this type of spine in Polycystina is archaic and uncharacteristic for the Cenozoic fauna as a whole.

The tangential formations of the skeleton represent shells which are latticed or porous, etc. The pores at the base of the spines represent an exit for those axopodia which accompany the radial spines. The pores can be close to or farther from the base of the spine. In cases where the pores are further away, their number cannot be precisely determined, but it is rather large. The spine itself is cylindrical (Figure 6, A-C). If the pores are close to the base of the spine, their number usually does not exceed 4-5 (Plates 28 and 29; Plate 44, Figure 3). The base of the spine has more or less deep furrows or even canals, which are apparently for the passage of axopodia (Figure 6, D-F). An ultimate case of specialization is the spine consisting of three plates, fused together with one rib, which in section resembles the letter Y (Figure 6, F). There are three pores at the base of this spine. An analogous picture of the stabilization of the ribs of radial spines, as well as the number of pores at the base of the spines and the number of axopodia accompanying the spines, is given by Schewiakoff (1926) for Acantharia. In Acantharia, of course, the minimal (and optimal?) number of facets and pores is not three but four.

\section{Wall Structure and Pore Distribution}

Referring to the tangential shells it is first necessary to consider the structure of their walls and the distribution of pores. The pores can be more or less large, equal or unequal, regular or irregular. It appears to the author that, during the evolution of Polycystina, the pores became regular and there were two basic directions for the substantiation of such an arrangement: (1) the distribution of pores was linear, i.e., along the angles of the tetragons or rectangles (Figure $7, \mathrm{IIa}, \mathrm{b}$ ); (2) the pores were distributed in a checkerboard order, resembling

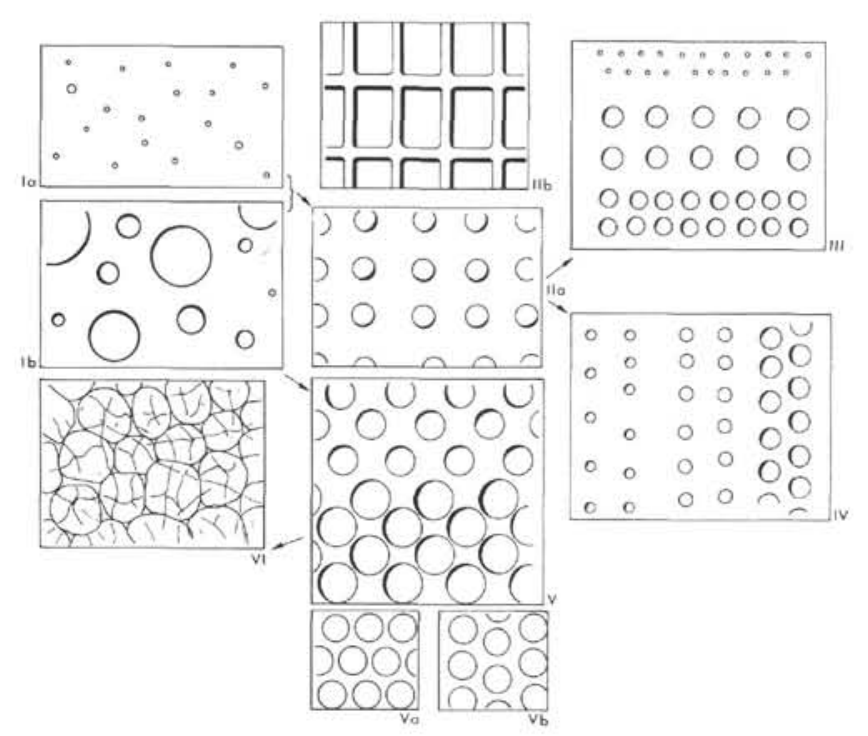

Figure 7. Disposition of the pores in Polycystina. more or less "a hexagonal packing" (Figure 7, V). In most cases, predominantly longitudinal or transverse rows were frequently distinguished (Figure 7, III, IV, $\mathrm{Va}, \mathrm{b})$ and especially so in Nassellaria. Most advanced in Nassellaria, as well as in Spumellaria, is obviously the checkerboard order or the hexagonal order in the distribution of pores. The pseudoaulophacid structure represents nothing more than a single case of the hexagonal distribution of bars (in this case, the shells are very close). The development of such a checkerboard or hexagonal order of distribution, prompted the most perfect (as I believe) type of structure of the tangential formations in Polycystina-an irregular intertwining of the thinnest filaments, which we customarily call spongy (Figure 7, VI). Such a network penetrates more or less the entire polyenergid radiolarian cell, requiring less material for its structure; it also causes less increase in the body weight than a porous shell.

The changes in the distribution of pores occurred parallel with a change in the wall thickness. In most evolutionary lines, the walls become gradually thinner, which allowed the establishment of approximately the same stages (Figure 8). Frequently, the walls become thinner immediately along the margin of the pores, in which case the pores are frequently funnel-shaped or bordered. Occasionally, the center of the interporous septa is thin and flattened, as are the crests between the pores. The walls also become smooth. The thinning may reach such an extent that even the integrity of the walls is threatened. The appearance of longitudinal ribs (Pterocorys hertwigii, Litharachnium or Sethophormis aurelia) might be due to just such cases. In Nassellaria, the onset of irregularly distributed bars and the formation of loose "spongy" intertwinings is obviously also due to the thinning of the wall.

With regard to nassellarian radiolarians, it is important to consider the general body form and the interrelation of its parts, as well as with the structure of the first segment, i.e., the cephalis.

\section{Form of the Nassellarian Body}

The form of the nassellarian body frequently has a clearly expressed heteropolarity, because the first section (cephalis) is closed, and a specific, complicated structure, whereas the structure of the last (apertural) section is simple and frequently more or less wide open. However, disregarding the details of the inner structure, approximately a third of the nassellarian skeletons can be described as spherical, ellipsoidal (Figure 9, I), fusiform, or, as bodies of rotation, composed of two, three, or four hemispheres located along one axis (Figure 9, II, VI, VII). Such bodies sometimes have small hair-like appendages, i.e., poorly developed radial spines. A comparatively small number of nassellarians (representatives of Cannobotryoidea and some Spyrida) have skeletons of a completely irregular general form: they are composed of three chambers (which are frequently unequal to each other and more or less asymmetrically located. These usually represent bodies of irregular form (Figure 9, III). Many of these skeletons are 

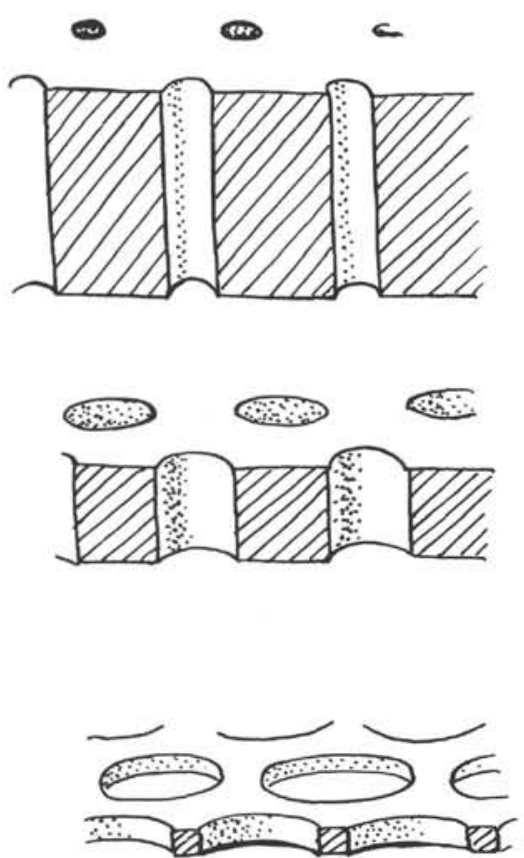
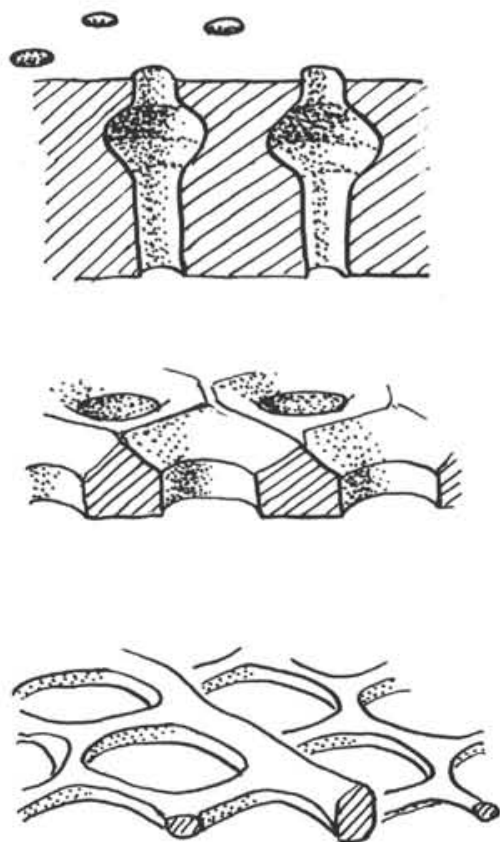
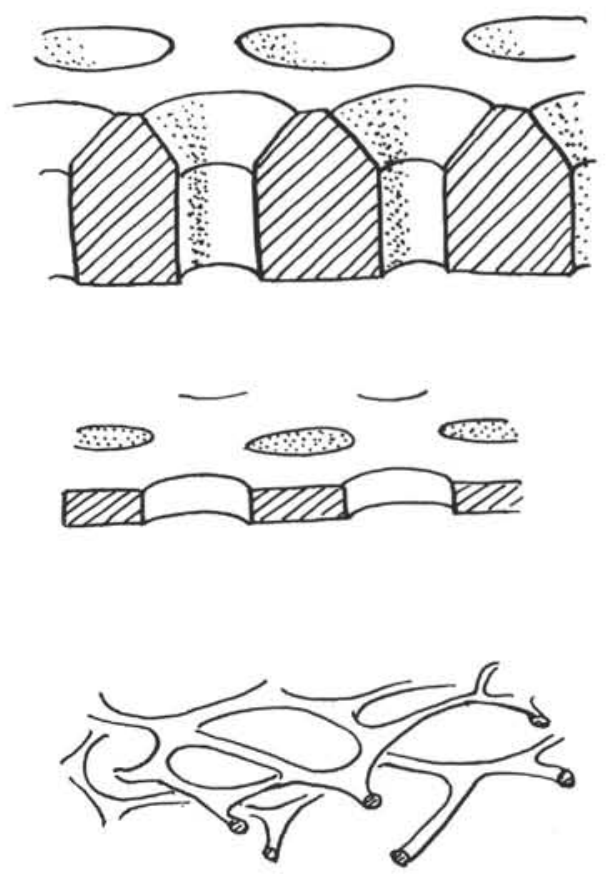

Figure 8. Various kinds of shell walls in Nassellaria.

TABLE 8

Taxonomic Division of Spumellaria

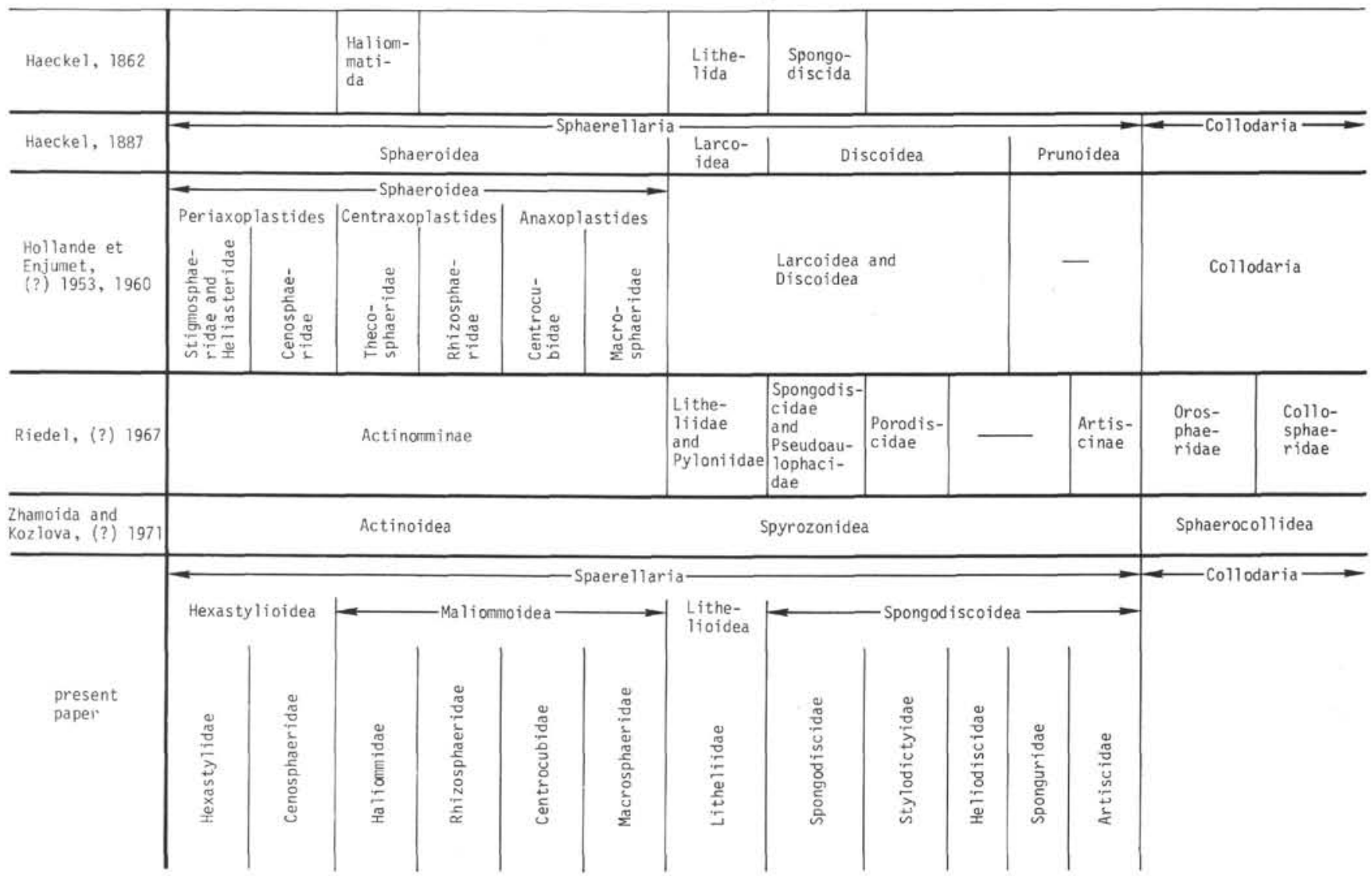




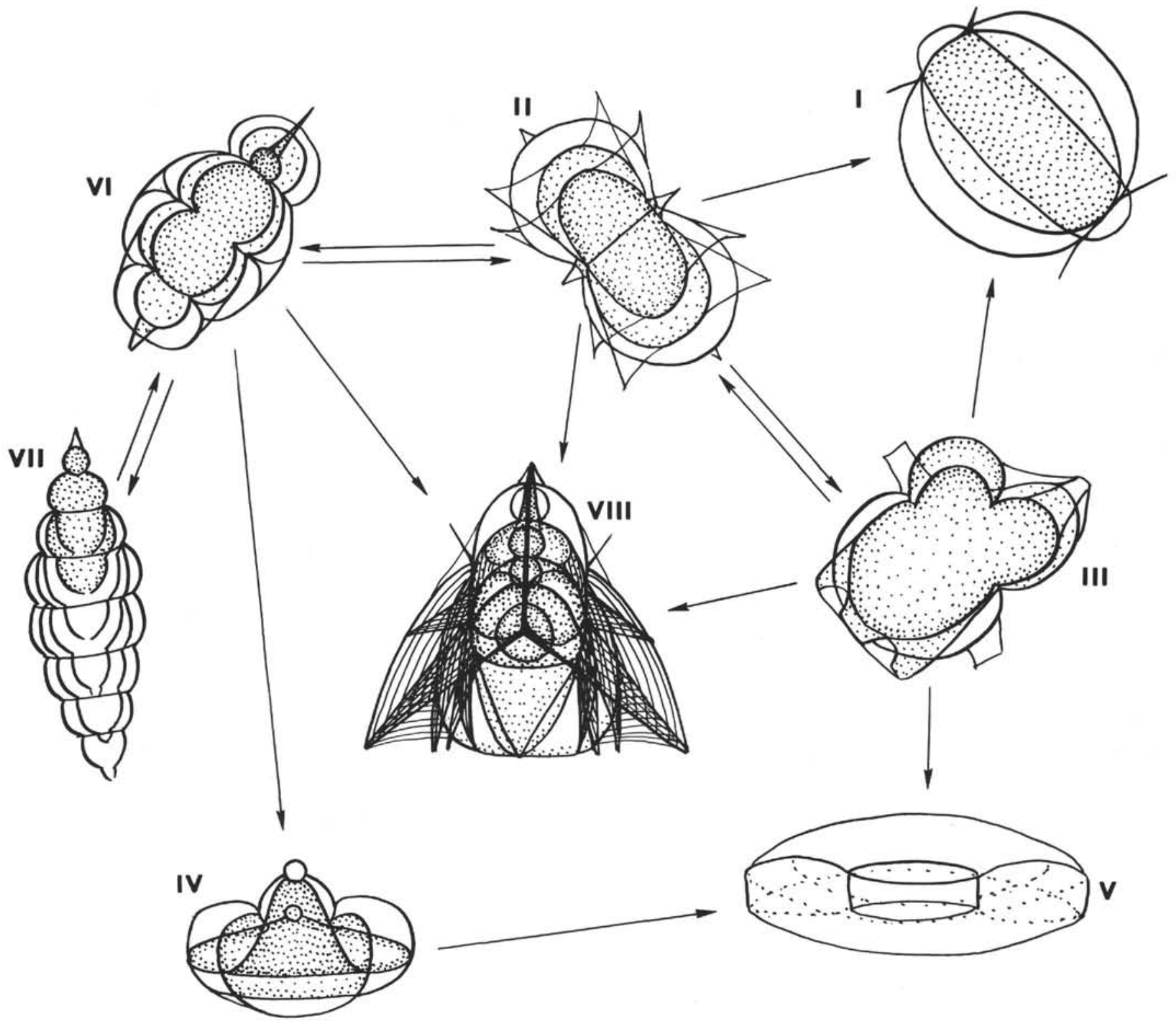

Figure 9. Skeleton shape in the Nassellarians.

flattened laterally or in an "anterior-posterior" direction, and remotely resemble discs. The study of the history of the origin and development of Cannobotryoidae and the Spyrida shows that this form of the body is the derivative of the two, more or less equal, hemispheres shown on Figure 9, II.

Very common is the form compressed in the direction of the basic axis (Figure 9, IV). These are either complicated discoidal constructions with annular constrictions and hemispherical or conical protuberances, characteristic for many Cretaceous genera described by Dumitrica (1970) or they merely represent the fragile cones of Neosciadiocapsidae and some other species. The flattened, almost completely regular discs and even rings (Figure 9, V) are not usually connected in their origin with the flattened skeletons, but originate independently, mainly among Spyrida (Figure 9, III).

Finally, the most notable construction characteristic for nassellarians, the tripod (Figure 9, VIII), developed independently at various evolutionary stages. Because of the small number of radial spines in Nassellaria, their distribution from the center toward the four poles of a pyramid seems to be the most advantageous one. This is also the best variant of the skeleton which expands and supports the given volume of the cytoplasmatic body, and represents simultaneously a convenient body of rotation for that movement which they render to the axopodial protozoan. Such a skeletal form is approximately as frequent in nassellarians as the flattened discoidal one. 
Although undoubtedly the development of a more complete form of the body in Polycystina was of great importance for their adaptation to a planktonic way of life, it is erroneous to consider the shell itself as playing the role of a parachute system: the shell is too small (Petrushevskaya, 1970). In order to determine which form of the body is most suitable, it is necessary to have more data on the distribution of pseudopods and on the movement of Polycystina.

As important as the development of the outer form was the achievement of a more rational inner subdivision of the body by means of bars and septa in Nassellaria. All the segments, except the cephalis and thorax, are divided by a more or less sharp and deep annular constriction or ridge in nassellarians. Sometimes the ridges of the various segments are united into a spiral.

Sometimes the structure of the cephalis is rather complicated and its connection with the thorax is also not simple. Several basic types of cephalic structure can be isolated in Nassellaria (Figure 10); most of them have been described repeatedly in the literature (Bütschli, 1882; Riedel, 1953, 1958; Petrushevskaya, 1962-1971c; Foreman, 1966, 1968, 1973; Dumitrica, 1970), but as a rule the measurements of the described cephalis were not taken into consideration by any author. On the other hand, almost all of the cephalis types can be accommodated into two sizes: $18 \mu-30 \mu$ or $50 \mu-70 \mu$.

Because of the generally small size of Nassellaria, this difference itself is very important. Moreover, in the case of a small cephalis, two to three (or more) segments are, as a rule, well developed and the basic part of the protozoan body is composed only of them. If the cephalis is large, only the thorax (of the other segments) is developed (but not always). In such a case, the role of the cephalis and, consequently, also of its details, is much greater. A high taxonomic rank (generic and family features) might be assigned to the details of the structure of large cephalises only. In the case of multisegmented shells with small cephalises, more attention should be paid to the structure of the other segments.

It is feasible that in many lines of the development of Nassellaria, an elongation of the cephalis and its eucephalic part occurred parallel and independently. This elongation was accompanied by a constriction of the lower part of the eucephalic lobe and the formation of the so-called neck (Figure 10, I, II, III, VI, VII).

If this elongation and expansion of the eucephalic part was accompanied by an increased growth of the cephalic parts surrounding it, this resulted in the appearance of complicated cephalises, similar to the type of Cannobotryoidae. If, however, the increased growth and elongation of the additional parts of the cephalis lagged behind the increase of the upper part of the eucephalic lobe, this resulted in the appearance of the so-called cephalis with a neck, which is characteristic for many Pterocoryidae and Lophophaenidae (Petrushevskaya, 1973a).

The formation of a cephalis with a sagittal ring approximately $60 \mu$ in diameter is quite a special case, leading to the formation of the specific suborder Spyrida.

\section{SYSTEMATIC PALEONTOLOGY \\ Order SPUMELLARIA \\ Superfamily HEXASTYLIOIDEA}

Hexastylida Haeckel, 1881, p. 450; 1887, p. 171.

Periaxoplastides Hollande and Enjumet, 1960, p. 85.

Diagnosis: The axoplast is larger than in Halimmoidea and situated near the nucleus. There is a group of axonems and the central capsule is monaxon heteropolar. The first medullar shell (if present) is about $40 \mu-50 \mu$ in diameter, is arranged around the axoplast or may be (partly) in the nucelus. This shell is composed of 4-10 radial spines rising from the same center or from the ends of some bars, and arches connecting these spines. The second shell is cortical, $100 \mu$ or greater in diameter. It may be latticed or alone it may represent "spongy" meshwork. The name Hexastylioidea was picked because Hexastylus is known to be of periaxoplastid construction (Hollande and Enjumet, 1960).

Paleozoic-Recent. In the Mesozoic and Cenozoic it is rather rare. Some species of Entactiniidae Riedel seems to belong in this superfamily (Foreman, ?1963). It is difficult to determine if the type species of Entactinia belongs in this group.

Family HEXASTYLIDAE Haeckel, emend.

Hexastylida Haeckel, 1881, p. 450; 1887, p. 171.

Centrolonchidae, Campbell, 1954, p. 60.

Stigmosphaeridae Hollande and Enjumet, 1960, p. 89.

Heliasteridae Hollande and Enjumet, 1960, p. 91.

Diagnosis: The first shell (if present) is included in the central capsule; strong outer radial spines.

\section{Genus LONCHOSPHAERA Popofsky}

Lonchosphaera Popofsky, 1908, p. 217, non Campbell, 1954, p. 68. Type species Lonchosphaera spicata Popofsky, 1908, taf. 24, fig. 2.

Diagnosis: Very often the main radial spines are branched under the cortical shell, increasing the number of external spines. The total number of outer radial spines is nondetermined $(5-40)$. The cortical shell is of slightly variable shape. Pores are irregular, 10-20 on a half of the equator. Small by-spines (nonconnected with the branches of the main radial spines) may be present. Internal microsphere (the first shell) as irregular polyhedra with a variable construction.

Miocene(?)-Recent. It is difficult to indicate the difference of the genus from Hexastylus and Centrolonche.

\section{Lonchosphaera spicata Popofsky}

(Plate 17, Figures 4-8)

Lonchosphaera spicata Popofsky, 1908, p. 218, pl. 24, fig. 2, pl. 25, fig. $2,7$.

Internal polyhedra is rather simple, appearing like a silicoflagellate skeleton, diameter about $18 \mu-20 \mu$. There are $12-15$ pores on the $70 \mu$ $80 \mu$ cortical shell; 6-10 external radial spines.

Pliocene-Recent. Antarctic.

\section{Family CENOSPHAERIDAE Deflandre}

Cenosphaeridae Deflandre, 1953, p. 420; Hollande and Enjumet, 1960, p. 87.

Diagnosis: Hexastylioidea with the first shell (if present) included in the central capsule. External radial spines (if present) are weak. Cortical shell with $10-20$ pores on half of the equator.

Tertiary-Recent.

\section{Genus CENOSPHAERA Ehrenberg}

Cenosphaera Ehrenberg, 1854, p. 237; Haeckel, 1887, p. 61; Campbell, 1954, p. 48.

Circosphaera Haeckel, 1887, p. 63; Campbell, 1954, p. 48, 63.

Caenosphaera Bertolini, 1935; Campbell, 1954, p. 48. Type species Cenosphaera plutonis Ehrenberg, 1854, taf. 35B, fig. 20.

Cortical shell with $10-20$ pores on a half of the equator. Pores rather irregular.

Cenosphaera cristata Haeckel group

(Plate 1, Figures 3, 4, Plate 17, Figure 2)

(?)Cenosphaera plutonis Ehrenberg, 1854, taf. 35B, fig. 20.

Cenosphaera cristata Haeckel, 1887, p. 66; Riedel, 1958, p. 223, pl. 1, fig. $1,2$. 
Cenosphaera sp. Petrushevskaya, 1967, p. 15, pl. 7, fig. 1, 2. Cenosphaera varieporata Vinassa de Regney, 1900, tav. 1, fig. 1. Cenosphaera porosissima Vinassa de Regney sensu Martin, 1904, p. 459 , pl. 130 , fig. 24 only.

Cenosphaera hispida Carnevale, 1908, p. 7, tav. 1, fig. 3.

Miocene-Recent. Miocene individuals (Form B) have larger cortical shell (up to $150 \mu$ ) and internal microspheres (polyhedra) very similar to Lonchosphaera. No external radial spines but some specimens have small by-spines. They occur in late Eocene-Oligocene. This form was possibly illustrated by Sanfilippo and Riedel, 1973, pl. 22, fig. 2, as Collosphaerid gen. sp.

\section{Cenosphaera megachile Clark and Campbell}

(Plate 1, Figures 6-8)

Cenosphaera megachile Clark and Campbell, 1945, p. 5, pl. 1, fig. I. Cenosphaera sp. Sanfilippo and Riedel, 1973, p. 490, pl. 4, fig. 4.

Cortical shell is thick-walled, similar to Haliommidae. Small external radial spines can be seen in some Oligocene individuals (form A). Pores arranged as those in the typical Cenosphaera plutonis Ehrenberg.

Oligocene-Miocene.

\section{Superfamily Haliommoidea}

Haliommatida Haeckel, 1862, p. 423; 1887, p. 230.

Actinommida Haeckel, 1862, p. 440; 1887, p. 251; Riedel, 1967a, p. 294 , part.

Sphaeroidea Haeckel, 1887, p. 103; Hertwig, 1879, p. 39; Haeckel, 1887 , p. 50; Tregouboff, 1953 , p. 342 ; Deflandre, 1953, p. 415; Strelkov, Khabakov, and Lipman, 1959, p. 430.

Centraxoplastides Hollande and Enjumet, 1960.

Actinoidea Kozlova and Zhamoida, ?1969.

Diagnosis: The axoplast (the center of the axoplodial filaments of the axonems) is rather small if present and situated in the center of the nucleus. Central capsule is radial. The first medullar shell is about $15 \mu$ $28 \mu$ in diameter (generally about $20 \mu$ ) if present, and is arranged around the axoplast in the nucleus. Second medullar shell is often about $40 \mu$ in the diameter if present. The first and the second shells may be latticed and well designed, but sometimes spongy and confused. The main radial spines (rising from the first shell) are not numerous (4-10, generally about 7$)$.

Paleozoic-Recent.

Remarks: The name Actinommidae (sensu Riedel, Petrushevskaya and Kozlova, 1972, and others is not used because of the priority, but mainly because of the difference in the group determinations. The group under consideration includes all the Centroaxoplastides and perhaps some of the Anaxoplastides (or Crypotoaxoplastides) of Hollande and Cachom-Enjumet: it seems possible that the central axoplast may sometimes be reduced.

\section{Family HALIOMMIDAE Haeckel, emend.}

Haliommatida Haeckel, 1862, p. 423; 1887, p. 230.

Actinommida Haeckel, 1862 , p. 440.

Stylosphaerida Haeckel, 1881; Deflandre, 1953, p. 417.

Diagnosis: Haliommoidea with three or four shells. The first three shells are latticed, the fourth (if present) may be of an irregular meshwork. Diameter of the outer shell is generally not more than $200 \mu$. Not more than 20 radial spines outside the spherical, ellipsoidal, or even pear-shaped shells.

\section{Genus HALIOMMA Ehrenberg, emend.}

Haliomma Ehrenberg, 1838, p. 128; Haeckel, 1887, p. 230; Popofsky, 1913, p. 101; Campbell, 1954, p. 62.

Haliommura Haeckel, 1887 , p. 237 ; Campbell, 1954, p. 62. Type species Haliomma aequorea Ehrenberg, 1854, taf. 22, fig. 35.

Thecosphaera Haeckel, 1881, p. 452; 1887, p. 78; Campbell, 1954, p. 50; Hollande and Enjumet, 1960, p. 111; Nakaseko, 1971a p. 59, part.; Petrushevskaya and Kozlova, 1972, p. 519=Thecosphaerantha Haeckel, 1887, p. 78; Campbell 1954, p. 50. Type species Thecosphaera tripodictyon Haeckel, 1887, not illustrated.

Thecosphaerella Haeckel, 1887, p. 80; Campbell, 1954, p. 50. Type species Haliomma inerme Haeckel, 1860 (Haeckel, 1862, taf. 24, fig. 5).

Diagnosis: Haliommidae with three shells, generally without external main radial spines. Shell ratio is about $1: 2: 5$. The pores on the third shell are nearly of equal size, with $10-15$ pores on the half of the equator of the third shell. The genus has abundant Eocene-Miocenespecies (Plate 1, Figure 5).

\section{Genus ACTINOMMA Haeckel}

Actinomma Haeckel, 1862 , p. $4401 ; 1881$, p. $453 ; 1887$, p. 251 ; Campbell, 1954, p. 64; Hollande and Enjumet, 1960, p. 110; not Nigrini, 1967, p. 26. = Actinometta Haeckel 1881, p. 453; Campbell, 1954 , p. 65 . Type species Haliomma trinacrium Haeckel, 1860 (Haeckel, 1862, pl. 24, fig. 6-8).

Cromyechimus Haeckel, 1881, p. 454; 1887, p. 263; Campbell, 1954, p. 66. $=$ Chromyechinus Jörgensen, 1905, p. 117. Type species Cromyechinus icosananthus Haeckel, 1887, pl. 30, fig. 1.

Hexalonchilla Haeckel, 1887, p. 184; Campbell, 1954, p. 62. Type species Hexalonche pythagorea Haeckel, 1887, pl. 22, fig. 1.

Heliosommura Haeckel, 1887, p. 241; Campbell, 1954, p. 62. Type species Heliosomma hastatum Haeckel, 1887, pl. 28, fig. 4.

Echinommura Haeckel, 1887, p. 258; Campbell, 1954, p. 66. Type species Echinomma toxoneustes Haeckel, 1887, pl. 29, fig. 1.

Sphaeropyle Dreyer, 1889, p. 89; Campbell, 1954, p. 66. Type species Sphaeropyle langii, Dreyer, 1889, fig. 54 .

Diagnosis: Haliommidae with three or four shells and 6-20 outer radial spines. Shell ratio is about $1: 2.75: 8.5: 11$. The pores on the third shell are irregular, often of a different size. Rarely more than 7-11 pores on the half of the equator of the third shell. Elongated fourth shell (if present).

Remarks: No strong evidence at present that the species, known as Cromyechinus langii, C. antarctica (Dreyer), Actinomma boreale Cleve, Haliomma beroes Ehrenberg, and other similar forms (Plate 2, Figure 15) were derived from the same ancestors as the species known as Hexaconthium arachnoidale Hollande and Enjumet gr. (Petrushevskaya and Kozlova, 1972, pl. 9). At first glance they look quite different, but the type species of Actinomma (the Recent $A$. trinacrium) looks very similar to the forms of $A$. beroes, $A$. borealis, or the $A$. antarctica group (specimens with only three shells). It is nearly impossible to distinguish them. On the other hand, some Tertiary species Actinomma shwageri Stohr; A. arachnoidale Hollande and Enjumet (see Petrushevskaya and Kozlova, 1972, pl. 9, fig. 7); and Actinomma golownini $\mathrm{n}$. sp. (Plate 2, Figure 16) are also rather similar to A. trinacrium. The Tertiary Actinomma aff. trinacrium looks like $A$. medusa group (compare Figures 6-8 and Figure 16, Plate 2): they might have descended from the same ancestor. This is why all species are placed here in Actinomma. It is very probable that after a more detailed investigation, Actinomma shwageri, A. arachnoidale, and A. medusa will be placed in a separate (new?) genus.

\section{Actinomma medusa (Ehrenberg) emend. group}

$$
\text { (Plate 2, Figures 6-8) }
$$

Haliomma medusa Ehrenberg, ?1844a, p. 83; 1854, taf. 22, fig. 33 (only).

Xyphosphaera apenninica Vinassa var. longistylus Principi, 1909, p. 6, pl. 1, fig. 12 .

Actinomma okurai Nakaseko and Nishimura, 1971, pl. 1, fig. 3-5 (only).

Shell ratio is $1: 3: 10$, however, the two inner shells are often destroyed. The third shell is of an irregular shape, thick-walled. Pores of different size and irregular outline, with about 12 pores on the half of the equator. Outside spines are nearly cylindrical, variable length and strength. Not all the spines connecting the second and third shells project outwards. About 8-11 spines; often only four or two are pronounced.

Oligocene-Miocene, Very variable species. Some forms of the species likely gave rise to neat spherical forms. Others, with an irregular surface and a reduced number of the outer spines, look very similar to some Axoprunum species.

\section{Actinomma medusa (Ehrenberg) subsp. $\beta$ (Plate 2, Figure 10)}

Haliomma medusa Ehrenberg, ?1844a, p. $83 ; 1854$, taf. 22, fig. $34 \mathrm{a}$, b (only).

Differs from more typical $A$. medusa by the smaller size of the third shell, and the greater number of pores (15-17 instead of 10-14) on half of the equator.

Oligocene-Miocene. 


\section{Actinomma golownini n. sp.}

(Plate 2, Figure 16)

The second shell is about $45 \mu$ in diameter, the third about $110 \mu$ $120 \mu$. The fourth shell was absent in all specimens found. Six radial spines rising from the second shell go out from the third shell. The other four spines rise from the third shell and have no connection with the second shell. All 10 spines have acute blades, are wide near the third shell but become very thin at about $60 \mu$ so they look like spikes. Pores on the third shell are rather regular, nearly of the same size, and polygonal. The bars between the pores are very narrow. Short byspines rise from the third shell and are not always seen.

The description is based on 23 specimens from Site 278 (Cores 1215 ) and on some specimens from the core of $\mathrm{Ob}$ Station 256. Holotype no. 62242 in the Marine Department. The species is named after Vasilij Michailovich Golownin (1776-1831), Russian investigator of the southern hemisphere on the ships Kamtchatka and Diana.

\section{Actinomma sp. group aff. Hexaconthium arachnoidale Hollande and Enjumet}

(?)Actinomma schwareri Stöhr, 1880, p. 92, pl. 2, fig. 9.

Hexaconthium arachnoidale Hollande and Enjumet, 1960, p. 110, pl, 53 , fig. 1.

Actinomma sp. aff. $H$. arachnoidale Hollande and Enjumet; Petrushevskaya and Kozlova, 1972, p. 515, pl. 9, fig. 4-7.

\section{Actinomma beroes (Ehrenberg) group (Plate 2, Figure 15)}

Haliomma beroes Ehrenberg, 1854, pl. 35B, fig. 19.

Sphaeropyle langii Dreyer, 1889, p. 13, fig. 54; Hulsemann, 1963, fig. 9; Kling, 1973, p. 634 , pl. 1, fig. 8, 9, pl. 13, fig. 6-8 (only).

Cromyechinus borealis (Cleve) Jörgensen, 1905, p. 117, fig. 35-37; Petrushevskaya, 1967, pl. 13, fig. 5-9; 1969a, pl. 1, fig. 1.

Prunopyle antarctica Dreyer, 1889, p. 24, fig. 75; Riedel, 1958, pl. 1, fig. 7,8 .

Cromyechimus antarctica (Dreyer) Petrushevskaya, 1967, p. 25, fig. 13, 14.

Cromyechinus bifasciculatus Dogel in Petrushevskaya, 1969b, pl. 3, fig. 4,5 .

\section{Actinomma buspinigerum (Hays}

Prunopyle buspinigerum Hays, 1965, p. 171, pl. 2, fig. 2.

The third shell is more extensive than in $A$. beroes group. The fourth shell is more delicate than that of $A$. beroes and $A$. tetrapyla. The outside radial spines are long.

\section{Actinomma tetrapyla (Hays)}

Prunopyle tetrapyla Hays, 1965, p. 172, pl. 2, fig. 5; Petrushevskaya, 1972a, pl. 2, fig. 2.

Sphaeropyle robusta Kling, 1973, p. 634, pl. 1, fig. 11, 12, pl. 6, fig. 913 , pl. 13, fig. 1-5.

The third shell is somewhat larger than in A. beroes. Robust fourth shell is characteristic.

\section{Genus HALIOMETTA Haeckel}

Haliometta Haeckel, 1887, p. 233; Campbell, 1954, p. 62; Petrushevskaya and Kozlova, 1972, p. 517. Type species Haliomma circumtextum Haeckel, 1887, pl. 28, fig. 7.

\section{Haliometta miocenica (Campbell and Clark)}

Heliosphaera miocenica Campbell and Clark, 1944a, p. 16, pl. 2, fig. 10-14.

Acanthosphaera sp. Hays, 1965, p. 169, pl. 2, fig. 1.

Haliometta miocenica group in Petrushevskaya and Kozlova, 1972, p. 517 , pl. 9, fig. 8,9 .

Miocene-Pliocene.

\section{Genus HEXACROMYUM Haeckel}

Hexacromyum Haeckel, 1881, p. 453; 1887, p. 201; Popofsky, 1913, p. 92; Campbell, 1954, p. 60; Strelkov, Khabakov, and Lipman, 1959, p. 436. Type species Hexacromyum elegans Haeckel, 1887, pl. 24, fig. 9.
(?)Echinomma Haeckel, 1881, p. 453; 1887, p. 257; Campbell, 1954, p. 66. =Echinommetta Haeckel, 1887, p. 257; Campbell, 1954. Type species Echinomma echinidium Haeckel, 1887, not illustrated.

Hexalonchusa Haeckel, 1887, p. 186; Campbell, 1954, p. 60. Type species Hexalonche philosophica Haeckel, 1887, pl. 22, fig. 4.

(?)Cubosphaera Haeckel, 1887, p. 202; Campbell, 1954, p. 58. Type species C. cubaxonia Haeckel, 1887, pl. 24, fig. 8.

Diagnosis: Haliommidae with four shells. The two inner are not always seen. The fourth shell is not always developed. All the shells are spherical, with a shell ratio of about $1: 2.5: 8: 10$. There are $12-16$ pores on half of the equator of the third shell and 6-10 outer radial spines.

Eocene(?)-Recent.

The genus Hexacromyum differs from Actinomma by the clearness of the third shell: in Hexacromyum its shape is fixed; the pores are round and nearly the same size; development of outer spines is also determined easier than in Actinomma.

\section{Hexacromyum sexaculeatum (Stöhr) group}

(Plate 2, Figures 3-5)

Haliomma sexaculeatum Stöhr, 1880, taf. 1, fig. 8.

(?)Hexalonche acetispina Vinassa de Regny, 1900, tav. 1, fig. 24.

Haliomma laeve Vinassa de Regny, 1900, tav. 1, fig. 31 .

Hexastylus simplex Vinassa de Regny sensu Martin, 1904, p. 459, pl. 130 , fig. 23.

Hexacontium subtile Carnevale, 1908, p. 17, tav, 2, fig. 15.

(?)Actinomma japonica Nakaseko, 1970, pl. 1, fig. 8.

Diameter of third shell is about $130 \mu-150 \mu$; outer spines are threebladed.

Oligocene-Miocene.

\section{Hexacromyum rara (Carnevale) group}

(Plate 2, Figures 1, 2)

Haliomma triactis Ehr. sensu Stöhr, 1880, p. 87, tav. 1, fig. 7 (non $H$. triactis Ehrenberg).

Hexalonche microsphaera Vinassa sens. Martin, 1904, p. 458, pl. 130, fig. 22.

Staurolonche rara Carnevale, 1908, p. 15, tav. 2, fig. 15.

Diameter of third shell is $100 \mu-110 \mu$; outer spines are three-bladed. Miocene.

\section{Hexacromyum delicatulum (Dogel) group}

(Plate 2, Figure 11)

Heliosoma delicatulum Dogel in Dogel and Reshethyak, 1952, fig. 2. Echinomma delicatulum (Dogel) Petrushevskaya, 1967, p. 22, fig. 11. Cenosphaera nagatai Nakaseko, sensu Hays, 1965, p. 165, pl. 2, fig. 6.

Diameter of third shell in Quaternary forms is about $90 \mu-120 \mu$, in Tertiary forms, $120 \mu-150 \mu$ (form I). It is possible that they were described as Haliomma infundibuliforme Stöhr, 1880, pl. 1, fig. 6. Outer spines are cylindrical (nearly always broken). About $11-12$ pores on a half of the equator of the third shell (in $H$. sexaculeatum they number about 14-15).

Miocene-Recent.

\section{Genus STYLOSPHAERA Ehrenberg}

Stylosphaera Ehrenberg, 1847b, p. 54; Haeckel, 1887; Campbell, 1954, p. 53; Strelkov, Khabakov, and Lipman, 1959, p. 433; Petrushevskaya and Kozlova, 1972, p. 520.=Stylosphaerella Haeckel, 1887, p. 135; Campbell, 1954, p. 53. Type species Stylosphaera hispida Ehrenberg, 1854, tav. 36, fig. 26.

Amphisphaerella Haeckel, 1887, p. 143; Campbell, 1954, p. 54. Type species Amphisphaera apollo Haeckel, 1887, not illustrated but looks like the specimen in Haeckel 1887, pl. 14, fig. 4.

Diagnosis: Haliommidae with four shells, the fourth is not always developed. The ratio of the shell's diameter (short axis) is 1:2.5:7.5:9. About $14-20$ pores on a half of the equator of the third shell. Two polar outer spines.

\section{Eocene-Pleistocene.}

\section{Stylosphaera minor Clark and Campbell group}

Stylosphaera minor Clark and Campbell, 1942, p. 16, pl. 1, fig. 13, 14; Petrushevskaya and Kozlova, 1972, p. 520, pl. 10, fig. 4.

The third shell is spherical. About 15 pores on a half of the equator of the third shell. Only two polar spines. 
Eocene-Oligocene. The Miocene forms of this group (referred to in Petrushevskaya and Kozlova, 1972, p. 520, pl. 10, fig. 8, as Stylosphaera sp. A) have up to 20 pores.

\section{Stylosphaera hispida Ehrenberg group}

(Plate 2, Figure 14)

Stylosphaera hispida Ehrenberg, 1854, tav. 36, fig. 26; Stöhr, 1880, p. 88 , taf. 1, fig. 12.

Amphisphaera spinosa Carnevale, 1908, p. 14, tav. 2, fig. 6 .

Stylosphaera angelina Campbell and Clark, 1944a, p. 12, pl. 1, fig. 1420; Petrushevskaya and Kozlova, 1972, p. 520, pl. 11, fig. 15-19.

Stylatractus universus Hays, 1970, p. 215, pl. 1, fig. 1, 2.

\section{Axoprunum angelinum (Campbell and Clark)}

Kling, 1973, p. 634, pl. 1, fig. 13-16, pl. 6, fig. 14-18; Ling, 1973, p. 777 , pl. 1, fig. 1-4.

The third shell is convex-concave in shape, with about 18 pores on a half of the equator. Besides two polar spines, some additional spines may be pronounced, especially in Miocene forms. There are forms with cylindrical (as in $S$. minor) polar spines as well as with threebladed polar spines (see Petrushevskaya, ?1972, pl. 1, fig. 3).

\section{Stylosphaera sp. C}

(Plate 2, Figures 12, 13)

Petrushevskaya and Kozlova, 1972, p. 520, pl. 11, fig. 5-7.

\section{Genus AMPHISPHAERA Haeckel emend.}

Amphisphaera Haeckel, 1881, p. 452, 1887, p. 142; Campbell, 1954, p. 54; Strelkov, Khabakov, and Lipman, 1959, p. 433.=Amphisphaeridium Haeckel, 1887, p. 142.=Amphisphaerantha Haeckel, 1887, p. 142; Campbell, 1954, p. 54. Type species Amphisphaera neptunus Haeckel, 1887, not illustrated, but looks like Stylatractus neptunus Haeckel, 1887, pl. 17, fig. 6.

Amphistylus Haeckel, 1881, p. 452, 1887, p. 145; Campbell, 1954, p. 54; Strelkov, Khabakov and Lipman, 1959, p. 433. Type species Amphistylus clio Haeckel, 1887, not illustrated but looks like the specimen in Haeckel, 1887, pl. 16, fig. 7.

Amphisphaerissa Haeckel, 1887, p. 144; Campbell, 1954. Type species Amphisphaera cronos Haeckel, 1887, pl. 17, fig. 5.

(?)Ellipsostylus Haeckel, 1887, p. 299; Campbell, 1954, p. 68.=Ellipsostyletta Haeckel, 1887, p. 319; Campbell, 1954, p. 68. Type species Ellipsostylus psittactus Haeckel, 1887, pl. 13, fig. 6.

Lithatractus Haeckel, 1887, p. 319; Campbell, 1954, p. 72; Strelkov, Khabakov, and Lipman, 1959, p. 440.=Lithatractara Haeckel, 1887, p. 319; Campbell, 1954, p. 72. Type species Stylosphaera fragilis Haeckel, 1887, pl. 16, fig. 3.

Lithatractona Haeckel, 1887, p. 319; Campbell, 1954, p. 72. Type species Lithatractus jugatus Haeckel, 1887.

Druppatractus Haeckel, 1887, p. 324; Campbell, 1954, p. 71.=Druppatractara Haeckel, 1887, p. 324; Campbell, 1954, p. 71.=Druppatractaria Clark and Campbell, 1942; Campbell, 1954, p. 71. Type species Druppatractus hippocampus Haeckel, 1887, p. 16, fig. 10, 11.

Stylatractus Haeckel, 1887, p. 328; Campbell, 1954, p. 73; Petrushevskaya and Kozlova, 1972, p. 519.=Stylatractura Haeckel, 1887, p. 328; Campbell, 1954, p. 73. Type species Amphistylus neptunus Haeckel, 1878 (Haeckel, 1887, pl. 17, fig. 6).

Xiphatractus Haeckel, 1887, p. 331; Campbell, 1954, p. 73.=Xiphatractara Haeckel, 1887, p. 331; Campbell, 1954, p. 73. Type species Xiphatractus armadillo Haeckel, 1887, pl. 17, fig. 11.

Xiphatractylis Haeckel, 1887 , p. 332; Campbell, 1954, p. 73. Type species Stylosphaera spinosa Ehrenberg, 1873, taf. 25, fig. 8.

Xiphatractium Haeckel, 1887, p. 334; Campbell, 1954, p. 73. Type species Stylosphaera radiosa Ehrenberg, 1873, pl. 25, fig. 5.

Diagnosis: Haliommidae with four shells, the fourth may be undeveloped. The second, third, and fourth (if present) shells are usually ellipsoidal. The shell ratio is about 1:2.5:5:6 (short axis). Pores on the third shell are rounded with about $5-10$ pores on half of the equator of the third shell. Two polar outer spines. Additional outer spines rare. Outer spines three-edged, without the deep furrows as in Spongosphaera (compare Plates 28 and 29). Polar spines (as a rule) are of differing lengths. The longest is about the same length as the main axis of the third shell (in Stylosphaera and in Axoprunum the spines are longer than the shell). The shortest spine may have a thickened mace on its end. The fourth shell (if present) is fused with the surface of the third shell and the huge pores of the third shell appear festooned (see Plate 28, Figure 5 or Petrushevskaya, 1967, fig. 15.) Protoxiphatractus Pessagno, 1973 seems to be the most ancient representative of the generic group Amphisphaera.

Late Mesozoic-Recent. The species of the genus were most numerous in Paleogene. They are rather variable and abundant in individuals.

\section{Amphisphaera santaennae (Campbell and Clark)}

$$
\text { (Plate 2, Figure 21) }
$$

Lithatractus santaennae Campbell and Clark, 1944a, p. 19, pl. 2, fig. 20-22.

Stylatractus santaennae (Campbell and Clark) Petrushevskaya and Kozlova, 1972, p. 520, pl. 11, fig. 10.

Miocene.

\section{Amphisphaera radiosa (Ehrenberg) group (Plate 2, Figures 18-20)}

Stylosphaera radiosa Ehrenberg, 1854, p. 256; 1875, taf. 24, fig. 5 . (?)Druppatractus agostnellii Carnevale, 1908, p. 20, tav. 3, fig. 10. Lithatractus santaennae pusillus Campbell and Clark, 1944a, p. 19, pl. 2, fig. 23-25.

Stylatractus radiosus (Ehr.) Petrushevskaya and Kozlova, 1972, p. 520.

The smaller spine is variable and nearly undeveloped. The fourth shell is absent. About nine pores on a half of the equator of the third shell.

Eocene-Early Miocene.

\section{Amphisphaera spinulosa (Ehrenberg) group}

(Plate 15, Figure 8)

Stylosphaera spinulosa Ehrenberg, 1873, p. 259, 1875, pl. 15, fig. 8. (?)Xiphatractus trochus Haeckel, 1887, p. 129, pl, 13, fig. 10.

Stylosphaera goruna Sanfilippo and Riedel, 1973, p. 521, pl. 1, fig. 2022, pl. 25, fig. 9, 10.

Eocene.

\section{Amphisphaera sp. aff. Stylatractus neptunus Haeckel} (Plate 28, Figures 2-6)

Stylatractus neptunus Haeckel, Riedel, 1958, p. 226, pl. 1, fig. 9. Stylatractus sp. Petrushevskaya, 1967, p. 30, fig. 15, fig. 32, III.

(?)Xiphatractus radiosus (Ehrenberg) Haecker, 1908, p. 442, pl. 84, fig. 588.

It is difficult to say if they are the same species and the pores really overgrow in the ontogeny (as it was suggested by Petrushevskaya, 1967 ), or the two species exist-one with the large pores (Plate 28, Figure 5), and the second with numerous smaller pores (Plate 28, Figures 2,6). The spines in both forms are three-edged at the base, but without deep furrows (Plate 29, Figure 4). The spines are solid, without any internal tube, but some evidence of the process for the formation of the silica layers in the growth of the spine may be seen (Plate 28 , Figures 3,4$)$. The species seem to be most closely related to $A$. santaennae.

Quaternary.

\section{Amphisphaera dixyphos (Ehrenberg)}

(Plate 2, Figure 17)

Haliomma dixyphos Ehrenberg, ?1844, p. 83; 1854, taf. 22, fig. 31. The outer shell is nearly spherical.

Oligocene.

\section{Genus AXOPRUNUM Haeckel}

Axoprumum Haeckel, 1887, p. 298; Campbell, 1954, p. 68; Hays, 1965, p. 170; Petrushevskaya and Kozlova, 1972, p. 520. Type species Axoprunum stauraxonium Haeckel, 1887, pl. 46, fig. 4.

Diagnosis: Differs from Stylosphaera and Amphisphaera by the outer spines: in Axoprumum only polar spines are present. All internal rods joining the second and the third shells (except two polar) are intended to be situated in the equatorial plane. In the points, where they touch the third shell, small pits exist. Polar spines are as long as in Stylosphaera. The number of the pores on half of the equator of the third shell is not as constant as in Stylosphaera and Amphisphaera. In different species they number up to about 20 . 


\section{Axoprunum liostylum (Ehrenberg) group}

(Plate 2, Figure 22)

Stylosphaera liostylus Ehrenberg, 1873, p. 259; 1875, pl. 25, fig. 7. Axoprunum liostylum (Ehr.) Petrushevskaya and Kozlova, 1972, p. 521, pl. 10, fig. 3 .

\section{Axoprunumpierinae (Clark and Campbell) group}

Sanfilippo and Riedel, 1973, p. 488, pl. 1, fig. 6-12; pl. 23, fig. 3. About 13 pores on a half of the equator of the third shell. Polar spines are cylindrical.

Eocene-Oligocene.

\section{Genus STOMATOSPHAERA Dreyer}

Stomatosphaera Dreyer, 1889; Campbell, 1954. Type species Stomatosphaera amphistoma Dreyer, 1889 , p. 209, fig. 30.

Diagnosis: Cortical shell is very thick-walled with rather small pores, elongated with one or two pyloms on the poles. Radial spines present only as internal rods (not external spines). One or two internal medullar shells of delicate structure (?). The diagnosis is only provisional. A reinvestigation of the type species is necessary.

\section{Stomatosphaera (?) haackei (Dreyer) group}

(Plate 1, Figure 9)

(?) Prunopyle prunoides Dreyer, 1889, fig. 25.

(?) Prunopyle haackei Dreyer, 1889, fig. 26.

(?)Prunopyle petrosa Dreyer, 1899, p. 207, fig. 38.

(?)Cenellipsis bergontianus Carnevale, 1908, p. 19, pl. 3, fig. 6 .

(?)Prunilum exogonatum Principi, 1909, p. 10, pl. 1, fig. 26.

Actinosphaera (?) haackei (Dreyer) Dumitrica, 1972, pl. 19, fig. 5-9.

Dumitrica (1972) describes three types of the internal shells similar to those in Lonchosphaera spp. (Plate 17, Figures 3-15). There is no reason to place the species in question into Actinosphaera Hollande and Enjumet, 1960. = Haliomilla Haeckel, 1887 (type species Haliomma capillaceum Haeckel, 1862, pl. 23, fig. 2). The latter species has a different cortical shell.

Oligocene-Miocene.

\section{Family RHIZOSPHAERIDAE Haeckel}

Rhizosphaerida Haeckel, 1881, p. 455, 1887, p. 209; Hollande and Enjumet, 1960, p. 106.

Diagnosis: Haliommoidea with the first shells confused in the central "spongy" meshwork; diameter, $100 \mu-150 \mu$. After $50 \mu-70 \mu$ this central mass is surrounded by a number of peripheral skeletal layers or shells which may be confused in the peripheral spongy meshwork. Central mass and peripheral skeletal meshwork connected by numerous (more than 20) radial spines which may go outside of the skeleton. The whole skeleton is generally more than $200 \mu$, and spherical.

Mesozoic(?)-Recent.

Genus RHIZOSPHAERA Haeckel emend. Hollande and Enjumet

Rhizosphaera Haeckel, 1860, p. 840; 1887, p. 283; Popofsky, 1913, p. 110; Campbell, 1954, p. 68; Hollande and Enjumet, 1960, p. 106. Type species Rhizosphaera leptomita Haeckel, 1862, pl. 25, fig. 810.

(?)Conosphaera Haeckel, 1881, p. 451; 1887, p. 221; Campbell, 1959, p. 437; Strelkov, Khabakov, and Lipman, 1959, p. 437. Type species Conosphaera platycomus Haeckel, 1887, pl. 12, fig. 3.

Spongoplegma Haeckel, 1881, p. 455; 1887, p. 89; non Campbell, 1954, p. 50; non Hollande and Enjumet, 1960, p. 104. Type species Spongoplegma antarcticum Haeckel, 1887, not illustrated.

Actinommura Haeckel, 1887, p. 255; Campbell, 1954, p. 66. Type species Actinomma capillaceum Haeckel, 1887, pl. 26, fig. 6 .

Outer radial spines short (usually broken).

Oligocene(?)-Recent.

\section{Rhizosphaera antarcticum (Haeckel) group}

Spongoplegma antarcticum Haeckel, 1887, p. 89; Hays, 1965, p. 165, pl. 1, fig. 1; Nakaseko, 1971a, p. 51-57.

Cladococcus aquaticus Popofsky, 1908, p. 214, pl. 23, fig. 3, 4.

Diploplegma banzare Riedel, 1958, p. 233, pl. 1, fig. 3, 4.

Diploplegma (?) aquatica (Popofsky) Petrushevskaya, 1967, p. 18, pl. 9,
The most ancient forms of the group have better defined pores on the peripheral shell than Quaternary forms. These Oligocene specimens (form E) look like Haliomma entactinia Ehrenberg, 1875, pl. 26, fig. 4. The specimen similar to the ancient type was illustrated by Petrushevskaya, 1967, pl. 10, fig. 2. Spongoplegma variabilium Nakaseko, 1971a, pl. 1, fig. 1-3, also seems to have many ancient characteristics.

\section{Family CENTROCUBIDAE Hollande and Enjumet}

Centrocubidae Hollande and Enjumet, 1960, p. 120.

Diagnosis: Haliommoidea with a cubic first shell. It is small and composed of short straight rods. Eight main (about $50 \mu$ in diameter) radial spines come from that microsphere. A second medullar shell may be present. No spongy central mass, as in Rhizosphaeridae. About $50 \mu-70 \mu$ away, the peripheral latticed or spongy shell is present. Radial spines may go outside.

Octodendron spp.

(Plate 39, Figures 5, 6)

Octodendron sp. Hays, 1965, p. 170, pl. 1, fig. 4.

In the middle Miocene the peripheral (outside) spongy shell is very rough and robust.

\section{Family MACROSPHAERIDAE Hollande and Enjumet}

Macrosphaerida Hollande and Enjumet, 1960.

Diagnosis: No axoplast as a rule in center of central capsule or in nucleus, but each axoneme has its own "axoplast" near the outer surface of the nucleus (Cryptoaxoplastidie). The first shell, if present, is a macrosphere, and has a diameter exceeding $50 \mu$. As a rule it does not penetrate the nucleus. The peripheral skeleton may be latticed or spongy and is very large. The family name is not useful because there is no genus Macrosphaera to be included in the family. The author prefers to use this preliminary name because it is not clear that the following species are typical Cryptoxoplastides.

\section{Cenosphaera(?) oceanica Clark and Campbell group}

(Plate 1, Figures 12, 13; Plate 31, Figure 5)

(?)Cenosphaera oceanica Clark and Campbell, 1945, p. 7, pl. 1, fig. 4.

Only the cortical shell was seen, and is thick-walled. There are $35-40$ irregular pores on half of the equator. Shell diameter is $320 \mu-370 \mu$.

Oligocene-Miocene.

Remarks: The author does not think this species is closely related to the species typical to Cenosphaera, but the proper genus in which to include this species is not clear.

\section{Thecosphaerella (?) ptomatus Sanfilippo and Riedel group}

(Plate 1, Figures 1, 2)

Thecosphaerella ptomatus Sanfilippo and Riedel, 1973, p. 521, pl. 3, fig. 14-18, pl. 26, fig. 2.

It is difficult to indicate the generic implement of this species (as well as the family or group). It may belong in Hexastyliodea or in Macrosphaeridae (Cryptoaxoplastides) Hollande and Enjumet. The first shell is about $50 \mu$. About $15-25$ pores on a half of the equator of the cortical shell. Outer radial spines are weak, numerous, of variable position, and very probably hollow.

Paleocene-Eocene. In the Antarctic, up to latest Oligocene. It seems likely that some of Actinommura's species in Petrushevskaya and Kozlova, 1972, p. 519, pl. 9, belong in this group. The generic name $\mathrm{Ac}$ tinommura can not be used for all these species because the type species of Actinommura has Rhizosphaerid's construction.

\section{Superfamily LITHELIOIDEA Haeckel, emend.}

Lithelida Haeckel, 1862 , p. 515 , 1881 , p. $464 ; 1887$, p. 688 ; Riedel, 1967a.

Larcoidea Haeckel, 1881, p. 463; 1887, p. 599; Popofsky, 1908, p. 145; Deflandre, 1953 , p. 416.

Pylodiscida Haeckel, 1887, p. 561, part.

Diagnosis: In Recent forms the axoplast was not found. In the center of the skeleton there is a small microsphere $(15 \mu \times 9 \mu-13 \mu)$. The microsphere (the first shell) may be asymmetrically arranged. In some forms studied by Kozlova (?1967) the construction of this shell appeared to be constant and of a particular type. The second shell may be irregular or ellipsoidal, with rather large pores (or gates) in the 
walls, which looks as if it is incomplete. It may be subdivided into lobes (or kamera) by radial spines going from the first shell. The distance between the first and the second shell is about $10 \mu$. The third and subsequent shells are similar to the second shell. The number of the shells is different in various families. Asymmetry of the shells, very often subdivided into lobes, gives the impression of spiral constructions.

Paleozoic-Recent.

Family LITHELIIDAE Haeckel, emend.

Lithelida Haeckel, 1862 , p. 515 ; 1881 , p. 464 ; 1887, p. 688 ; Riedel, $1967 \mathrm{a}$.

Diagnosis: No less than 5, often up to 10 or more shells (layers of the small cells). Shell walls are almost without gates. The distance between shells (layers) is no more than $15 \mu-25 \mu$. Radial spines are very numerous. If the walls of a shell between radial rods are not curved outward, there will not be pronounced lobes and the structure will be of the pseudoaulophacoid-type (Plate 3, Figure 12). If the walls form lobes, there will not be a regular structure (Plate 3, Figures 9, 11, 12).

\section{Genus OMMATODISCUS Stöhr}

Ommatodiscus Stöhr, 1880, p. 115; Haeckel, 1887, p. 500; Campbell, 1954, p. 92. Type species Ommatodiscus haeckeli Stöhr, 1880, taf. 6, fig. 7 .

The skeleton is a slightly flattened ellipsoid with about 10 shells. The distance between innermost shells is less than twice the distance between peripheral shells. The pseudoaulophacoid structure is very definite (Plate 32, Figures 1-3). The pseudoaulophacoid meshwork cells are rather large. The peripheral cells may be covered by the latticed plates (Plate 32, Figures 6,7). The most peripheral shells or layers of the pseudoaulophacoid cells may be developed only on the two poles of the skeleton, not near the equatorial plane. The skeleton in the Oligocene-Miocene forms is covered with gown. The gown is open on the one pole, but there is no definite pylom.

\section{Ommatodiscus haeckeli Stöhr group}

(Plate 3, Figures 9, 12, 13; Plate 32, Figures 1-8)

Ommatodiscus haeckeli Stöhr, 1880, p. 115, taf. 6, fig. 7.

(?) Perichlamidium radiatum Vinassa de Regny, 1900, tav. 1, fig. 46. (?)Lithelius sp. Sachs, ?1973, pl. 2, 3, fig. n.

No less than 10 shells (or layers of the pseudoaulophacoid cells); definite pseudoaulophacoid structure. Radial spines go outside the skeleton, but usually are broken and hollow.

Late Eocene-Pliocene. The late Miocene individuals (Plate 3, Figures 9,13 ) may have a poorly defined pseudoaulophacoid structure, thus, they are similar to Lithocarpium polyacantha. The latest Miocene specimens have a more pseudoaulophacoid structure with the smaller cells.

\section{Genus LITHOCARPIUM Stöhr, emend.}

Lithocarpium Stöhr, 1880, p. 97; Haeckel, 1887, p. 1172; Campbell, 1954. Type species Lithocarpium pyriforme Stöhr, 1880, pl. 3, fig. 10.

As a rule the skeleton is ellipsoidal with definite pylom-tube. About ten shells are concentrical (or form a dense spiral). The distance between a pair of these shells (layers) is less than $10 \mu$. Incomplete layers are developed only near the poles. The distance between these shells is up to $15 \mu-30 \mu$. Pseudoaulophacoid structure cannot be distinguished: shells are lobated. The shells is covered with gown.

\section{Lithocarpium polyacantha (Campbell and Clark) group} (Plate 3, Figures 6-8; Plate 29, Figure 6)

(?)Porodiscus bassanii Principi, 1909, p. 12, tav. 1, fig. 31. Larnacantha polyacantha Campbell and Clark, 1944a, p. 30, pl. 5, fig. 4 (only).

Prunopyle titan Campbell and Clark, sensu Hays, 1965, p. 173, pl. 2, fig. 4; Bandy, Casey, and Wright, 1971, pl. 1, fig. 7-9 (only).

The peripheral incomplete layers are rather thick-walled and definite. The surface of the gown has irregular pores. Radial spines are common.

Latest Eocene-Miocene.
Lithocarpium fragilis (Stöhr)

(Plate 4, Figures 2-4)

Ommatodiscus fragilis Stöhr, 1880, p. 116, taf. 6, fig. 10.

(?) Ommatodiscus multipora Principi, 1909, p. 13, pl. 1, fig. 36

(?)Larnacantha polyacantha Campbell and Clark,?1944, pl. 5, fig. 5, 6 (only).

Incomplete peripheral layers can not be distinguished. Skeleton consists of dense central spiral, surrounded by fine irregular meshwork. The surface is irregular and covered with latticed gown. Small external spines may be present.

Oligocene-Miocene.

\section{Lithocarpium titan (Campbell and Clark) \\ (Plate 4, Figure 5)}

Prunopyle titan Campbell and Clark, ?1944, pl. 3, fig. 1-3. non Prunopyle titan sensu Hays, 1965, or sensu Bandy, Casey, and Wright, 1971.

External surface regular, without spines. Internal structure difficult to see, but Kozlova (personal communication) indicates that it consists only of an irregular meshwork.

Californian Miocene; rare in the sub-Antarctic Oligocene.

Remarks: It is better to remove this species from Prunopyle Dreyer because the type species of the latter genus $P$. pyriformis Dreyer, 1889, fig. 19, has a different skeletal construction (rather similar to Amphisphaera radiosa group).

\section{Lithocarpium monikae n. sp.}

(Plate 4, Figures 6-10; Plate 30, Figures 1-7)

Outer gown with meshes $5 \mu-10 \mu$ in diameter. The diameter of entire skeleton about $150 \mu-250 \mu$. The central mass (or spiral?) looks very similar to that in $L$. fragilis although L. monikae differs from L. fragilis. The latter have no pronounced radial spines (or rods), and the space between the central mass and the outer gown in $L$. fragilis is filled with irregular meshes (Plate 4 , Figures $3,4,7$ ). In $L$. monikae the construction is similar to that in Rhizosphaeridae: there are radial spines connecting central mass and external layer. L. monikae differs from Rhizosphaerids by having another external shell (or gown) with pylom. L. monikae resembles Plegmosphaera maxima Haeckel by the thin outer skeletal layer (the difference is the absence of the internal mass in P. maxima). In the same way L. fragilis is similar to Plegmosphaera exodictyon Haeckel (1887, pl. 18, fig. 8). They have a nearly identical thick peripheral skeleton composed of irregular meshes (the difference is the absence of the internal mass in P. exodictyon. It is difficult to say if there is real connection between Lithocarpium species and Plegmosphaerids. L. (?) monikae differs from $L$. titan by having a thinner, less regular, even spongy outer surface of the skeleton, and straight radial spines. The species is named after Monique CachonEnjumet in acknowledgment of her great contribution to the knowledge of radiolarian euplasmatic structures. Holotype No. 62243 from Site 280, Cores 3, 4. Description is based on 26 specimens.

\section{Genus LITHELIUS Haeckel}

Lithelius Haeckel, 1862, p. 519; 1887, p. 693; Campbell, 1954, p. 99. =Lithospira Haeckel, 1887, p. 693; Campbell, 1954, p. 99. Type species Lithelius spiralis Haeckel, 1862, taf. 28, fig. 6, 7.

Diagnosis: Skeleton subspherical or ellipsoidal; 6-10 shells; spiral construction can be observed. Pseudoaulophacoid structure is not pronounced. The last turn of the spiral touches the preceding turn, thus the skeleton becomes complete. There is no special gown or pylom.

Neogene(?)-Recent.

Lithelius (?) nautiloides Popofsky

(Plate 3, Figures 1, 3, 5; Plate 33, Figures 3, 4)

Lithelius nautiloides Popofsky, 1908, p. 230, pl. 27, fig. 4 (only); Riedel, 1958, p. 228, pl. 2, fig. 3 (only); Petrushevskaya, 1967, p. 53, fig. 27; 28,$1 ; 29,1$.

About six shells (or turns of the spiral). Each turn is 1.5 times higher than the preceding turn. This is different from $L$. spiralis group, where the turns remain of nearly the same breadth. Characteristic for $L$. (?) nautiloides are small pyramids surrounding the radial spines in the 
walls of the shells. The difference from L. spiralis is so great that the generic name of the species under consideration is questionable.

\section{Lithelius nautiloides (Form $\mathbf{P}$ )}

(Plate 3, Figures 1, 3)

Very similar to the typical $L$. nautiloides, but the Miocene specimen have had elongated skeletons rather similar to the skeletons of Lithocarpium polyacantha (Plate 3, Figures 1, 3, 9). The late Eoceneearly Oligocene specimens have larger skeletons with more numerous turns of the spiral.

\section{Lithelius hexaxyphophorus (Clark and Campbell)}

Stylosphaera hexaxyphophora Clark and Campbell, 1942, p. 28, fig. 4, $5,7,11,12$.

Lithelius hexaxyphophorus (Clark and Campbell) Sanfilippo and Riedel, 1973 , p. 522 , pl. 7 , fig. $7-9$, pl. 26 , fig. 6,7 .

Differs from some very regular specimens of Pylospira sp. A by the complete gown (outer shell)

Eocene.

\section{Lithelius foremanae $f$. "small"}

(Plate 3, Figure 4)

Lithelius foremanae Sanfilippo and Riedel, 1973, pl. 26, fig. 5 (only). Pyramids the same as in the typical $L$. (?) foremanae and $L$. nautiloides, but only the central part of the skeleton ( 4 inner shells) are developed.

Late Eocene-Oligocene.

\section{Lithelius (?) sp. E}

(Plate 3, Figure 2)

Nearly spherical skeleton with double dense spiral. Characteristic for the subantarctic Eocene.

\section{Genus PYLOSPIRA Haeckel}

Pylospira Haeckel, 1887; Campbell, 1954. Type species Pylospira octopyle Haeckel, 1887.

The skeleton is ellipsoidal; 5-7 shells (or spiral turns). Each turn 1.52 times higher than the preceding turn. Radial spines are pronounced, and go outwards from the shell (usually broken). The last turn of the spiral touches the preceding one, making the skeleton complete and closed. The pylom is rarely seen. It seems likely that Lithelius(?) nautiloides, belongs in this genus. It is difficult to indicate the difference between Pylospira, Tholospira Haeckel, 1887, and Larcopyle Dreyer, 1889. It is also difficult to determine what Spiremaria Kozlova, ?1960 (type species Spiremaria decens Kozlova, ?1960) represents by itself.

Pylospira (?) sp. A

(Plate 3, Figures 10, 11)

\section{(?)Spiremaria fragosa Kozlova, ?1960, p. 318, pl. 4, fig. 4a,b.}

Only four spiral turns are complete. The others (peripheral) are presented by incomplete kameras on the skeleton's poles, thus the skeleton is elongated. The distance between the shells (= the breadth of the spiral turns) is about $15 \mu$ in the central part, and about $35 \mu$ on the periphery. Late Oligocene specimens in the Antarctic sediments have a very irregular surface, untypical for Pylospira, but in the Eocene samples from Hole $280 \mathrm{~A}$, Core 10-5 the specimens have the gown. The outer skeletal surface is the same type as some Lithocarpiums (Plate 3, Figures 8, 9.). These specimens are referred to as "Form A."

There is another form, "Form B," which has a very regular, symmetrical shell. The central part is of the same type as in Lithelius (?) foremanae, but two "polar wings" (caps ?) are present as in Phorticium species. This "Form B" occurs in the subantarctic Eocene (Hole $280 \mathrm{~A}$, Cores 6, 10, Hole 281, Core 14). Kozlova (personal communication) supposes Spiremaria fragosa to be nearly of the same construction. However, no collection is available for comparison.

\section{Pylospira sp. L}

(?)Pylospira octopyle Haeckel, 1887, p. 49, fig. 9.

(?)Larcopyle butschlii Dreyer, 1889, fig. 70.

(?)Tholospira sp. Kruglikova, 1969, pl. 4, fig. 18.

Tholospira sp. 3 Sachs, ?1973, pl. 24, fig. i, h.
Differs from Pylospira sp. A by having a more regular spiral with increasing chambers. The last "caps" (?) are present only on one pole. The gown is common. The radial spines are usually broken.

Pliocene.

Remarks: The specimen is very similar to Pylospira sp. L which are common in the sediments of $\mathrm{Y}$ and $\mathrm{T}$ Zones in the subantarctic. It is possible that they were referred to as Prunopyle titan.

\section{Genus PHORTICIUM Haeckel}

Phorticium Haeckel, 1881, p. 964; 1887, p. 709; Campbell, 1954, p. 100. Type species Phorticium pylonium Haeckel, 1887, pl. 49, fig. 10.

\section{Phorticium clevei (Jörgensen) group}

Phorticium pylonium Haeckel, Cleve 1899, p. 31, pl. 3, fig. 2; Jörgensen, 1905, p. 120, fig. 42-45; Riedel, 1958, p. 220, pl. 2, fig. 5. Octopyle octostyle Haeckel, forma minor Jörgensen, ?1900, p. 64. Tetrapylonium clevei Jörgensen, ?1900, p. 64.

Cromyacarpus quadrifarius Hck., Popofsky, 1908, p. 219, pl. 33, fig. 4. Phorticium clevei (Jö̈gensen) Petrushevskaya, 1967, p. 58, fig. 32-34.

The first four turns of the spiral are complete and represent a definite compact central body about $100 \mu$ in diameter. The fifth turn of the spiral is wide (breadth about $50 \mu$ ), so that the entire skeleton is about $200 \mu$ in diameter. The last turn is incomplete, with greater gates, typical for Phorticidae and Pylonidae. It seems probable that this species in the Antarctic could originate from Pylospira species by means of the reducing of the peripheral parts of the skeleton.

Miocene-Recent.

\section{Superfamily SPONGODISCOIDEA Haeckel}

Lithocyclida Ehrenberg, ?1847, p. 214

Spongurida Haeckel, 1862, p. 447.

Spongodiscida Haeckel, 1862, p. 460; Riedel, ?1967, p. 295.

Trematodiscida Haeckel, 1862, p. 491.

Porodiscida Haeckel, 1881, p. 459, 1887, p. 481; Riedel, ?1967, p. 296.

Stylodictyida Haeckel, 1881, p. 459.

Euchitonida Haeckel, 1881, p. 459.

Spongopylida Dreyer, 1889, p. 87.

Pseudoaulophacidae Riedel, ?1967; Pessagno, 1972, p. 273; 1973, p. 56.

Hagiasteridae Riedel, Pessagno, 1971, p. 19.

Phaseliformidae Pessagno, 1972, p. 273.

Diagnosis: In recent forms the axoplast was not found, but Hollande and Enjumet (1960) indicate that the euplasmatic structures are rather similar to those of Periaxoplastidies (Hexastylioidea). In the center of the skeleton there is a small microsphere $(5 \mu-18 \mu)$. This first shell in some forms is of a particular constant construction, similar to that of Lithelioidea (Kozlova, ?1967). The second shell may be irregular or flattened. The walls of the second and subsequent shells are complete without gates. Radial spines are very numerous but rarely form external spines. The second and subsequent shells may be flattened: the distance between two shells (layers) in the equatorial plane is more than the distance between these shells measured in the perpendicular axis. In the direction of this axis, shells (layers of the cells) may be confused, or even undeveloped (especially the peripheral ones). These incomplete layers represent the rings of Porodiscida by themselves. If the shells and the radial rods connecting the shells are regularly arranged, the skeletal structure is pseudoaulophacoid (the same as in Lithelioidea); the distance between two such layers is $5 \mu$ $10 \mu$. If the disposition of radial and transverse rods is irregular, the structure is spongy; the distance between the two layers is about $8 \mu$ $25 \mu$. Very often the two types of the structures are present in the same individual, thus it is difficult to divide Spongodiscidae from Pseudoaulophacidae on the basis of the skeletal structure (Plates 34, 37; Plate 36, Figures 5, 6). The difference between Spongodiscoidea and Lithioidea is not significant if compared to Ommatodiscus and Spongopyle (only the number of the shells [layers] is more in Spongopyle, the distance between shells being less). These genera may be regarded as primitive in both superfamilies. In Lithelioidea the tendency of reducing the number of the shells seems to exist. The distance between them become more, the walls of the shells become incomplete, but with large gates (Pylonidae, Phorticidae). In Spongodiscoidea the number of shells, rings, and kamera, on an average, is more than in Lithelioidea. The evolutionary tendencies in Spongodiscoidea are different from Lithelioidea.

Paleozoic-Recent. 


\section{Family SPONGODISCIDAE Haeckel}

Spongodiscida Haeckel, 1862, p. 460; 1887, p. 461; Campbell, 1954, p. 93; Riedel, ?1967, p. 295.

Spongotrochida Haeckel, 1881, p. 461; 1887, p. 575; Campbell, 1954, p. 94 .

Spongopylida Dreyer, 1889; Campbell, 1954, p. 94.

Pseudoaulophacidae Riedel, ?1967, part; Pessagno, 1971, p. 19.

The skeleton is in the shape of a disk or lens. It is thick: on the periphery it is composed of more than one layer of chambers (cells) or meshes. (These chambers or meshes represent by themselves the space between the shells subdivided by means of radial rods or spines.) In the center of the skeleton the shells are completely concentric. On the periphery of the disk there may be thicker and thinner parts (Plate 34, Figure 4), but no real arms and patagium exist. (Real arms and patagium are composed of different skeletal meshes.) These thicker and thinner parts are composed of the same chambers. Pseudoaulophacoid and spongy arrangement of the chambers can be observed in the same lineage.

Paleozoic(?)-Recent

\section{Genus SPONGODISCUS Ehrenberg}

Spongodiscus Ehrenberg, 1854, p. 237; Haeckel 1881, p. 461; 1887, p. 576; Campbell 1954, p. 93; Strelkov, Khabakov, and Lipman, 1959, p. 449; Petrushevskaya and Kozlova, 1972, p. 528.

Spongodisculus Haeckel, 1887, p. 576; Campbell, 1954, p. 93. Type species Spongodiscus resurgens Ehrenberg, 1854, pl. 35B, V, fig. 16.

Spongopyle Dreyer, 1889, p. 118; Campbell, 1954, p. 94. Type species Spongopyle setosa Dreyer, 1889, pl. 4, fig. 97, 98.

Diagnosis: Spongodiscidae with very small and rather regular chambers. Pylom (if present) has spines or even tubes. Surface gown may be present. Radial spines go from the center of the disk in all directions.

Cretaceous(?)-Recent.

Spongodiscus resurgens Ehrenberg osculosa (Dreyer)

(Plate 5, Figure 11; Plate 36, Figures 1-4)

Spongopyle osculosa Dreyer, 1889, p. 42, fig. 99, 100; Riedel, 1958, p. 226, pl. 1, fig. 12; Casey, 1971, pl. 1, fig. 14.

Spongodiscus osculosus Petrushevskaya, 1967, p. 42, fig. 20, 21, 22; Petrushevskaya and Kozlova, 1972, p. 528, pl. 21, fig. 34.

Disk, $100 \mu-160 \mu$ in diameter. Radial spines do not go outside the gown (except the pylom).

Miocene-Recent.

\section{Spongodiscus craticulatus (Stöhr)}

(Plate 5, Figures 9, 10)

Spongotrochus craticulatus Stöhr, 1880, p. 118, pl. 6, fig. 12.

Diameter of the disk is about $200 \mu-280 \mu$. Radial spines go outside the gown.

Miocene.

\section{Genus SCHIZODISCUS (Dogel)}

Schizodiscus Dogel; Dogel and Resetnyak, 1952, p. 8; Petrushevskaya, 1967, p. 42; non Petrushevskaya and Kozlova, 1972, p. 528. Type species Schizodiscus disymmetricus Dogel; Dogel and Resetnyak, 1952, (see Petrushevskaya and Kozlova, 1972, pl. 21, fig. 14).

Diagnosis: Skeleton in the shape of a disk or lens or in a shape like the planet Saturn: there may be one thickened part in the center. The skeleton chambers are irregular (spongy-type). There are no radial spines going through the skeleton, but on the lens margin small byspines may be present. The gown may be developed not on the lens surface, but in the distance between these by-spines (Plate 5, Figures 1 , 2 ). The pylom is seen only in the disks more than $250 \mu$ in diameter. The pylom are without spines in a shape of a simple funnel.

Miocene-Recent.

\section{Schizodiscus favus (Ehrenberg); maxima (Popofsky)}

(Plate 5, Figures 6, 7; Plate 34, Figures 1, 2)

Spongodiscus favus Ehrenberg, var, maxima Popofsky, 1908, p. 226, pl. 26, fig. 4. Spongodiscus (?) setosus Dreyer sensu Petrushevskaya, 1967 , p. 39, fig. 20, 23, 24, only (non $S$. setosa Dreyer, 1889).

Lens diameter about $200 \mu-250 \mu$; Central globe about $120 \mu-150 \mu$ in diameter. Pylom's funnel is rarely seen. No gown, by-spines unknown, and no radial spines.
Pliocene(?)-Recent.

Remarks: Spongopyle setosa Dreyer, 1889, (fig. 97, 98) is very much the same as Spongodiscus craticulatus Stöhr, but does not have gown at the equatorial margin.

\section{Schizodiscus disymmetricus Dogel Group}

(Plate 5, Figures 1-4)

Schizodiscus disymmetricus Dogel; Dogel and Resetnyak, 1952, p. 8, Petrushevskaya and Kozlova, 1972, pl. 21, fig. 14.

(?)Spongodiscus resurgens Ehr. sensu Stöhr, 1880, p. 111, pl. 6, fig. 11. The lens is about $400 \mu$ in diameter, central thickness, about $150 \mu$. Pylom is common. Gown and by-spines are rarely seen.

Miocene-Pliocene in Antarctic; up to the Recent in the North Pacific.

\section{Schizodiscus codrant n. sp.}

(Plate 38, Figures 1-7)

Skeleton in a form of the regular disk, but with the recess in the middle of each flattened surface. It may be named a concave lens. From a recess short spines arise (by-spines?), which support the gown. The latter forms a small lid above the recess. Gown with small pores and similar to the gown in Spongodiscus resurgens osculosus, where the middle part of the gown is also supported by the spines. Sch. codrant differs from $S$. resurgens osculosus by having larger and more rough and irregular spongy meshes. Sch. codrant differs from Sch. favus maxima and from Sch. disymmetricus by the concave form of its main disk. The form of the disk in Sch. codrant is very similar to that in Orbiculiforma vacaensis Pessagno, 1973 (compare pl. 17, fig. 1-6 with Plate 38, Figure 7 in the present paper). The description is based on 57 specimens from Site 278, (Cores 27 and others). Holotype No. 62244 in the Marine Department of the Zoological Institute. The name means "coin" in Latin.

\section{Genus SPONGOTROCHUS Haeckel}

Spongotrochus Haeckel, 1860 , p. $844 ; 1862$, p. $462 ; 1887$, p. 585 ; Campbell, 1954, p. 94; Strelkov, Khabakov, and Lipman, 1959, p. 451; Petrushevskaya and Kozlova, 1972, p. 528.=Spongotrochiscus Haeckel, 1862 , p. $463 ; 1887$, p. 585 ; Campbell, 1954, p. 94. Type species Spongotrochus brevispinus Haeckel, 1862, pl. 27, fig. 4-5. Stylotrochus Haeckel, 1862 , p. 464; 1887, p. 583; Sanfilippo and Riedel, 1973, p. 525; non Campbell, 1954, p. 94.=Stylotrochiscus

Haeckel, 1887, p. 583. Type species Stylotrochus arachnius Haeckel, 1862.

Diagnosis: Skeleton in the shape of a lens when covered by gown. If there is no gown, the central thickened mass of the skeleton and the flattened peripheral disk can be seen. The central part is not a globe (as in Schizodiscus favus maxima), but it may be flattened or even have recess (Plate 35, Figures 5,6). The skeleton chambers are irregular, of spongy-type. They are about three (or even more) times less in the very center than on the periphery. Radial spines are numerous all over the skeleton. They are stronger in the equatorial plane. The pylom in a shape of a simple funnel is common in large disks.

Cretaceous-Recent.

Remarks: Typical Spongotrochus species are similar to Pseudoaulophacus lenticulatus (White) in nearly all characteristics except the more regular arrangement of the chambers in P. lenticulatus. The difference between Spongotrochus and Spongotripus Haeckel is the same as between Pseudoaulophacus lenticulatus and Alievium Pessagno; in Spongotripus and Alievium the number of the spines is constant.

Spongocyclia Haeckel, 1862 (p. 469, type species Spongocyclia cyclodes Haeckel, 1862, pl. 28, fig. 1), or Stylosphongium Haeckel, 1881 (type species Spongotrochus scutella Haeckel, 1887, not illustrated), or Stylospongia Haeckel, 1862 (p. 473, type species Stylospongia huxleyi Haeckel, 1862) belong the species having the largest chambers in the central part of the skeleton (not on the periphery, as in Spongotrochus). These central chambers in Spongocyclia form spirals. Species of that type are known as Spongodiscus phrix Sanfilippo and Riedel, Spongodiscus pulcher Clark and Campbell, and Cretaceous Spongodiscidae (Petrushevskaya and Kozlova, 1972, pl. 5, pl. 13) and others. It is possible that in the Cretaceous the genera Spongotrochus and Stylocyclia (or Stylospongia?) were closely related. There is no reason to regard Stylotrochus and Stylospongia as synonyms: their type species (Stylotrochus arachnius and Stylospongia huxleyi) are quite different. 


\section{Spongotrochus glacilialis Popofsky group}

(Plate 5, Figure 8; Plate 35, Figures 1-6)

Spongotrochus glacialis Popofsky, 1908, p. 228, pl. 27, fig. 1, pl. 28, fig. 2; Riedel, 1958, p. 227, pl. 2, fig. 1, 2; Hulsemann, 1963, p. 18, fig. 10, 11; Petrushevskaya, 1967 , p. 43 , pl. 21 , fig. $1-4$, pl. 22 , fig. $1-5$.

(?)Trochodiscus echiniscus Haeckel, 1887; Cleve, 1899, p. 34, pl. 4, fig. 4; Bogorov, ?1946, p. 338.

(?)Trochodiscus helioides Cleve, 1899; Schroder, 1909, p. 40, fig. 25; Bogorov, ?1946, p. 338.

(?)Stylotrochus sol Campbell and Clark, ?1944, p. 28, pl. 4, fig. 3 (only).

Schizodiscus stylotrochoides Dogel; Dogel and Resetnyak, 1952; Petrushevskaya, 1967, p. 47, fig. 23.

Spongotrochus beringianus Dogel; Petrushevskaya, 1967, p. 47, fig. 24, 25.

The equatorial margin is rounded. An SEM reinvestigation of all members of the group from various areas is necessary.

Miocene-Recent.

\section{Spongotrochus cruciferus (Clark and Campbell)}

(Plate 5, Figure 5)

Spongasteriscus cruciferus Clark and Campbell, 1945, pl. 4, fig. 4, 6; Sanfilippo and Riedel, 1973, pl. 11, fig. 14-17.

The outline of the disk shows four festoons, but no arms and patagium.

Eocene.

\section{Genus PERICHLAMIDIUM Ehrenberg}

Perichlamidium Ehrenberg, ?1847, p. 54; Haeckel, 1884, p. 498; Campbell, 1954, p. 90. Type species Perichlamidium praetextum Ehrenberg, ?1847, 1854, pl. 22, fig. 20.

Diagnosis: Disk-shaped skeleton; transverse and the radial rods are rather regular in the center and quite irregular on the periphery. On the periphery the chambers are 3-10 times greater than in the center, biggest on the margin. Radial spines are well developed. The gown on the surfaces of the disk is known as porous plates. Pylom is unknown.

Remarks: Perichlamidium differs from Stylochlamidium (type species Stylochlamidium asteriscus Haeckel, 1887, pl. 41, fig. 10) by having a very thick disk, composed of many layers of chambers in the central part of the disk (Plate 39, Figures 3, 4; Plate 40, Figure 4). Perichlamidium differs from Spongotrochus by having concentrical chambered rings on the periphery of the disk. Perichlamidium differs from Spongocyclia (or Stylospongia) by having the biggest chambers arranged spirally on the periphery (not in the center) of the disk. Perichlamidium differs from Stylospyra Haeckel, 1862, (p. 515, type species Stylodictya dujardini Haeckel, 1862, pl. 29, fig. 9, 10) by having a more complete equatorial margin, with large chambers and gown.

\section{Perichlamidium praetextum Ehrenberg group} (Plate 6, Figure 10)

Flustrella praetexta Ehrenberg, ?1844.

Perichlamidium praetextum Ehrenberg, 1854, pl. 22, fig. 20.

(?)Discospira accrescens Stöhr, 1880, p. 114, pl. 6, fig. 5 .

(?)Stylodictya biporata Vinassa de Regny, 1900, pl. 2, fig. 5 .

(?)Stylotrochus nitidus Sanfilippo and Riedel, 1973, p. 525, pl. 13, fig. 9-11, only.

(?)Perichlamidium scutaeforme Campbell and Clark, ?1944, p. 24, pl. 3, fig. 14 only.

Perichlamidium limbatum Ehrenberg

(Plate 6, Figure 11; Plate 39, Figures 1-4)

Perichlamidium limbatum Ehrenberg, ?1847; 1854, pl. 22, fig. 20; Haeckel, 1887, p. 514.

Differs from $P$. praetextum by having fewer regular central chambers and greater dimensions. Forms with reduced number of chambered rings (Plate 6, Figure 12) have existed and seem to be related with the forms given on the Plate 6, Figures 2, 3.

Perichlamidium sp. Q

(Plate 16, Figure 7)

Perichlamidium sp. Petrushevskaya, 1972a, pl. 1, fig. 4.

Characteristic for the subantarctic Pleistocene. No spiral or concentric ring is seen and the chambers are quite irregular.

\section{Genus CIRCODISCUS Kozlova}

Circodiscus Kozlova; Petrushevskaya and Kozlova, 1972, p. 526. Type species Trematodiscus microporus Stöhr, 1880, pl. 4, fig. 17.

(?)Plectodiscus Kozlova; Petrushevskaya and Kozlova, 1972, p. 526. Type species Porodiscus circularis Clark and Campbell, 1945, pl. 11 , fig. 2, 6, 10 .

Diagnosis: Spongodiscidae with reduced number of chambers. The chambers from the very central ones are of Lithelid-type. Usually the first three central shells are completely concentric. The more peripheral shells are not complete, but represent by themselves chambered rings. The gown is confused with the walls of the chambers. No strong external radial spines. Pylom is an opening in the marginal wall.

Remarks: The difference between Trematodiscus microporus and Porodiscus circularis at first glance is only in the number of shells (or chambered rings). However, Kozlova has demonstrated (Kozlova, ?1967; Petrushevskaya and Kozlova, 1972, pl. 19, fig. 5, 11) that in Trematodiscus microporus the walls of the second shell come outside on the flat surfaces of the disk, while in Porodiscus circularis the second shell is enclosed into the third shell, and only the walls of the third will come out on the flat surfaces of the disk. There are also some differences in the wall construction. The author is unable to decide in which genus, Circodiscus or Plectodiscus, to include the species.

It seems likely that Perichlamidium limbatum Ehr., Stylotrochus (?) alveatus Sanfilippo and Riedel, Porodiscus (?) charlestonensis Clark and Campbell, Porodiscus (?) bergontianus Carnevale, Porodiscus (?) circularis Clark and Campbell, Trematodiscus (?) ellipticus Stöhr, and Trematodiscus (?) microporus Stöhr are the subsequent stages of the same lineage, going from some Spongotrochus species. The number of the meshes become less, the size of the meshes become larger.

\section{Porodiscus (?) bergontianus Carnevale}

Porodiscus bergontianus Carnevale, 1908, p. 23, pl. 4, fig. 2. Plectodiscus bergontianus (Carnevale) Kozlova; Petrushevskaya and Kozlova, 1972, p. 526, pl. 19, fig. 13.

More and narrower rings than Porodiscus circularis Clark and Campbell. Fewer and wider rings in Circodiscus ellipticus (Stöhr) and C. microporus (Stöhr) than in Porodiscus circularis Clark and Campbell. In Porodiscus (?) bergontianus Carnevale the central chambers are bigger and more distinct than in Perichlamidium limbatum group, where the central part of the skeleton is nearly spongy.

\section{Circodiscus (?) circularis (Clark and Campbell)}

Porodiscus circularis Clark and Campbell, 1942, p. 42, pl. 11, fig. 2, 6, 10.

Porodiscus uralicus Lipman, 1960, p. 86, pl. 11, fig. 9-11. Porodiscus durus Moksyakova, ?1970, p. 146, pl. 2, fig. 8.

Circodiscus circularis (Clark and Campbell) Kozlova; Petrushevskaya and Kozlova, 1972, p. 526, pl. 19, fig. 9-12.

The central construction is ellipsoidal; 3-5 rings (elongated) surrounding that construction (less than in Porodiscus (?) bergontianus). Rather variable species.

Remarks: The species name is preoccupied (Ommatodiscus circularis Carnevale seems to belong in the same genus Circodiscus). But $O$. circularis Carnevale seems to be a synonym of Circodiscus ellipticus (Stöhr).

\section{Circodiscus ellipticus (Stöhr) group}

(Plate 6, Figures 1-6)

Trematodiscus ellipticus Stöhr, 1880, p. 108, pl. 4, fig. 16.

(?)Perichlamidium irregulare Vinassa de Regny, 1900, pl. 2, fig. 7.

(?)Ommatodiscus circularis Carnevale, 1908, pl. 4, fig. 9; Dumitrica, 1968, pl. 1, fig. 2.

(?)Porodiscus vinassai Principi, 1909, p. 12, pl. 1, fig. 32.

Slightly ellipsoidal second shell is $30 \mu-40 \mu$ in diameter. The breadth of the chambers in the third layer (the breadth of the first distinct chamber ring) is about $10 \mu$; in the fourth shell about $25 \mu$. In the ring the breadth of the chambers may be variable: in typical forms (Plate 6, Figures $1-3$ ) it is $35 \mu-50 \mu$, but this shell may be reduced and stand out from the previous shell at the distance of only $10 \mu$ (Plate 6, Figure 4). The fourth ring (the last) is quite variable, the chambers of that shell are $5 \mu-25 \mu$ broad. The pylom is on the longer side of the ellipsoid, not on the shorter, narrower, as in Porodiscus microporus (Stöhr) polipora Vinassa de Regny, 1900 (pl.2, fig. 7), or in Carnevale's (1908, pl. 4, fig. 7-9) species.

Miocene. 


\section{Circodiscus microporus (Stöhr) group}

Trematodiscus microporus Stöhr, 1880, p. 108, pl. 4, fig. 17.

Circodiscus microporus (Stöhr) Kozlova; Petrushevskaya and Kozlova, 1972, p. 526, pl. 19, fig. 1-7.

Xiphospira sp. cf. X. circularis (Clark and Campbell) sensu Kling, 1973 , p. 635 , pl. 7 , fig. 17 , only.

In DSDP Leg 29 specimens the central construction plus two cammered rigs (see Petrushevskaya and Kozlova, 1972, pl. 19, fig. 9) were common. The outer equatorial rim is delicate, not robust. The pylom can be seen.

Miocene.

Spirema (?) sp. Kling

(Plate 16, Figure 6)

Spirema sp. Kling, 1973, pl. 7, Fig. 23-25.

The dimensions and the pore arrangement are the same as $C$. microporus, but the rings are not complete and the spiral is seen. The pylom may be present on one side.

Miocene.

\section{Family STYLODICTYIDAE Haeckel}

Stylodictyida Haeckel, 1881, p. 459; 1887; Campbell, 1954, p. 92.

The skeleton is in the shape of a disk composed of one layer of chambers (Plate 40, Figure 4). Four main radial spines, arranged in the equatorial plane, divide the skeleton into four sectors. All the shells (except the first one or two) are incomplete. In each ring (incomplete shell) there are four main chambers. They may be subdivided into a number of chambers of means of additional radial spines. All chambers are in the same plane. The breadth of the rings (and their chambers) increase from the center to the periphery. No arms and patagium.

Cretaceous-Recent.

\section{Genus XIPHOSPIRA Haeckel}

(?)Staurodictya Haeckel, 1881, p. 460; 1887, p. 506; non Campbell, 1954, p. 92; Strelkov, Khabakov and Lipman, 1959, p. 445. Type species Staurodictya medusa Haeckel, 1887, pl. 42, fig. 3.

Xiphospira Haeckel, 1887, p. 504; Campbell, 1954, p. 92; non Sanfilippo and Riedel, 1973, p. 526. Type species Xiphodictya staurospira Haeckel, 1887, pl. 42, fig. 12.

(?)Tholodiscus Kozlova; Petrushevskaya and Kozlova, 1972, p. 525. Type species Stylodictya ocellata Ehrenberg, 1875, pl. 23, fig. 7. Stylodictyidae with four very distinct chambers in each ring. In fact, there are no real rings, but a spiral, similar to that of Tholonidae. The skeleton is subdivided into four sectors. In a sector each subsequent chamber is 2-3 times higher than the previous one.

Cretaceous-Oligocene.

\section{Xiphospira ocellata (Ehrenberg)}

Stylodictya ocellata Ehrenberg, 1875, pl. 23, fig. 7.

Staurodictya ocellata (Ehr.) Haeckel, 1887, p. 508.

Tholodiscus ocellatus (Ehrenberg) Kozlova; Petrushevskaya and Kozlova, 1972, p. 525, pl. 18, fig. 1, 2.

Porodiscus (or Trematodiscus?) has the type species very similar to some species of Stylodictya (compare Stylodictya stellata), Plate 6, Figure 9, and Porodiscus concentricus in Petrushevskaya and Kozlova, 1972, pl. 18, fig. 11). In Porodiscus there are not four main spines and sectors. It seems likely Porodiscus is closely related to some Pseudoaulophids and Spongotrochus species (see Cretaceous species in Petrushevskaya and Kozlova, 1972, pl. 5, fig. 6-9, 11, 12; or Porodiscus charlestonensis Campbell and Clark), not to Stylodictya. It seems likely that in Stylodictyidae the tendency existed to diminish the ring width and increase the number of rings (Xiphospyra ocellatus, $X$. splendens, Stylodictya targaeformis). On the other hand it is possible that Stylodictya stellata arose from Stylochlamidium spp. by reducing the marginal ring (the porous plates of the last ring), very much the same as in Spongodiscids, Stylospyra dujardini (Haeckel) very probably arose from Perichlamidium spp.

\section{Genus STYLODICTYA Ehrenberg}

Stylodictya Ehrenberg, ?1847, p. 54; Haeckel, 1887, p. 509; Campbell, 1954, p. 92; Strelkov, Khabakov, and Lipman, 1959, p. 445; Petrushevskaya and Kozlova, 1972, p. 525.=Stylodictyon Haeckel,
1887; Campbell, 1954, p. 92. Type species Stylodictya gracilis Ehrenberg, 1854, pl. 34, fig. 28.

Diagnosis: Stylodictyidae with the skeleton being without a distinct subdivision into four sectors, although four main radial spines and four chambers in the first ring are seen in subsequent rings, the chambers are about 1.5 times wider.

Eocene-Recent.

\section{Stylodictya gracilis Ehrenberg}

(Plate 7, Figure 12)

Stylodictya gracilis Ehrenberg, 1854, pl. 34, fig. 28; 1873, p. 527; 1875 , pl. 23, fig. 3.

Very few additional spines (about 4 , going from the third through the subsequent rings). Chamber width in the second ring is about $18 \mu$ $22 \mu$. There are $4-5$ pores on the width of the chamber (or of a ring). Paleogene.

\section{Stylodictya targaeformis (Clark and Campbell) (Plate 6, Figures 7, 8)}

Staurodictya targaeformis Clark and Campbell, 1942, p. 43, pl. 3, fig. 6.

Stylodictya targaeformis (Clark and Campbell) Petrushevskaya and Kozlova, 1972, p. 526, pl. 18, fig. 10.

Four to five additional spines rising from the third ring. The number of the spines increases from ring to ring. The chamber width in the second ring is about $5 \mu$ and in the third ring about $7 \mu ; 7-9$ rings total; $2-3$ pores on the width of a ring.

Eocene-Oligocene.

\section{Stylodictya stellata Bailey group}

(Plate 6, Figure 9)

Stylodictya stellata Bailey, 1856, p. 5, pl. 1, fig. 20; Kruglikova, 1969, pl. 4 , fig. $9,10$.

Stylodictya validispina Jörgensen, 1905, p. 119, pl. 10, fig. 40; Petrushevskaya, 1967 , p. 33 , pl. 17, fig. 4,5 .

Xiphospira sp. cf. X. circularis (Clark and Campbell) sensu Kling, 1973, p. 635 . pl. 2 , fig. 1-3, pl. 7, fig. $11,13,14$ (only).

Even more additional spines than in $S$. targaeformis. The chamber width is about $8 \mu$ in the second ring and nearly the same for the third ring. Five to six rings; $2-3$ pores on the width of a ring.

Miocene-Recent. The Pliocene specimens are larger than those of the Quaternary.

Remarks: This species has no close connection Porodiscus circularis (Clark and Campbell).

\section{Stylodictya rosella Kozlova}

Stylodictya rosella Kozlova; Petrushevskaya and Kozlova, 1972, p. 526 , pl. 18 , fig. 9.

Differs from $S$. targaeformis by the irregularity of the arrangement of the rings and spines, and by the thickness of the rim.

Eocene-Oligocene.

\section{Family HELIODISCIDAE}

Heliodiscida Haeckel, 1881, p. 457, 1887, p. 444.

The first three shells are of a peculiar construction.

\section{Heliodiscus sp. A}

(Plate 1, Figure 16)

Few pores on the third shell; few spines (distinct and cylindrical); no girdle on the equatorial margin.

\section{Family SPONGURIDAE Haeckel, emend.}

Spongurida Haeckel, 1862, p. 447; 1887, p. 339; Campbell, 1954, p. 73 , part; Pessagno, 1973, p. 57.

Ommatocampida Haeckel, 1887, p. 392; Campbell, 1954, p. 76.

(?)Spongodruppida Haeckel, 1887, p. 348; Campbell, 1954, p. 74; non Pessagno, 1973, p. 75.

Monaxoniinae Campbell, 1954, p. 76.

Phaseliformidae Pessagno, 1972, p. 273.

Diagnosis: Spongodiscoidea with cylinder-shaped skeleton with two arms. As a rule an arm may have a spine in itself. In the center of the skeleton the shells (layers) are complete and concentric. On the 
poles of the skeleton the layers are incomplete. The arms and the center of the skeleton may be surrounded by the patagium. The meshes (chambers) of the patagium are larger than the chambers in the arms. The patagium may be covered with a gown with very small pores. One of the arms has a pylom.

Mesozoic-Recent.

Remarks: Pessagno amended the diagnosis of Spongodruppida of Haeckel and included Cavaspongidae in Spongodruppidae. In addition, the construction of Spongodruppa, which must be further investigated, might be quite different from Cavaspongia. The difference between two groups, Pessagno's Phaseliforma and Parvicuspis, and Spongurus, Ommatogramma, and Spongocore seems to be significant (Plate 37).

\section{Genus OMMATOGRAMMA Ehrenberg}

Ommatogramma Ehrenberg, ?1860; Haeckel, 1887, p. 519; Campbell, 1954, p. 88. Type species Ommatogramma naviculare Ehrenberg, 1872 , pl. 6, fig. 7.

Spongurus Haeckel, 1862, p. 465; 1887, p. 343; Campbell, 1954, p. 74. Type species Spongurus cylindricus Haeckel, 1862, pl. 27, fig. 1.

Spongocore Haeckel, 1887, p. 345; Campbell, 1954, p. $74 .=$ Spongocorina Haeckel, 1887, p. 345; Campbell, 1954, p. 74. Type species Spongocore velata Haeckel, 1887, not illustrated.

Spongocorisca Haeckel, 1887, p. 345 ; Campbell, 1954, p. 74. Type species Spongocore puella Haeckel, 1887, pl. 48, fig. 6.

Diagnosis: Sponguridae with the skeleton composed in its central part as well as in the arms, of a spongy or even pseudoaulophacoid meshwork arranged in many layers. If concentric shells (rings) can be seen, the many chambers are small $(4 \mu-8 \mu)$. The arms on the poles may be thicker than the central part of the skeleton. The patagium and gown may be present. Radial spines (if present) are weak but numerous which is the difference from Spongosphaera Ehrenberg (type species $S$. pachystyla Ehrenberg Plate 29, Figures 1-3), families Spongosphaerida Haeckel, Spongostylida Haeckel, and Archaeospongopruninae Pessagno (Plate 29, Figures 1-3).

Ommatogramma dumitrica n. sp.

(Plate 7, Figure 3; Plate 37, Figures 4, 5)

The main skeleton body is about $50 \mu$ broad in its central part, about $75 \mu$ broad in its arms and $200-250 \mu$ long. The central part of the skeleton and the base of the arms are surrounded by a patagium (as by a muff), about $100 \mu-150 \mu$ long. The outlines of the main body of the skeleton and the layers of the patagium are X-shaped. The radial spines are weak. The pylom is in one of the arms. Gown with small pores covers only the patagium. Differs from Spongurus pylomaticus Riedel (Plate 7, Figure 4) by: smaller dimensions, the outline of the skeleton, the more delicate gown, and the presence of patagium. The intermediate species (?), similar to the species in question and to $S$. pylomaticus was illustrated by Kruglikova (1969). O. dumitrikii differs from Spongocore puella Haeckel, Spongocore lata Campbell and Clark and some other similar species by not having a thickened central part of the main skeletal body, and thus having a different skeletal outline.

Description is based on 34 specimens from the Site 278, Cores 27-29. Holotype No. 62245 in Zoological Institution of the Academy of Sciences of the USSR. The species is named after Paulian Dumitrica, a well known radiolarian investigator.

\section{Spongurus (?) pylomaticus Riedel \\ (Plate 7, Figure 4; Plate 37, Figure 7)}

Spongurus pylomaticus Riedel, 1958, p. 226, pl. 1, fig. 10, 11; Petrushevskaya, 1967 , p. 32 , fig. $16,1,2$.

Cylindrical skeleton is up to $225 \mu$ long, up to $125 \mu$ broad. No patagium. Gown is common and covers the entire skeleton.

Pliocene-Recent.

Remarks: Difference from $O$. dumitrica is so great that they seem to belong in different genera. $S$. (?) pylomaticus needs a special (new) genus.

\section{Amphymenium (?) splendiarmatum Clark and Campbell}

(Plate 7, Figure 1; Plate 37, Figures 1-3)

Amphymenium splendiarmatum Clark and Campbell, 1942, p. 46, pl. 1,

fig. 14; Sanfilippo and Riedel, 1973, pl. 11, fig. 8 (only).

The Antarctic Oligocene specimens have nearly the same construction and dimensions as tropical Eocene ones, but the spine in the arm is less developed and the arm itself is a bit broader to the end (to the pole). The patagium is small.

Eocene-Oligocene.

In the Antarctic late Oligocene forms existed which in the central part of the skeleton were very similar to Amphymenium (?) splendiarmatum, but the ends of their arms were nearly the same as in $\mathrm{Om}$ matogramma, O. amphistylium group, or in $O$. dumitrica. It seems likely that the lineage Amphymenium (?) splendiarmatum $\rightarrow$ Ommatogramma sp. (Petrushevskaya and Kozlova, 1972, pl. 21, fig. 11) $\rightarrow O$. dumitrica existed. The meshes increase in number and become irregular.

\section{SPONGURIDAE gen. sp. D}

(Plate 4, Figure 1)

Lithelid (or pseudoaulophacoid) internal cylinder with radial spines. At $10 \mu-25 \mu$ from the cylinder, thin gown is present (very characteristic).

\section{Family ARTISCIDAE Haecke}

Artiscida Haeckel, 1881 , p. 462 ; 1887 , p. 354 ; Campbell, 1954 , p. 74 ; Deflandre, 1953, p. 421; Riedel, ?1967, p. 294; Petrushevskaya and Kozlova, 1972, p. 521.

Cyphinida Haeckel, 1881 , p. $462 ; 1887$, p. 359.

Zygartida Haeckel, 1881, p. 462; 1887, p. 392; Campbell, 1954, p. 76. Panartida Haeckel, 1887, p. 375; Campbell, 1954, p. 75.

Zygocampida Haeckel, 1887, p. 392; Campbell, 1954, p. 76.

Diagnosis: Spongodiscoidea with an elongated skeleton consisting of the central part; the first shell, $15 \mu-20 \mu$ in diameter; the second shell, about $45 \mu$ in diameter; and the third (so-called) twin-shell. The second shell may be flattened, the third is always elongated and very often has the equatorial construction. The rods connecting the second and the third shells are placed near the equatorial plane. The arms (polar columns or capes) are very much the same as in Sponguridae. The patagium surrounding the central part of the skeleton (as a muff) may also be developed. The main difference from Sponguridae is the peculiar and constant construction of the first three shells in Artiscidae (in Sponguridae the dimensions of the first three shells vary even in the same lineage).

The author does not believe that Artiscidae arose from the forms illustrated by Petrushevskaya and Kozlova (1972, pl. 12, fig. 1) but believes them to have descended from Sponguridae.

\section{Genus CANNARTUS Haeckel}

Cannartus Haeckel, 1881 , p. 462 , 1887 , p. 358 ; Campbell, 1954 , p. 74 ; Riedel and Sanfilippo, 1970, p. 520; Petrushevskaya and Kozlova, 1972, p. 521.

Artiscidae with narrow spongy columns (arms).

\section{Cannartus prismaticus Haeckel}

(Plate 7, Figures 5-7)

For synonymy, see Riedel and Sanfilippo,?1970. Cannartus with very narrow columns and without any hint to the capes.

Ommatartus (?) or Cannartus antepenultimus (Riedel and Sanfilippo). Ommatartus antepenultimus Riedel and Sanfilippo 1970, p. 521, pl. 14, fig. 4 .

The columns (arms) are broader than in C. prismatium but very much the same as in $C$. laticonus. The capes are indistinct.

\section{Cannartus laticonus Riedel group}

(Plate 7, Figures 5-7, 9-10)

The twin shell has tubercula. The narrow polar columns show a trace of caps on the base and radial spines on the ends. Antarctic specimens have irregular, variable twin shell outline. They are similar to Cannartiscus marylandicus Martin in Bandy, Casey and Wright, 1971, pl. 1, fig. 5 .

\section{Cannartus mammiferus (Haeckel)}

The twin-shell with tuberculae. Spongy columns are narrow (without the caps). The radial spines can be seen. 


\section{Genus ASTROMMA Ehrenberg}

Astromma Ehrenberg, 1847 b, p. 54; Campbell, 1954, p. 74 Petrushevskaya and Kozlova, 1972, p. 522. Type species Astromma enthomocora Ehrenberg, ?1847; 1854, pl. 22, fig. 32.

Polar columns are as broad as the twin shell. The polar caps are pressed closely to the twin shell.

\section{Astromma petterssoni (Riedel)}

Cannartus petterssoni in Riedel and Sanfilippo, 1970, pl. 14, fig. 3; Petrushevskaya and Kozlova, 1972, p. 522, pl. 12, fig. 5.

\section{Astromma hughesi (Campbell and Clark}

Ommatocampe hughesi Campbell and Clark, 1944a, p. 23, pl. 3, fig. 12. Ommatartus hughesi (Campbell and Clark) Riedel and Sanfilippo, 1970 , p. 520.

Astromma hughesi (Campbell and Clark) Petrushevskaya and Kozlova, 1972, p. 522, pl. 12, fig. 4.

The polar columns are chambered and are not spongy.

\section{Order NASSELLARIA}

Suborder CYRTIDA

Cyrtida Haeckel, 1862, p. 280; Petrushevskaya 1971a, p. 984; 1971b, p. 56.

Nassellarians with the cephalis having no real sagittal ring. The cephalis may be large $(35 \mu-150 \mu$ in the average dimension), or smaller $(15 \mu-25 \mu)$. In both sizes nearly the same constructions exist (the parallel series may be followed, Figure 10). If the cephalis is small, the other segments are well developed. If the cephalis is large, from the other segments, the thorax may be fully developed. Very often the dimensions of the entire skeleton are about $200 \mu$. The monaxon heteropolar differentiation of the skeleton (the disposition of the internal spines, the mouth of the shell, etc.) are easily seen.

\section{Superfamily EUCYRTIDIOIDEA Ehrenberg}

Eucyrtidina Ehrenberg, ?1847; Petrushevskaya, 1971a, p. 985; 1971b, p. 166; Petrushevskaya and Kozlova, 1972, p. 535.

Cephalis is small (as a rule no more than $25 \mu-30 \mu$ in its average dimension); it is usually also very small compared to the whole skeleton. After the thorax comes the abdomen and generally some other segments.

\section{Family EUCYRTIDIIDAE Ehrenberg}

Eucyrtidiidae Ehrenberg, Petrushevskaya, 1971a, p. 985; 1971b, p. 215; Petrushevskaya and Kozlova, 1972, p. 545.

Three segmented skeletons are common, the abdomen being the largest; sometimes the subdivision into the thorax and abdomen may be indistinct, or the thorax may be larger than abdomen. The abdomen may be subdivided into secondary segments. Cephalis small, not constant (Figure 10, IV, V, VIII, IX).

\section{Subfamily THEOCAMPINAE $\mathrm{n}$. subfam.}

Artostiobridae group A Petrushevskaya and Kozlova, 1972, p. 536, part.

Cephalis small with highly arranged branches (a) and with more or less developed additional parts of the cephalis, usually with great pore (or small tube) in the postcephalic part. Apical horn (or tube) is weak, if present. The larger skeleton segment is the abdomen, separated from the thorax by the internal ring as a rule. Thoracic pores are in checkerboard order. Abdominal pores are in transverse rows as a rule. No well-developed feet.

Cretaceous-Paleogene. Rare in Neogene and Quaternary.

Remarks: The author is not sure if Artobotys Petrushevskaya and Rhapalosyringium Foreman are typical for this subfamily, but Phormocyrtis does not belong in the subfamily Theocampinae.

\section{Genus THEOCAMPE Haeckel s. s.}

Theocampe Haeckel, 1887, p. 1422; Campbell, 1954, p. 134, part.; Petrushevskaya and Kozlova, 1972, p. 537. Type species Dictyomitra ehrenbergii Zittel, 1876, pl. 2, fig. 5.

The pores on the abdomen are in transverse (horizontal) rows but sometimes longitudinal rows are very distinct.

Cretaceous-Paleogene.
Remarks: Lithocampium sp. A. described by Foreman as Buryella characteristic for the Paleocene deposits (Plate 8, Figure 23) seems to descend from Theocampe. Eusyringium spp. and the related forms (Plate 8, Figures 16, 20-22) differ by their conical cephalis, and by the longitudinal rows of the pores. Paleogene Phormocyrtis sp. (Plate 8, Figure 19) differs from Theocampe not only by the pore arrangement, but also by the shell proportions (the thorax being larger).

\section{Theocampe minuta (Clark and Campbell)}

(Plate 10, Figure 7; Plate 26, Figures 5-6)

Lithocampe minuta Clark and Campbell, 1942, p. 93, pl. 9, fig. 17. Cephalis plus the thorax are about $40 \mu$ long; thorax about $45 \mu$ wide. The abdomen is same size as the cephalothorax. About six pores in a half of the row (on a half of the equator of the shell).

Eocene-Oligocene.

\section{Theocampe elizabethae (Clark and Campbell)}

Lithomitra elizabethae Clark and Campbell, 1942, p. 92, pl. 9, fig. 18; Petrushevskaya and Kozlova, 1972, pl. 22, fig. 11, 12.

Eucyrtidium microteca Ehrenberg, sensu Petrushevskaya, 1971b, pl. 92 , fig. 6, 7.

Differs from Th. minuta by the elongated cylindrical abdomen. Differs from the Paleocene species (Plate 10, Figure 6) by not having additional internal rings in the abdomen.

Eocene-Oligocene. Widely distributed species-group.

\section{Genus ARTOSTROBUS Haeckel}

Artostrobus Haeckel, 1887, p. 1481; Campbell, 1954, p. 140; Petrushevskaya 1971b, p. 212.=Artostrobulus Haeckel, 1887, p. 1481; Campbell, 1954, p. 140. Type species Cornutella annulata Bailey, 1856, fig. 5 .

The Cretaceous (Petrushevskaya, 1971b, pl. 92, fig. 3) and the Paleocene (Plate 10, Figure 1) forms of the genus Artostrobus were very much similar to Lithocampana (Plate 11, Figure 1). The main difference is in the constricted (not widely conical) shape of the skeleton. However, the Cretaceous and Paleocene forms of Artostrobus are very similar to Theocampe species (the same cephalis, the same outline of the shell, similar pores), but they differ from Theocampe by not having a ring to separate thorax and the abdomen. The Neogene-Quaternary species Artostrobus annulatus (type species of the genus) differs from Theocampe, and from the ancient $A r$ tostrobus sp. Cr. having the cephalis based on the "pedestal" (the upper part of the thorax narrow, elongated, without pores).

The "pedestal" with the same construction is known in Lychnocaniidae (Plate 12, Figures 2, 3), in Neosciadiocapsidae, and in some other Eucyrtidioidea. The pedestal was illustrated by Petrushevskaya (?1967, p. 101, fig. 56, and 1971b, fig. 92, I, and fig. 114, IV, V) and by Foreman (1973, fig. 4). This pedestal is similar to the neck of some cephalises (compare Figures 1, 2, and 3 on Plate 12), but the pedestal doesn't have an $M B$ and other spines in its base. The neck of the cephalis always has these spines. In the case of $A$. annulatus it is possible to follow the lineage Artostrobus sp. $\mathrm{Cr}$. $\rightarrow$ A. pusillum, $\rightarrow$ A. annulatus, when the pedestal arose.

Although the cephalis of $A$. annulatus is rather untypical for Theocampidae, the genus Artostrobus is placed among Theocampids. Also, there is no separation into a thorax and an abdomen, and the skeleton is two segmented (not three-segmented).

Genus Artostrobus may be connected with Cretaceous Acidnomelos Foreman, 1968, and some other Cretaceous and Paleogene dicyrtids.

\section{Artostrobus pusillum (Ehrenberg)}

(Plate 26, Figures 1, 2)

Eucyrtidium pusillum Ehrenberg, 1873, p. 232; 1873, pl. 11, fig. 6; Petrushevskaya, 1971b, pl. 92, fig. 5 .

Very similar to $A$. annulatum but without a constriction or slender "pedestal" between the cephalis and the thorax. It differs from $\mathrm{Ar}$ tostrobus $\mathrm{cp}$. Cr. by the larger and fewer pores.

Oligocene.

\section{Artostrobus annulatus (Bailey)}

(Plate 10, Figures 4, 5)

Well-known species. From the lowest Miocene to Recent. 

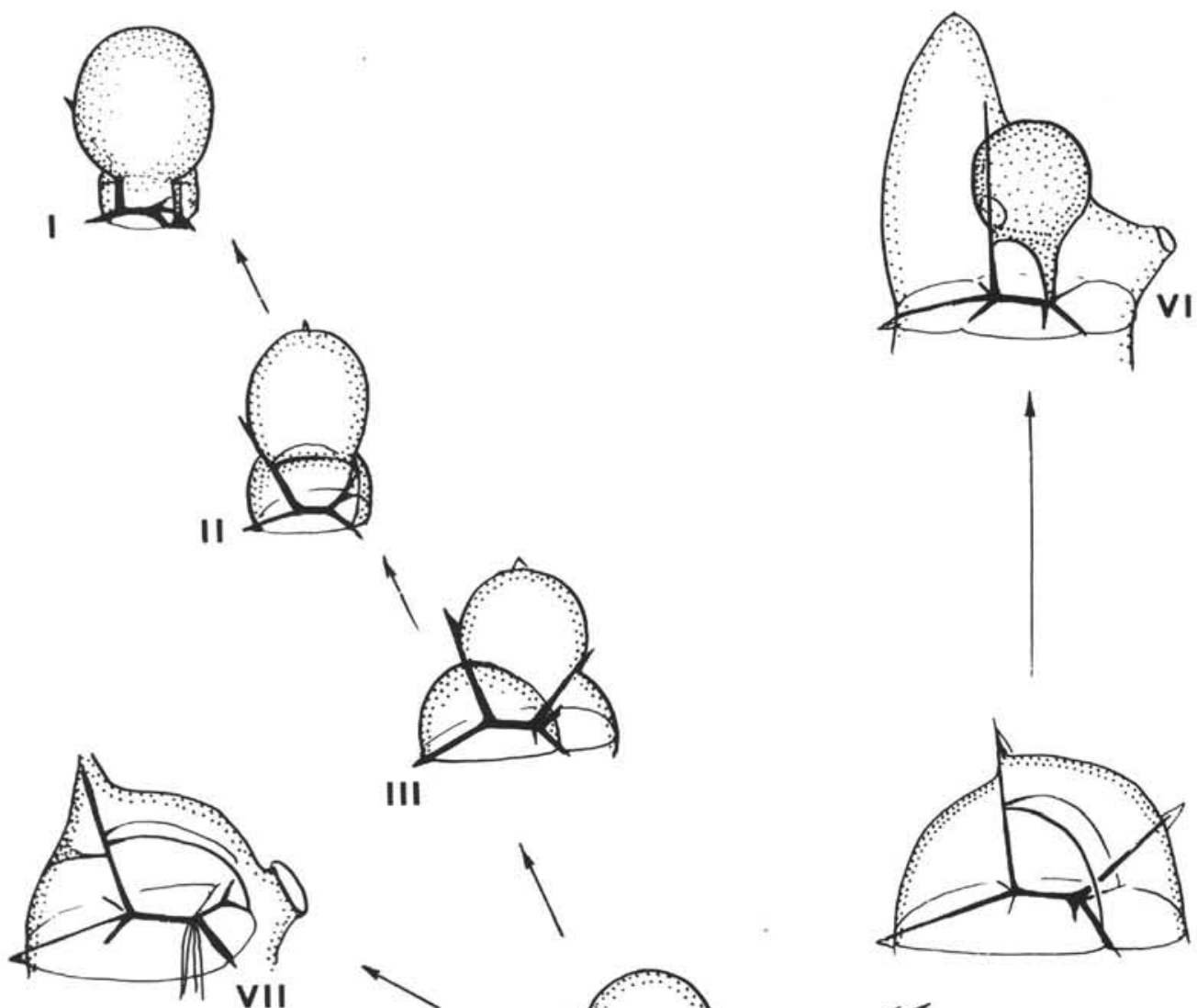

III
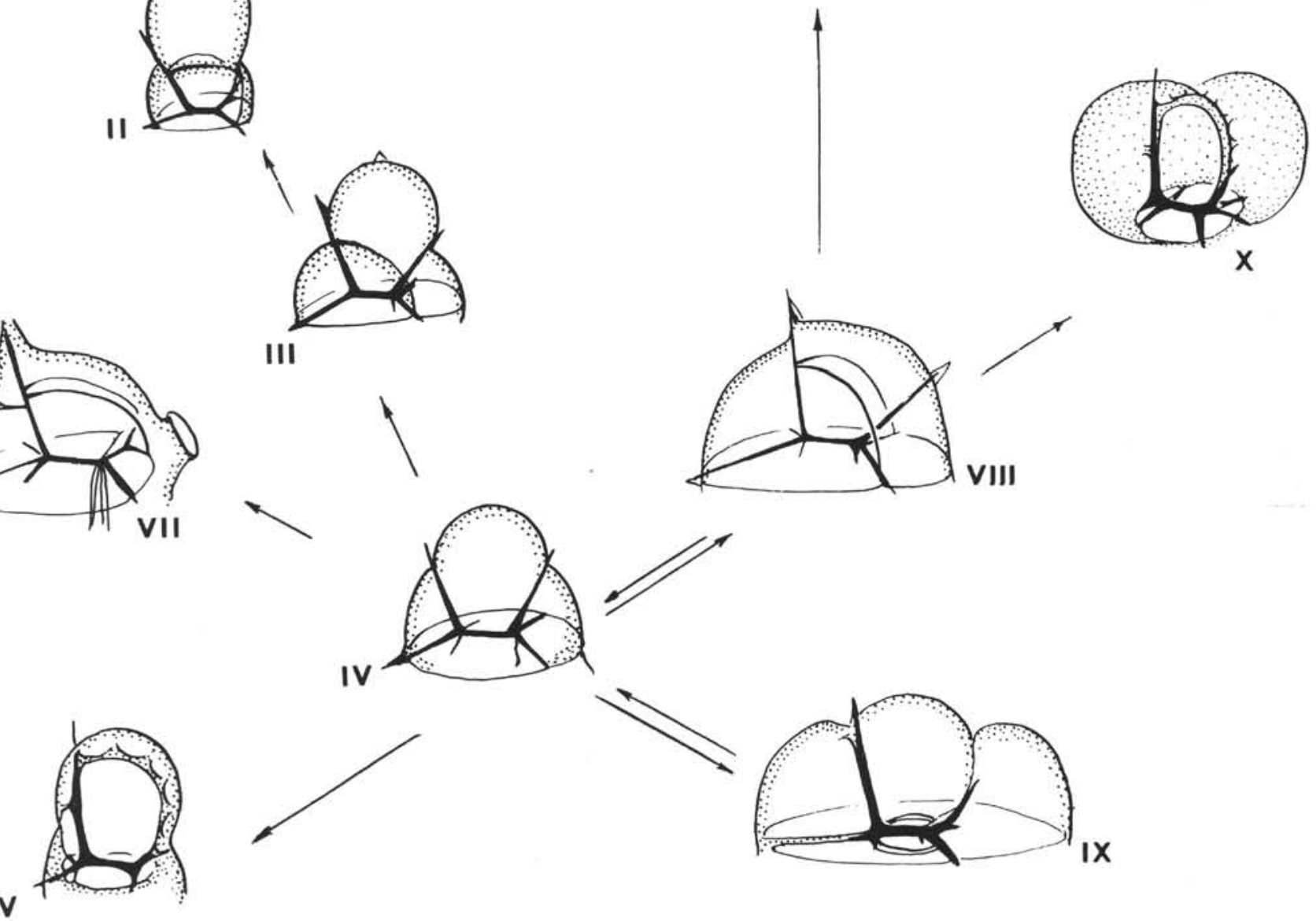

Figure 10. Types of the cephalis. 


\section{Artostrobus (?) pretabulatus n. sp.}

(Plate 10, Figures 2, 3)

Lithocampana sp. S. Petrushevskaya, ?1973, pl. 3, fig. 23.

Skeleton cylindrical, two segments. Cephalis rather typical for Theocampidae, nearly the same as in Artostrobus sp. Cr. and A. pusillum. The second segment has the same outline as these two species but the pores are arranged in longitudinal (not transverse) rows; about five longitudinal rows on a half of the equator. This feature is quite untypical for $A$. annulatus, but in some specimens of Artostrobus sp. Cr. longitudinal rows can be seen. The arrangement of the pores and their size in A. pretabulatus are nearly the same as in Sethoconus tabulatus (Ehrenberg) (see Petrushevskaya, ?1967, pl. 54, fig. 1-8). In Sethoconus (?) tabulatus the skeleton is shorter, has thinner walls, and the number of the longitudinal rows of pores is a bit larger than in A. pretabulatus.

Oligocene-Miocene.

The description is based on 14 specimens from Site 278 (Sample 31$3,40 \mathrm{~cm}$; Core 27, Section 3, and Core 26, Section 4) plus some additional cores. Holotype No. 62246.

Subfamily THEOCORINAE Haeckel, emend.

Triocyrtida Haeckel, 1881, p. 434; 1887, p. 1396.

Theocorida Haeckel, 1881, p. 434, part; 1887, p. 1396.

Calocyclida Haeckel, 1881, p. 434, part.

Subfamily group E in Petrushevskaya and Kozlova, 1972, p. 542.

Small cephalis (of the type shown on Figure 10, IV) with high arranged branches, and without well-developed additional lobes. Cephalis is conical, its apex gradually turns into apical horn. The largest skeleton segment is the abdomen. As a rule, abdominal pores are much larger than thoracic pores, walls of the thorax and abdomen differ. Pores are arranged in checkerboard order; longitudinal rows are seen.

Paleogene.

\section{Genus CALOCYCLAS Ehrenberg}

Calocyclas Ehrenberg, 1847b, p. 54; Haeckel, 1887, p. 1381; Campbell, 1954, p. 132; Petrushevskaya and Kozlova, 1972, p. 547.=Calocycliss $a$ Haeckel, 1887, p. 1383; Campbell, 1954, p. 132. Type species Calocyclas turris Ehrenberg, 1875, pl. 18, fig. 7 .

Genus rather untypical for the subfamily, because thorax may be of the same size, or even smaller than the abdomen, and the pores on the abdomen may be of the same size as those on the thorax. However, the walls of the abdomen, and thorax differ in thickness. Thorax has a rather stable size and shape (the globe is approximately $80 \mu-100 \mu$ in diameter). Calocycletta may be closely related to Calocyclas.

\section{Calocyclas (?) semipolita Clark and Campbell group}

(Plate 8, Figure 8; Plate 41, Figures 6, 7)

Calocyclas semipolita semipolita Clark and Campbell, 1942, p. 83, pl. 8 , fig. $12,14,17-19,22,23$; 1945, p. 44 , pl. 6 , fig. $14,16,17$.

\section{Calocyclas (?) fragilis (Carnevale) group}

(Plate 8, Figures 6, 7)

(?)Theopera fragilis Carnevale, 1908, pl. 4, fig. 22.

(?)Theopera aculeata Carnevale, 1908, pl. 4, fig. 23.

Very much the same as $C$. (?) semipolita type, but variable abdomen shape and pore arrangement. Rings and ribs are common in the abdomen walls. All these characteristics are quite untypical for Calocyclas.

Calocyclas (?) sp. K (Plate 21, Figure 10)

Abdomen is very short, usually broken. Very similar to Clathrocorona species, but smaller. Very similar to Lychnocanium sp. C, but without feet.

In the Antarctic, latest Miocene.

\section{Genus THEOCOTYLE Riedel and Sanfilippo}

Theocotyle Riedel and Sanfilippo, 1970, p. 524; Petrushevskaya and Kozlova, 1972, p. 543; Foreman, 1973, p. 440. Type species Theocotyle venezuelensis Riedel and Sanfilippo, 1970, pl. 6, fig. 10. Cephalis middle-size, conical, without "neck" (Figure 10, IV). The thorax is conical, similar to that of Stichocorys, but larger. The ab- domen is cylindrical or ellipsoidal with large pores arranged in longitudinal rows. Thorax and abdomen are separated by the inner ring.

\section{Theocotyle robusta (Clark and Campbell)}

(Plate 8, Figure 9; Plate 22, Figure 1)

(?)Calocyclas semipolita robusta Clark and Campbell, 1942, p. 84, pl. 8, fig. 21.

The abdomen is shorter than in typical C. semipolita, and less regular both in its shape, mouth, and pores. Also the thorax has a different outline than typical $C$. semipolita.

Oligocene.

Remarks: Th. robusta from Antarctic deposits looks similar in all features to some specimens of Th. cryptocephala (?) nigrinae (Foreman, 1973, pl. 4, fig. 5).

\section{Genus THYRSOCYRTIS Ehrenberg}

Thyrsocyrtis Ehrenberg, 1847b, p. 54; Haeckel, p. 1350; Campbell, 1954, p. 130; Riedel and Sanfilippo, 1970, p. 525; Petrushevskaya and Kozlova, 1972, p. 542. Type species Thyrsocyrtis rhizodon Ehrenberg, 1873, p. 1875 , pl. 12, fig. 1 .

The genus is quite characteristic for the subfamily and at the same time not as specialized as (having more evolutional potence) Lampterium.

\section{Thyrsocyrtis sp. \\ (Plate 8, Figure 10)}

(?)Podocyrtis strangulata Vinassa de Regny, 1900, pl. 2, fig. 39.

(?)Cyclampterium (?) milowi Riedel and Sanfilippo, 1971, p. 1593, pl. 7, fig. 8-9.

The abdomen is narrower than in typical C. milowi, and the terminal feet do not have special small pores. In $P$. strangulata, the abdomen is also much broader than in this species. Podocyrtis chalara differs from the Thyrsocyrtis sp. not only by the larger pores of the abdomen, but also by the conical cephalis.

\section{Genus THEOCORYS Haecke}

Theocorys Haeckel, 1881 , p. 434 ; 1887, p. 1414 ; non Campbell, 1954 , p. 134, but Strelkov, Khabakov, and Lipman, 1959, p. 457; Riedel, 1959 b, p. $26 .=$ Theocoronium Haeckel, 1887, p. 1415. Type species Theocorys veneris Haeckel, 1887, pl. 69, fig. 15.

Cephalis small and the theoperid is a "crypto-type" (Figure 10, IV). The thorax is cupola shaped with the abdomen as an irregular cylinder the same length as or longer than the thorax. The walls of the thorax and the abdomen are the same thickness, with some pores. The difference from Calocyclas is in the smaller shell dimensions, the thinner walls, and smaller pores.

\section{Theocorys longithorax n. sp.}

(Plate 8, Figures 17, 18; Plate 22, Figure 2)

The length and width of the thorax and the width of the abdomen is about $50 \mu$. The length of the abdomen is variable; the mouth constricted. The cephalis is "simple theoperid". About 10-12 longitudinal rows of the pores on a half of the equator. The outline of the shell, and especially the conical shape of the thorax are very much the same as in Theocotyle robusta (Plate 8, Figure 9). It is possible that this species and the species referred to as Theocotyle robusta belong to the same genus. Differs from Theocorys cretica (Ehr.) (Plate 8, Figure 14) in having a more elongated shell. In this characteristic the shell is similar to Theocorythium cranoides (see Petrushevskaya, ?1971a, pl. 118, fig. 5, $6)$, but the cephalis is different.

Antarctic Oligocene.

Holotype No. 62247. Description is based on specimens from Site 278 (Core 20).

\section{Subfamily EUCYRTIDIINAE Ehrenberg}

Cephalis (Figure 10, IV or V) small compared with the whole skeleton; shell multisegmented as a rule. Pores can be seen in checkerboard order or longitudinal rows. No strong feet. Cephalothorax usually conical or pyramidal but not always stable in different genera; it may be of various outline and size. However, the thorax is not less than 2-3 times bigger than the cephalis in all representatives of the subfamily. 


\section{Genus STICHOPODIUM Haeckel}

Stichopodium Haeckel, 1881, p. 439; 1887, p. 1447; Campbell, 1954, p. 136; Petrushevskaya and Kozlova, 1972, p. 548. Type species Stichopodium dictyopodium Haeckel, 1887, pl. 75, fig. 6 .

The postthoracic part of the shell seems to be secondarily segmented and the genus very probably originated from three-segmented forms or from undescribed Eusyringium species (Plate 8, Figures 16, 22). The most ancient species of that lineage is Phormocyrtis turgida (Krasheninnikov) group (Foreman, 1973, pl. 7, fig. 10). Stichocorys saccoi Vinassa de Regny (1900, pl. 3, fig. 7) referred in Petrushevskaya and Kozlova, (1972, pl. 26, fig. 9, 10, 20) as Stichopodium martellii (Principi) typ. and as $S$. martellii conicum. The species of Eucyrtidium cienkowskii Haeckel group and $E$. calvertense Martin group are closely related to $S$. saccoi Vinassa de Regny.

\section{Stichopodium inflatum (Kling) group}

$$
\text { (Plate 26, Figures 7, 8) }
$$

(?)Eucyrtidium lagena Haeckel, 1862, pl. 4, fig. 11.

(?)Eucyrtidium matuyamai Hays, 1970, p. 213, pl. 1, fig. 7-9; Kling, 1971, p. 1088, pl. 1, fig. 4 ; 1973, p. 636, pl. 4, fig. 17.

Stichopodium sp. aff. Eucyrtidium matuyamai Hays in Petrushevskaya and Kozlova, 1972, p. 549, pl. 26, fig. 5, 6, 15, 16.

Eucyrtidium inflatum Kling, 1973, p. 636, pl. 11, fig. 7, 8, pl. 15, fig. $7-$ 10.

The skeleton is widest at the third segment, the same as in $S$. saccoi, but the number of the pores is less. $S$. inflatum is smaller (shorter) than $E$, lagena and $E$. matuyama. The relation of the species of Stichopodium (biconica, saccoi, matuyamai, cienknowskii, etc.) remains rather obscure.

\section{Stichopodium calvertense (Martin) group} (Plate 14, Figure 29)

Eucyrtidium calvertense Martin, 1904, p. 450, pl. 130, fig. 5.

Stichopodium calvertense (Martin) Petrushevskaya and Kozlova, 1972, p. 549 , pl. 26 , fig. 13.

The broadest part of the shell is the second or third of the postthoracic segments. The first of the postthoracic segments is no longer than the others.

Miocene.

\section{Stichopodium saccoi (Vinassa de Regny) group} (Plate 14, Figure 30)

Stichocorys saccoi Vinassa de Regny, 1900, pl. 3, fig. 17.

Stichocorys martellii Principi, 1909, p. 16, pl. 1, fig. 52.

Stichocorys aemiliana Principi, 1909, p. 17, pl. 1, fig. 53.

Stichopodium martellii (Principi) Petrushevskaya and Kozlova, 1972, pl. 26, fig. 9, 10; Petrushevskaya, ?1973, pl. 3, fig. 18.

Stichopodium martellii conicum Petrushevskaya and Kozlova, 1972, p. 548 , pl. 26 , fig. 20 .

The ring between the third and the fourth segment is arranged on the narrower part of the shell. The third segment is broadest and longest.

Miocene.

Stichopodium biconicum (Vinassa de Regny) group (Plate 14, Figures 25-27; Plate 22, Figure 7)

Lithocampe biconica Vinassa de Regny, 1900, pl. 3, fig. 30. (?)Spyrocyrtis elegans Nakaseko, 1963, p. 196, pl. 3, fig. 13, 14. Eucyrtidium calvertense robusta Petrushevskaya, ?1973, p. 23, pl. 3, fig. 16.

The first postthoracic segment is the longest and is nearly as broad as the broadest part of the shell.

Miocene-Pliocene in temperate and cold-water regions.

\section{Genus EUCYRTIDIUM Ehrenberg}

Eucyrtidium Ehrenberg, 1847a, p. 54; Haeckel, 1887, p. 1487; Nigrini, 1967, p. 81, part; Campbell, 1954, p. 140; Petrushevskaya, 1971b, p. 215, part; Petrushevskaya and Kozlova, 1972, p. 548.=Eucyrtis Haeckel, 1887, p. $438 ; 1887$, p. 1488. Type species Lithocampe acuminata Ehrenberg, 1844; 1854, pl. 22, fig. 27.

Very similar to Stichopodium, but might originate from multisegmented forms like Eucyrtidium (?) montiparum Ehr. (Petrushevskaya and Kozlova, 1972, pl. 26, fig. 2-4). However, the latter seems to be related with Eucyrtidium cubense Sanfilippo and Riedel (Foreman, 1973, pl. 7, fig. 11), and thus Stichopodium and Eucyrtidium may have descended from different ancestors.

\section{Eucyrtidium acuminatum (Ehrenberg) group (Plate 14, Figure 28)}

Lithocampe acuminata Ehrenberg, ?1844, p. 84. Eucyrtidium acuminatum (Ehrenberg) Ehrenberg 1854, pl. 22, fig. 27; Stöhr, 1880, p. 104, pl. 4, fig. 6; Petrushevskaya, 1971b, p. 217; Petrushevskaya and Kozlova, 1972, p. 548, pl. 26, fig. 17.

The skeleton outline is almost without an external constriction.

Very rare in Antarctic and subantarctic Tertiary sediments.

Eucyrtidium sp. M

(Plate 14, Figure 20)

Distinguished from E. acuminatum by deep constrictions between segments. The entire skeleton is longer. It is somewhat similar to Eucyrtidium montiparum (Petrushevskaya and Kozlova, 1972, pl. 26, fig. 2-4).

Eucyrtidium sp. A

(Plate 14, Figures 21, 22)

Similar to Eucyrtidium sp. M, but the rings between the segments are irregular (curved, nearly spiral). The stout, long apical horn is characteristic.

Late Miocene-Pliocene in subantarctic.

\section{Genus ARTOCYRTIS Haeckel}

Artocyrtis Haeckel, 1887, p. 1490; Campbell, 1954, p. 140; Petrushevskaya and Kozlova, 1972, p. 549. Type species Eucyrtidium profundissimum Ehrenberg, 1872, pl. 7, fig. 12.

Thorax greater than in Eucyrtidium species in dimensions and compared to the postthoracic part of the shell.

\section{Artocyrtis punctatus (Ehrenberg) group}

Eucyrtidium puntatum Ehrenberg, 1854, pl. 22, fig. 24.

Artostrubus zitteli Vinassa de Regny, 1900, pl. 3, fig. 19.

Artostrobus elongatus Vinassa de Regny, 1900, pl. 3, fig. 20.

(?)Theocyrtis hirta Vinassa de Regny, 1900, pl. 3, fig. 1.

Theocyrtis globosa Vinassa de Regny 1900, pl. 3, fig. 2.

Artocyrtis sp. Petrushevskaya and Kozlova, 1972, pl. 26, fig. 11.

Eucyrtidium punctatum Ehr. Sanfilippo et al., ?in press, pl. 5, fig. 15, 16.

Antarctic specimens from Site 278 (Cores 19, 20) are very much the same as European as illustrated by Sanfilippo.

"Form E" occurs at Site 281, distinguished by a very long thorax. It is the broadest part of the skeleton. The third segment is small and short.

\section{Genus LITHOCAMPE Ehrenberg}

Lithocampe Ehrenberg, 1838, p. 128; Haeckel, 1887, p. 1501; Campbell, 1954, p. 140; Petrushevskaya and Kozlova, 1972, p. 546.=Lithocampula Haeckel, 1887, p. 1502. Type species Lithocampe radicula Ehrenberg, 1838; 1854, pl. 22, fig. 23a.

Eusyringoma Haeckel, 1887, p. 1498; Frezzell and Middour, 1951, p. 35; Campbell, 1954, p. 140. Type species Eucyrtidium lagenoides Stöhr, 1880. pl. 4, fig. 8.

\section{Subgenus LITHOCAMPE Ehrenberg}

Lithocampe (Lithocampe) subligata Stöhr group (Plate 14, Figures 6-9, 12)

Lithocampe subligata Stöhr, 1880. p. 102, pl. 4, fig. 1; Petrushevskaya and Kozlova, 1972, p. 546, pl. 25, fig. 7-10; Petrushevskaya, ?1973, pl. 3 , fig. 4 .

(?)Lithocampe eminens Stöhr, 1880, p. 102, pl. 4, fig. 4.

(?)Lithocampe fimbriata Stöhr, 1880, p. 103, pl. 4, fig. 3.

(?)Eucyrtidium elongatum Stöhr, 1880, p. 105, pl. 4, fig. 10.

(?)Eucyrtidium acutatum Stöhr, 1880, p. 106, pl. 4, fig. 11 . 
(?)Eucyrtidium raphanus Stöhr, 1880, p. 106, pl. 4, fig. 12.

(?)Eucyrtidium infraaculeatum Stöhr, 1880, p. 106, pl. 4, fig. 13.

Rather variable Oligocene-Miocene species.

\section{Lithocampe punctata (Stöhr)}

(Plate 14, Figures 10, 13)

Dictyomitra punctata Stöhr, 1880, p. 101, pl. 3, fig. 24; Petrushevskaya ?1973, pl. 3, fig. 2, 3.

Slender skeleton if compared with L. subligata. Non Eucyrtidium punctatum (Ehrenberg) in Sanfilippo et al., in press (pl. 5, fig. 15, 16).

\section{Subgenus CYRTOCAPSELLA Haeckel}

Eusyringoma Haeckel, 1887, p. 1498; Frezzel and Middour, 1951, p. 35; Campbell, 1954, p. 140.

Eucyrtidium lagenoides Stöhr, 1880, pl. 4, fig. 8.

Cyrtocapsella Haeckel, 1887, p. 1512; Campbell, 1954, p. 143; Sanfilippo and Riedel, 1970, p. 451; Riedel and Sanfilippo, 1970, p. 530; Petrushevskaya and Kozlova, 1972, p. 546. Type species Cyrtocapsa tetrapera Haeckel, 1887, pl. 78, fig. 5.

Syringium Principi, 1909; Campbell, 1954, p. 142; Riedel and Sanfilippo, 1970, p. 530. Type species Syringium vinassai Principi, 1909, pl. 1, fig. 60 .

Three to five segments.

\section{Lithocampe (Cyrtocapsella) cylindroides Principi} (Plate 14, Figures 14, 15)

(?)Lithocampe radicula Ehrenberg, 1854, pl. 22, fig. 23a.

Stichocapsa cylindroides Principi, 1909, p. 20, pl. 1, fig. 66; Petrushevskaya, ?1973, pl. 3, fig. 5.

Lithocampe sp. Petrushevskaya and Kozlova, 1972, pl. 25, fig. 13.

Five segments. The fourth segment is narrower than the third. Differs from Stichocorys species by the second segment being less distinguished from the other segments.

Miocene.

\section{Lithocampe (Cyrtocapsella) tetrapera (Haeckel)}

Cyrtocapsa tetrapera Haeckel, 1887, p. 1512, pl. 78, fig. 5.

Cyrtocapsella tetrapera (Haeckel) Riedel and Sanfilippo, 1970, p. 530, pl. 14, fig. 7.

Lithocampe tetrapera (Haeckel), Petrushevskaya and Kozlova, 1972, p. 546, pl. 25 , fig. 14.

Miocene.

\section{Lithocampe (Cyrtocapsella) compacta (Haeckel)}

Cyrtocapsa compacta Haeckel, 1887, p. 1512, pl. 77, fig. 8; Petrushevskaya and Kozlova, 1972, p. 546, pl. 25, fig. 17; Petrushevskaya ?1973, pl. 3, fig. 8.

Cyrtocapsa inaquispina Principi, 1909, p. 19, pl. 1, fig. 62.

(?)Cyrtocapsa subconica Nakaseko, 1963, p. 120, pl. 4, fig. 9.

The second and fourth segments are nearly equal in size to the third.

\section{Lithocampe (Cyrtocapsella) compressa Stöhr}

(Plate 14, Figure 23)

Lithocampe compressa Stöhr, 1880, p. 103, pl. 4, fig. 5 .

(?)Theocapsa himmiensis Nakaseko, 1963, p. 184, pl. 3, fig. 1-3; 1970, pl. 2, fig. 4.

Rather similar to Dicolocapsa elongata Vinassa de Regny 1900 (pl.

2, fig. 36) in Sanfilippo et al., ?in press, pl. 5, fig. 3).

Miocene.

\section{Lithocampe (Cyrtocapsella) cornuta Haeckel}

Cyrtocapsa cornuta Haeckel, 1887, pl. 78, fig. 9.

Cyrtocapsella cormuta (Hck.) Riedel and Sanfilippo, 1970, pl. 14, fig. 8.

Lithocampe cornuta (Haeckel) Petrushevskaya and Kozlova, 1972, p. 546 , pl. 25 , fig. $15,16$.

Atypical at Site 281 , rather similar to the specimen from Europe

(Sanfilippo et al., ?in press) pl. 5, fig. 1, 2).

\section{Lithocampe (Cyrtocapsella) japonica (Nakaseko)}

(Plate 14, Figures 17, 18)

Eusyringium japonicum Nakaseko, 1963, p. 193, pl. 4, fig. 1-3, fig. 20, 21; Petrushevskaya ?1973, pl. 3, fig. 7.
(?)Theocapsa elongata Nakaseko, 1963, p. 185, pl. 3, fig. 4, 5 .

Cyrtocapsella tetrapera Haeckel sensu Bandy, Casey, and Wright, 1971, pl. 2, fig. 1.

Rather variable species. The fourth segment is in a process of reduction. Form "A" with small third segment, Form "B" with bigger third segment.

Miocene.

\section{Genus STICHOCORYS Haeckel}

Stichocorys Haeckel, 1881, p. 438; 1887, p. 1479; Campbell, 1954, p. 140; Sanfilippo and Riedel, 1970, p. 530; Petrushevskaya and Kozlova, 1972, p. 546. Type species Stichocorys wolfii Haeckel, 1887 , pl. 80 , fig. 10.

(?)Cyrtocapsa Haeckel, 1881, p. 439; 1887, p. 1512; non Campbell, 1954, p. 143; but Riedel, 1959b, p. 11. Type species Cyrtocapsa chrysalidium Haeckel, 1887, pl. 76, fig. 9.

\section{Stichocorys delmontensis (Campbell and Clark)}

Miocene, in the subantarctic also.

\section{Stichocorys peregrinas (Riedel) \\ (Plate 14, Figure 16)}

Late Miocene-Pliocene, in the subantarctic also. Some specimens are similar to Lithocampe (Cyrtocapsella) cylindroides Principi. S. peregrinas may be related to $L$. cylindroides.

\section{Lithopera renzae Sanfilippo and Riedel}

Lithopera renzae Sanfilippo and Riedel, 1970, p. 454, pl. 1, fig. 24-26, 28; Kling, 1973, pl. 11, fig. 25.

Middle Miocene.

\section{Subfamily LITHOSTROBIIDAE $\mathrm{n}$. subfam.}

Multisegmented skeleton. Cephalis is very small if compared to the whole shell. Cephalis simple (Figure 10, IV, V, rare of the type III). The thorax is 1.1-2.5 times larger than the cephalis. The third segment is only a little larger than the second, etc. Pores in transverse rows are found in the genera Lithostrobus Butschli, 1862,=Cyrtostrobus Haeckel, 1887. Eucyrtidium argus Ehrenberg), Cyrtolagena Haeckel, 1879 (Cyrtolagena laguncula Haeckel, ?1879); Sticholagena Haeckel (Stichopera pectinata, Haeckel, 1887) Amphipternis Foreman, 1973 (Lithocampe clava Ehrenberg, 1873) (Plate 14, Figures 1-4). In the Mesozoic these genera with the very small thorax were most closely related to the species of Stichocapsa Haeckel, 1881 (S. jaspidea Rust, 1885 ) with the larger (like in Lithocampe) thorax. Stichocapsa (Stichomitra sensu Foreman, 1968) species have transverse rows of pores, the same as Lithostrobids.

These Lithostrobids cannot be placed (or united with) in Amphipyndacidae, because in Amphipyndacidae the cephalis is subdivided into an upper part and "neck". The two parts are of nearly equal size. In Lithostrobiinae the two uppermost parts of the skeleton are cephalis and thorax. These two segments may look very much like little dicyrd (Petrushevskaya, 1971b, pl. 88, 89), settled on the strobila. The branches $a$ may go from the middle of the spine $A$ and form the pronounced arches $a p$ in the walls of the cephalis which is characteristic for the Dicyrtids. Although type species Amphipternis Foreman is a very distinguishing species, the features (as Foreman emphasized in the diagnosis) are common in Cyrtolaegna as well as in Dicyrtids.

The Paleocene species (Plate 14, Figures 1,2) are very similar to Lithocampe (?) clava Ehrenberg sensu Foreman, 1973 in having unpronounced branches $a$ (characteristic for the genus Amphipternis Foreman). This is why the species in question is referred to as Lithostrobus (?) clava. It is possible that this feature is variable in Lithostrobids, and if so, the diagnosis of Amphipternis must be amended, and its relation to Lithostrobus, Cyrtolagena, and Stichocapsa established.

\section{Genus CYRTOLAGENA Haeckel}

Cyrtolagena Haeckel, 1879; Atlas, 1887, p. 1451; Campbell, 1954, p. 138; Petrushevskaya, 1971b, p. 171. Type species Cyrtolagena laguncula Haeckel, 1879; 1887, pl. 75, fig. 10.

Sticholaegna Haeckel, 1887, p. 1449; Campbell, 1954, p. 136.

Stichopera pectinata $\mathrm{Haeckel,} \mathrm{1887,} \mathrm{pl.} \mathrm{75,} \mathrm{fig.} 11$. 


\section{Cyrtolagena laguncula Haeckel}

(Plate 14, Figures 3, 4)

Cyrtolagena laguncula Haeckel, 1879, pl. 75; Petrushevskaya, 1971b, p. 173, pl. 89 , fig. $1-3$.

Cyrtopera laguncula Haeckel, 1887, pl. 75, fig. 10; Casey, 1971, pl. 1, fig. 10.

Miocene-Recent.

\section{Family LYCHNOCANIIDAE Haeckel}

Lychnocaniidae Haeckel, 1881, p. 432; Petrushevskaya, 1971b, p. 227; Petrushevskaya and Kozlova, 1972, p. 552 (part).

Diagnosis: Eucyrtidioidea with the cephalis up to $40 \mu-45 \mu$ in height. It may be a small "theoperid" (Figure 10, IV) with rudimental branches and arches. The skeleton is (as a rule) three-segmented, sometimes consisting of the cephalis, thorax, and abdomen, but often the (Lithochytris) thorax, and abdomen are confused in the second segment. In this case the third segment (if present) doesn't represent a real abdomen (Petrushevskaya and Kozlova, 1972, pl. 27, fig. 2). The second segment (thorax or thorax-abdomen) is the biggest.

Strong external spines $D$ and $L$ are seen in most genera. The pores are arranged in more or less regular checkerboard order, and usually longitudinal rows may be seen.

Cenozoic. It seems likely that the family rose from a number of Mesozoic eucyrtidioid genera (not from the same genus).

The family differs from the other eucyrtids by the stabilization and peculiarity of the whole skeleton shape-the skeleton became tripoid, and by the cephalis never being of the pterocoryid, carpocanoid, or artostrobid type. The family Lychnocaniidae have some genera similar to (parallel or convergent with) the sethoperid and pterocoryid genera Pteropilium, Lipmanella, etc., but in Sethoperidae the pores are arranged in the transverse rows. The sethoperids also possess the tendency to develop latticed plates. The difference from Pterocoryinae is less, mainly in the skeleton shape and tripod. In the development of the "pedestal" of the cephalis, the Lychnocaniidae are similar to Neosciadiocapsidae and to Artostrobium.

\section{Genus LYCHNOCANIUM Ehrenberg}

Lychnocanium Ehrenberg, 1847b, p. 54; Haeckel, 1881, p. 432; 1887, p. 1224; Campbell, 1954, p. 124; Riedel and Sanfilippo, 1970, p. 529; Petrushevskaya and Kozlova, 1972, p. 553.=Lychnocanissa Haeckel, 1887, p. 1226; Campbell, 1954, p. 124. Type species Lychnocanium falciferum Ehrenberg (1854, pl. 36, fig. 7).

Fenestracantha Bertolini, ?1935.

The cephalis is small or medium size (up to $30 \mu$ ) similar to the construction shown on Figure 10, IV or V. Sometimes it has a pedestal Thorax or cupola is globe-shaped if there is no pedestal. The definite inner ring is between the thorax and the abdomen. As a rule the abdomen is very delicate or undeveloped (or unpreserved?). The pores of the thorax and abdomen are of different shapes and size. Three feet going from the thorax.

\section{Lychnocanium grande Campbell and Clark group}

Lychnocanium grande Campbell and Clark, 1944a, p. 42, pl. 6, fig. 3-6; Petrushevskaya and Kozlova, 1972, p. 553, pl. 29, fig. 6.

Eight or nine pores on the thorax between two feet. Feet are threeedged, divergent, not parallel, and nearly straight. No pedestal.

Remarks: In Antarctic Miocene specimens of the same size occur, but with curved feet and fewer pores (Plate 12, Figure 7).

\section{Lychnocanium sp. C}

(Plate 12, Figure 16)

Feet go from the margin of the thorax. They are directed downward, are parallel, and very weak. Thorax is no smaller than in $L$. grande, but with fewer pores.

Latest Miocene in Antarctic.

\section{Genus LYCHNOCANELLA Haeckel}

Lychnocanella Haeckel, 1887, p. 1224; Campbell, 1954, p. 124. Type species Lychnocanium lanterna Haeckel, 1887, pl. 61, fig. 7.

Lithochytrodes Haeckel, sensu Petrushevskaya and Kozlova, 1972, p. 552 , part.

Lychnocanomma Haeckel, sensu Foreman, 1973, p. 436, part.
Differs from Lychnocanium and $L$. clavigerum Haeckel (the type species of Lychnocanomma Hck.) by the pear-shaped outline of the second segment. The feet are solid. The third segment (abdomen?) may be present. It is possible that the second segment is composed only of the thorax (possibly with the "pedestal" of the cephalis). It is also possible that the second segment may be composed of the thorax plus abdomen. The species Lithochytris tripodium Ehr. =Dictyophimus babylonis Clark and Campbell group seems to belong in the genus Lychnocanella. Some of the species of this group were referred by Foreman (1973, pl. 2, fig. 1, 5,6) as Lychnocanomma Haeckel, but they cannot be related to $L$. clavigerum. The species with the same outline but much larger and with the enormous second segment are better placed in Lithochytrodes Haeckel (Petrushevskaya and Kozlova, 1972, p. 552, pl. 27). Some of them were referred as Lamptonium (Foreman, 1973, pl. 6, fig. 1-5).

\section{Lychnocanella conica (Clark and Campbell)}

(Plate 12, Figures 2, 11-15)

Lychnocanium conicum Clark and Campbell, 1942, p. 71, pl. 9, fig. 38.

Antarctic Oligocene specimens forma typica (Plate 12, Figures 1214) are larger, have a thicker skeleton, and more pores (8-10 between two feet) than smaller Miocene specimens (Plate 12, Figure 11), which have only 6-7 pores. The feet are weak. The Miocene specimens ("small-forma") are very similar to the type species of the genus Lychnocanium lanterna, and to the Oligocene specimen, illustrated by Petrushevskaya and Kozlova, 1972, pl. 27, fig. 12. The other Antarctic Miocene specimens (Plate 12, Figure 2) have longer feet and more pores. They are very similar to $L$. grande, but the thoracic pores are a bit larger, and the feet may be curved. Their pedestal is similar to that in typical Bekoma (Plate 12, Figure 3). In that respect these specimens are similar to Orbula comitata Foreman (1973, pl. 10, fig. 7), but in the Antarctic specimens the feet are longer, and the pores smaller and more numerous.

The most ancient Antarctic specimens (Plate 12, Figures 12, 15) look similar to the species group of Pterocanium pyramis Haeckel and Theopodium satelles Kozlova (Plate 12, Figure 10) characteristic for the tropical Paleocene.

\section{Genus DICTYOPHIMUS Ehrenberg}

Dictyophimus Ehrenberg, 1847, p. 53; Haeckel, 1881, p. 432; 1887, p. 1195; non Campbell, 1954, p. 122; but Nigrini, 1967, p. 66; Petrushevskaya and Kozlova, 1972, p. 553.=Dictyophimium Haeckel, 1887, p. 1195. Type species Dictyophimus crisae Ehrenberg, 1854 , p. $241 .=(?)$ D. arabicus Ehrenberg, ?1872, pl. 10, fig. 3 .

\section{Dictyophimus hirundo (Haeckel) group}

Pterocorys hirundo Haeckel, 1887, p. 1318, pl. 71, fig. 4; Riedel, 1958, p. 238 , pl. 3, fig. 11; Petrushevskaya, 1967, p. 115 , pl. 67 , fig. 1-5. Dictyophimus hirundo (Hck.) group, Petrushevskaya, 1971b, pl. 111, fig. 4, 5; ?1973, pl. 3, fig. 31; Petrushevskaya and Kozlova 1972, p. 553 , pl. 27 , fig. 16,17 .

The pores are arranged in irregular longitudinal rows. The first specimens of the species appeared in the Antarctic Miocene and are similar to Gondwanaria dogeli in having the same cephalis, spines $D$ and $L$ somewhat longer than in the typical $G$. dogeli and directed slightly downward, the narrower shell up to the mouth, the same shell walls and pores; and indistinct subdivision into thorax and abdomen.

Many species $D$. hirundo itself, $D$. triserratus Hck., D. crisae Ehr., $D$. arabicus (Ehr.), and D. splendens (Campbell and Clark) (Plate 25, Figures $3,4,8$ ) have a nearly similar shell construction but it is important to notice if they have differences in their feet and horns and if in some cases these apophyses are hollow.

Miocene-Recent.

\section{Dictyophimus (?) archipilium n. sp.}

$$
\text { (Plate 25, Figures 1, 2) }
$$

Differs from $D$. hirundo by the smaller cephalic, thoracic, and abdominal dimensions. The main shell construction is the same. Only the apical horn is weak, but that characteristic is also known for some races of D. hirundo (Petrushevskaya and Kozlova, 1972). The pores in D. archipilium are arranged in transverse rows similar to Archipilium species. Holotype No. 62248 in the collection of Marine 
Hydrobiology. The description is based on specimens from Site 278 . Named after the genus Archipilium.

\section{Genus ARCHIPILIUM Haeckel}

Archipilium Haeckel, 1881, p. 427; 1887, p. 1139; Campbell, 1954, p. 117; Petrushevskaya and Kozlova, 1972, p. 553. Type species Archipilium orthopterum Haeckel, 1887, pl. 98, fig. 7.

(?)Nothotripodiscinus Deflandre, 1972, p. 229. Type species Nothotripodiscimus johannismonicae Deflandre, 1972, fig. 1-3.

The feet, formed by the spines $D$ and $L$ are very similar in arrangement and shape to those of Dictyophimus. The feet can be considered hollow, but in reality they have a channel (Plate 43, Figure 5). No external apical horn. Sometimes a small tube, is connected with the spine Vert. Cephalis is without a "neck", no thorax and abdomen subdivision, and pores in transverse rows.

\section{Archipilium sp. aff. A. macropus (Haeckel) group} (Plate 12, Figure 9; Plate 43, Figures 3-5)

(?) Sethopilium macropus Haeckel, 1887, p. 1203, pl. 97, fig. 9; Petrushevskaya and Kozlova, 1972, pl. 29, fig. 13, 14; Petrushevskaya ?1973, pl. 3, fig. 28.

Some Miocene specimens of Site 278 (Cores 26-18) are similar in shell outline and dimensions to Dictyophimus archipilium. The difference is in the absence of the distinct abdomen in A. macropus group. This species-group exists from the latest Oligocene, being most numerous from the middle and late Miocene and Pliocene. In Quaternary they are rather rare.

\section{Genus PTEROCANIUM Ehrenberg}

Pterocanium Ehrenberg, 1847b, p. 54; Haeckel, 1881, p. 436; 1887, p. 1328; Campbell, 1954, p. 130; Petrushevskaya, 1971b, p. 228; Petrushevskaya and Kozlova, 1972, p. 552.=Pterocanarium Haeckel, 1887, p. 1329. Type species Pterocanium proserpinae Ehrenberg, 1872, pl. 11, fig. 22.

The thorax volumeless. The feet are perforated and the abdominal wall differs from the thoracic wall.

\section{Pterocanium sp.}

(Plate 25, Figures 6, 7)

Pterocanium trilobum sensu Hays, 1965, p. 177, pl. 3, fig. 10. (non $P$ trilobum Haeckel, 1887).

Occurs in the subantarctic Pleistocene sediments of Zone X.

\section{Family PTEROCORYIDAE Haeckel}

Pterocorida Haeckel, 1881, p. 435; Riedel, 1967b, p. 296; Petrushevskaya 1971 a, p. $986 ; 1971$ b, p. 230 ; Petrushevskaya and Kozlova, 1972, p. 543.

\section{Genus ANDROCYCLAS Jörgensen}

Androcyclas Jörgensen, 1905, p. 139; non Campbell, 1954, p. 130; non Petrushevskaya, 1971b, p. 231. Type species Pterocorys gamphonychos Jörgensen, 1900; 1905, fig. 92-97.

This genus is not the synonym of Pterocodon as Campbell suggested. It has its own type species. This species is very similar to Lamprocyclas, but it is possible that Androcyclas gamphonyxos descended independently possibly from Thyrsocyrtis bromia-Lamprocyclas (?) heteroporus Hays lineage) by the elongation of the cephalis. It is better to not consider it as the synonym of Lamprocyclas.

\section{Androcyclas heteroporus (Hays)}

(Plate 8, Figures 11-13; Plate 22, Figure 3)

Lamprocyclas heteroporus Hays, 1965, p. 179, pl. 3, fig. 1; Petrushevskaya, 1971b, pl. 117, fig. 4, 5; ?1973, pl. 3, fig. 25; Petrushevskaya and Kozlova, 1972, p. 545, pl. 36, fig. 6, 7.

\section{Genus LAMPROCYCLAS Haeckel}

Lamprocyclas Haeckel, 1881, p. 434; 1887, p. 1390; Campbell, 1954, p. 132; Nigrini, 1967, p. 74; Petrushevskaya, 1971b, p. 232; Petrushevskaya and Kozlova, 1972, p. 544.

Lamprocyclia Haeckel, 1887, p. 1390. Type species Lamprocyclas nuptialis Haeckle, 1887, pl. 74, fig. 15.
Theocorbis Haeckel, 1887, p. 1401; Campbell, 1954, p. 134; Petrushevskaya and Kozlova, 1972, p. 544. Type species Theoconus jovis Haeckel, 1887, pl. 69, fig. 4.

Craterocyclas Haecker, 1908, p. 456; Campbell, 1954, p. 127; Petrushevskaya and Kozlova, 1972, p. 544. Type species Craterocyclas robustissima Haecker, 1908, fig. 596.

Hexalodus Haecker, 1908, p. 456; Campbell, 1954, p. 134. Type species Hexalodus dendroporus Haecker, 1908, fig. 593.

\section{Lamprocyclas aegles (Ehrenberg) group}

(Plate 16, Figures 1-3)

Podocyrtis aegles Ehrenberg, 1854, pl. 35,B.IV fig. 18.

Lamprocyclas aegles (Ehrenberg) Petrushevskaya, 1971b, pl. 116, fig. 1, 2; Petrushevskaya and Kozlova, 1972, p. 544, pl. 36, fig. 14.

Pliocene(?)-Quaternary.

\section{Genus GONDWANARIA n. gen.}

Lipmanella Löeblich and Tappan, 1961; Petrushevskaya, 1971b, p. 198; Petrushevskaya and Kozlova, 1972, p. 542, (part). Type species Sethoconus (?) dogeli Petrushevskaya, 1967, pl. 53, fig. 1, 2, Petrushevskaya and Kozlova, 1972, pl. 37, fig. 10.

Cephalis is globe-shaped, settled on the "neck" (Figure $10 \mathrm{I}$ ). Thorax cupola-shaped. The upper walls of the thorax may have three ribs formed by the spines D, $L_{r}$ and $L_{1}$. There are no real "sethoperid" plates connecting these three spines with the apical horn. Abdomen may be more or less developed (and divided from the thorax). Pores irregular or in longitudinal rows. Differs from Pteropilium by the cephalis being "with the neck type". It seems probable that Gondwanaria is connected with the Cretaceous and Paleogene species of Lithomelissa (?) amazon Foreman, 1968, group (Petrushevskaya and Kozlova, 1972, pl. 37). If so, this genus may be regarded as Plagiacanthoidea. The similarity of some Gondwanaria species and the earliest Clathrocorona (typical Setoperid) is also great (Plate 9, Figures 1-6). The difference is mainly in the thoracic gates present in the most of Clathrocorona species.

\section{Gondwanaria japonica (Nakaseko) group}

(Plate 8, Figure 15; Plate 9, Figures 2-7; Plate 12, Figure 1)

Sethocyrtis japonica, Nakaseko 1963, p. 176, pl. 1, fig. 10, fig. 6; Nakaseko and Suchano, 1973, pl. 3, fig. 2.

Calocyclas asperium redondoensis sensu Petrushevskaya, ?1973, no. 9.

Thorax is nearly conical. Pores irregular, about 7-9 on the half of the equator of the thorax. Naturally lateral feet in some late Miocene individuals are arranged on the abdomen, not on the thorax. Nakaseko has shown the difference from Theocyrtis redondoensis Campbell and Clark: the latter has a nearly global thorax. Th. redondoensis might be placed among Calocyclas. Typical Th. redondoensis was not found in the DSDP Leg 29 Antarctic Miocene samples investigated.

\section{Gondwanaria deflandrei n. sp. group} (Plate 9, Figures 8, 9)

Dictyoceras xiphephorum Jörgensen sensu Petrushevskaya, 1971b, pl. 110, fig. 3. (non Dictyoceras xiphephorum Jörgensen, 1905).

The outline of the skeleton is very similar to $G$. japonica. The cephalis is with a neck. The thorax subconical, $70 \mu-100 \mu$ in width and in height. The upper part of the abdomen is slightly wider than the thorax. The two segments are separated by the inner ring. More pores on half of the equator of the thorax than in G. japonica (15-20), the main difference between the two species. The species differs from Dictyoceras xiphephorum in having cephalis with a neck. It differs from the specimens illustrated by Petrushevskaya and Kozlova, 1972, pl. 37, fig. 13,14 by a more defined shell outline and an obligate ring between thorax and abdomen.

In DSDP Leg 29 samples it occurs in early Miocene, but specimens of that group may be found in Quaternary deposits both in the Antarctic and in the North Atlantic. Description is based on nine specimens from Site 278 (Samples 29-4, $75 \mathrm{~cm}$; 29-3, $117 \mathrm{~cm} ; 28-4,40 \mathrm{~cm}$; and some additional samples). Holotype No. 62249. The species is named after George Deflandre. 
Gondwanaria hister n. sp.

(Plate 9, Figure 19; Plate 21, Figure 3)

Lipmanella (?) sp. M, Petrushevskaya and Kozlova, 1972, pl. 37, fig. 2, 3.

Cephalis with a neck. The thorax is subglobal or nearly ellipsoidal, about $60 \mu$; abdomen reduced. The number of the pores is the same as in G. japonica (about 7-9 on a half of the equator). Pores rather small, arranged far apart. The shell mouth is constricted.

In tropical Atlantic deposits the species is restricted to Calocycletta costata Zone; also in the middle Miocene in the Antarctic. The description is based on five specimens from Site 278 (Core 21), and some additional samples. Holotype No. 62250 in the Collection of Marine Hydrobiology. The sense of the species name is "tot"=little fellow.

\section{Gondwanaria dogeli (Petrushevskaya) group}

Sethoconus (?) dogeli Petrushevskaya, 1967, p. 95, pl. 53, fig. 1, 2. Pterocyrtidium dogeli (Petrush.) Petrushevskaya, 1972b, pl. 110 , fig. 1. Lipmanella (?) dogeli (Petrush.) Petrushevskaya and Kozlova, 1972, p. 542 , pl. 37 , fig. 10.

Differs from the species mentioned above by the companulate shell outline, having no subdivision into thorax and abdomen. It differs from these species also by its polygonal, large pores arranged near each other. The species appears in the Antarctic in early Miocene in the atypical form (Plate 25, Figure 5), and it is known to exist up to Recent.

\section{Family ARTOSTROBIIDAE Riedel}

Artostrobiidae Riedel, 1967a, p. 149; 1967b, p. 296; Petrushevskaya 1971 a, p. 985; 1971b, p. 235; Petrushevskaya and Kozlova, 1972, p. 538; Foreman, 1973, p. 430, 431.

Small or middle-size cephalis of a complicated type (Figure 10, VII), with high disposed branches $a$. Poor or multisegmented skeleton. It seems likely that the family descended from three-segmented eucyrtidids by means of the secondary segmentation of their abdomen. Pores in the transverse rows. No stout horns or feet. Cephalic tubes are common, as a rule there is a tube connected with the spine Vert, and sometimes a tube connected with the spine $A$.

\section{Genus LITHAMPHORA Popofsky}

Lithamphora Popofsky, 1908, p. 294; Campbell, 1954, p. 140; Petrushevskaya 1971b, p. 198; Petrushevskaya and Kozlova, 1972, pl. 539. Type species Lithamphora furcaspiculata Popofsky, 1908, pl. 36 , fig. 6-8.

The subdivision of the shell into postthoracic segments is variable, different in various species and specimens.

\section{Lithamphora quadrata Petrushevskaya and Kozlova} (Plate 10, Figures 19, 20)

Lithamphora sacculifera (Clark and Campbell) quadrata Petrushevskaya and Kozlova, 1972, p. 539, pl. 30, fig. 4-6.

Lithomitra docilis Foreman, 1973, p. 431, pl. 9, fig. 3-5, (Plate 8, Figure 20 (only)).

The pore arrangement (nearly quadrangular and without the longitudinal furrows) and the segmentation (few indistinct segments, each with many rows of the pores) are quite atypical for Lithomitra. Seems to originate from Theocampe species.

Paleocene-Eocene. The species, illustrated by Foreman (1973, pl. 8, fig. 21,22 ) is somewhat different, looking like Theocamptra species.

\section{Lithamphora corbula (Harting) group}

(?)Lithocampe corbula Harting, 1863, p. 12, pl. 1, fig. 21. Siphocampe corbula (Harting) Nigrini, 1967, p. 85, pl. 8, fig. 5 .

Siphocampe sp. aff. $S$. corbula (Harting) Riedel and Sanfilippo.

Rather variable species group in the Miocene. Likely both $L$. furcaspiculata (Recent Antarctic species) and L. corbula s. s. (Recent tropical species) descended from this thick-walled, irregular and variable, widely distributed Miocene species.

\section{Lithamphora sp.}

(Plate 10, Figure 21)

The cephalothorax is rather large, the postthoracic part is nearly cylindrical and similar to Lithamphora sp. aff. L. corbula (Harting), but the entire skeleton is smaller than in $L$. corbula group. Oligocene.

\section{Lithamphora furcaspiculata Popofsky}

Poroamphora paradoxa Popofsky, 1908, p. 294, pl. 36, fig. 5 . Dictyomitra meridionalis Popofsky, 1908, p. 293, pl. 36, fig. 3.

Lithamphora furcaspiculata Popofsky, 1908, p. 295, pl. 36, fig. 6-8; Petrushevskaya 1967 , p. 129; pl. 73 , fig. 1-3, pl. 74, fig. 1-4.

Siphocampium sp. Riedel, 1958, p. 243, pl. 4, fig. 9, 10. Quaternary.

\section{Genus BOTRYOSTROBUS Haeckel}

Botryostrobus Haeckel, 1887, p. 1475; Campbell, 1954, p. 141; Petrushevskaya and Kozlova, 1972, p. 539. Type species Lithostrobus botryocyrtis Haeckel, 1887, pl. 79, fig. 18.

Artostrobium Haeckel, 1887, p. 1482; Campbell, 1954, p. 140; Foreman, 1966, p. 355 , 1973, p. 430; Petrushevskaya, 1971b, p. 171.

\section{Botryostrobus joides n. sp.}

(Plate 10, Figure 37)

Botryostrobus sp. Petrushevskaya and Kozlova, 1972, p. 539, pl. 24, fig. 8-11.

Thick-walled shell with about three rows of pores on one segment. Pores nearly in checkerboard order. The constrictions between the segments are short. The surface of the cephalothorax rather rough. The description is based on 11 specimens from Sites 138 and 140, and 7 specimens from Holes 278 (Core 21), and 280A (6, CC). Holotype. No 62251 in the Marine Department. The species is named after the institutional organization for the Deep Sea Drilling Project.

\section{Botryostrobus euporus (Ehrenberg)}

(Plate 10, Figures 22-24)

(?)Eucyrtidium euporum Ehrenberg, 1872, pl. 4, fig. 20.

Lithocampe eupora (Ehrenberg) Haeckel, 1887, p. 1502; Petrushevskaya, 1967 , p. 141, pl. 80, fig. 1-5.

Dictyomitra caminosa Haeckel, 1887, p. 1500, pl. 79, fig. 12.

(?)Dictyomitra drigalskii Popofsky, 1908, p. 253, pl. 36, fig. 4.

(?)Lithomitra bramlettei Campbell and Clark, ?1944, p. 53, pl. 7, fig. 10-14 (only).

\section{Botryostrobus australis (Ehrenberg) group}

Petrushevskaya and Kozlova, 1972, p. 539, pl. 24, fig. 12-14.

The constrictions between the segments are deep, rather long, and without pores. The shell surface is rough. The fifth segment is narrower than the fourth.

Miocene-Recent(?).

Lithocampe australe $=$ Eucyrtidium australe Ehrenberg, 1854, pl. $35 \mathrm{~A}, 21$, fig. 18 seems to be similar to Lithocampe aurita Ehrenberg, 1854 , pl. 22 , fig. 25 .

\section{Botryostrobus tumidulus (Bailey) group}

(Plate 10, Figures 25-26)

Eucyrtidium tumidulum Bailey, 1856.

Dictyomitra monfereyana Campbell and Clark, 1944a, pl. 52, fig. 8. Botryostrobus tumidulus (Bailey) Petrushevskaya and Kozlova, 1972, pl. 24 , fig. 20, 21.

Differs from $B$. euporus by having a wider shell and shorter constrictions between the segments.

Miocene-Recent(?).

\section{Genus LITHOMITRA Bütschli}

Lithomitra Bütschli, 1882, p. 529; Haeckel, 1887, p. 1483; Campbell, 1954, p. 141; Petrushevskaya and Kozlova, 1972, p. 539.=Lithomitrella Haeckel 1887, p. 1483. Type species Lithomitra pachyderma Ehrenberg, 1873 (1875, pl. 11, fig. 21).

\section{Lithomitra imbricata (Ehrenberg) group}

Eucyrtidium imbricatus Ehrenberg, 1873, p. 229, pl. 11, fig. 22. Lithomitra lineata group Riedel and Sanfilippo, part.

Lithomitra imbricata (Ehr.) group Petrushevskaya and Kozlova, 1972, p. 539 , pl. 24 , fig. $2-5$.

Eocene-Oligocene, Miocene in the Antarctic. 
Lithomitra nodosaria Haeckel group

(Plate 10, Figure 18)

Lithomitra nodosaria Haeckel, 1887 , p. 1484 , pl. 79 , fig. 1; Petrushevskaya, 1967, pl. 83, fig. 8, 9; Kruglikova, 1969, pl. 4, fig. 3; Petrushevskaya and Kozlova, 1972, pl. 24, fig. 29, 30.

(?)Lithomitra embrionalis Vinassa de Regny, 1900, pl. 3, fig. 21.

(?)Lithomitra altamiraensis Campbell and Clark, 1944a, pl. 7, fig. 9. Oligocene-Quaternary.

\section{Lithomitra arachnea (Ehrenberg) \\ (Plate 10, Figures 13-17)}

Eucyrtidium lineatum arachneum Ehrenberg, 1862, p. 299.

Lithomitra vanhöffeni Popofsky, 1908, p. 296, pl. 36, fig. 9.

Theocampe sanpedroana Campbell and Clark, ?1944, p. 50, pl. 7, fig. 5.

Lithomitra arachnea (Ehrenberg) Riedel, 1958, p. 242, pl. 4, fig. 7, 8; Petrushevskaya 1962, p. 339, fig. 9, 10; 1967, p. 147, pl. 83, fig. 4, 5; 1969a, pl. 8, fig. 1-4.

Miocene-Recent.

\section{Lithomitra modeloensis (Campbell and Clark) group}

(Plate 10, Figure 9)

(?)Lithomitra laevigata Principi, 1909, p. 17, pl. 1, fig. 55.

Lithocampe modeloensis Campbell and Clark, ?1944, p. 59, pl. 7, fig. 28-30.

(?)Lithocampe uephelos Clark and Campbell, 1945, p. 59, pl. 7, fig. 19. Lithomitra lineata (Ehrenberg) Petrushevskaya, 1967, pl. 83, fig. 1. Lithomitra arachnea (Ehr.) Petrushevskaya, 1967, pl. 83, fig. 6.

On the third segment two rows of pores are usually united. The shell rather short and thin walled. Lithomitra modeloensis longa Campbell and..Clark (L. lineata [Ehr.] Petrushevskaya, 1967, pl. 83, fig. 2, 3 or L. clevei Petrushevskaya, ?1969, pl. 8, fig. 6) differs from L. modeloensis typ. by having a longer shell. Differs from Theocamptra sp. aff. Th. marylandica (Martin) (Petrushevskaya and Kozlova, 1972, pl. 23, fig. $22,23)$ by a less pronounced third segment. In Theocamptra marylandica group the third segment is distinctly separated by the inner rings. Miocene-Recent.

\section{Lithomitra sp. B \\ (Plate 10, Figures 11, 12; Plate 26, Figure 9; Plate 41, Figures 1-5)}

Very much the same as Lithomitra modeloensis, but 1.5 times bigger. The external spines $D$ and $L$ are more pronounced than in the other Lithomitra species.

\section{Family NEOSCIADIOCAPSIDAE Pessagno}

Neosciadiocapsidae Pessagno, 1969, p. 392; Petrushevskaya and Kozlova, 1972, p. 540.

\section{Genus CLATHROCYCLAS Haeckel}

Clathrocyclas Haeckel, 1881, p. 434; 1887, p. 1385; Campbell, 1954, p. 132; Foreman, 1968, p. 46; Petrushevskaya and Kozlova, 1972, p. $540 .=$ Clathrocyclia Haeckel, 1887, p. 1386. Type species Clathrocyclas principessa Haeckel, 1887, pl. 74, fig. 7.

Two or three segmented forms, with or without the velum. The difference from the type species of Lophoconus Haeckel (Eucyrtidium antilope Ehrenberg, 1872, pl. 8, fig. 18) is in the pore arrangement and the shell outline.

\section{Clathrocyclas sp. aff. L. titanothericeraos group,} Campbell and Clark

(Plate 15, Figures 21 and 24; Plate 23, Figure 1)

Lophoconus titanothericeraos Campbell and Clark, 41942, p. 89, pl. 8, fig. 24,30 , and 36 (only).

No flattened velum. The third segment (abdomen) may be present. It is cylindrical and as a rule closed. About $9-11$ pores in a transverse row on the thorax. In the Antarctic Miocene this species differs from the Eocene Clathrocyclas universa Clark and Campbell group (Plate 15, Figures 13-17; Plate 23, Figures 4-8; Plate 43, Figures 6, 7) by the better developed spine Vert, which usually forms a horn or tube in $C$. titanothericeraos. The difference from Eucyrtidium biauritum Ehrenberg group and E. bicorne Ehr. 1875 or from Lopophaena auriculaleporis Campbell and Clark (Plate 42, Figure 3) is greatest mainly in the structure of the wall.
The author is not sure if $C$. titanothericeraos group and $C$. universa group are very closely related: the spine Vert in their cephalises is different. On the other hand, both might have descended from the same ancestors. The Paleocene-Eocene species are illustrated on Plate 14, Figure 5, and Plate 15, Figure 7.

\section{Clathrocyclas bicornis Hays}

(Plate 15, Figure 25; Plate 23, Figure 3)

Clathrocyclas bicornis Hays 1965, p. 179, pl. 3, fig. 3.

Clathrocyclas bicornis Hays, in Bandy, Casey, and Wright, 1971, pl. 3,

fig. 4.

As a rule the third segment is undeveloped. The skeleton is a bit larger than in C. titanothericeraos. In the Antarctic specimens, the pores are nearly hexagonal; the transitional specimens (Site 281, Cores $8,9)$ have rounded pores and a smooth shell surface. The name of the species not good because of the existence of Clathrocyclas bicornis (Popofsky), but also because Hays' name was printed with the mistaken "Clatrocyclas bicornis" species name.

The species is very characteristic for the Antarctic and subantarctic late Miocene-Pliocene.

\section{Clathrocyclas bicornis (Popofsky) group}

(Plate 15, Figure 26; Plate 23, Figure 2)

Pterocorys bicornis Popofsky, 1908, p. 228, pl. 34, fig. 7, 8. Theocalyptra bicornis (Popofsky) Riedel, 1958, p. 240, pl. 4, fig. 4; Petrushevskaya, 1967, p. 126, pl. 71, fig. 2-7; Petrushevskaya and Kozlova, 1972, p. 540 , pl. 33 , fig. $11,12$.

Miocene-Recent (not Pliocene, as was initially suggested). If this species descended from C. titanothericeraos group or C. bicornis Hays, it occurred no later than the beginning of the Miocene. It is also possible that $C$. bicornis (Popofsky) as well as $C$. humerus n. sp. descended from the species similar to Neosciadiocapsa diabloensis Pessagno, ?1969. They have a similar shell outline as well as shell proportions and dimensions. The main difference of these two species from $N$. diabloensis is the presence of a stout Vert-horn in Clathrocyclas.

The difference from $C$. titanothericeraos is the presence of the velum, the absence of the abdomen, and the number of pores on the thorax is greater (12-15 in a transverse row). The outline of the shell in C. bicornis Hays and in C. bicornis (Popofsky) is a bit different.

\section{Clathrocyclas humerus $\mathbf{n}, \mathbf{s p}$.}

(Plate 15, Figures 7, 12, 22, 23; Plate 43, Figures 1, 2)

The number of pores (about 13 in the transverse row), the shell outline with the small velum, and the dimensions are the same as in $C$. bicornis (Popofsky). The distinguishing characteristics are the pronounced "shoulders" and thickened part of the thorax (Plate 15, Figure 7). It is very similar to the "shoulders" of the Paleocene species (Plate 15, Figures 18-20), but $C$. humerus has more pores. It is difficult to say if the shoulders may originate in different branches of Clathrocyclas independently (in parallel way), or if the two species, the Paleocene and $C$. humerus are closely related. The description is based on 46 specimens from Site 278 (Cores 12-30). Holotype No 676767 in Marine Department. Species name means "shoulder."

\section{Clathrocyclas cabrilloensis Campbell and Clark group} (Plate 15, Figures 27-29)

(?)Clathrocyclas (Clathrocycloma) cabrilloensis Campbell and Clark, 1944a, p. 48 , pl. 7 , fig. 1 (only).

Diplocyclas (?) sp. A Nakaseko, 1963, p. 178, fig. 11, pl. 2, fig. 3; 1970, pl. 2, fig. 10.

Clathrocyclas sp. A Nakaseko, 1970, pl. 2, fig. 7.

Very similar $C$. humerus, but with a spongy layer on the shell surface.

In the Antarctic in the late Miocene.

\section{Genus EUCECRYPHALUS Haeckel}

Eucecryphalus Haeckel, 1860 , p. $836 ; 1881$, p. 431 ; 1887, p. 1220 ; Campbell, 1954, p. 122; Petrushevskaya, 1971b, p. 222, part; Petrushevskaya and Kozlova, 1972, p. 540.

Eucecryphalium Haeckel, 1887, p. 1221; Campbell, 1954, p. 122. Type species Eucecryphalus gegenbauri Haeckel, 1862, pl. 5, fig. 12-15.

\section{Genus ANTHOCYRTELLA Haeckel}

Anthocyrtis Ehrenberg, ?1847, p. 54; Haeckel, 1887, p. 1269; Loeblich and Tappan, 1961, p. 228.=Anthocyrtella Haeckel, 1887, p. 1269; 
non Campbell, 1954; but Loeblich and Tappan, 1961, p. 228; Petrushevskaya and Kozlova, 1972, p. 541. Type species Anthocyrtis mespilis Ehrenberg, 1854, p. 36, fig. 13.

The third segment may be porous and only the fourth segment may represent by itself a latticed velum. Different from Clathrocyclas in the proportions (ratio) of the segments, and in the conical (not cylindrical) shell outline. Anthocyrtella (being a three-four segmented genus) is similar to Stichopilidium species (Plate 15, Figure 1). Different in the presence of outer spines along the thorax and abdomen in Stichopilidium.

\section{Anthocyrtella sp. A}

(Plate 15, Figure 2; Plate 16, Figure 5)

The first three segments are porous and the pores are very large, often irregular in the fourth segment. Some longitudinal ribs may be seen in the walls of the fourth segment. The first segment is the narrowest, the fourth is the broadest. All the segments are separated from one another by the inner ring and the external constriction.

Not very abundant but rather typical in the Antarctic Miocene. Some specimens with undeveloped fourth segment (which has very small pores) also occur (Plate 15, Figures 4, 5).

\section{Anthocyrtella (?) kruegeri (Popofsky)}

(Plate 25, Figures 9, 10

Corocalyptra kruegeri Popofsky, 1908, p. 289, pl. 35, fig. 8; 1913, p. 382 , fig. 96-98.

Eucyrtidioidea gen. sp. Petrushevskaya and Kozlova, 1972, pl. 25, fig. 3.

Conical shell outline. Cephalis as described by Foreman for $E c$ tonocorys (Figure 10, VIII). Pores in transverse rows. Early Miocene Form E were multi-segmented (Eucyrtidioidea gen. sp. Petrushevskaya and Kozlova). Late Miocene-Pliocene forms are three-segmented. In various forms of the species group, the number of the pores in a row is different. Several species or subspecies are to be described.

\section{Genus DIPLOCYCLAS Haeckel}

Diplocyclas Haeckel, 1881, p. 432; 1887, p. 1392; Campbell, 1954, p.

132; Petrushevskaya and Kozlova 1972, p. 540. Type species

Diplocyclas bicorona Haeckel, 1887, pl. 59, fig. 8.

It is very similar to Coniforma Pessagno, ?1969 (type species Coniforma antiochensis Pessagno, ?1969a, pl. 43, fig. 9-12) in having nearly the same dimensions and shell proportions. The main difference in Diplocyclas bicorona is the presence of a well-developed Vert-horn (the same difference as between Clathrocyclas bicornis (Popofsky) and Neosciadiocapsa diabloensis Pessagno). Diplocyclas bicorona differs from Clathrocyclas alomenae Haeckel, 1887, pl. 59, fig. 6, the type species of Clathrocycloma Haeckel 1887, only by a little more constricted shell mouth. Clathrocycloma may represent a synonym of Diplocyclas, although it is difficult to decide whether D. bicorona descended originally from two-segmented forms as Coniforma antiochensis Pessagno, or from three-segmented forms with the inner ring separating thorax and abdomen (compare Figures 1-3 and 4 on Plate 24).

Diplocyclas sp. aff. D. bicorona Haeckel group (Plate 15, Figures 8-10; Plate 24, Figures 1-3

Diplocyclas bicorona Haeckel, 1887, p. 159, fig. 8; Petrushevskaya and Kozlova, 1972 , p. 540 , pl. 33 , fig. $17,18$.

Cycladophora davisiana Ehr. cormutoides Petrushevskaya, 1967, pl. 70, fig. 1-3.

Cycladophora davisiana Ehr. semeloides Petrushevskaya, 1967, pl. 70, fig. 4-7.

Miocene-Recent.

Diplocyclas ionis (Haeckel) group

(Plate 15, Figure 11; Plate 24, Figure 6)

Clathrocyclas ionis Haeckel, 1887, p. 1389, pl. 59, fig. 9.

(?)Conarachnium isozakiense Nakaseko, 1963, pl. 1, fig. 9.

Diplocyclas ionis (Haeckel) Petrushevskaya and Kozlova, 1972, p. 541, pl. 33, fig. 13-16).

Miocene-Recent.

\section{Diplocyclas (?) davisiana (Ehrenberg)}

Cycladophora (?) davisiana Ehrenberg, 1862, p. 297; 1873, pl. 2, fig. 11; Petrushevskaya, 1967, p. 102, pl. 69.
Theocalyptra davisiana (Ehrenberg) Riedel, 1958, p. 239, pl. 4, fig. 2, 3; Petrushevskaya, $1971 \mathrm{~b}$, pl. 93, fig. 8,9 .

It is difficult to decide whether $D$, davisiana descended from $D$. bicornis group (from the specimens similar to one, illustrated by Petrushevskaya, 1967, pl. 70, fig. 4, which have a slight constriction in the middle of the shell), or from Diplocyclas sp. A group (Plate 24, Figure 4). In other words, if it originated by the deepening of the constriction in the middle of the shell or by the reducing of such constriction and of the inner ring.

Miocene-Recent.

\section{Diplocyclas sp. A}

(Plate 24, Figure 4)

Diplocyclas sp. A Petrushevskaya and Kozlova, 1972, p. 541, pl. 33, fig. 14-16.

The separation into thorax and abdomen in the middle of the shell generally may be pronounced. Rather variable Oligocene species. It seems likely that it originated from three-segmented Anthocyrtella species.

\section{Family PLECTOPYRAMIDIDAE Haecker}

Plectopyramidae Haecker, 1908, p. 457; Petrushevskaya, 1971a, p. 986; 1971 b, p. 225; Petrushevskaya and Kozlova, 1972, p. 550.

\section{Genus CORNUTELLA Ehrenberg}

Cormutella Ehrenberg, 1838, p. 128; Haeckel, 1881, p. 427; 1887, p. 1180; Campbell, 1954, p. 121; Petrushevskaya, 1967, p. 104, 1971b, p. 212; Petrushevskaya and Kozlova, 1972, p. $550 .=$ Cormutosa Haeckel, 1881, p. 427; 1887, p. 1183; Campbell, 1954, p. 121.=Cornutura Haeckel, 1881; Campbell, 1954, p. 121.

Cornutissa Haeckel, 1881 , p. $427 ; 1887$, p. 1181 . Type species Cormutella clathrata Ehrenberg, 1838, pl. 22, fig. 39.

Cornutanna Haeckel, 1881, p. 427; Campbell, 1954, p. 121.=Ortocor nutanna Clark and Campbell, 1945. Type species Cornutanna orthoconus Haeckel, 1887.

Ceratarachnium Haeckel, 1887 (pro Cormutellium Haeckel, 1881); Campbell, 1954, p. 128. Type species Sethoconus hexagonalis Haeckel, 1887.

\section{Cornutella profunda Ehrenberg group}

(Plate 13, Figures 32, 33)

Cornutella clathrata $\beta$ profunda Ehrenberg, 1854, pl. 35B.IV, fig. 24. Cornutella verrucosa Ehrenberg, 1872a, p. 287; 1872b, pl. 9, fig. 16; Petrushevskaya, 1967, p. 109, pl. 61, fig. 1-4.

$C$. verrucosa have more pores than the typical $C$. profunda illustrated by Petrushevskaya and Kozlova, 1972, pl. 30, fig. 19, 20. Miocene-Recent.

\section{Genus PERIPYRAMIS Haeckel}

Peripyramis Haeckel, 1881, p. 428; 1887, p. 1162; Campbell, 1954, p. 119; Riedel, 1958, p. 231; Petrushevskaya and Kozlova, 1972, p. 551. Type species $P$. circumtexta Haeckel, 1887 , pl. 54, fig. 5.

Peripyramis circumtexta Haeckel group

(Plate 13, Figure 29; Plate 44, Figures 5, 6)

Peripyramis circumtexta Haeckel, 1887, p. 1162; Riedel, 1958, p. 231, pl. 2, fig. 8, 9; Petrushevskaya, 1967, p. 113, fig. 64; Petrushevskaya and Kozlova, 1972, p. 551, pl. 31, fig. 4.

In the Antarctic they occur in the Oligocene, but typical specimens with the spongy layer are common only beginning from the middle Miocene (from Core 22, Site 278).

Miocene(?)-Recent.

\section{Family CARPOCANIIDAE Haeckel}

Carpocaniidae Haeckel, 1881, p. 427; Riedel, 1967b, p. 296; Petrushevskaya, 1971a, p. 988; 1971b, p. 238; Petrushevskaya and Kozlova, 1972, p. 535.

Small cephalis (Figure 10 (IX), rare, IV) of "cryptocephalic" type, with highly arranged branches $a$, and as a rule with well developed additional lobes, surrounding the main eucephalic camera. No stout apical horn. Cephalis is confused with the abdomen in a peculiar "cephalothorax", characteristic for the family. It differs from the cephalothorax of Theocampidae and Artostrobiinae by being ellipsoidal (not pyramidal or conical), and having longitudinal (not 
transverse) rows of pores. Abdomen may be reduced. Cretaceous-Recent.

\section{Genus CYSTOPHORMIS Haeckel}

Cystophormis Haeckel, 1887, p. 1165; Campbell, 1954, p. 118; Petrushevskaya and Kozlova, 1972, p. 535. Type species Cystophormis pyla Haeckel, 1887, pl. 52, fig. 1.

Carpocanistrum Haeckel, 1887, p. 1170; Riedel and Sanfilippo, 1971, p. 1596; Petrushevskaya and Kozlova, 1972, p. 535. Type species Carpocanistrum evacuatum Haeckel, 1887, pl. 52, fig. 11.

Sethamphorus Haeckel, 1887, emend. Burma, 1959, p. 327. Type species Sethamphora favosa Haeckel, 1887, pl. 57, fig. 4.

Abdomen in the form of a peristome. Thorax is thick-walled. Additioial cephalic lobes are well developed.

\section{Cystophormis brevispina (Vinassa de Regny) group}

(Plate 13, Figures 3-7; Plate 44, Figures 1, 2)

Carpocanistrum brevispina Vinassa de Regny, 1900, pl. 2, fig. 23. Sethocorys sp. Hays, 1965, p. 177, pl. 3, fig. 8.

Sethocorys odysseus Haeckel sensu Petrushevskaya and Kozlova, 1972, pl. 22, fig. 16

Carpocanarium sp. O, Petrushevskaya, ?1973, p. 1044, p. 8, pl. 3, fig. $10,11$.

Peristome rather long and usually with furrows. About 9-11 longitudinal rows of the pores on a half of the equator. There are two forms: one typical, very regular (odysseus form), and the other less regular (form A)

Oligocene-Miocene.

Cystophormis ob n. sp.

(Plate 13, Figures 1, 2)

Cephalis rather thin-walled, distinctly multilobated. Peristome short. About 6-8 longitudinal rows of the pores on a half of the equator of the thorax. Pores arrangement may be irregular. Pores rather large, 3-5 in one row.

Miocene. Early Miocene specimens have thicker walls than the typical middle-late Miocene specimen.

Description is based on 13 specimens from Site 278 (Core 12, Section 1 to Core 26, Section 6). Holotype No. 63217 in the collection of Marine Hydrobiology of Zoological Institut. Form B species is named after the Soviet Explorer Antarctic Ship $O b$.

Species differs from all known species of Carpocanids by the fewer pores and the thin-walled cephalis. It is closer to $C$. favosa gr., the difference being the absence in $C$. ob of the characteristic for $C$, favosa peristom and the fewer number of large pores in $C . o b$.

\section{Genus TRICOLOCAPSA Haeckel}

Tricolocapsa Haeckel, 1881, p. 436; 1887, p. 1431; Campbell, 1954, p. 136; Petrushevskaya, 1971b, p. 198; Petrushevskaya and Kozlova, 1972, p. 537. $=$ Theocapsula Haeckel, 1887, p. 1432; Campbell, 1954, p. 136. Type species Tricolocapsa theophrasti Haeckel, 1887, pl. 66 , fig. 1 .

Carpocanarium Haeckel, 1887, p. 1279; Campbell, 1954, p. 127; Riedel and Sanfilippo, 1971, p. 1599; Petrushevskaya and Kozlova, 1972 p. 537. Type species Carpocanarium calocyclothes Stöhr, 1880, pl. 3, fig. 8 .

Diagnosis: Carpocaniids without well developed additional cephalic lobes. Abdomen is a peristome in the Neogene species.

\section{Tricolocapsa papillosa (Ehrenberg) group} (Plate 13, Figure 13)

Eucyrtidium papillosum Ehrenberg, 1872a, p. 310; 1872b, pl. 7, fig. 10. Dictyocephalus papillosus (Ehr.) Haeckel, 1887, p. 1307; Riedel, 1958, p. 236, pl. 3, fig. 10; Petrushevskaya, 1967, p. 114, fig. 66; ?1969c, pl. 8 , fig. 7-13.

Dictyocryphalus papillosus (Ehr.) Nigrini, 1967, p. 63, pl. 6, fig. 6 .

Tricolocapsa papillosa (Ehr.) Petrushevskaya, 1971b, p. 175 Petrushevskaya and Kozlova, 1972, p. 537, pl. 22, fig. 31, part. Miocene-Recent.

\section{Tricolocapsa bergontiana (Carnevale)}

(Plate 13, Figure 14)

Dictyocephalus bergontianus Carnevale, 1908, p. 32, pl. 4, fig. 20 . Differs from $T$. papillosa by having more pronounced and additional cephalic lobes.

Oligocene-Miocene.

\section{Superfamily CANNOBOTRYOIDEA Haeckel}

Cannobotryidae Haeckel, 1881, p. 446; emend. Riedel, 1967b, p. 296; Petrushevskaya, 1971a, p. 988; 1971b, p. 154; Petrushevskaya and Kozlova 1972, p. 554.

Large cephalis (no less than $30 \mu-40 \mu$ ) of the type on Figure 10, VI, VII. Branches $a$ are arranged more or less low. Eucephalic lobe usually with the neck, but sometimes the neck and the apical-dorsal part of the antecephalic lobe may be undeveloped (in the case of rather high arranged branches $a$ ). As a rule only two segments, sometimes the third segment, abdomen, are present. Multisegmented species very rare.

Cretaceous-Recent.

\section{Genus BOTRYOCYLINDER n. gen.}

Type species Bisphaerocephalina (?) apimelos Foreman, 1968, fig. 1, 8, pl. 6, fig. 1 .

Multilobated cephalis rather variable. Branches $a$ go from the middle of the height of the cephalis. Eucephalic and the antecephalic lobes are the same height. Cephalis about $30 \mu$ high. Thorax and abdomen and some other segments may be present. Pores on the segments in the transverse rows. The segments are separated by the internal rings. All the segments of nearly equal size and shape. The entire skeleton shape is a cylinder. Genus differs from Artostrobids by the low arranged branches $a$ (and by the connection of this with other peculiarities of the cephalis), and by the absence of the "cephalothorax," characteristic for the Artostrobids.

Genus is distinguished by its multisegmented skeleton. It may be more closely related to Eucyrtidioidea than real Cannobotryoidea.

Cretaceous-Paleogene. Species Diplostrobus facer Kozlova, 1966 (see Petrushevskaya, 1971b, p. 158, pl. 81, fig. 1) and the species on Plate 13, Figure 8, and Plate 26, Figure 11.

\section{Genus BOTR YOCAMPE Ehrenberg}

Botryocampe Ehrenberg, ?1860, p. 829; Haeckel, 1881, p. 440; 1887, p. 1122; Campbell, 1954, p. 144; Petrushevskaya, 1971b, p. 159. Type species Lithobotrys inflata Bailey, 1856, pl. 1, fig. 15 (and Plate 13, Figures 24, 25).

Eucephalic lobe with neck, subdivided into upper and lower parts. Branches $a$ are arranged on the middle of the height of the eucephalic lobe. Antecephalic lobe approximately of the same height as the eucephalic. Cephalis is separated from the thorax by the basal plate. Thorax may be subdivided but there is no real abdomen. The thorax is the largest part of the ellipsoidal shell. The walls are smooth, thick, with rare irregular pores.

Tertiary-Recent.

\section{Botryocampe conithorax (Petrushevskaya) group} (Plate 13, Figure 27)

Saccospyris conithorax Petrushevskaya, 1965, p. 98, fig. 11. Botryocampe conithorax (Petrush.) Petrushevskaya, 1971b, p. 156, pl. 79 , fig. 4.

Pliocene-Recent.

\section{Genus BOTRYOCELLA Haeckel}

Botryocella Haeckel, 1881 , p. 440; 1887, p. 1116; Campbell, 1954, p. 144, Petrushevskaya, 1971b, p. 161; Petrushevskaya and Kozlova, 1972, p. 554. Type species Lithobotrys nucula Ehrenberg, 1875, pl. 3 , fig. 16.

Eucephalic lobe with neck, antecephalic lobe much higher than eucephalic. Basal plate indistinct. Cephalis is the largest part of the shell. The walls are smooth, thick, with irregularly arranged pores.

Tertiary. 


\section{Botryocella (?) appenninica Vinassa de Regny group}

(Plate 13, Figures 16, 23)

(?)Botryocella appenninica Vinassa de Regny, 1900, pl. 2, fig. 38.

(?)Lithobotrys galea Ehrenberg, ?1844, p. 83.=Lithocorythium galea Ehrenberg, ?1847, 1854, pl. 22, fig. 29.

If Botryocella appenninica and Lithobotrys galea Ehrenberg are the synonyms, this species must be named Lithocorythium galea Ehr. because L. galea is the type species of Lithocorythium Ehrenberg, 1844. In the Antarctic Oligocene.

Very much the same as Botryocella cribrosa (Ehr.) (Petrushevskaya and Kozlova, 1972, pl. 39, fig. 4-6) group (non Lithobotrys cribrosa Ehr. in Petrushevskaya, 1971b, p. 160, pl. 82, fig. 4).

\section{Botryocella (?) sp. K \\ (Plate 13, Figure 17)}

Cannobotryid gen. sp. indet. Sanfilippo and Riedel, 1973, pl. 21, fig. 7, 8.

The shell proportions and the cephalic lobe ratio are the same ast $\mathrm{sn}$ Botryopyle species. The antecephalic lobe outline (narrower and elongated to the apex) is similar to that in Botryocella appenninica. The characteristic feature is the acute, stout apical horn, and robust external spines $D$ and $L$.

Eocene at Site 281

\section{Genus BOTRYOPYLE Haeckel}

Botryopyle Haeckel, 1881, p. 440; 1887, p. 1112; Popofsky, 1913, p. 318; non Campbell, 1954, p. 144; Petrushevskaya, 1965, p. 87, 1971 b, p. 161. Type species Botryopyle dictyocephalus Haeckel, 1887, pl. 96, fig. 6.

Acrobotryssa Popofsky, 1913, p. 321; Campbell, 1954, p. 144. Type species Acrobotryssa cribrosa Popofsky, 1913, fig. 29.

Eucephalic lobe with neck. Antecephalic lobe much larger than the eucephalic. Basal plate more distinct and thorax is better separated from the cephalis than in Botryocella, but in the other characteristics seems very similar to Botryocella. It seems likely that Botryopyle is closely related to Botryocella. The shell is smooth.

Miocene(?)-Recent.

\section{Botryopyle sp. A}

(Plate 13, Figure 22)

The enormous eucephalic lobe. In all other Cannobotryods, it is smaller, usually of standard size. Antecephalic lobe is much bigger than the eucephalic. Abdomen generally is well developed.

Late Miocene.

Botryopyle (?) dionisi n. sp. (Plate 13, Figure 18; Plate 26, Figure 10)

The shell is laterally flattened and very thick-walled. The surface of the eucephalic lobe and even the surface of the antecephalic lobe is a little rough, untypical for the genus. The height of the antecephalic lobe is up to $75 \mu$. Postcephalic part as a short tube. Spine $D$ is not perpendicular to the spine $A$, but the angle is about $130^{\circ}$. The maximum shell width is up to $90 \mu$.

Early Miocene.

Description is based on 35 specimens from Site 278, Cores 25-29. Holotype No. 63216 in the collection of Marine Hydrobiology Department.

\section{Genus SACCOSPYRIS Haecker}

Saccospyris, Haecker, 1908; non Campbell, 1954, p. 116 . Petrushevskaya, 1965, p. 95; 1967, p. 151. Type species Saccospyris antarctica Haecker, 1907 (1908, pl. 84, fig. 584, 589, 590).

Antecephalic lobe is nearly the same height as the eucephalic. The eucephalic lobe with the neck is of typical Botryoid structure. Two segments. Basal plate between them is well developed and complicated. The cephalic walls and the upper part of the thorax are rough.

Miocene-Recent.

\section{Saccospyris preantarctica n. sp.}

(Plate 13, Figures 19, 20)

Saccospyris sp. Petrushevskaya, 1972, pl. 2, fig. 7; ?1973, p. 1044, no. 28 , pl. 3, fig. 13 .
Rather thin-walled Saccospyris. Postcephalic tube and outer spines $A, D, L$ are more pronounced than in $S$. antarctica. The shell outline is less compact than in $S$. antarctica.

In Antarctic Miocene.

Description is based on 21 specimens from Site 278 (Cores 12-27) and some additional materials. Holotype No. 63215 in the Collection of Marine Hydrobiology Department.

\section{Saccospyris antarctica Haecker \\ (Plate 13, Figures 21, 28)}

It differs from Botryocampe spp. (Plate 13, Figures 24-26) by having antecephalic lobe shorter than the eucephalic lobe, and by the greater size. Very thick walls. No real outer spines. The angle between the spines $A$ and $D$ is $120^{\circ}-130^{\circ}$.

\section{Superfamily PLAGIACANTHOIDEA Hertwig}

Plagiacanthoidea Hertwig, Petrushevskaya, 1971a, p. 989; 1971b, p. 57; Petrushevskaya and Kozlova, 1972, p. 534.

Cephalis is no less than about $30 \mu$, generally about $50 \mu$ or more. Usually it is no less than $1 / 3$ of the whole skeleton.

\section{Family SETHOPERIDAE Haeckel}

Sethoperidae Haeckel, 1881, p. 433; 1887, p. 1232; Haecker, 1908, p. 448; Petrushevskaya, 1971a, p. 989; 1971b, p. 76; Petrushevskaya and Kozlova 1972, p. 535.

Diagnosis: Cephalis of a medium size $(20 \mu-50 \mu)$. This is why many species are rather typical to Eucyrtidioidea, not to Plagiacanthoidea. The cephalis is wide, conical, or subglobal, with internal columella going in its cavity (Figure 10, II, III, or VIII) with low branches arranged or even with the undistinct neck. The skeleton is two- or threesegmented, rarely multisegmented. In three- and multisegmented species the cephalis is small compared with the whole skeleton, also untypical for Plagiacanthoidea.

The pores are arranged in transverse rows. The latticed plates between the spines $A, D, L_{r}$, and $\mathrm{L}_{1}$ are most characteristic for the family, though they may be undeveloped in some species.

Cenozoic. Genera: Pteropilium Haeckel, Clathrocorona Haeckel, Clathrocanium Ehrenberg, Callimitra Haeckel, and possibly Lipmanella Loeblich and Tappan.

Differs from Pterocoryidae by the transverse pore arrangement, globe-shaped upper part of the cephalis in the case of the "cephalis with neck," the greater tendency to reduction of the postthoracic segments, and the latticed plates instead of the thorax as in the most genera.

\section{Genus CLADOSCENIUM Haecke}

Cladoscenium Haeckel, 1881, p. 429; 1887, p. 1148; non Campbell, 1954, p. 118. Type species Cladoscenium ancoratum Haeckel, 1887, pl. 53, fig. 13; Petrushevskaya, 1971b, fig. 40.

Sethoperids without typical latticed plates. The cephalis is the best developed part of the skeleton.

\section{Cladoscenium (?) advena (Clark and Campbell) group}

(Plate 11, Figure 16; Plate 24, Figure 7)

(?)Tripilidium longipes brevipes Clark and Campbell, 1942, p. 63, pl. 9, fig. 26.

Tripilidium clavipes advena Clark and Campbell, 1945, p. 34, pl. 7, fig. 31 , only.

Tripodiscium clavipes (Clark and Campbell) Petrushevskaya 1971b, fig. 34, VI.

Pores are very small, irregular, the feet short. Thorax with pores. Eocene; in the Antarctic, Oligocene.

\section{Family LAMPROMITRIDAE Haeckel}

Lampromitridae Haeckel, 1881, p. 431; Petrushevskaya and Kozlova, 1972, p. 534.

Cephalis is big or medium-size with high arranged branches $a$ (Figure 10, VIII, IX), and well-developed additional parts. Thorax wide.

\section{Genus CORYTHOMELISSA Campbell}

Corythomelissa Campbell, 1951, 1954, p. 124.=Sethomelissa Haeckel, 1887, p. 1205 (non p. 1235). Type species Lithomelissa corythium Ehrenberg, 1873; 1875, pl. 3, fig. 12. 
Tripodiscium Haeckel, 1881 sensu Petrushevskaya, ?1971a, p. 70, part; Petrushevskaya and Kozlova, 1972, p. 534.

Conical shell with three lateral feet and with apical horn. The surface is not smooth (as in the type species of Tripodiscinus - T. tristylospyris Haeckel, 1887, p. 1143) and the apical horn is distinct. Genus Spongomelissa Haeckel has the cephalis more separated in its lower part from the thorax (Butschli, 1882, pl. 33, fig. 25c; Petrushevskaya, 1971b, fig. 33, XII, XIII), than in Corythomelissa (Petrushevskaya, 1971b, fig. 33, VII, 35, I, II).

Corythomelissa horrida n. sp. group

(Plate 11, Figures 14, 15; Plate 21, Figure 9)

Differs from Spongomelissa cucumella Sanfilippo and Riedel (1973, pl. 19 , fig. 6,7$)$ by the smaller dimensions and by a more horny surface. Pores are rather large, irregular, about 5-7 pores between the outer spines $D$ and $L$ or $L_{\mathrm{r}}$ and $L_{1}$. Feet are three-bladed and curved. Antarctic Oligocene-Miocene.

Description is based on 12 specimens from Site 278. Holotype No. 6267 in Marine Hydrobiology Department.

\section{Corthomelissa sp. aff. Spongomelissa adunca Sanfilippo and Riedel} (Plate 21, Figure 8)

Spongomelissa adunca Sanfilippo and Riedel, 1973, pl. 34, fig. 1.

Surface has very small, numerous, irregular pores and spongy layer on the cephalis and on the upper part of the thorax. In outline the skeleton is similar to Tripodiscium sp. (Petrushevskaya and Kozlova, 1972, pl. 37, fig. 16).

Tropical Oligocene species.

\section{Genus LITHOCAMPANA Clark and Campbell}

Lithocampana Clark and Campbell, 1942, p. 66; Campbell, 1954, p. 128. Type species Lithocampana lithoconella Clark and Campbell, 1942, pl. 9, fig. 24.

High conical shell, two segmented, but the lower part of the cephalis is hidden in the upper part of the thorax and there is no outer constriction. The second segment may be subdivided into thorax and abdomen, not by the inner ring, but the external constriction. The arrangement of the pores is not stable in all species and it is not characteristic for the genus as a whole. Axobat is unknown.

\section{Lithocampana sp. aff. L. lithoconella Clark and Campbell} (Plate 11, Figure 1)

(?)Lithocampana lithoconella Clark and Campbell, 1942, p. 66, pl. 9, fig. 24.

The surface is smooth. Pores in checkerboard order. In some specimens the shell mouth is constricted. The entire skeleton with its irregular outline of the cephalic (Cryptocephalis) and with its longitudinal rows of the pores, looks similar to Carpocaniid skeleton.

\section{Genus BOTRYOMETRA n. sp.}

Type species Lithomelissa heros Campbell and Clark (Foreman, 1968, pl. 3, fig. 5) or Petrushevskaya, 1971b, pl. 79, fig. 1, 2.

Two-segmented ellipsoidal skeleton, the second segment (thorax) larger than the cephalis if the shell is complete. Thorax may be incomplete or reduced. In these cases cephalis and thorax are equal. Pores are few and irregular. Cephalis with branches $a$ in the upper part (Figure 10, VIII), Cephalis is more or less separated from the thorax. The spine $A$ goes in the cephalis as the columella. There is no distinct subdivision into cephalic lobes. Eucephalic and antecephalic parts of the equal height. The spines A, D, L may go outside as horns and lateral feet.

The Cretaceous species of the genus seem to be related to some Cannobotryoids: Bisphaerocephalina, Botryocampe, which have the same shell walls.

Cretaceous-Tertiary.

\section{Botryometra poljanskii n. sp.}

(Plate 13, Figures 9, 10; Plate 21, Figure 7; Plate 26, Figure 13)

Cephalis about $40 \mu$ in height with the broadest axis up to $60 \mu$; separated from the thorax by the basal plate. (This is the main difference from Lithomelissa heros.) The thorax is cylindrical. The lateral feet formed by the spines $\mathrm{D}$ and $\mathrm{L}$ are weak.

Late Miocene of the Antarctic.
Description is based on nine specimens from DSDP Site 278, Core 12. Holotype No. 63214 in collection of the Marine Hydrobiology Department of the Zoological Institute of the Academy of Sciences. Species is named after professor of the State University of Leningrad, George Poljansky who is also the head of Soviet protozoologists.

\section{Botryometra (?) spongiosa n. sp.}

(Plate 13, Figure 11)

The cephalis construction is very similar to Botryometra poljanskii but is larger. The constriction between cephalis and thorax is distinct. Thorax is wide, long, and subcylindrical. The entire shell is covered with a spongy layer very similar to the Botryocyrtis species. Apical horn is stout and the feet are weak.

Oligocene in the Antarctic.

Holotype No. 63123 in the Marine Department. Description is based on 11 specimens from Core 278-31, Section 3; Sample 280A-6, CC; and Core 281-16, Section 3.

\section{Genus ORBULA Foreman}

Orbula Foreman, 1973, p. 437. Type species $O$. ducalis Foreman, 1973, pl. 10, fig. 11, 12 .

The species with the pronounced feet $(O$. comitata and $O$. discipulus) seem to be more closely related with the Lychnocanids (Becoma, Pterocanium, Lychnocanium), but the type species of the genus Orbula seem to be related with Lampromitrids. The thorax with the terminal ring is known in Lampromitra. The three thoracic ribs (not Lychnocanid feet) are also common in Lampromitrids. Only the cephalis of $O$. ducalis is untypical for Lampromitrids, because it has the pedestal. On the other hand it is impossible to regard the cephalic structures to be stable and unsubmitted to evolution. In the shell proportions $O$. ducalis is generally similar to Lampromitra and Ceratocyrtis. The distinguishing character is the basely constricted thorax of Orbula. The species Eucyrtidium ampulla Ehrenberg, 1875, pl. 10, fig. 11,12 seems to belong in Orbula.

Orbula (?) sp.

(Plate 21, Figure 11)

Huge skeletons with horny, irregular surface, very much similar to Corythomelissa horrida, but without feet and somewhat larger. Cephalis with high arranged branches $a$, typical for lampromitrids. The upper part of the thorax with the normal pores and no "pedestal" can be seen.

Oligocene-Miocene in Antarctic.

\section{Genus CERATOCYRTIS Butschli}

Ceratocyrtis Butschli, 1882, p. 536; non Haeckel, 1887, p. 1290; Petrushevskaya, 1971b, p. 98; Petrushevskaya and Kozlova, 1972, p. 534. Type species Cornutella cucullaris Ehrenberg, 1873; 1875, pl. 2 , fig. 7.

Helotholus Jörgensen, 1905, p. 137; Campbell, 1954, p. 124. Type species Helotholus histricosa Jörgensen, 1905, fig. 86-88.

Bathrocalpis Clark and Campbell, 1942, p. 82; Campbell, 1954. Type species Bathrocalpis campanula Clark and Campbell, 1942, pl. 9, fig. 27.

Wide-conical shell with large, irregular variable pores. Eucephalic lobe is partly hidden in the thorax. Great axobate in the shell. The type species are illustrated by Petrushevskaya, 1971b.

Eocene-Recent.

\section{Ceratocyrtis amplus (Popofsky) group}

(Plate 11, Figures 3-6, 13; Plate 19, Figure 2; Plate 44, Figure 4)

Helotholus amplus Popofsky, 1908, p. 283, pl. 34, fig. 3 .

Apical horn rather stout. There are about $5-8$ pores on a half of the equator of the shell at the level of MB. No outside spines $D, L_{1}$, and $L_{r}$. No ribs in the walls. Somewhat similar to the Miocene Pseudodictyophimus sp. A in Petrushevskaya and Kozlova, 1972, pl. 37, fig. 19, 20.

Oligocene-Pleistocene. In the Antarctic Miocene very abundant. In Quaternary very rare, with short, thin skeletons.

Ceratocyrtis sp.

(Plate 11, Figure 12; Plate 18, Figures 1-3; Plate 19, Figure 1)

(?)Bathrocalpis rhabdophora rhabdophora Clark and Campbẹll, 1945, p. $34-35$, pl. 7, fig. 37-41. 
The shell dimensions and outline are very similar to $C$. amplus. The number of pores is greater, about 9-11 on a half of the shell at the level of the MB. The pores are smaller than in $C$. amplus. In the lower part of the skeleton, longitudinal ribs are common.

Miocene-Pleistocene.

\section{Ceratocyrtis sp. aff. Cornutella cucullaris, Ehrenberg} (Plate 11, Figure 2)

(?)Cornutella cucullaris Ehrenberg, 1873; 1875, pl. 2, fig. 7.

Eocene-Oligocene.

Genus ANTARCTISSA Petrushevskaya

Antarctissa Petrushevskaya, 1967, p. $85 ; 1971$ b, p. 120. Type species Lithobotrys denticulata Ehrenberg, 1844.

\section{Antarctissa (?) strelkovi Petrushevskaya} (Plate 18, Figure 5)

Helotholus histricosa sensu Popofsky, 1908, p. 278, pl. 32, fig. 1-5, pl. 36 , fig. 2; Riedel, 1958, p. 234, pl. 3, fig. 8.

Antarctissa strelkovi Petrushevskaya, 1967, p. 89, pl. 51, fig. 3-6.

It seems very likely that $A$. strelkovi originated from Ceratocyrtis sp. $\mathrm{R}$ by reducing the length of its characteristic thorax with numerous ribs, and enlarging the eucephalic part of the cephalis (compare Figures 4, 5, 6 on Plate 18).

Miocene-Recent.

\section{Antarctissa (?) longa (Popofsky)}

(Plate 11, Figures 8-10; Plate 18, Figure 6)

Helotholus longus Popofsky, 1908, p. 282, pl. 34, fig. 2.

Antarctissa longa (Popofsky) Petrushevskaya, 1967, p. 91, pl. 51, fig. 1. Pliocene-Recent.

In Paleocene-Miocene deposits, specimens (Plate 11, Figure 7) are known which are rather similar to $A$. (?) longa in the shell proportions and the presence of the horns on the top of the cephalis. The author does not think $A$. longa originated from these forms. It seems closely related to $A$. strelkovi and Ceratocyrtis.

\section{Antarctissa clausa (Popofsky} (Plate 24, Figure 9)

Helotholus histricosa Jörgensen var. clausa Popofsky, 1908, p. 281, pl. 34 , fig. 1.

Antarctissa denticulata (Ehr.) clausa Popofsky, Petrushevskaya, 1967, p. 87 , pl. 49 , fig. $5 ; 1971$ b, pl. 64 , fig. 2 .

$A$. clausa seems to be very similar to $A$. denticulata. A. clausa may have descended from Ceratocyrtis amplus by the closing of the mouth. If so, $A$. clausa and $A$. denticulata are not closely related.

\section{Antarctissa cylindrica n. sp.}

(Plate 11, Figures 19, 20)

Antarctissa denticulata var. cylindrica Petrushevskaya, 1967, p. 89, pl. 49, fig. 6, pl. 50, fig. 1; 1971b, pl. 64, fig. 3, 4 (only).

Antarctissa cylindrica Petrushevskaya, 1972a, pl. 1, fig. 8, pl. 2, fig. 6; ?1973, p. 1044 , pl. 3.

Surface nearly spongy (in $A$. clausa the walls are very thick but the surface nearly smooth). The rounded outline is nearly the same as in A. clausa. The additional lobes are very distinct. It is difficult to formulate the characters of this species but it is very abundant in the Antarctic Pliocene. It might have originated from late Miocene $A$ capitata (Popofsky) group.

The description is based on 67 specimens. Holotype No. 63122 in the Marine Department.

\section{Antarctissa denticulata (Ehrenberg)}

For synonymy see Petrushevskaya, 1967, p. 87.

It is possible that $A$. denticulata originated from $A$. (?) equiceps or $A$. capitata groups. Typical $A$. denticulata has small teeth on the margin of the flattened (basal) thorax. A. denticulata is larger than A. (?) equiceps, with thicker walls.

Pleistocene-Recent.

\section{Antarctissa (?) robusta n. sp.}

(Plate 11, Figures 21, 22)

Cyrtoidea gen sp. Petrushevskaya, 1967, pl. 50, fig. 2.

Thick-walled nearly cylindrical shell. Cephalis and thorax nearly equal. Pores are few, axobat is well-developed. Mouth closed by flat plate, very similar to $A$. denticulata. Different from $A$. denticulata in smaller dimensions and in cylindrical (not triangular or pyramidal) shell outline. Different from $A$. cylindrica in surface smoothness and in flat shell mouth. The name means solid, hard, robust. The description is based on 28 specimens from Site 278 (Core 12 and some others). Holotype No. 63636 in the Marine Department.

Remarks: The species is typical for the late Miocene in the Antarctic, but in the upper Oligocene deposits (Sample 278-31-3, $40 \mathrm{~cm}$ ) some specimens with the same cephalis and thorax were found. They differ by the presence of the abdomen the same size as the thorax separated by inner septa. It is possible that two-segmented $A$. (?) robusta descended from three-segmented ancestors.

\section{Antarctissa (?) capitata Popofsky}

(Plate 11, Figure 24; Plate 18, Figures 8, 9; Plate 19, Figure 6; Plate 20, Figures 1, 2)

(?)Lithomelissa capitata Popofsky, 1908, p. 278, pl. 31, fig. 13, only. Very much the same as $A$. (?) robusta, but numerous pores and a spongy surface; thin walls. The author believes $A$. (?) robusta and $A$. (?) capitata belong in the same genus. It cannot be Lithomelissa, because they have little in common with real Lithomelissa (Plate 11, Figure 26; Petrushevskaya, 1971b, pl. 44) with its high eucephalic lobe, pronounced "neck", spine $A$ as an inner columella, and the apical horn in Lithomelissa.

\section{Antarctissa equiceps Campbell and Clark group}

(Plate 11, Figures 23, 25)

(?)Dictyocephalus equiceps Campbell and Clark, 1948, p. 46, pl. 6, fig. 15.

Very similar to $A$. (?) robusta in all features, but smaller, with thin walls.

Common in the Antarctic Miocene.

Remarks: This species cannot be placed in the genus Dictyocephalus or Lithomelissa but the author is not clear whether to place it in Botryopera; it seems to be closely related to A. robusta.

\section{Genus BOTRYOPERA Haeckel}

Botryopera Haeckel, 1887, p. 1108; non Campbell, 1954, p. 143. Type species B. cyrtoloba Haeckel, 1887, pl. 96.

Trisulcus Popofsky, sensu Petrushevskaya, 1971b, p. 140, part. (Trisulcus borealis, T. braevispicula, $T$. boldyrae).

The most typical species-group of the Genus is Lithobotrys triloba Ehrenberg, 1854, pl. 19, fig. 35, pl. 22, fig. 30a, or Botryocella borealis Ehrenberg, 1872. Considering the above, the skeletons of these species look very much the same as on the Haeckel's drawing. Trisulcus triacanthus (Type species of $T$. sulcus) represents another branch of these Dicyrtids. It seems likely that they descended from threesegmented Cyrtids.

Remarks: It is difficult to understand why Campbell decided that Botryopera is the synonym of Lithobotrys. Campbell did not designate the type species for Botryopera but only listed the name as the synonym of Lithobotrys. This is not the designation of the type species.

\section{Botryopera triloba Ehrenberg group}

(Plate 11, Figures 27-29, 36-39; Plate 20, Figures 3, 4)

Lithomelissa boreale (Ehr.) Petrushevskaya, 1967, p. 83, pl. 48, fig. 1-4; ?1968, p. 1767, fig. 1, I, II

Lithomelissa sp. B Petrushevskaya, 1967, p. 82, fig. 47.

Trisulcus borealis (Ehr.) Petrushevskaya, 1971b, p. 145, pl. 74.

Eucephalic lobe looks as if it is half hidden in the thorax, because the additional parts of the cephalis are not separated from the thorax. This part of the shell is very complicated. Spines $L$ are asymmetrical toward MB. These features are characteristic for the whole genus.

The top of the cephalis is round. In typical forms the additional spines are few and weak, the pores are small and numerous (Plate 20, Figure 3). In Lithomelissa setosa Jörgensen (Plate 11, Figure 39), the spines are very numerous and rather strong. In some the specimens from Antarctic (Plate 11, Figures 27-29) pores are few and large. The species group is very variable in space and time and the specimens from the same sample usually are not equal, especially if viewed from various sides. The ratio of the breadth of the eucephalic lobe and the thorax seem to be the important indicator of the races of the speciesgroup.

Miocene-Recent. All geographical zones, but most numerous in the temperate waters. 
Botryopera deflandrei n. sp.

(Plate 11, Figures 30-32)

Lithomelissa sp. P, Petrushevskaya, ?1973, p. 244, no. 10, pl. 3, fig. 12. The ratio of the breadths of the eucephalic lobe and the thorax is about $1: 1.5$, the same as in $B$. triloba, gr. The shell dimensions and the pore arrangement are also nearly the same. The walls are thicker and smooth. The whole skeleton is less variable. The distinguishing characteristic is the outline of the upper part of the eucephalic lobe: it is elongated into a peak. This formation is known for Trisulcus sp. and for $T$. boldyrae (Petrushevskaya, 1971b, pl. 46, fig. 6-11). B. deflandrei is very similar to these two species, especially to the tropical Oligocene Trisulcus sp. (but $B$. deflandrei is larger). This apical peak is unconnected with the apical spine $A$, but it is possible that it represents the rudiment of the central position of the spine $A$ (known in Lithomelissa where the spine $A$ forms columella in the eucephalic lobe, and forms apical horn on the top of the shell, Petrushevskaya, 1971b, pl. 44,45$)$.

Antarctic Miocene.

The description is based on 26 specimens from Site 278 (Cores 1420). Holotype No. 63119 in the Marine Department. Species is named after the reknowned micropaleontologist George Deflandre.

\section{Botryopera (?) chlamida n. sp.}

(Plate 20, Figures 5, 6)

The walls are thick. The pores variable and numerous. The spongy layer envelops the main shell. This is the distinguishing character of the species. The shell is bigger but the shell outline is similar to $B$. triloba group: the cephalis of nearly the same width as the thorax. However, thorax (ellipsoidal or cylindrical) is somewhat broader than the cephalis. The arrangement of the outer spines $A, D, L$ and $V e r t$ typical for Botryopera. No horn on the top of the cephalis. The species may belong in the same genus with Antarctissa (?) capitata. B. (?) chlamida differs from $A$. (?) capitata by the longer and broader thorax, better developed outer spines $D, A, L$ and $V e r t$, and more pronounced spongy layer. B. (?) chlamida differs from Botryometra spongiosa $\mathrm{n} . \mathrm{sp}$. (Plate 13, Figure 11) in having a cephalis nearly the same size as the thorax. Also, in $B$. (?) chlamida the branches $a$ are arranged low (no higher than at $1 / 3$ of the spines $A$ ), while in the species mentioned these branches are highly arranged, nearly going in the upper walls of the cephalis. The most characteristic feature of Botryometra (?) spongiosa is the well-developed antecephalic lobe (of nearly the same type as in Cannobotyods), this lobe in $B$. (?) chlamida is small and confused (as it is characteristic for Botryopera and some other Dicyrtids) with the thorax. In the species mentioned the cephalis is well separated from the thorax. The author is not sure if this species and $B$. (?) chlamida are related. It is possible that their spongy layers represent only a convergent- or parallel-developed structure. $B$. (?) chlamida is very rare. The description is based on 3 specimens from $O b$ Stations 16 and 153 surface sediment. Holotype No. 63118 in Marine Department. Species name means "dressed" (in spongy layer).

\section{Botryopera oceanica (Ehrenberg) group}

(Plate 18, Figures 7, 10; Plate 19, Figures 4, 5)

Lithopera oceanica Ehrenberg, 1872, pl. 4, fig. 21; Petrushevskaya, 1967 , pl. 48 , fig. 7.

Lithomelissa hystrix Jörgensen, 1905, p. 135, pl. 16, fig. 85.

Very much the same as L. braevispicula Popofsky (Petrushevskaya, 1967 , p. 77, fig. 44) but the walls are more delicate and the pores are more numerous. In this characteristic (the walls are sometimes nearly spongy) B. oceanica is similar to Lithomelissa (?) capitata Popofsky. There also is a similarity in the shell construction and outline, but $B$. oceanica is smaller than $L$. (?) capitata. Very probably the two species belong in the same genus but their origin is obscure.

In Quaternary, Antarctic.

\section{Genus PSEUDODICTYOPHIMUS Petrushevskaya}

Pseudodictyophimus Petrushevskaya, 1971b, p. 91; Petrushevskaya and Kozlova, 1972, p. 534. Type species Dictyophimus gracilipes Bailey, 1856, fig. 8.

Very much the same as Ceratocyrtis, but with lateral feet.

\section{Pseudodictyophimus gracilipes (Bailey) group}

For synonymy see Petrushevskaya, 1971b, p. 93. Miocene-Recent.

\section{Genus LAMPROTRIPUS Haeckel}

Lamprotripus Haeckel, 1881, p. 432; 1887, p. 1199; non Campbell, 1954, but Petrushevskaya, 1971b, p. 95; Petrushevskaya and Kozlova, 1972, p. 534. Type species Lamprotripus squarrosus Haeckel, 1887, pl. 60, fig. 1 .

\section{Lamprotripus mawsoni (Riedel)}

(Plate 12, Figure 8)

Dictyophimus mawsoni Riedel, 1958, p. 234, pl. 3, fig. 6, 7.

Lamprotripus mawsoni (Riedel) Petrushevskaya and Kozlova, 1972, p. 534 , pl. 29 , fig. 15.

\section{Family Lophophaenidae Haeckel}

Lophophaenida Haeckel, 1881, p. 430; Campbell, 1954, p. 123; Petrushevskaya, ?1971, p. 989, group III; 1971b, p. 86, part.; Petrushevskaya and Kozlova, 1972, p. 534.

Two segments of nearly equal size. Cephalis with well-developed eucephalic lobe, much higher than the additional lobes which are not very well developed. The branches $a$ have a low arrangement. The cephalis with the "neck" (Figure 10, II, III).

It seems likely that different genera of the family descend from various genera of Lampromitrids: cephalis became narrower at the base and the "neck" arose. Thorax became reduced, but some Lophophaenids may have descended from the Paleozoic Archocyrtium and other forms, described by Deflandre, ?1973. It seems possible that Botryopera species listed above and Antarctissa denticulata, A. (?) robusta, Lithomelissa (?) capitata, and Dictyocephalus (?) equiceps belong in Lophophaenidae, not in Lampromitridae, but their ancestors are to be investigated.

\section{Genus ARACHNOCORALLIUM Haeckel}

Arachnocorallium Haeckel, 1887, p. 1265; Petrushevskaya, 1971b, p. 135. Type species Arachnocorys hexaptera Haeckel, 1887 (Hertwig, 1879 , pl. 8 , fig. $2 \mathrm{a})$.

\section{Arachnocorallium spp.}

(Plate 9, Figures 17-19)

Some specimens (Plate 9, Figures 17, 18) are very similar to $A$. calvata (Petrushevskaya, 1971b, fig. 70), but they are a bit bigger and the surface is rough. The others (Plate 9, Figure 19) have more pores and the thorax is better developed. The latter are very numerous in some samples of Site 278 through the entire Miocene. They seem to be good indicators of the surplus of warmer waters in this Antarctic region.

\section{Genus LITHOMELISSA Ehrenberg}

Lithomelissa Ehrenberg, 1847, p. 54; non Haeckel, 1881, p. 431; 1887, p. 1203; non Campbell, 1954, p. 122.

Acromelissa Haeckel, but Petrushevskaya, 1971b, p. 90; Haeckel, 1881 , p. 431 , 1887 , p. 1203 . Type species L. microptera Ehrenberg, 1854 , pl. 36 , fig. 2 .

Campbell designated L. tartari Ehrenberg, 1854, as the type species of Lithomelissa, but this species was not illustrated by Ehrenberg and it is impossible to base the characteristic of the genus on the unknown species. If it is impossible to replace $L$. tartari by $L$. microptera in the. Commission on Zoological Nomenclature, the name Lithomelissa must be abandoned because the diagnosis of the genus cannot be stable. The type species for Acromelissa was not designated by Campbell because the mentioning of the genus name as the synonym is not the designation of the type species. The author proposes Lithomelissa microptera Ehrenberg to be the type species of Acromelissa Haeckel. This species was originally included in Acromelissa by Haeckel. This species was illustrated and it can easily be identified (Petrushevskaya, 1971b, pl. 44, fig. 6). If the Lithomelissa is without a reliable type species, the genus in question should be named Acromelissa.

Lithomelissa sp. aff. L. haeckeli Butschli

(Plate 9, Figures 24-26; Plate 24, Figure 2; Plate 44, Figure 3)

(?)Lithomelissa haeckeli Butschli, 1882, pl. 33, fig. 23; Petrushevskaya

1971 b, pl. 45 , fig. $2-5$.

Differs from the typical $L$. haeckeli by more pronounced "neck" of the cephalis, the latter being distinctly separated from the thorax. This 
is why the Leg 29 species may be better referred to some other species name.

Eocene-Oligocene. In the Antarctic some specimens of that species group occur in Miocene deposits.

\section{Suborder SPYRIDA Ehrenberg}

Spyridina Ehrenberg, 1847b, p. 53; Petrushevskaya, 1971a, p. 990; 1971b, p. 240; Petrushevskaya and Kozlova, 1972, p. 529.

Acanthodesmiidae Haeckel 1862, sensu Riedel, 1967, p. 296. Trissocyclidae Haeckel, 1881, sensu Goll, 1968.

Nassellarians with the bilocular cephalis no less than $50 \mu$ high. Cenozoic.

\section{Family TRIOSPYRIDIDAE Haeckel}

Triospyrida Haeckel, 1881, p. 441; 1887, p. 1025; Campbell, 1954, p. 112; Petrushevskaya, 1971a, p. 990; 1971b, p. 243; Petrushevskaya and Kozlova, 1972, p. 529.

The same skeleton differentiation as in Cyrtids (differentiation along the axis parallel to the apical spine $A$ ) is easily seen in the cephalis construction and in the thorax, feet, galea, etc. Cephalis more or less complicated.

Paleocene-Recent.

\section{Genus DESMOSPYRIS Haeckel}

Desmospyris Haeckel, 1881, p. 443; 1887, p. 1089; Campbell, 1954, p. 116; Petrushevskaya, 1971b, p. 248; Petrushevskaya and Kozlova, 1972, p. 531. Type species Desmospyris mammilata Haeckel, 1887, pl. 83 , fig. 14 .

Two segments: the cephalis and the thorax; thorax usually narrower than cephalis; no real feet and generally no horns.

Paleocene-Recent.

Desmospyris rhodospyroides n. sp.

(Plate 10, Figures 27-29, 31, 32)

(?)Rhodospyris sp. A Petrushevskaya and Kozlova, 1972, p. 531, pl. 38, fig. 11.

Sagittal ring is enclosed in the cephalis and the pores are smaller and more numerous than in Desmospyris sp. A (Petrushevskaya and Kozlova, 1972, pl. 38, fig. 12,13). No less than 9-10 pores near the ring (on one lobe of the cephalis). Pores irregular, polygonal; thick walls. Thorax and cephalis are nearly of same width; thorax may be even a bit broader, untypical for the genus. The shell mouth is constricted, may be closed, and without any special tooth.

Antarctic Miocene.

Description is based on 14 specimens from Site 278 (Core 12). Holotype No. 63121 in the collection of the Marine Hydrobiology Department.

\section{Desmospyris (?) haysi n. sp.}

(Plate 8, Figures 3, 4; Plate 27, Figures 4-6)

Triceraspyris antarctica (Haecker) sens. Petrushevskaya, 1967, pl. 37, fig. 5, 6, part.

Tholospyridium sp. Petrushevskaya, 1973b, p. 1044, no. 5, pl. 3, fig. 20, 21.

No less than about 20 pores near the ring (on one lobe of the cephalis). Pores small, irregular; walls, smooth and rather thin. Thorax is shorter and narrower than the cephalis. The shell mouth indefinite. Sometimes feet (variable in size and number) can be seen.

Antarctic Miocene-Pliocene.

Description is based on five specimens from Sample 281-6, CC. Holotype No. 63117 in the collection of Marine Hydrobiology Department. Species is named after Hays who was the first to investigate Antarctic radiolarian stratigraphy.

In the Antarctic Miocene a number of species are similar to the species in question (Plate 8, Figures 2, 5). Fewer pores than in D. (?) haysi and the thorax is undeveloped. They may be included into Tholospyris or even in Platybursa. The author is not sure $D$. (?) haysi is related to these species.

Desmospyris spongiosa Hays

(Plate 10, Figures 33, 34; Plate 27, Figure 8)

Desmospyris spongiosa Hays, 1965, p. 173, pl. 2, fig. 1; Petrushevskaya, 1973b, pl. 3, fig. 22.
Very much the same as $D$. rhodospyroides, but the walls are "spongy", and from the surface rise small papillae, connected by the threads and pores of the main wall as if fastened or subdivided. The walls are thicker, the number of the pores in the main walls may be a bit more than in $D$. rhodospyroides.

Antarctic Miocene-Pliocene.

\section{Genus TRICERASPYRIS Haeckel}

(?)Triceraspyris Haeckel, 1881, p. 441; 1887, p. 1029; non Campbell, 1954 , p. 112 , but Petrushevskaya, 1971 b, p. 249. Type species Triceraspyris giraffa Haeckel, 1887, pl. 84, fig. 11.

Dendrospyris Haeckel, 1881 , p. 441; 1887, p. 1038; Campbell, 1954, p. 112; Goll, 1968, p. 1417; Petrushevskaya and Kozlova, 1972, p. 532. Type species Ceratospyris stylophaena Ehrenberg, 1873; 1875, pl. 20, fig. 10.

Giraffospyris Haeckel, 1881, p. 442; 1887, p. 1056; Campbell, 1954, p. 114; Goll, 1969, p. 329, part. Type species Ceratospyris heptaceros Ehrenberg, 1873; 1875, pl. 20, fig. 2.

Aegospyris Haeckel, 1881, p. 442; 1887, p. 1053; non Campbell, 1954, p. 112; but Riedel, 1959b, p. 6. Type species Aegospyris aegoceras Haeckel, 1887, pl. 95, fig. 10.

Triospyrium Haeckel, 1887, p. 1030; Campbell, 1954, p. 112. Type species Ceratospyris furcata Ehrenberg, 1873; 1875, pl. 20, fig. 8.

Thick-walled cephalis. Large pores situated symmetrically on both sides of the tagittal ring. Six feet are directed downwards, two stronger than the others. Several horns on the cephalis.

\section{Triceraspyris antarctica (Haecker) group} (Plate 8, Figure 1)

Phormospyris antarctica Haeckel, 1907, p. 124, fig. 9.

Triceraspyris antarctica Haecker, 1908, p. 445, pl. 84, fig. 586; Riedel, 1958 , p. 230 , pl. 2, fig. 6, 7, fig. 3; Petrushevskaya, 1964, p. 1121, fig. $1 ; 1967$, p. 65 , pl. 37 , fig. $1-3$.

Tripospyris bicornis Popofsky, 1908, p. 269, pl. 30, fig. 6.

Tripospyris biloculata Popofsky 1908, p. 269, pl. 30, fig. 7.

Besides typical forms with thin-walled, smooth, one-segmented shell with rounded pores of medium size and three weak feet, there are forms with much stronger feet, larger polygonal pores, and thick walls. In some specimens the feet are included into incomplete walls of the second segment, the thorax. Perhaps other forms can also be observed. They are to be investigated and described as species.

Miocene-Recent.

\section{ACKNOWLEDGMENTS}

The author expresses her gratitude to Yv. S. Badashov, N. E. Mikao, G. S. Leibevich, and P. I. Genkin, of the electron microscope facility of the Institute of Zoology. All worked with and provided help to the author in obtaining the photographs. The author is most grateful to A. Lisitzen (Institute of Oceanology, Academy of Sciences, USSR) and to J. Hays (Lamont-Doherty Geological Observatory) for providing samples from the R/V Ob, and Eltanin cruises in the Antarctic and sub-Antarctic. James P. Kennett, co-chief scientist of DSDP Leg 29, made samples available from this cruise. J. Westberg did the shipboard processing of the samples.

Part of the text was translated into English by Edith Roden, with retyping by $M$. A. Hanger. The author expresses her gratitude to all these individuals and especially to A. P. Andriashev and A. A. Strelkov for their valuable advice and consultations.

\section{REFERENCES}

Bailey, J. W., 1856. Notice of microscopic forms found in the soundings of the sea of Kamtschatka: Am. J. Sci. Arts. ser. 2, XXII, p. 1.

Bandy, O. L., Casey, R. E., and Wright, R. C., 1971. Late Neogene planktonic zonation, magnetic reversals and radiometric dates, Antarctic to the Tropics: Antarctic Res. Ser., Biol. Antarctic Seas, IV, Am. Geophys. Union, v. 15, Washington, p. 1-26. 
Burma, B. H., 1959. On the status of Theocampe Haeckel, and certain similar genera: Micropaleontology, v. 5, (3).

Bütschli, O., 1882. Beitrage zur Kenntnis der Radiolarienskelette, insbesondere der Cyrtida: Z. Wiss. Zool., v. 36, p. 485-540.

Campbell, A. S., 1954. Radiolaria. In: Treatise on invertebrate paleontology: Moore, R. C., (Ed.) Lawrence, Kansas (Geol. Soc. Am., Univ. Kansas Press) pt. D, Protista 3, p. 11-163.

Campbell, A. S. and Clark, B. L., 1944a. Miocene radiolarian faunas from Southern California: Geol. Soc. Am. Spec. Paper 51, p. i-vii, 1-76.

1944b. Radiolaria from Upper Cretaceous of middle California: Geol. Soc. Am. Spec. Paper 57, p. i-viii, 161.

Carnevale, P., 1908. Radiolarie e Silicoflagellati di Bergonzano (Reggio Emilia): Mem. R. Veneto Sci. Lett., v. 28 (3), p. $1-46$.

Casey, R. E., 1971. Radiolarians as indicators of past and present water masses. In The micropaleontology of oceans: Funnell, B. M. and Riedel, W. R., (Eds.) Cambridge (Cambridge Univ. Press), p. 331.

Clark, B. L. and Campbell, A. S., 1942. Eocene radiolarian faunas from the Mt. Diablo area, California: Geol. Soc. Am. Spec. Paper 39.

1945. Radiolaria from the Kreyenhagen Formation near Los Banos, California: Geol. Soc. Am. Mem. 10, p. ivii, $1-66$.

Cleve, P. T., 1899. Plankton collected by the Swedish Expedition to Spitzbergen in 1898: K. Svenska Vetensk, Akad. Handl. v. 32 (3), p. 1.

Deflandre, G., 1953. Radiolaries fossiles. In traité de zoologie: Grassé, P.-P., (Ed.), Paris (Masson), v. 1, pt. 2, p. 389-436.

1972. Nothotripodiscinus nov. gen. Radiolaire (?) aberrant á skelette creux, d'une vase du Pacific tropical, type d'une famile nouvelle, Nothotripodiscidae, de position systematic incetaine: C. R. Acad. Sci. Paris, v. 275 D, p. 229-232.

Dogel, V. A. and Reshetnyak, V. V., 1952. Materialy po radiolariyam severo-zapadnoi chasti Tikhogo okeana: Issled. dalnevostoch. morei SSSR, v. III.

Dreyer, F., 1889. Morphologische Radiolarienstudien. 1. Die Pylombildungen in vergleichend-anatomischer und entwicklungsgeschichtlicher Beziehung bei Radiolarien und bei Protisten überhaupt, nebst System und Beschreibung neuer und der bis jetzt bekannten pylomatischen Spumellarien, Jena: Z. Naturw., v. 23, (n. ser. v. 16), p. 1138.

Dumitrica, P., 1968. Consideratii micropaleontologice asupra orizontului argilos cu radiolari din tortonianul regiunii carpatice: Stud. Cerc. Geol. Geofiz. Geogr., Ser. Geol. Bucuresti, v. 13 (1), p. 227.

Dumitrica, P., 1970. Cryptocephalic and cryptothoracic Nassellaria in some Mesozoic deposits of Romania: Romanian Geol. Geophys. Geogr. Ser. Geol. Rev., v. 14 (1).

1972. Siliceous microfossils, Leg 13 of the Deep Sea Drilling Project, In Ryan, W. B. F., Hsü, K. H., et al., Initial Reports of the Deep Sea Drilling Project, Volume 13, Washington, (U.S. Government Printing Office), p. 829-969.

Ehrenberg, C. G., 1838. Uber die bildung der kreidefelsen und des kreidemergels durch unsichtbare organismen: Abhandl. Preuss. Akad. Wiss.

1844a. Uber 2 neue lager von gebirgsmassen aus infusorien als meeres-absatz in Nord-Amerika und eine vergleichung derselben mit den organischen kreidegebilden in Europa und Afrika: Monatsber. Kgl. Preuss. Akad. Wiss. Berlin, p. 57-97. 1844b. Einige vorlaufige resultate seiner Untersuchungen der ihm von der Südpolreise des Capitain Ross, so wie von den Herren Schayer und Darwin zugekommenen materialien uber das verhalten des kleinsten Lebens in den oceanen und den grössten bisher zugänglichen tiefen des weltmeeres: Monatsber. $\mathrm{Kgl}$. Preuss. Akad. Wiss. Berlin, p. 182-207.

1847a. Uber eine halibiolithische, von Herrn R. Schomburgk entdeckte, vorherrschend aus mikroskopischen Polycystinen gebildete, Gebirgsmasse von Barbados: Monatsber. Kgl. Preuss. Akad. Wiss. Berlin, p. 382-385.

$1847 \mathrm{~b}$. Uber die mikroskopischen kieselschaligen Polycystinen als mächtige Gebirgsmasse von Barbados und über das Verhaltnis der aus mehr als 300 neuen Arten bestehenden ganz eigenthümlichen Formengruppe jener Felsmasse zu den lebenden Thieren und zur Kreidebildung. Eine neue Anregung zur Erforschung des Erdlebens: Monatsber. Kgl. Preuss. Akad. Wiss. Berlin, p. 40-60. 1854. Mikrogeologie: Leipzig (Fortsetzung) (1856).

1858. Kurze characteristik der 9 neuen genera und der 105 neuen species des ägäischen meeres und des tiefgrundes des mittelmeeres: Monatsberg. Kgl. Preuss. Akad. Wiss. Berlin.

1860a. Uber die organischen und unorganischen Mischungsverhaltnisse des Meeresgrundes in 19,800 Fuss Tiefe nach Lieut. Brookes Messung: Monatsberg. Kgl. Preuss. Akad. Wiss. Berlin, p.

1860b. Uber den Tiefgrund des stillen Ozeans zwischen Californien und den Sandwich-Inseln aus bis 15,600 Fuss Tiefe nach Lieut. Brookes: Monatsber. Kgl. Preuss. Akad. Wiss. Berlin, p. 819-833.

1862. Uber die Tiefgrud-Verhaltnisse des Oceans am Eingange der Davisstrasse und bei Island: Monatsber. Kgl. Preuss. Akad. Wiss. Berlin, p. 1-275.

1872a. Mikrogeologischen Studien als Zusammenfassung seiner Beobachtungen des kleinsten Lebens der Meeres-Tiefgrunde aller Zonen und dessen geologischen Einfluss: Monatsber. Kgl. Preuss. Akad. Wiss. Berlin, p. 265-322.

1872b. Mikrogeologischen Studien über das kleinste Leben der Meeres-Tiefgrunde aller Zonen und dessen geologischen Einfluss: Abhandl. Kgl. Akad. Wiss. Berlin, p. 131-399.

1873. Grössere Felsproben des PolycystinenMergens von Barbados mit weiteren Erlauterungen: Monatsber. Kgl. Preuss. Akad. Wiss. Berlin, p. 213-263. 1875. Fortsetzund der mikrogeologischen Studien als Gesammtubersicht der mikroskopischen Paläontologie gleichartig analysirter Gebirgsarten der Erde, mit specieller Rücksicht auf den Polycystinen-Mergel von Barbados: Abhandl. Kgl. Preuss. Akad. Wiss. Berlin, p. 1-226.

Foreman, H. P., 1966. Two Cretaceous radiolarian genera: Micropaleontology, v. 12 (3), p. 355-359.

1968. Upper Maestrichtian Radiolaria of California: Spec. Papers Palaeontol. (London Palaeontol. Assoc.), no. 3 , p. $1-82$.

1973. Radiolaria of Leg 10 with systematics and ranges for the families Amphypindacidae, Artostrobiidae, and Theoperidae. In Worzel, J. L., Bryant, W., et al., Initial Reports of the Deep Sea Drilling Project, Volume 10, Washington (U.S. Government Printing Office), p. 407474.

Frezzel, D. L. and Middoor, E. S., 1951. Paleocene Radiolaria from southeastern Missouri: Univ. Missouri Sch. Mines Met. Bull., Tech. Ser. 77, p. 1.

Goll, R. M., 1968. Classification and phylogeny of the Cenozoic Trissocyclidar (Radiolaria) in the Pacific and 
Caribbean Basins. Part I: J. Paleontol., v. 42 (6), p. 1409. , 1969. Classification and phylogeny of the Cenozoic Trissocyclidae (Radiolaria) in the Pacific and Caribbean Basins. Part II: J. Paleontol., v. 43 (2) p. 322.

Haeckel, E., 1860. Abbildungen und diagnosen neuer Gattungen und Arten von lebenden Radiolarien des Mittelmeeres: Monatsber. Kgl. Preuss. Akad. Wiss. Berlin, p. 835-845.

1862. Die Radiolarien (Rhizopoda Radiaria). Eine monographie: Berlin (Reimer), p. 1-572.

1881. Prodromus Systematic Radiolarium. Entwurf eines Radiolarien-Systems auf Grund von Studien der Challenger-Radiolarien, Jena: Z. Naturw., v. 15 (n. ser. v. 8 , no. 3), p. 418-472.

1887. Report on the Radiolaria collected by H.M.S. Challenger during the years 1873-1876: Rept. Sci. Res. Voy. Challenger. 1873-1876, Edinburgh, Zool., t. XVIII, pt. I, II.

Haecker, V., 1908. Tiefsee-Radiolarien: Wiss. Ergeb. Deutsch. Tiefss-Exped. Valdivia, v. 14, p. 477-706.

Harting, P., 1863. Bijdrage tot de kennis der mikroskopische faune en flora van de Banda-Zee: Verhandl. Koninkl. Akad. Wetensch. Amsterdam, v. 10, p. 1-34.

Hays, J. D., 1965. Radiolaria and Late Tertiary and Quaternary history of Antarctic seas: Antarctic Res. Ser., Biol. Antarctic Seas, vol. 2, Am. Geophys. Union, v. 5, p. 125184.

1970. Stratigraphy and evolutionary trends of Radiolaria in north Pacific deep-sea sediments: Geol. Soc. Am. Mem. 126, p. 1-185.

Hays, J., Saito, T., Opdyke, N. D., and Burckle, L. H., 1969. Pliocene-Pleistocene sediments of the equatorial Pacific: their paleomagnetic biostratigraphic and climatic record: Geol. Soc. Am. Bull., v. 80 (8), p. 1481-1514.

Hertwig, R., 1879. Der organismus der Radiolarien: Jena (G. Fischer), p. 1-149.

Hollande, A. and Enjumet, M., 1960. Cytologie, évolution et systematique des Sphaeroîdés (Radiolaires). Arch. Mus. Natl. Hist. Nat. Paris, ser. 7, v. 7, p. 1-134.

Hulsemann, K., 1963. Radiolaria in plankton from the Arctic Drifting Stations T-3, including the description of three new species: Arctic Inst. N. Am., Tech. Paper No. 13, p. 152.

Jörgensen, E., 1905. The protist plankton and the diatoms in bottom samples: Bergens Mus. Skr., p. 49-151, 195-225.

Kling, S. A., 1971. Radiolaria: Leg 6 of the Deep Sea Drilling Project. In Fisher, A. G., Heezen, B. C., et al., Initial Reports of the Deep Sea Drilling Project, Volume 6, Washington (U.S. Government Printing Office), p. 10691118.

1973. Radiolaria from the eastern North Pacific, Deep Sea Drilling Project, Leg 18. In Kulm, L. D., von Huene, R., et al., Initial Reports of the Deep Sea Drilling Project, Volume 18, Washington (U.S. Government Printing Office) p. 617-671.

Kozlova, G. E., 1967a. Tipy stroeniya radiolarii iz sem. Porodiscidae: Zool. Zhur., v. 46, p. 8.

1967b. O filogeneticheskoi svyazi podotryadov Discoidea i Larcoidea (Radiolaria, Spumellaria): Zool Zhur., v. 46, p. 9.

Kozlova, G. E., and Gorbovets, A. N., 1966. Radiolarii verkhnemelovykh i verkhne-eozenovykh otlozhenii Zapadno-Sibirskoi nizmennosti, nedra: Vses. Neft. Nauchno-Issled. Geol., Razu Inst. no. 248, p. 159.

Kruglikova, S. B., 1969. Radiolarii v kolonke St. 4066 (severnaya chast Tikhogo okeana). V. sb. Osnovnye problemy mikropaleontologii i organo-gennogo osadkonakopleniya v okeanakh i moryarch. M., Moscow (Nauka), p. 48-72.
Ling, H. Y., 1973. Radiolaria: Leg 19 of the Deep Sea Drilling Project. In Creager, J. S., Scholl, D. W., et al., Initial Reports of the Deep Sea Drilling Project, Volume 19: Washington (U.S. Government Printing Office), p. 777797.

Lipman, R. Kh., 1960. Su-class Radiolaria. In Stratigrafiya i fauna melovykh otlozhenii zapadnosibirskoi nizmennosti. (Stratigraphy and fauna of the Cretaceous deposits in the western Siberian lowlands): Glazunova, A. E. (Ed.), Tr. VSEGEI, N. Ser., v. 29 , p. 124.

Loeblich, A. R., Jr. and Tappan, H., 1961. Remarks on the systematics of the Sarcodina (Protozoa), renamed homonyms and new and validated genera: Biol. Soc. Washington Proc., v. 74, p. 213-214.

Martin, G. C., 1904. Radiolaria: Maryland Geol. Surv., Gen. Ser., Baltimore., p. 447-459.

Nakaseko, K., 1963. Neogene Cyrtoidea (Radiolaria) from the Isozaki Formation in Ibaraki Prefecture, Japan: Osaka Univ. Sci. Rept., v. 12 (2), p. 165-198.

1964. Liosphaeridae and Collosphaeridae (Radiolaria) from the sediments of the Japan Trench: Osaka Univ. Sci. Rept. v. 13 (1), p. 39-57.

1970. Biostratigraphy. In Initial Reports of the Deep Sea Drilling Project, Volume 2: Washington, (U.S. Government Printing Office), p. 391-411.

1971a. On the Spongoplegma antarcticum Haeckel: Osaka Univ. Sci. Rept. v. 20(2), p. 51-57. 1971b. On some species of the genus Theocosphaera from the Neogene Formations, Japan: Osaka Univ. Sci. Rept. v. 20(2), p. 59-66.

Nakaseko, K. and Nishimura, A., 1971. A new species from the Neogene Formation, Japan: Osaka Univ. Sci. Rept., v. 20(2), p. 67-71.

Nakaseko, K. and Suchano, K., 1970. On Radiolaria from the sediment of the Japan Sea (depth $1600 \mathrm{~m}$ ), Osaka Univ. Sci. Rept. no. 5: p. 38-42 (In Japanese).

1973. Neogene Radiolarian zonation in Japan, Osaka Univ. Sci. Rept. no. 8, p. 23-33.

Nigrini, C., 1967. Radiolaria in pelagic sediments from the Indian and Atlantic Oceans: Scripps Inst. Oceanogr. Bull., 11. 1971. Radiolarian zones in the Quaternary of the equatorial Pacific Ocean. In Funnell, B. M. and Riedel, W. $\mathrm{R}$. The micropaleontology of the ocean: Cambridge (Cambridge Univ. Press), p. 443-461.

Parona, C. F., 1890. Radiolarie nei noduli selciosi del calcare giurese di Cittiglio presso Laveno: Soc. Geol. Italy Boll. v. 9, pt. 1, p. 1-46.

Pessagno, E. A., 1969a. The Neosciadiocapsidae, a new family of Upper Cretaceous Radiolaria: Am. Paleontol. Bull., v. $56(253)$.

1969b. Mesozoic planktonic foraminifera and Radiolaria. In Initial Reports of the Deep Sea Drilling Project, Volume I: Washington, D.C. (U.S. Government Printing Office).

1971. Jurassic and Cretaceous Hagiastridae from Black-Bahama Basin (Site 5A JOIDES) and the Great VAlley Sequence, California Coast Ranges: Am. Paleontol. Bull., v. 60(264), p. 1-80.

1972. Cretaceous Radiolaria. Parts I, II: Am. Paleontol., Bull., v. 61(270), 269-314. 1973. Upper Cretaceous Spumellariina from the Great Valley Sequence, California Coast Ranges: Am. Paleontol., Bull., v. 63(276), p. 49-102.

Petrushevskaya, M. G., 1962. Znachenie rosta skeleta radiolyarii dlya ikh sistematiki. Zool. Zhur. v. XII, p. 3, p. 331-341. 
1965. Osobennosti konstruktsii skeleta radiolarii Botryoidae (otryad Nassellaria): Tr. Zool. In-ta An SSSR, t. XXXV.

1967. Radiolarii otryadov Spumellaria i Nassellaria Antarkticheskoi oblasti (po materialam Sovetsko, Antarkticheskoi ekspeditsii): Issled. Fauny morei, t. IV (XII). (Resultaty Biol. Issled. Sovetskoi Antarktic. Eksped. [19501958], vyp. 3, p. 5-186.)

1968a. Gomologii v skeletakh radiolarii Nassellaria. 1. Osnovnye dugi v semeistve Cyrtoidae. Zool. Zhur. v. 47, vyp. 9.

1968b. Gomologii v skeletakh radiolarii Nassellaria. 2. Osnovnye dugi slozhnoustroennykh tsefalisov Cyrtoidae i Botryoidae. Zool. Zhur. v. 47, vyp. 12.

1969a. Raspredelenie skeletov radiolarii v osadkakh severnoi Atlantiki: Sb. "Drevnie i sovremennye radiolarii," Izd. Lvovsk. Gos un-ta, Lvov.

, 1969b. Spumelline and Nasselline Radiolarians in bottom sediments as water-masses indicators. In Micropaleontology and organogenous sedimentation in the oceans: Moscow (Nauka), p. 127-150.

1970. Prodolzhitelnost zhizni vidov radiolarii Otchetnaya nauchnaya sessiya: Zool. Inst. AN SSSR, Leningrad. Str. 6-7.

1971a. On the natural system of Polycystine Radiolaria: Plankt. Conf. Second, Rome 1970 Proc., v. p. 1971b. Radiolarii Nassellaria v planktone Mirovogo Okeana: Issled. Fauny morei, Leningrad. 1971c. Vudelenie stratigraphicheskich zones chetwetichnuch i verchnetretichnych otlojenyi metodom radiolarievogo analysa. In Drevnii radiolarii Srednei Asii, Duchanbe, p. 108-119.

1972a. Biostratigraphy of deep-sea Quaternary sediments on the radiolarian data: Okeanologia, v. 12(1), p. 71-86.

$1972 \mathrm{~b}$. Some aspects of paleogeography based on the radiolarian analysis of the deep-sea bottom sediments: Okeanologia, v. 12(4), p. 640-653.

1973a. Evolution of the skeleton in the radiolarian nassellalarian phylogeny: Internatl. Cong. Protozoo. Fourth, Clairmont-Ferrane, Proc.

1973b. Radiolarii v donnych otlojeniach ujnogo poloucharia: Okeanologia, v. 6, p. 1041-1051.

Petrushevskaya, M. and Kozlova, G., 1972. Radiolaria: Leg 14, Deep Sea Drilling Project. In Hayes, D. E., Initial Reports of the Deep Sea Drilling Project, Volume 14: Washington, (U.S. Government Printing Office), p. 459648.

Petrushevskaya, M. and Linkova, T. I., 1972. K voprosou o sviasi radiolarievych i paleomagnitnych zonach $\mathrm{v}$ donnych osadkach Indiiskogo okeana. Isvest. Akad. Nauk SSSR, Ser. Geol. no. 7, p. 18-23.

Popofsky, A., 1908. Die Radiolarien der Antarktis: Deutsche Sudpolar Exped., 1901-1903, Berlin, v. 10, zool. v. 2(3), p. 183-305.

1913. Die Nassellarien des Warmwassergebietes: Deutsche Sudpolar Exped., 1901-1903, Berlin, v. 14, zool. v. $6(11)$.
Principi, P., 1909. Contributo allo studio dei Radiolarii Miocenici Italiani: Soc. Geol. Italy Boll., v. 28, p. 1-22.

Riedel, W. R., 1953. Mesozoic and late Tertiary Radiolaria of Rotti: J. Paleontol., v. 27(6), p. 808-813. 1958. Radiolaria in Antarctic sediment. B.A.N.Z. Antarctic Res. Exped. Rept., ser. B, v. 6(10), p. 217-255. 1959a. Oligocene and lower Miocene Radiolaria in tropical Pacific sediments: Micropaleontology, v. 5(3), p. 285-302.

1959b. Preliminary draft of a petition to be submitted to the International Commission on Zoological Nomenclature: Scripps Institution of Oceanogr., La Jolla, Calif.

1967a. Some new families of Radiolaria: Geol. Soc. London Proc., No. 1640.

1967b. Class Actinopoda. In The fossil record: London (Geol. Soc. London).

1973. Cenozoic planktonic micropaleontology and biostratigraphy. In Annual Review of Earth and Planetary Sciences, v. 1, p. 241-268.

Riedel, W. R., Bramlette, M. N., and Parker, F. L., 1963. "Pliocene-Pleistocene" boundary in deep sea sediments: Science, v. 140, p. 1238.

Riedel, W. R. and Sanfilippo, A., 1970. Radiolaria. In Initial Reports of the Deep Sea Drilling Project, Volume 4: Washington (U.S. Government Printing Office), p. 503575 .

1971. Radiolaria. In Initial Reports of the Deep Sea Drilling Project, Volume 7: Washington (U.S. Government Printing Office), p. 1529-1672.

Rust, D., 1885. Beiträge zur kenntmiss der fossilen Radiolarien aus Gersteinen des Jura: Palaeontographica, v. 31(3) p. 273.

Sanfilippo, A. and Riedel, W. R., 1970. Post-Eocene “closed theoperid" radiolarians: Micropaleontology, v. 16(4), p. 446-462.

1973. Cenozoic Radiolaria (exclusive of Theoperids, Artostrobiids and Amphypyndacids) from the Gulf of Mexico, Deep-Sea Drilling Project, Leg 10. In Worzel, J. L., Bryant, W., et al., Initial Reports of the Deep Sea Drilling Project, Volume 10: Washington (U.S. Government Printing Office), p. 475-611.

Sanfilippo, A., et al., in press.

Schewiakoff, W., 1926. Die Acantharia des Golfes von Neapol: Mon. 37, Flora und Fauna del Golfo di Napoli (Rome), p. 1-755.

Stöhr, E., 1880. Die Radiolarienfauna der Tripoli von Grotte, Provinz Girgenti in Sicilien: Palaeontographica, v. 26 (ser. 3 , v. 2), p. 69-124.

Strelkov, A. A., Khabakov, A. V., and Lipman, R. K., 1959. Radiolarii: V. Kn. “Osnovy paleontologii," t. 1, Izd. AN SSSR, M.

Tregouboff, G., 1953. Classe des heliozoaires. In Traite de zoologie: Grassé, P.-P. (Ed.) Paris (Masson), v. 1, pt. 2, p. 437-489.

Vinassa de Regny, P. E., 1900. Radiolari Miocenici Italiani: Roy. Accad. Sci. Bologna Mem., ser. 5, v. 8, p. 565-595.

Zittel, K., 1876. Uber fossile Radiolarien der oberen Kreide: Z. Deutsch. Geol. Ges. 28. 



\section{PLATE 1}

Figures 1-9, 11-16, $\times 200$; Figure 10, $\times 100$

Figures 1, 2 Thecosphaerella ? ptomatus Sanfilippo and Riedel.

1. 29-280A-3-4.

2. $278-28-5$.

Figures 3, 4 Cenosphaera cristata Haeckel group.

3. $29-278-12-2$.

4. $29-278-12-1$.

Figure $5 \quad$ Haliomma sp. aff. H. aequorea Ehrenberg. 29-278$2-1$.

Figures 6-8 Cenosphaera ? megachile Clark and Campbell

6. 29-278-12-3.

7. $29-278-32-4$.

8. $29-278-32-5$.

Figure 9 Stomatosphaera ? haackei (Dreyer) group. 29-27828-4

Figures 10, 11 Haliommoidea gen. sp. indet.

10. 29-280A-6, CC.

11. $29-280 \mathrm{~A}-7-2$.

Figures 12, 13 Cenosphaera ? oceanica Clark and Campbell.

12. 29-280A-6, CC.

13. $29-278-32-5$

Figures 14, 15 Periphaena dupla (?) group. 29-281-16-4.

Figure 16 Heliodiscus sp. A. 29-278-12-1. 
CENOZOIC RADIOLARIANS OF THE ANTARCTIC

Plate 1

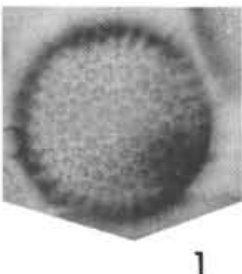

1

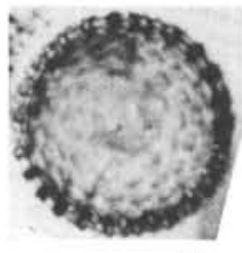

5

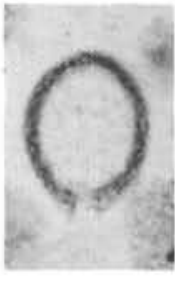

9
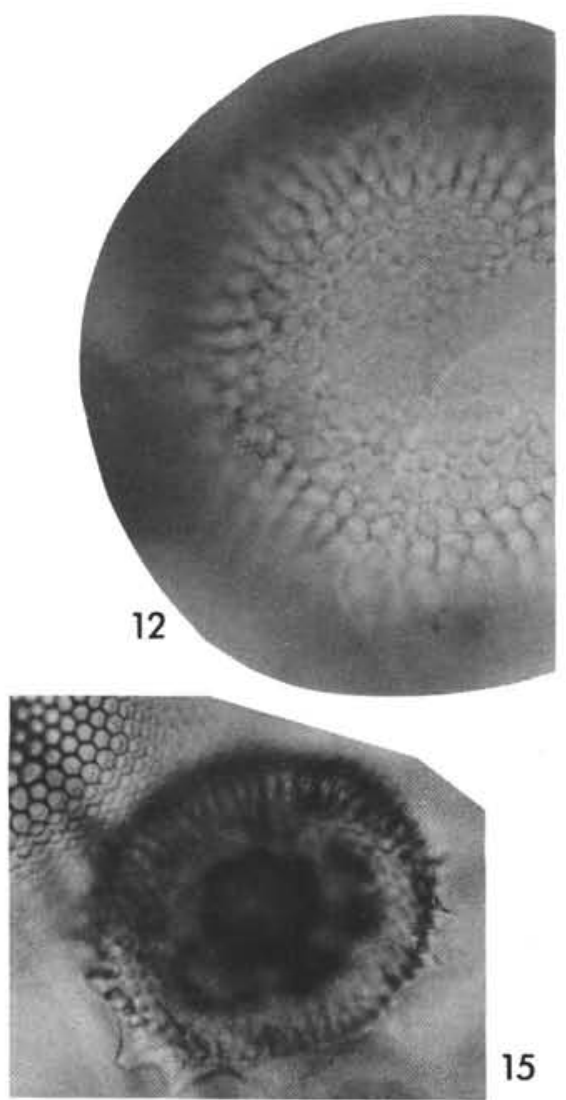

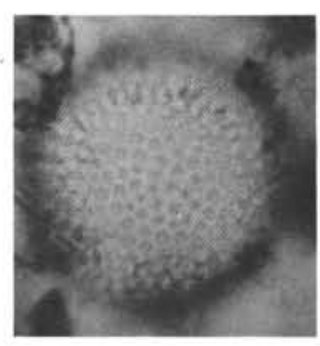

2
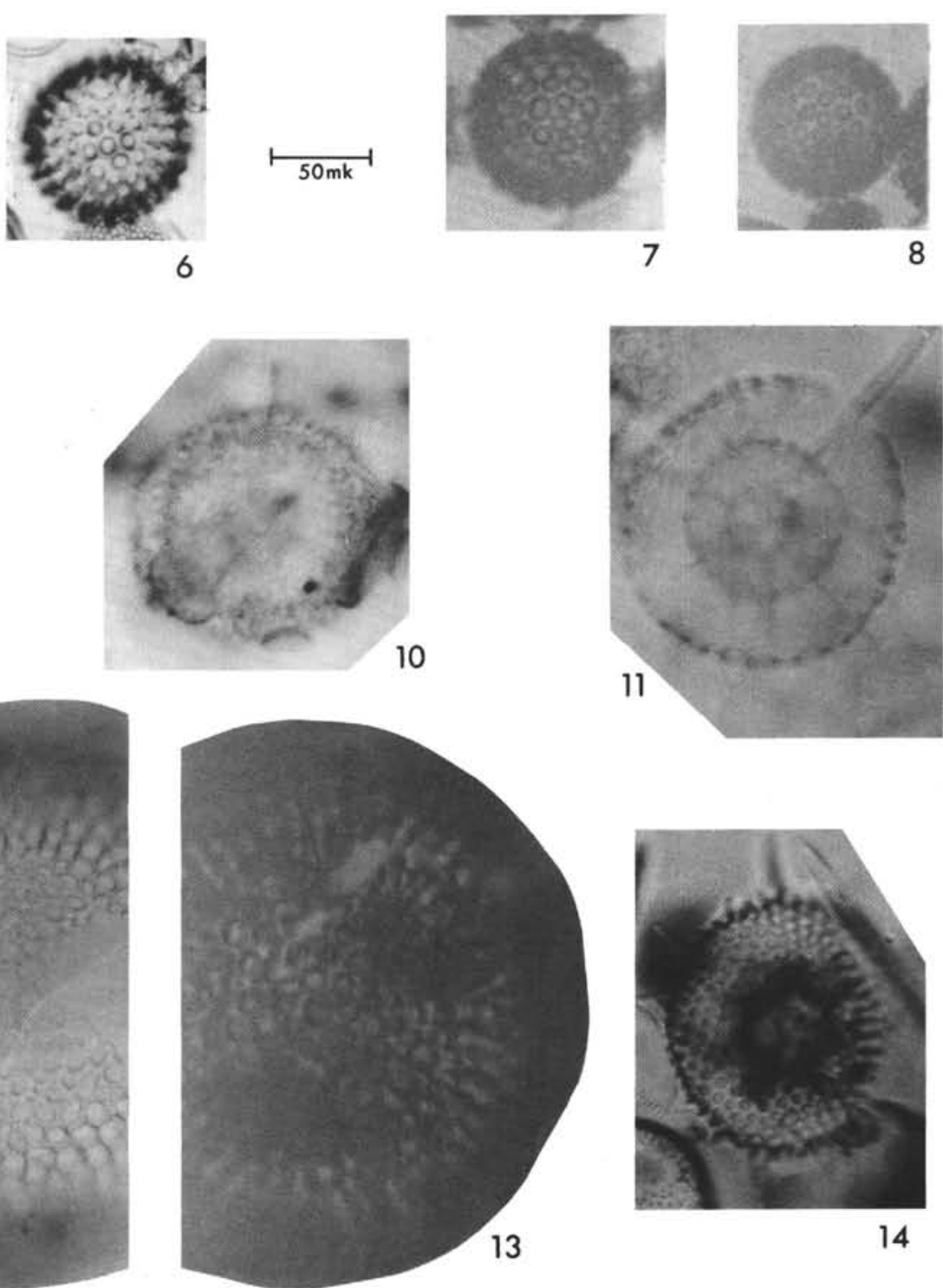


\section{PLATE 2 \\ All figures $\times 200$}

Figures 1, 2 Hexacromyum rara (Carnevale) group.

1. 29-278-14-1.

2. $29-278-14-2$.

Figures 3-5 Hexacromyum sexaculeatum (Stöhr).

3, 4. 29-278-33-2.

5. $29-278-14-4$.

Figures 6-8 Actinomma medusa (Ehrenberg) group.

6. 29-278-32-5.

7, 8. 29-278-33-2.

Figure 9 Haliommoidea gen. sp. 29-278-31-4.

Figure 10 Actinomma medusa $\beta$ (Ehrenberg). 29-278-33-6.

Figure 11 Hexacromyum delicatulum (Dogel) group. 29-278$12-1$.

Figures 12, 13 Stylosphaera sp. C.

12. 29-278-12-3.

13. $29-278-12-1$.

Figure 14 Stylosphaera hispida Ehrenberg group. 29-278-121.

Figure 15 Actinomma beroes (Ehrenberg) group. 29-278-121.

Figure 16 Actinomma golownini, holotype. 29-278-12-2.

Figure 17 Amphisphaera dixyphos (Ehrenberg). 29-278-33-1.

Figures 18-20 Amphisphaera radiosa (Ehrenberg) group.

18. 29-278-31-3.

19. $29-278-32-5$.

20. $29-278-31-3$.

Figure 21 Amphisphaera santhaennae (Campbell and Clark). 29-278-12-1.

Figure 22 Axoprunum liostylum (Ehrenberg) group. 29-28116-4. 


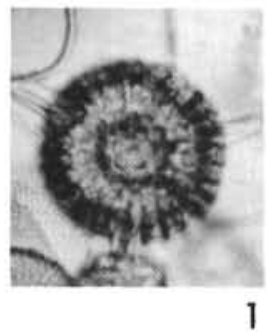

PLATE 2
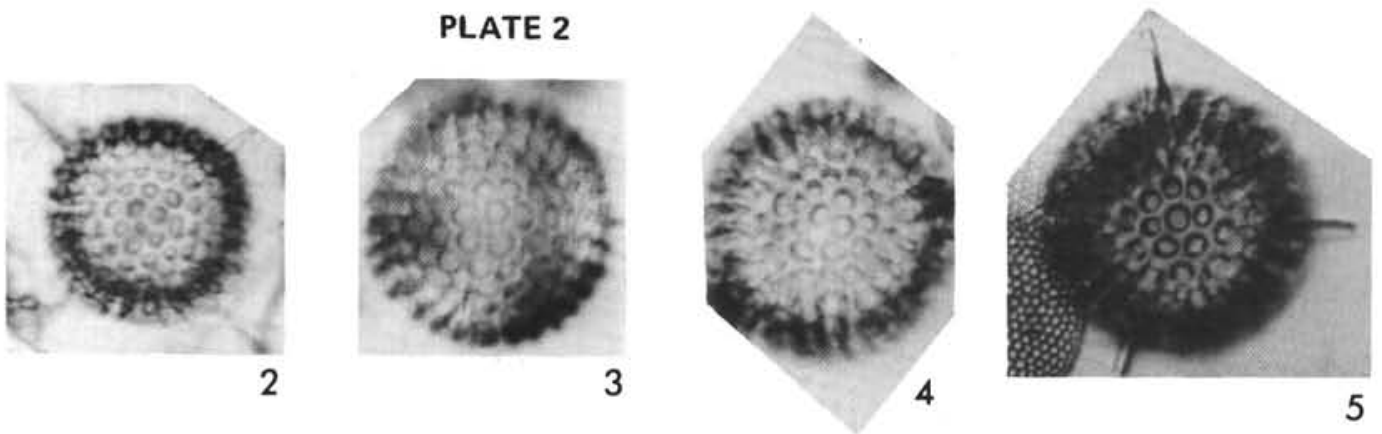
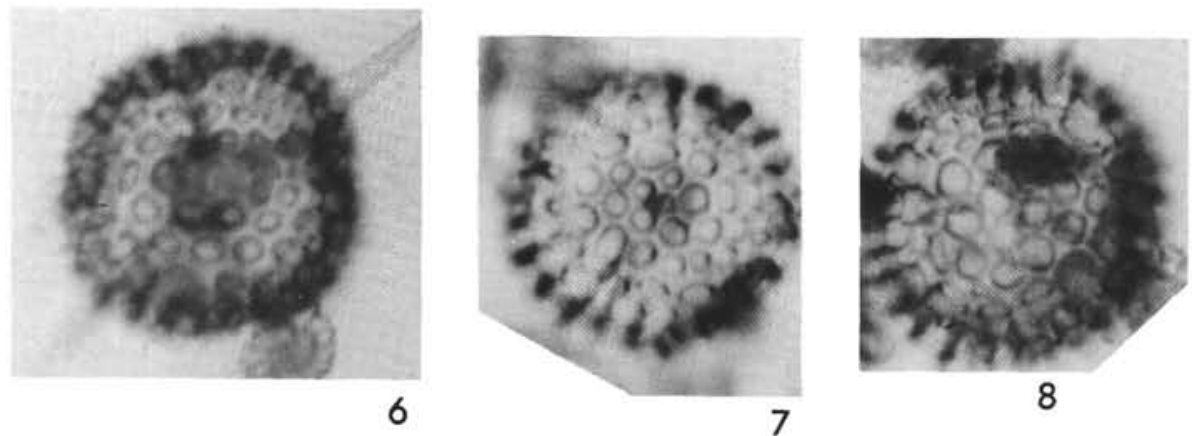

8
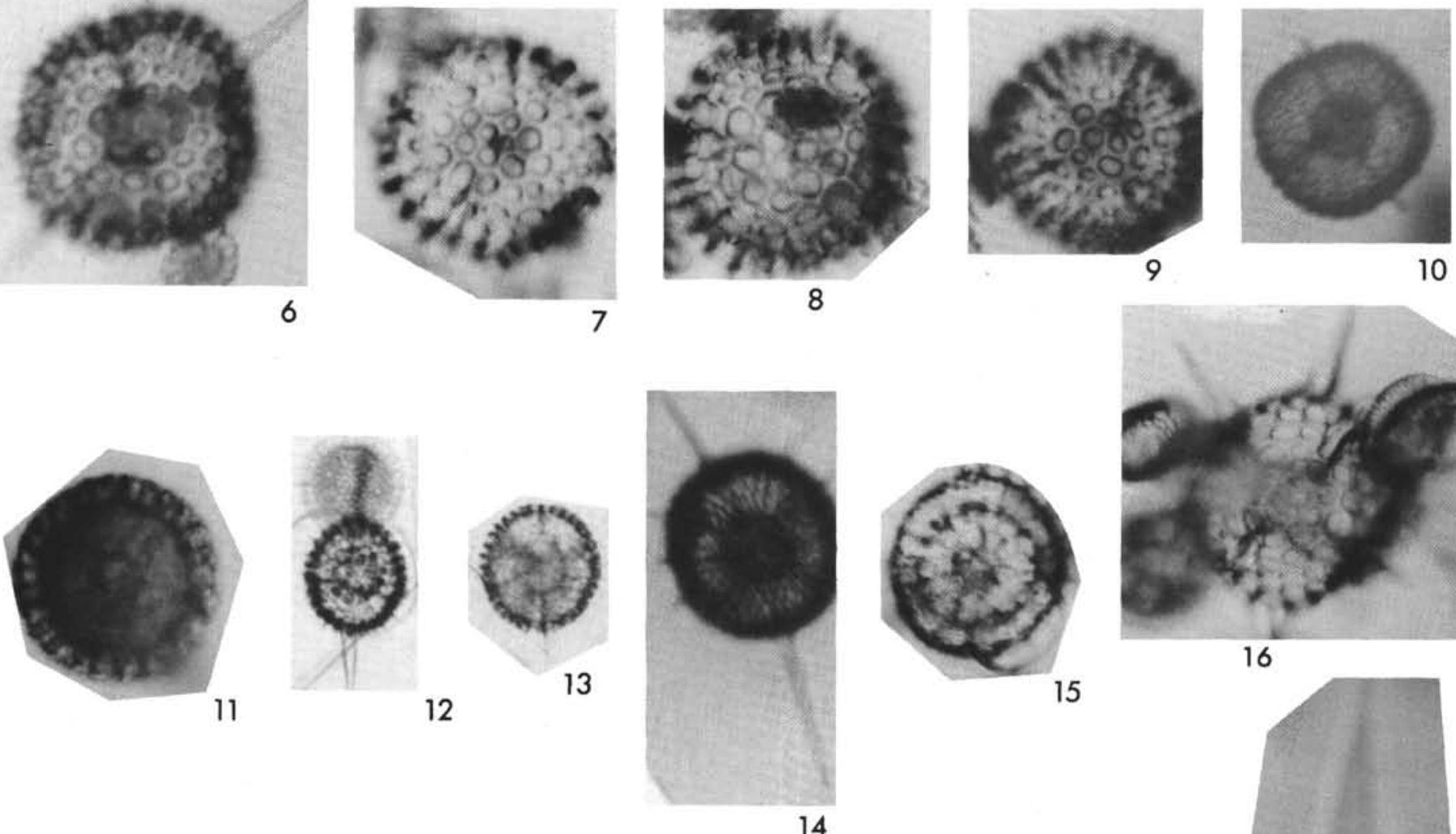

12
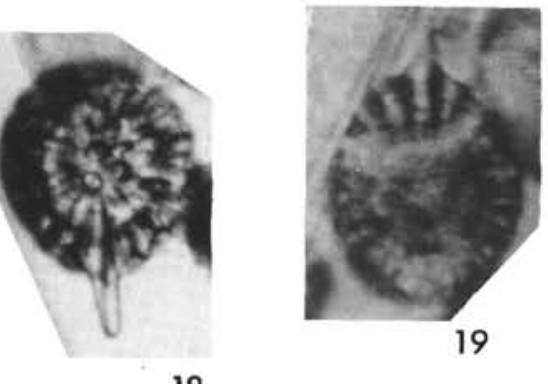

18

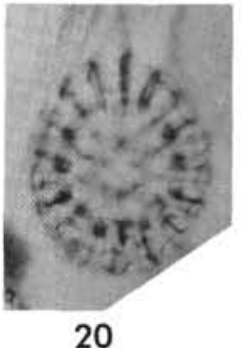

20
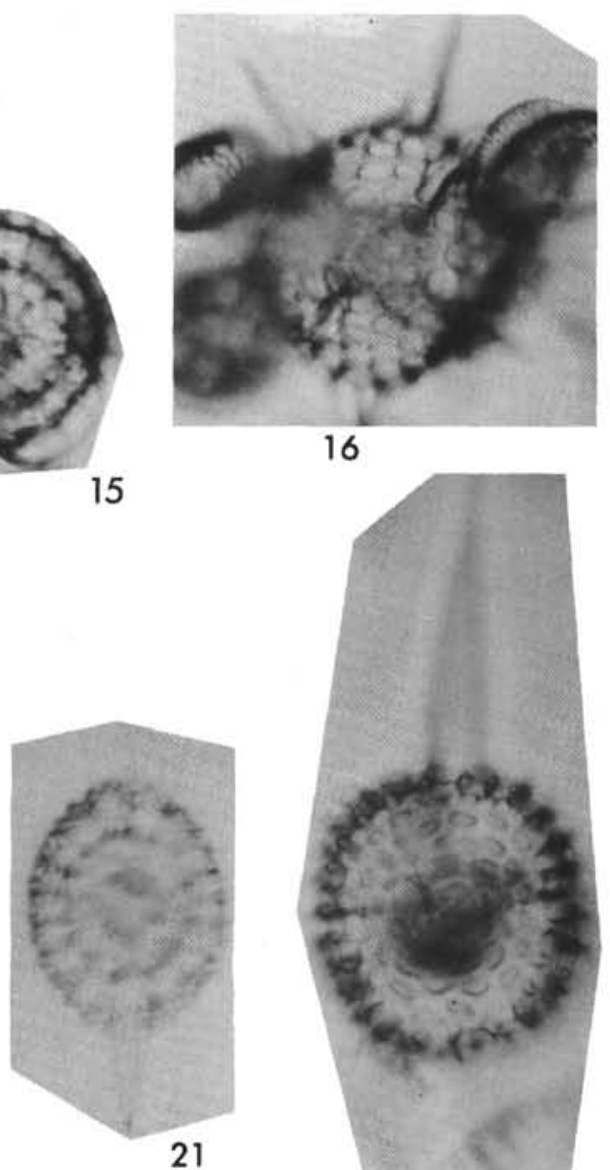

22 


\section{PLATE 3}

Figures 1, 2, 4, 6-14, $\times 200$; Figure 3, $\times 250$; Figure 5, $\times 100$.

Figure $1 \quad$ Lithelius ? nautiloides Popofsky Form P. Ob Station $268,113-115 \mathrm{~cm}$.

Figure 2 Lithelius sp. E. 29-281-16-5.

Figure 3 Lithelius ? nautiloides Popofsky Form P. Ob Station 117.

Figure 4 Lithelius (?) foremanae Sanfilippo and Riedel Form "small". 29-278-33-2.

Figure $5 \quad$ Lithelius ? nautiloides Popofsky group. Ob Station 17; surface sediment.

Figures 6-8 Lithocarpium polyacantha (Campbell and Clark) group.

6, 7. 29-278-32-5.

8. 29-280A-7-2.

Figure 9 Lithocarpium ? sp. 29-281-6, CC.

Figures 10, 11 Pylospyra (?) sp. A.

10. $29-278-33-6$.

11. $29-278-33-5$.

Figures 12-16 Ommatodiscus haeckeli Stöhr group 12-14. 29-278-12-1.

15, 16. 29-278-33-2. 
PLATE 3
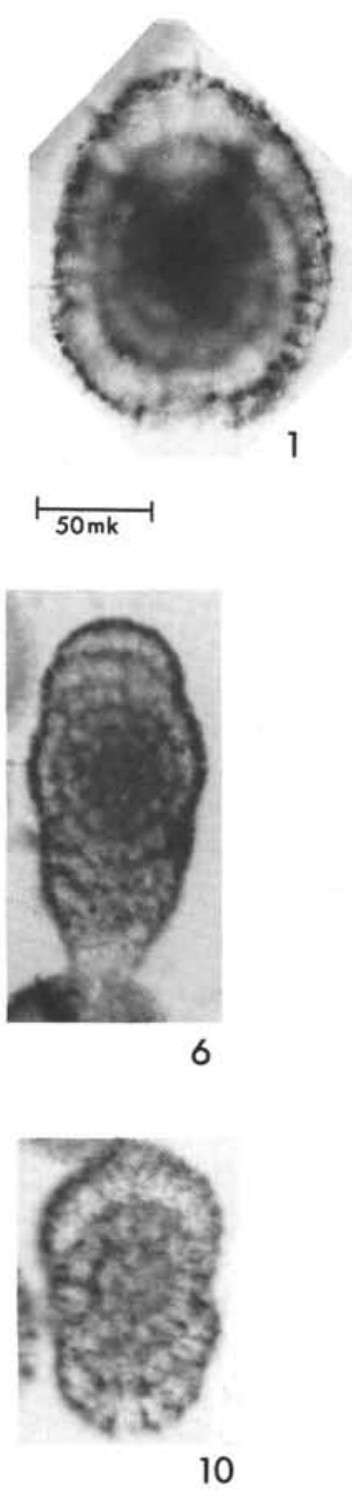
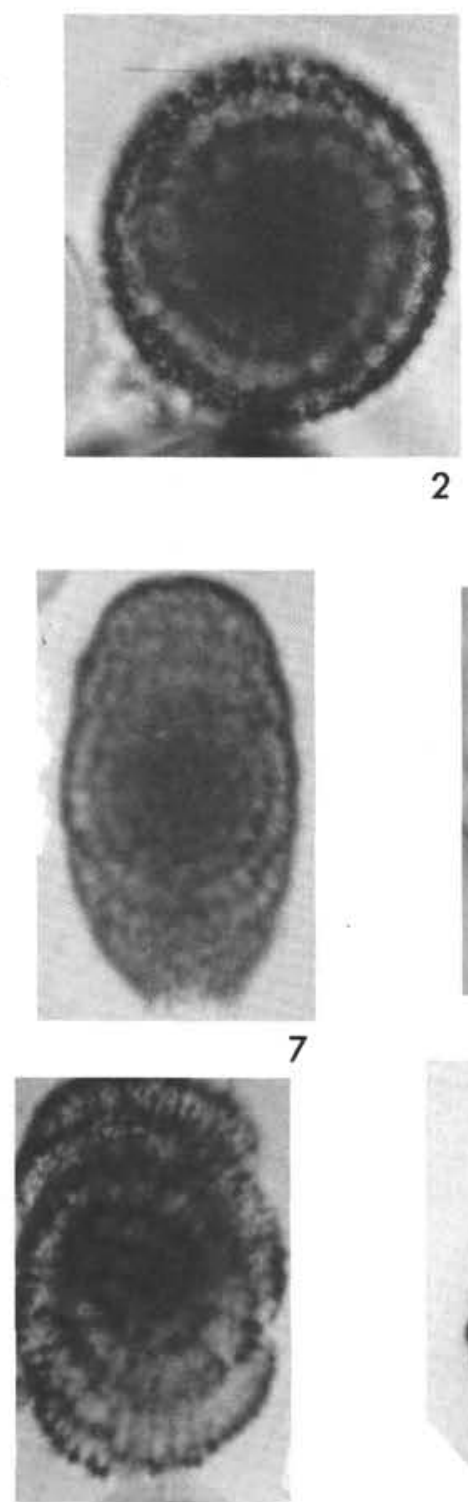

11

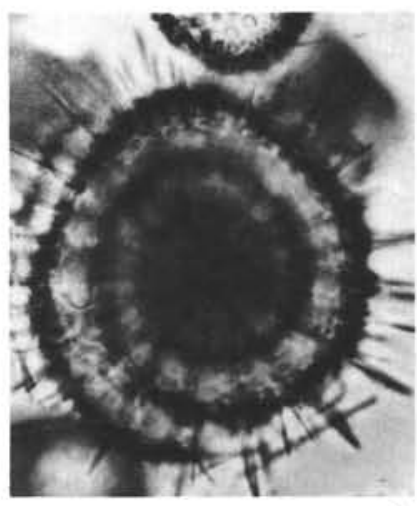

3
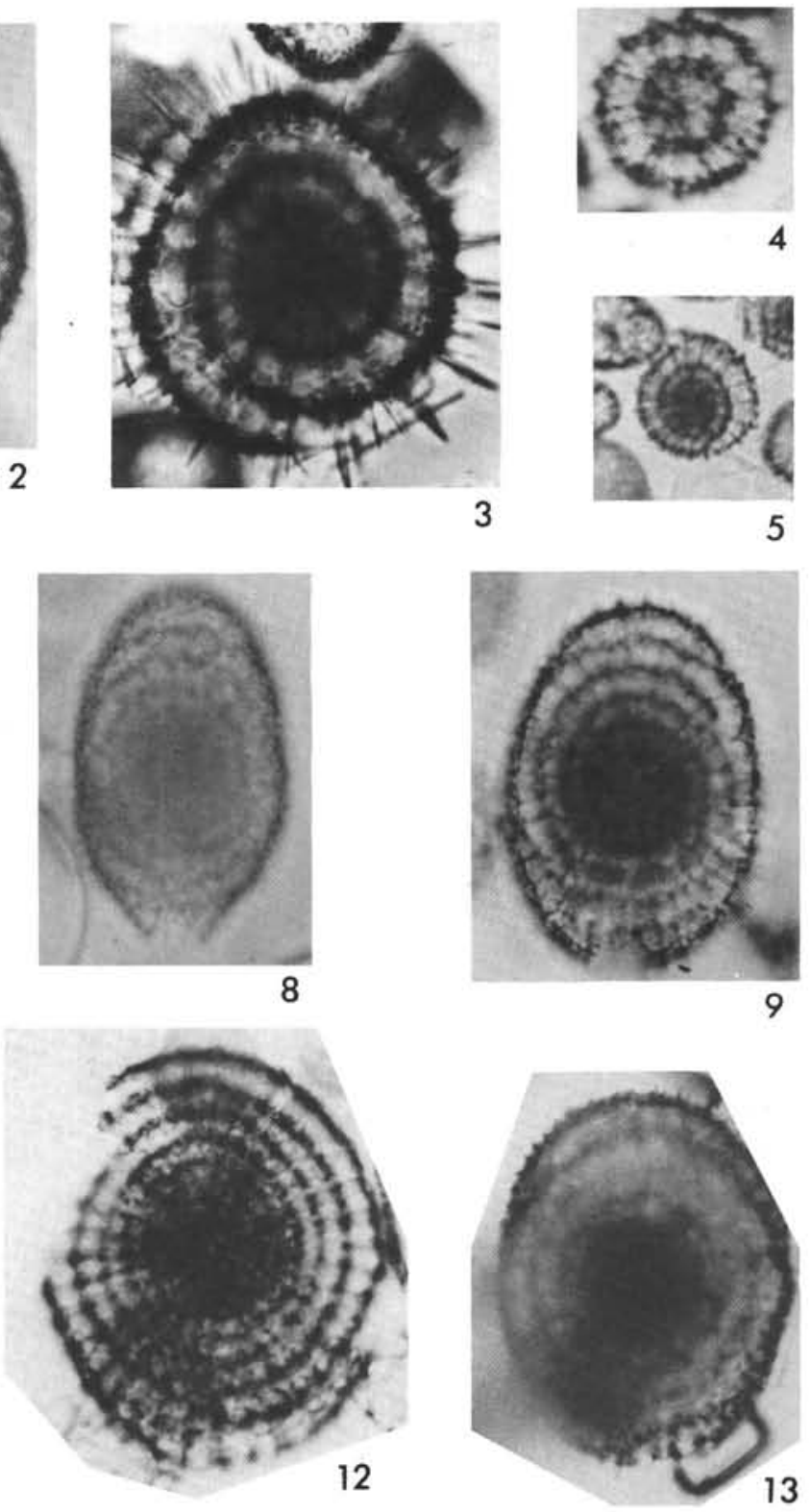
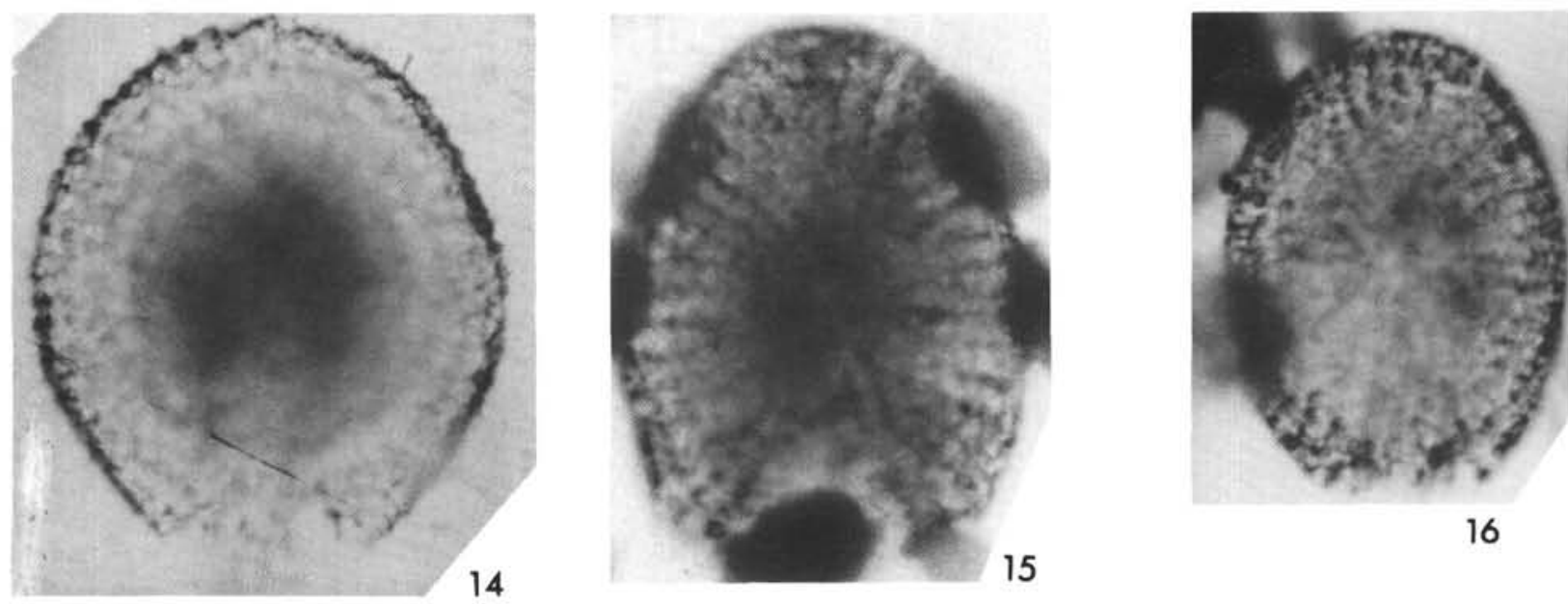


\section{PLATE 4}

Figure 1 Sponguridae gen. sp. D. 29-278-12-2.

Figures 2-4 Lithocarpium fragilis (Stöhr).

2. $29-278-12-2$.

3. $29-278$.

4. 29-278-14-4.

Figure 5 Lithocarpium titan (Campbell and Clark). California.

Figures 6-10 Lithocarpium monikae n. sp. 29-280A-3-4. 6, 7. Holotype. 
PLATE 4
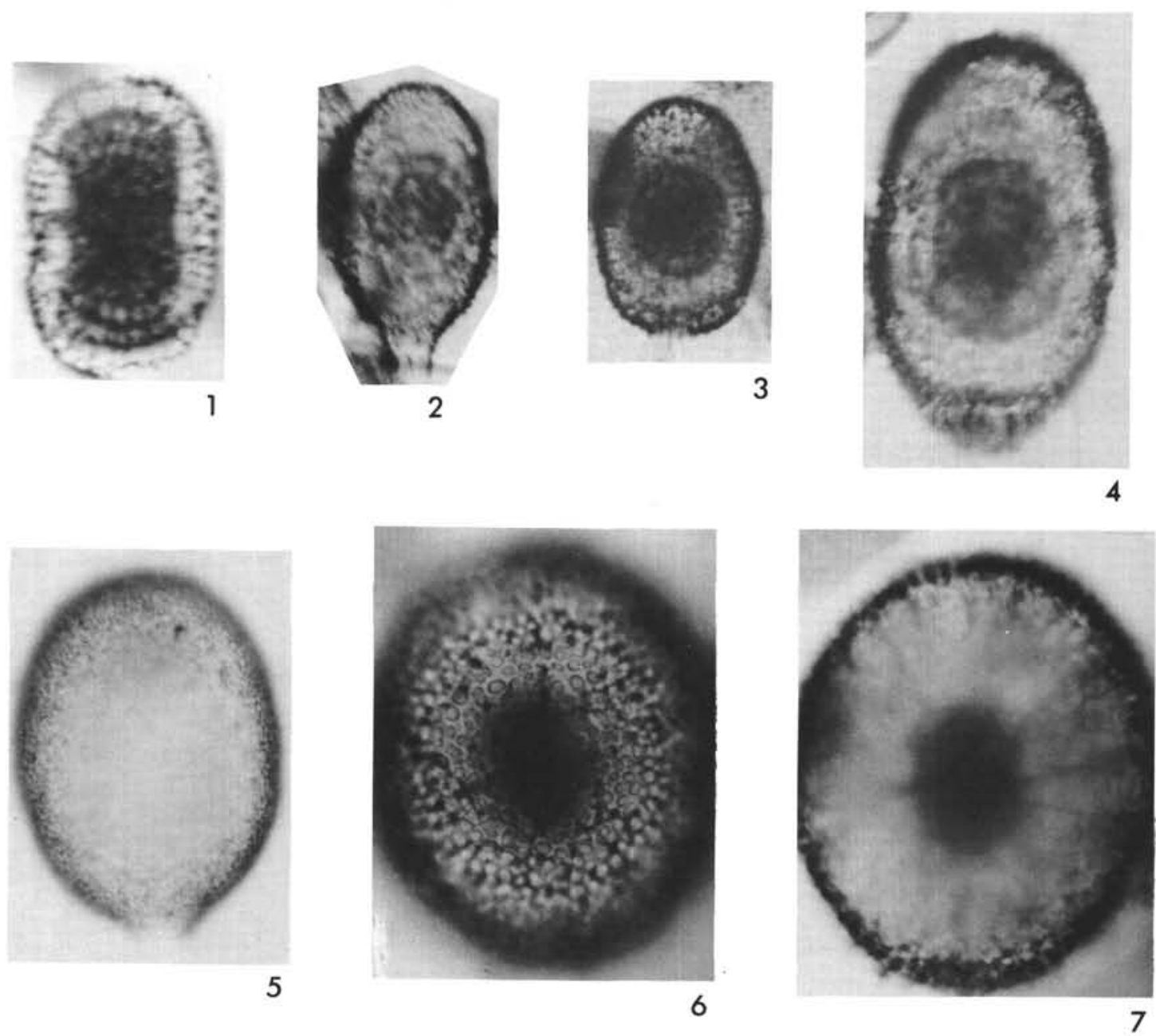
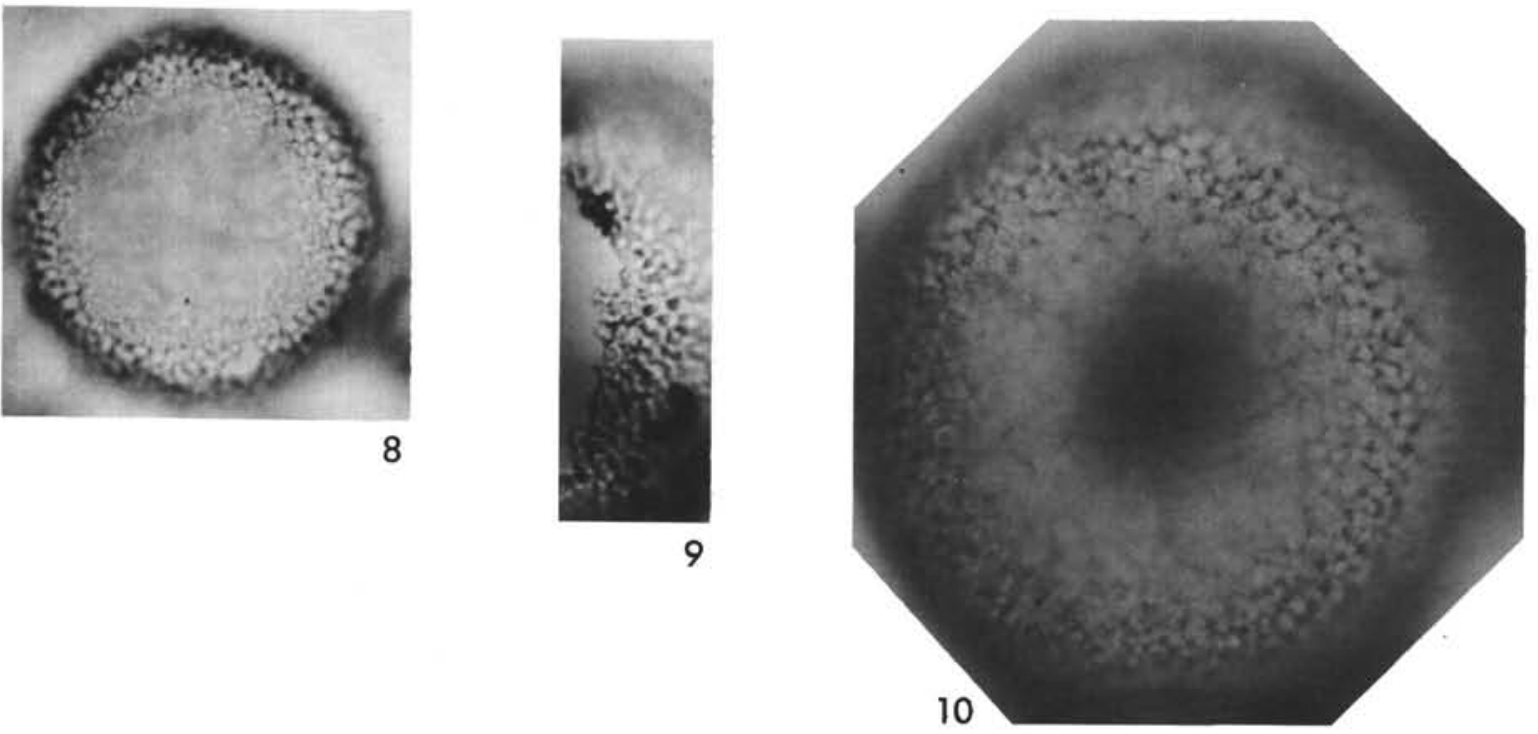


\section{PLATE 5}

Figures 1-5, 8-11, $\times 200$; Figures 6, 7, ×100.

Figures 1-4 Schizodiscus disymmetricus (Dogel) group. 29-27812-1.

Figure 5 Spongotrochus cruciferus Clark and Campbell. 29280A-10-5.

Figures 6,7 Schizodiscus favus (Ehrenberg) maxima (Popofsky). Ob Station 16, surface sediment.

Figure $8 \quad$ Spongotrochus glacialis Popofsky group. 29-27812-1.

Figures 9, 10 Spongodiscus craticulatus (Stöhr).

9. 29-278-14-4.

10. $29-281-16-5$.

Figure 11 Spongodiscus resurgens Ehrenberg osculosa (Dreyer). 29-278-12-1. 
PLATE 5
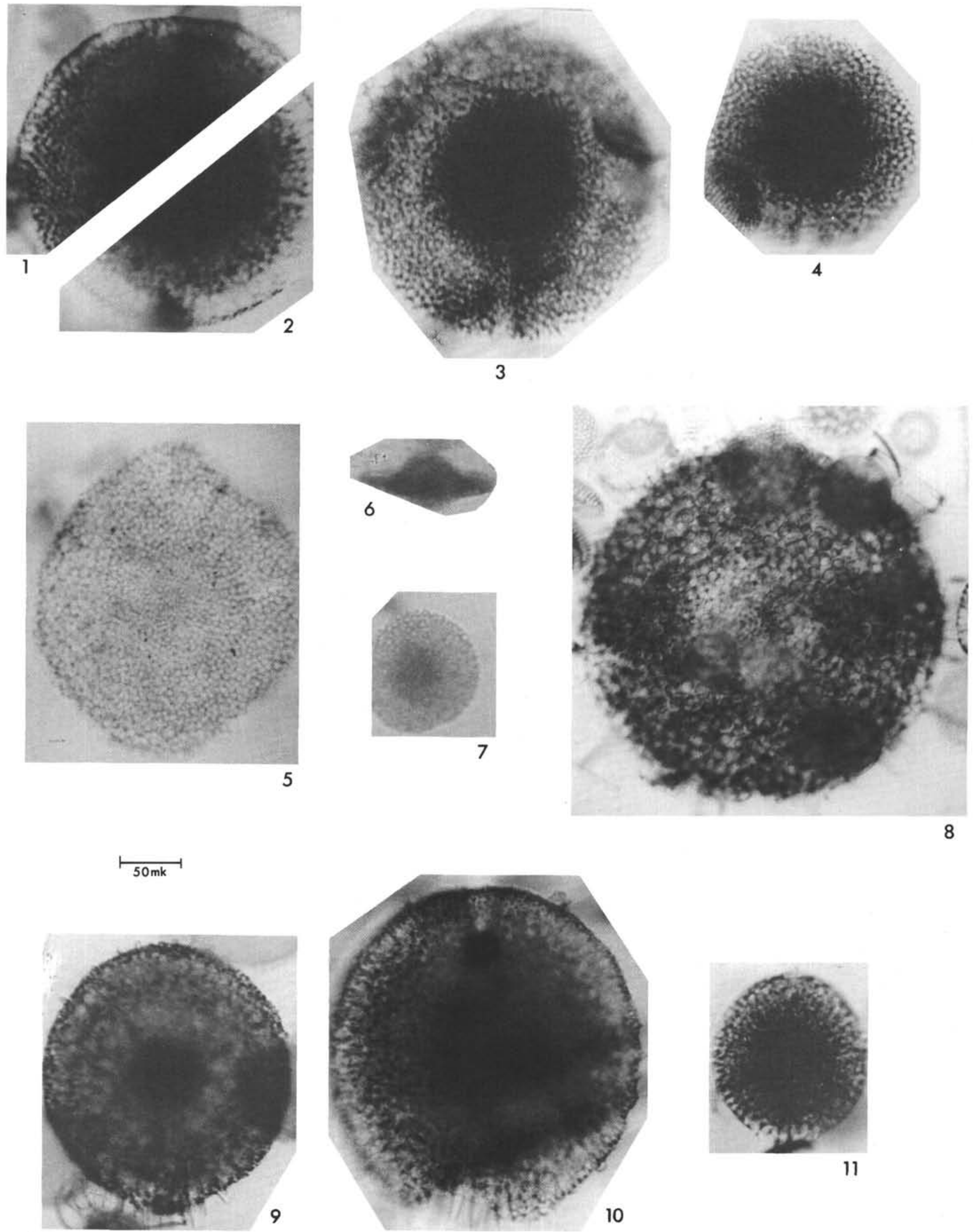
PLATE 6

All figures $\times 200$

Figures 1-6 Circospyris ellipticus (Stöhr) group.

1. 29-278-12-2.

2, 3. $29-278-12-1$.

4, 5. $29-278-12-2$.

6. $29-276-12-3$.

Figures 7, 8 Stylodictya targaeformis (Clark and Campbell). 29-281-16-3.

Figure 9 Stylodictya stellata Bailey group. 29-278-12-2.

Figure 10 Perichlamidium praetextum Ehrenberg. 29-278-121.

Figure 11 Perichlamidium limbatum Ehrenberg. 29-278-31-3.

Figure 12 Perichlamidium sp. aff. P. limbatum Ehrenberg. 29-280A-6, CC. 


\section{PLATE 6}
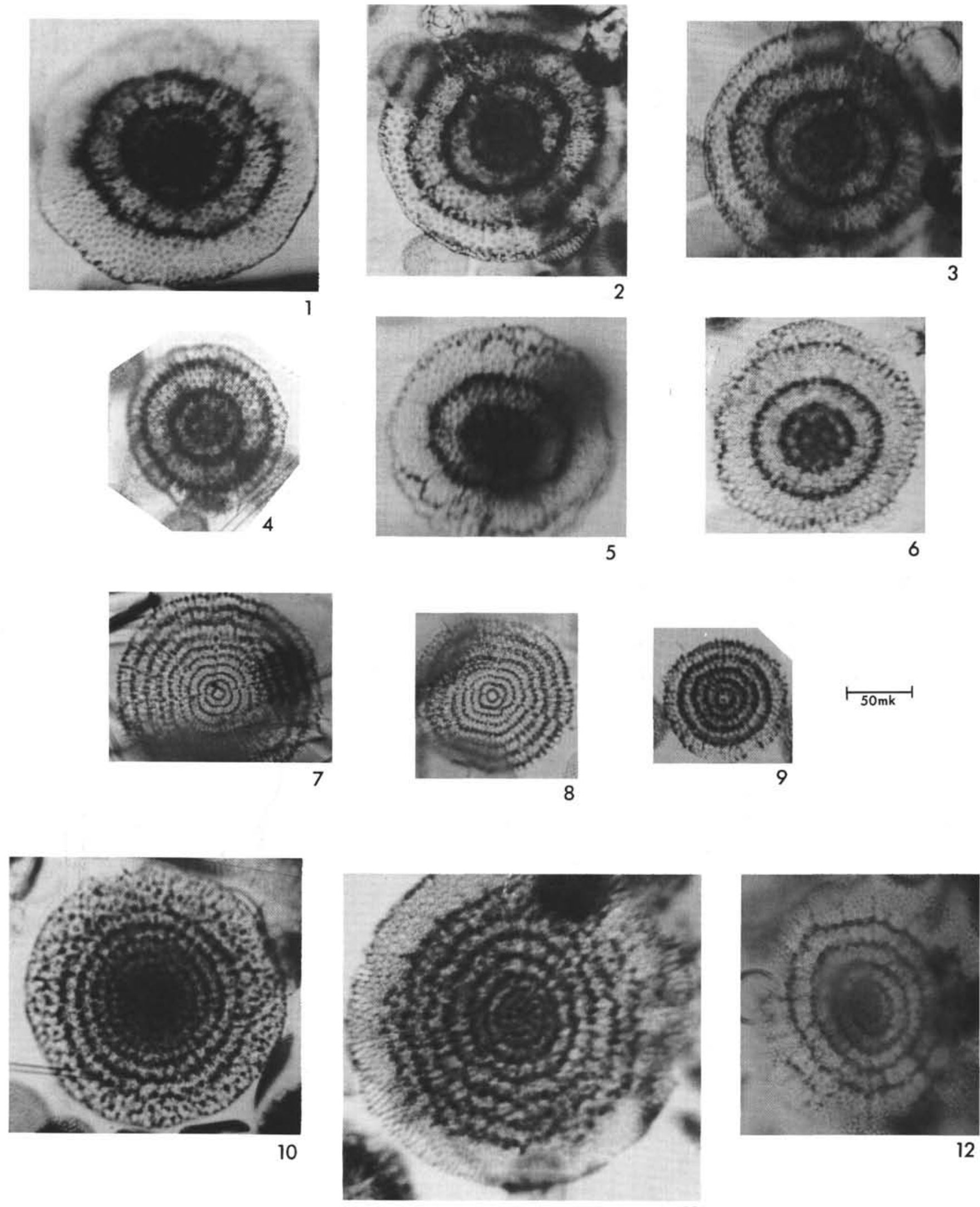


\section{PLATE 7}

Figures 1-3, 5-12, $\times 200$; Figure 4, $\times 100$

Figure 1 Amphymenium splendriarmatum Clark and Campbell group. 29-278-32-4.

Figure 2 Ommatogramma sp. 29-278-31-3.

Figure 3 Ommatogramma dumitrikai n. sp. 29-287-28-3; Holotype.

Figure $4 \quad$ Spongurus (?) pylomaticus Riedel. Ob Station 291, $294 \mathrm{~cm}$.

Figures 5-7 Cannartus (?) sp. aff. laticonus Riedel. 29-278-15-1.

Figure $8 \quad$ Cannartus (?) sp. 29-278-14-2.

Figures 9, 10 Cannartus laticonus Riedel. 29-281-6, CC.

Figure 11 Xiphospira ocellata (Ehrenberg). 29-280A-6, CC.

Figure 12 Stylodictya gracilis Ehrenberg. 29-278-28-4. 
PLATE 7

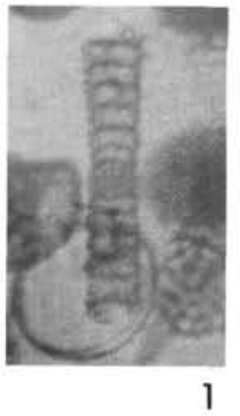

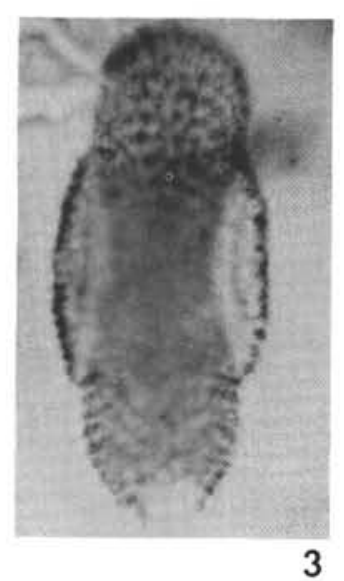

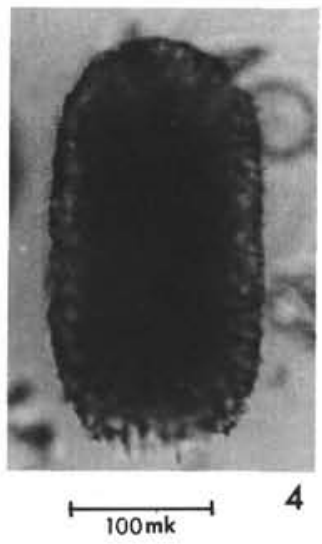

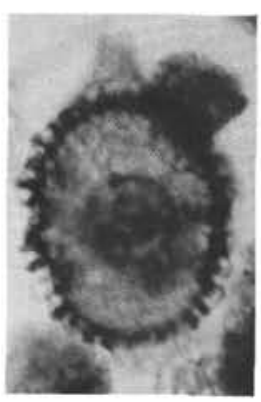

5
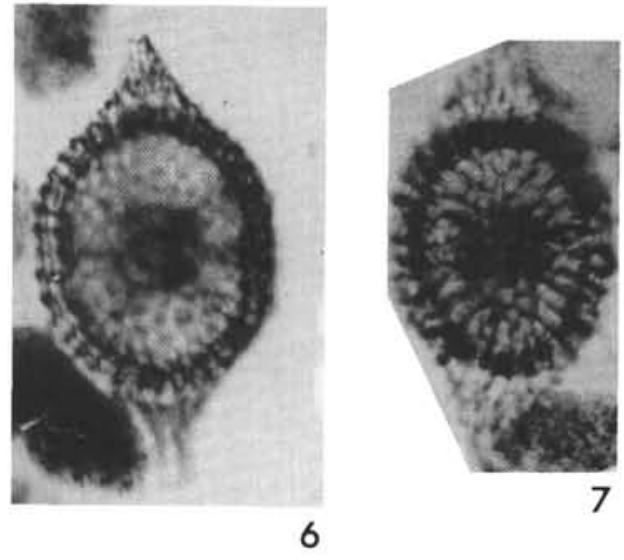
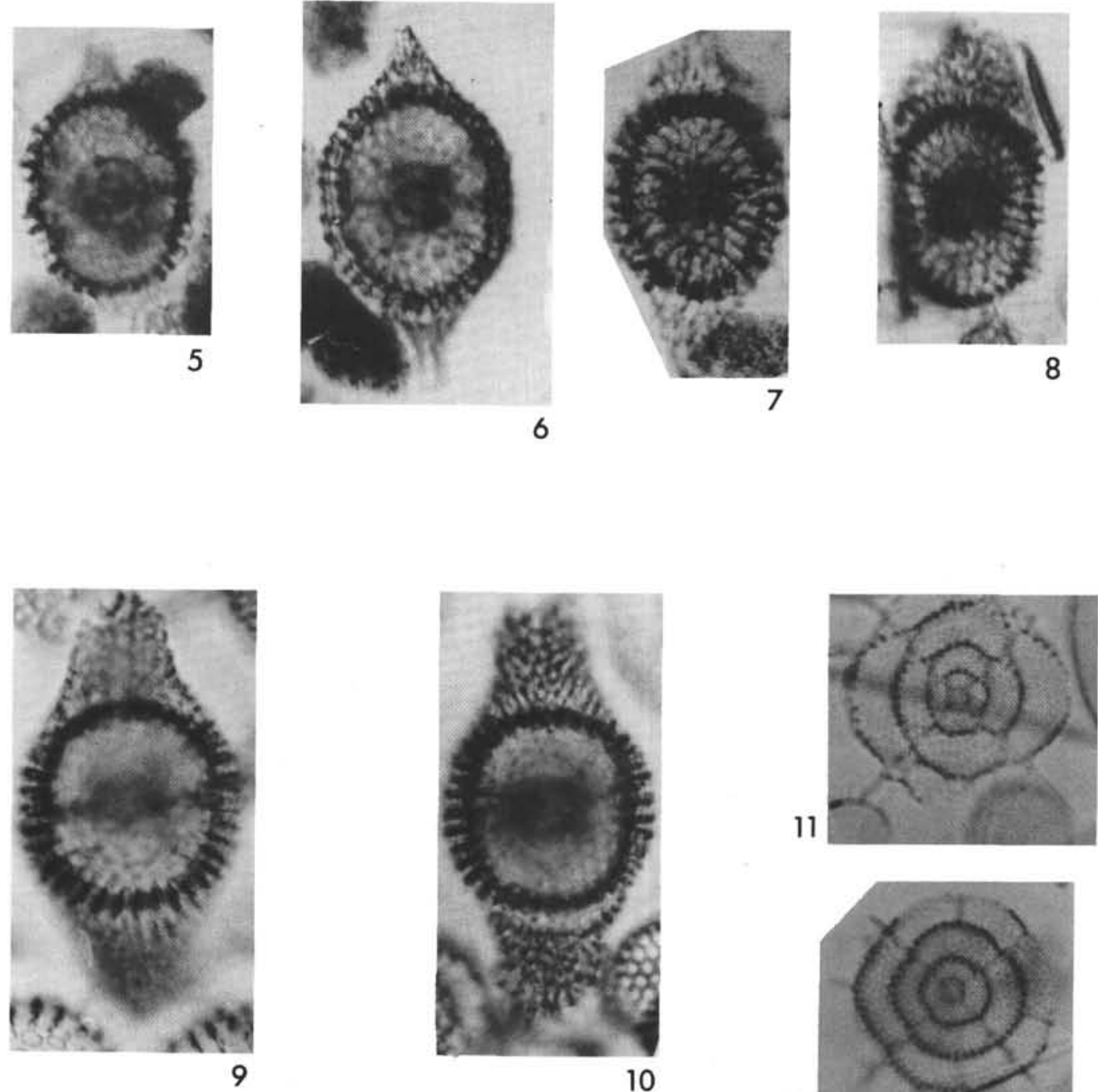

10

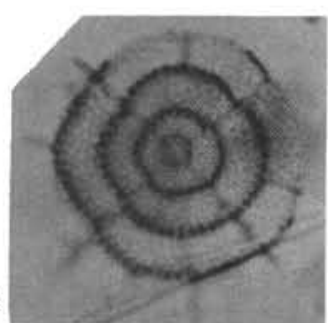




\section{PLATE 8}

Figure 1 Triceraspyris antarctica (Haecker) group. 29-278$28-4 ; \times 200$.

Figure 2 Tholospyris sp. Ob Station 256, $760 \mathrm{~cm} ; \times 200$.

Figures 3, $4 \quad$ Desmospyris haysi n. sp. $\times 200$.

3. $\mathrm{Ob}$ Station $256,220 \mathrm{~cm}$.

4. 29-281-6, CC; Holotype.

Figure $5 \quad$ Platybursa sp. $O b$ Station $256,980 \mathrm{~cm} \times 170$.

Figures 6, 7 Calocyclas (?) fragilis (Carnevale). 29-280A-7-2; $\times 200$.

Figure $8 \quad$ Calocyclas (?) semipolita Clark and Campbell. 29280A-7-2; $\times 200$.

Figure 9 Theocotyle robusta (Clark and Campbell). 29-278$31-2 ; \times 200$.

Figure $10 \quad$ Thyrsocyrtis sp. 29-281-16-3; $\times 200$.

Figures 11-13 Androcyclas heteropora (Hays).

11. $O b$ Station $268,111-115 \mathrm{~cm} ; \times 200$.

12, 13. $O b$ Station $256,980 \mathrm{~cm} ; \times 170$.

Figure 14 Theocorys cretica (Ehrenberg). Ob Station 126, 56 $\mathrm{cm} ; \times 170$.

Figure 15 Gondwanaria japonica (Nakaseko) group. 29-278$14-4 ; \times 200$.

Figure 16 Cyrtophormis sp. Ch Petrushevskaya and Kozlova. 14-144-2-2; Paleocene; $\times 250$.

Figures 17, 18 Theocorys longithorax n. sp.

17. 29-278-33-3.

18. 29-278-33-1; Holotype; $\times 200$.

Figure 19 Phormocyrtis sp. 14-144-2-1; Paleocene; $\times 275$.

Figures 20, 21 Eusyringium (?) striata (Brandt) group. 14-144-2-2, bottom; Paleocene; $\times 275$.

Figure 22 Cyrtophormis sp. Ch Petrushevskaya and Kozlova. 14-144-2-2, bottom; Paleocene; $\times 200$.

Figure 23 Buryella tetradicta Foreman. 14-144-2-2; $\times 200$. 

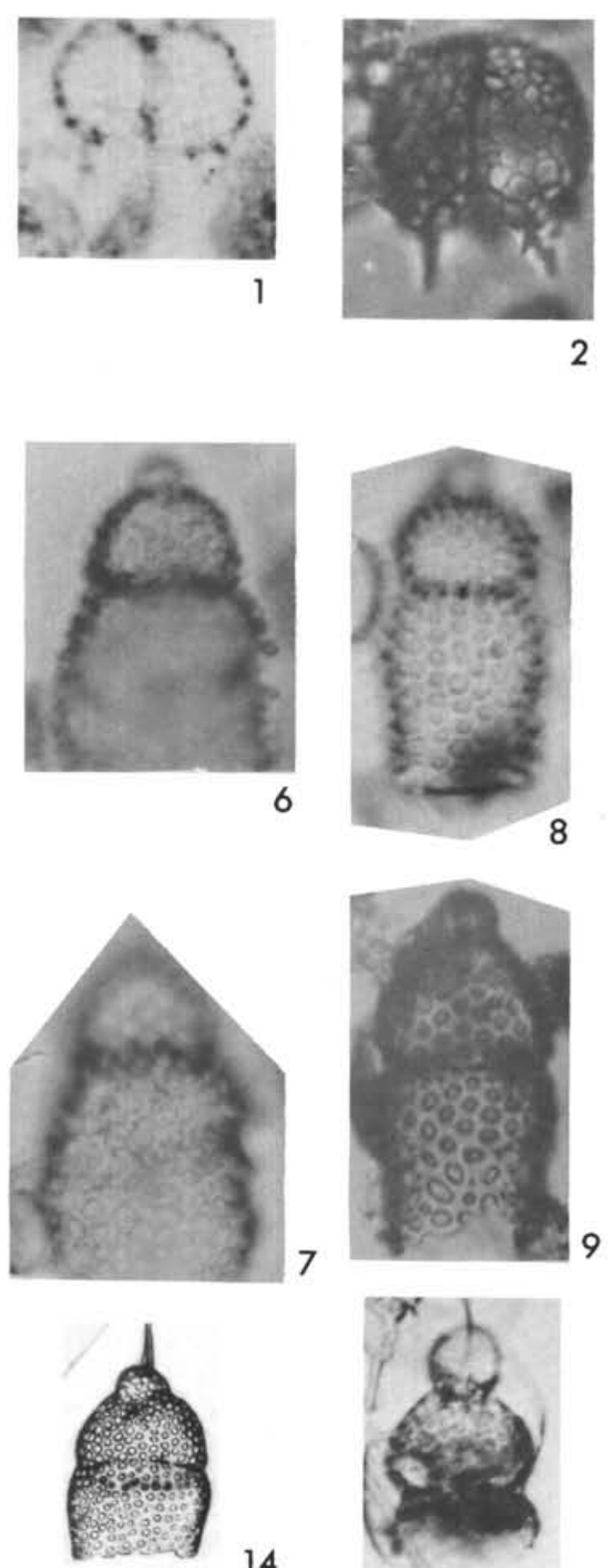

14

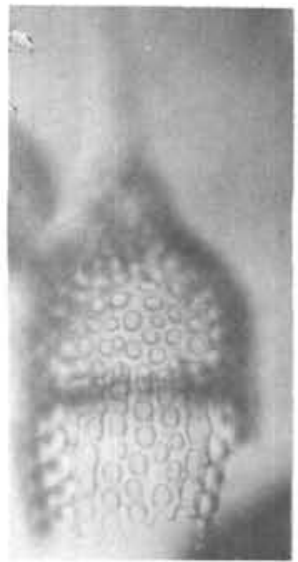

19
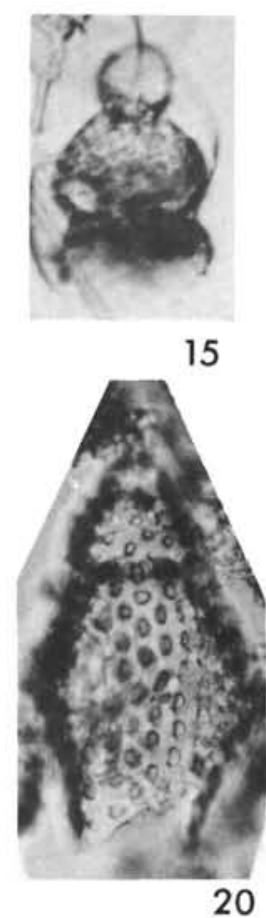

PLATE 8
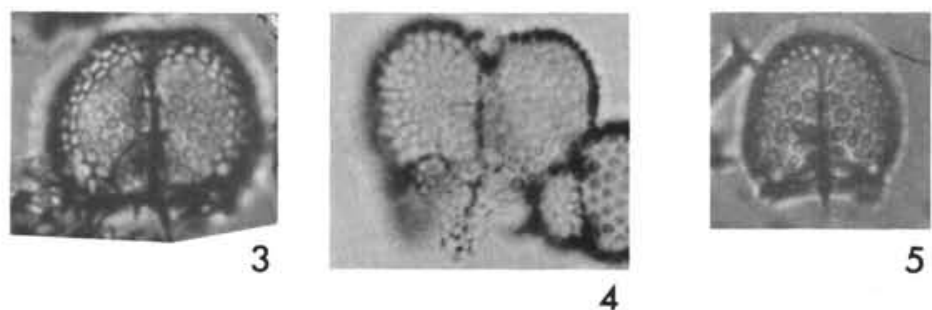

5

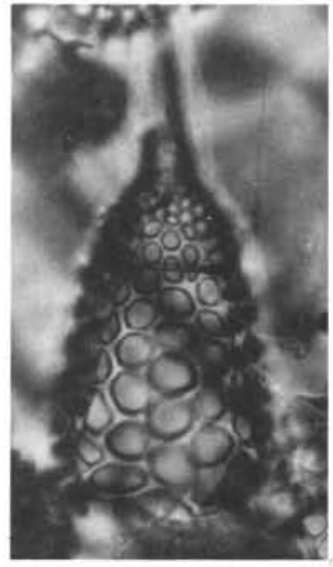

13

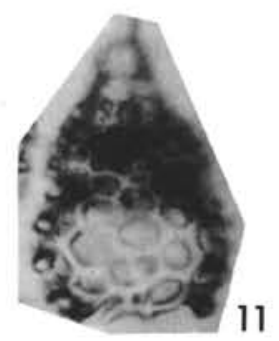

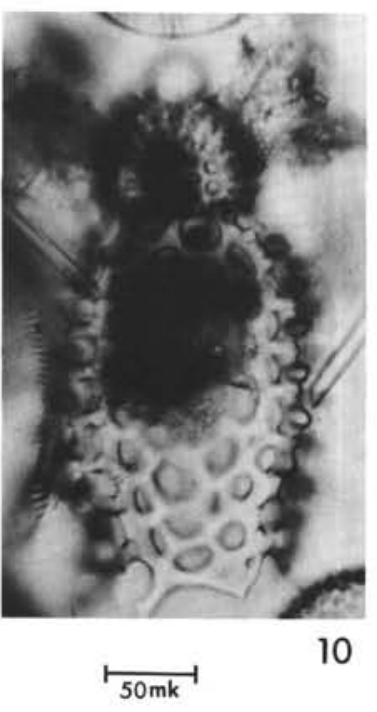
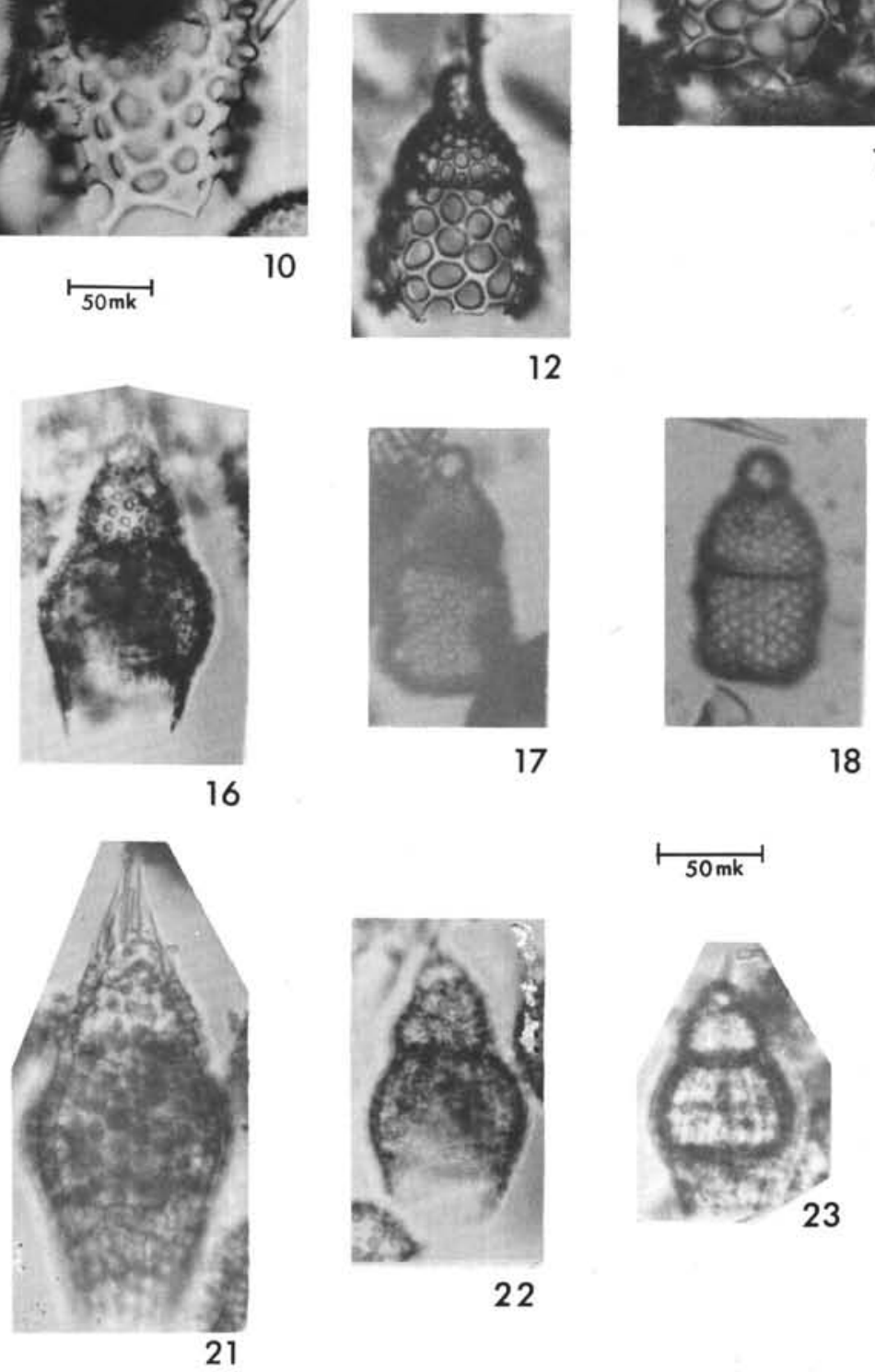

22 


\section{PLATE 9}

Figures 1-13, 15-20, 22-26, $\times 200$; Figure 14, ×180;

Figure $21, \times 220$.

Figure $1 \quad$ Clathrocorona sp. JYN V 16 P, Oligocene.

Figures 2-7 Gondwanaria japonica (Nakaseko).

2, 3. 29-278-12-1.

4-6. 29-278-14-4.

7. 29-278-153.

Figures 8, $9 \quad$ Gondwanaria deflandrei n. sp.

8. $O b$ Station $125,246-248 \mathrm{~cm}$.

9. 29-278-29-4; Holotype.

Figure 9 Lipmanella dictyoceras (Jörgensen) group. $\mathrm{Ob}$ Station $256,840 \mathrm{~cm}$.

Figure $10 \quad$ Lipmanella sp. P. Dumitrica Collection, Sample 1315.

Figures 11, 12 Gondwanaria deflandrei group. 29-278-33-2.

Figure $13 \quad$ Lophophaena (?) sp.

Figure 14 Gondwanaria hister n. sp. 14-139-5, CC; Holotype.

Figures 15, 16 Eucyrtidiidae gen. sp. indet. 14-144-2-2, bottom; Paleocene.

Figures 17-19 Arachnocorallium spp.

17, 18. 278-12-1.

19. $29-278-14-2$.

Figure $20 \quad$ Lophophaena sp. 278-12-1.

Figure $21 \quad$ Lophophaena (?) capito Ehrenberg group. 14-144B2-3, Paleocene.

Figure 22 Lophophaenoma sp. G. Petrushevskaya, 1971b, pl. 56, fig. 15; Barbados.

Figure 23 Lophophaenoma sp. 29-278-33-2

Figures 24-26 Lithomelissa (?) sp. aff L. haeckeli Bütschli.

24. 29-278-28-4

25. 29-281-16-5.

26. 29-278-33-1. 

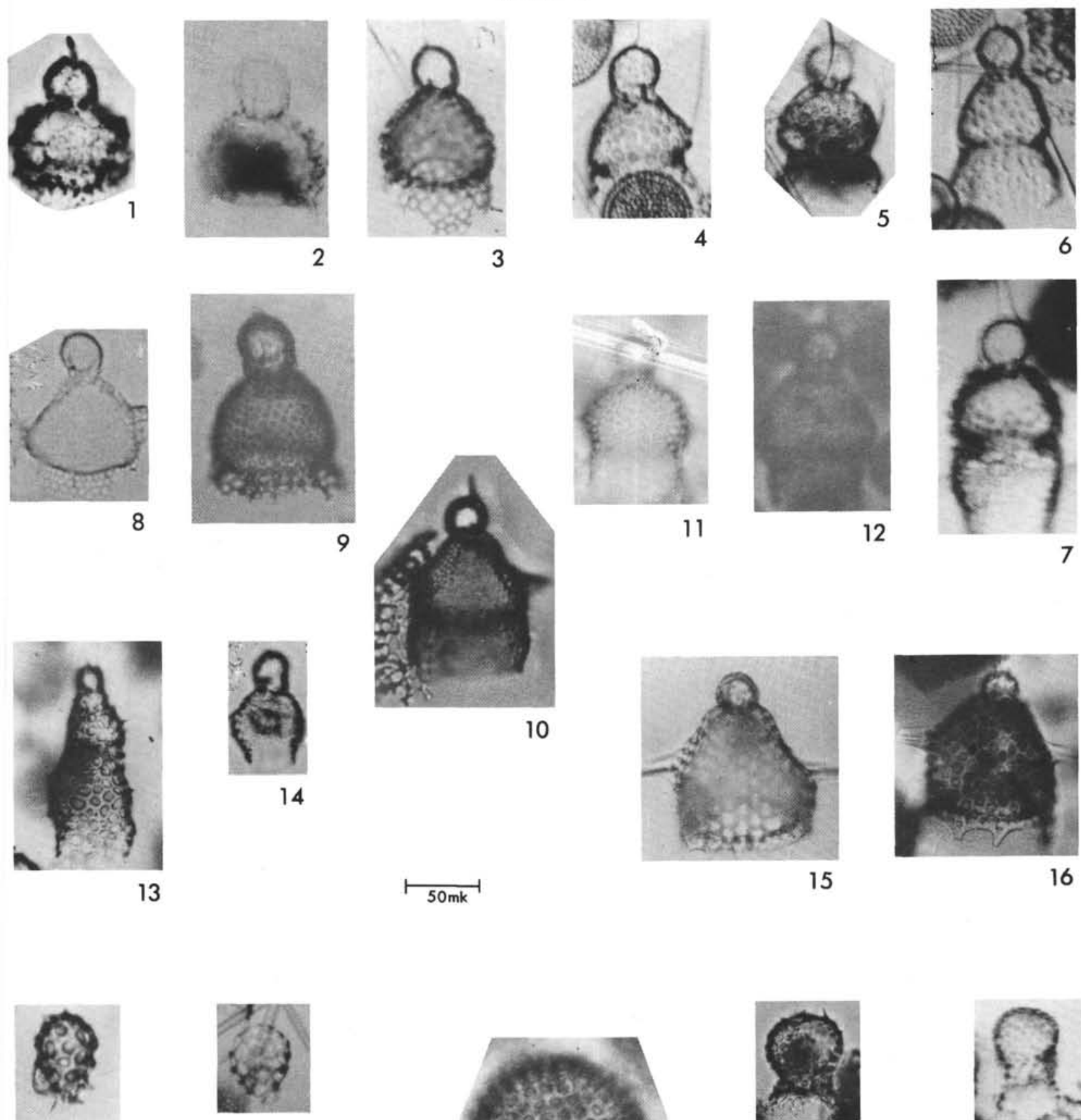

17

18
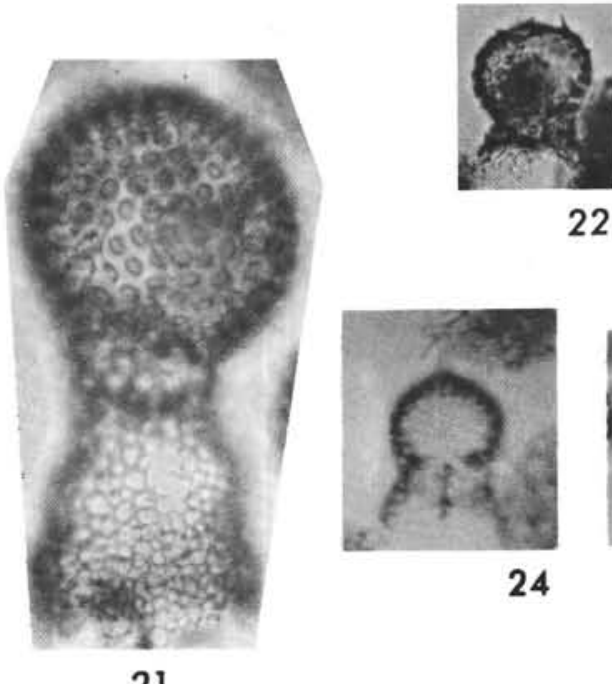

22
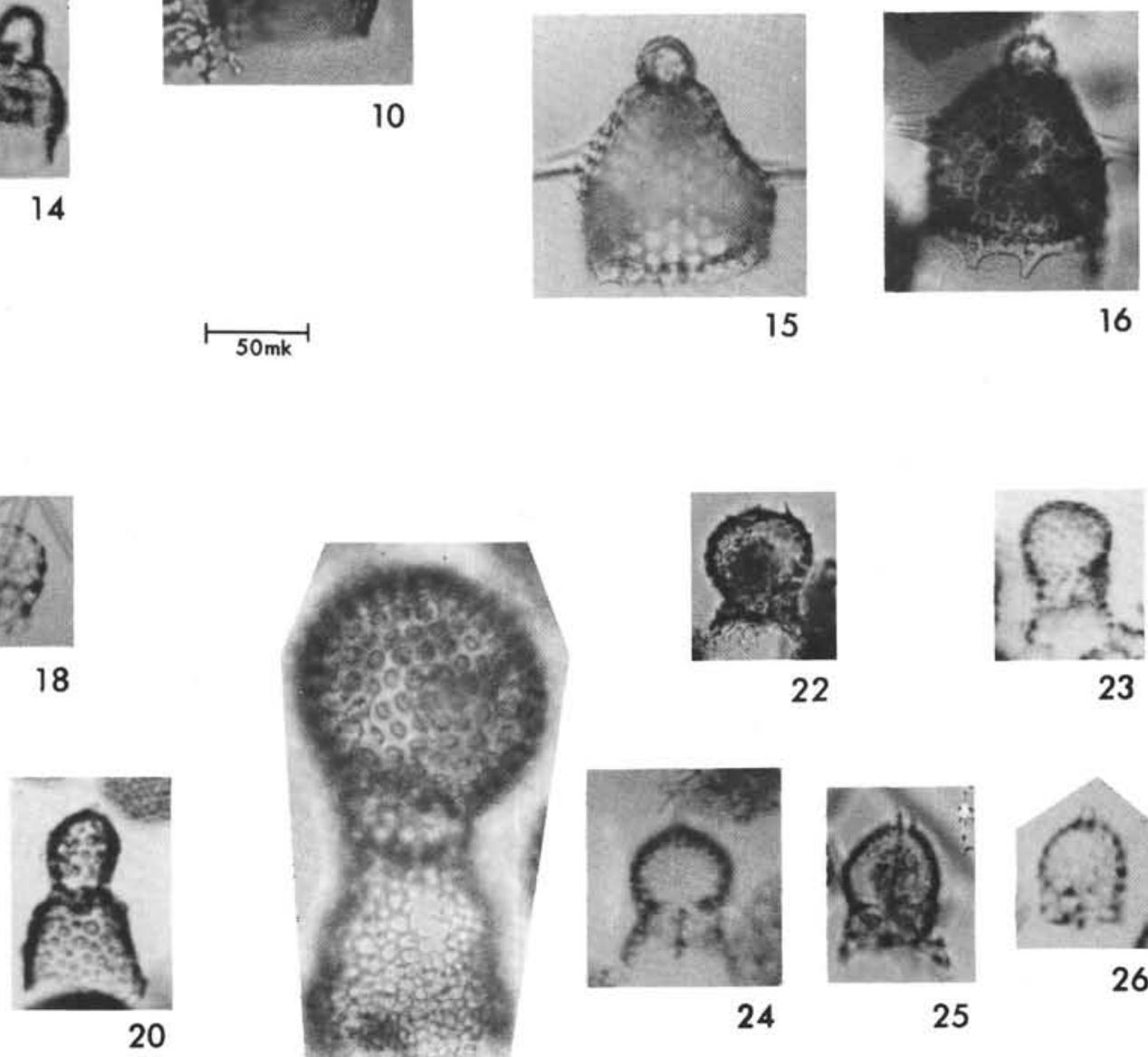

25

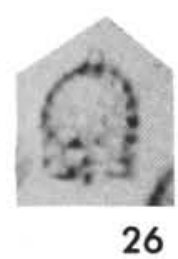

19

21 
PLATE 10

Figures 132, 34-37, $\times 200$; Figure $33, \times 250$.

Figure

Artostrobus sp. Cr. 14-144-2-2; Paleocene.

Figures 2, $3 \quad$ Artostrobus pretabulatus n. sp.

2. 29-278-31-3, holotype.

3. $\mathrm{Ob}$ Station $256,780 \mathrm{~cm}$.

Figures 4, $5 \quad$ Artostrobus annulatus Bailey.

4. $29-278-12-1$.

5. $29-278-12-2$

Figure 6

Theocampid multisegmented species. 1444-2-2; Paleocene.

Figure 7

Theocampe (?) minuta (Clark and Campbell). 29-278-34-1.

Figure 8

Lithomitra sp. 29-278-15-1.

Figure 9

Lithomitra modeloensis (Campbell and Clark) group. California, Malago Mudstone.

Figure 10

Lithomitra arachnea (Ehr.) group. Ob Station $256,780 \mathrm{~cm}$.

Figures 11, 12

Lithomitra sp. B. 29-280A-7-2.

Figures 13-17 Lithomitra arachnea (Ehrenberg) group.

13. California, Malago Mudstone.

14. $29-278-12-3$

15. $29-278-122$.

16. $29-278-12-1$

17. $29-278-14-4$

Figure 18

Lithomitra nodosaria Haeckel group. 29-278-33-6.

Figures 19, 20

Lithamphora quadrata Petrushevskaya and Kozlova. 14-144-2 2; Paleocene.

Figure 21

Lithamphora sp. 29-278-30-2.

Figures 22-24

Botryostrobus euporus (Ehrenberg) group.

22. $29-278-12-2$

23. $29-278-14-4$

24. California, Malago Mudstone.

Figures 25, 26 Botryostrobus tumidulus (Bailey) group. California, Malago Mudstone.

Figures 27-29, Desmospyris rhodospyroides $\mathrm{n}$. sp.

31,32

27. $29-278-12-2$

28. $29-278-12-5$

$29,31,29-278-12-1$

32. 29-278-12-2; Holotype.

Figure 30

Desmospyris (?) lata (Goll) 14-144-2-2; Paleocene.

Figures 33, 34

Desmospyris spongiosa Hays. Ob Station 117, $256 \mathrm{~cm}$.

Figure 35 Artostrobus annulatus (Bailey). Malago Mudstone, California.

Figure 36

Lithomitra (?) sp. 29-278-30-2.

Figure 37 
PLATE 10

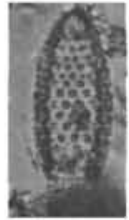

1

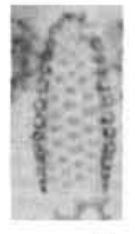

2

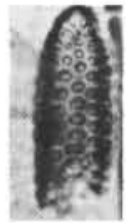

3

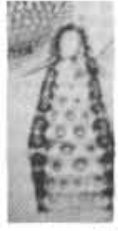

4

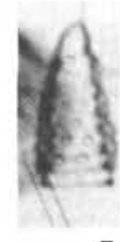

5

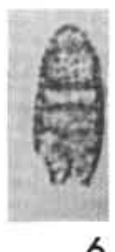

6

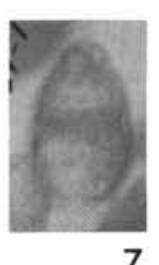

7

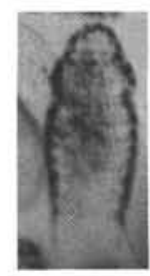

8
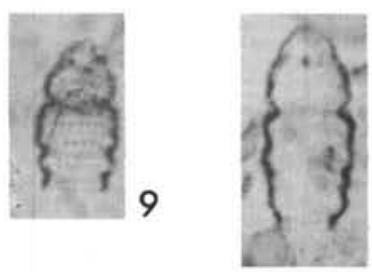

11

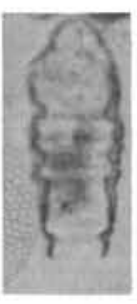

12
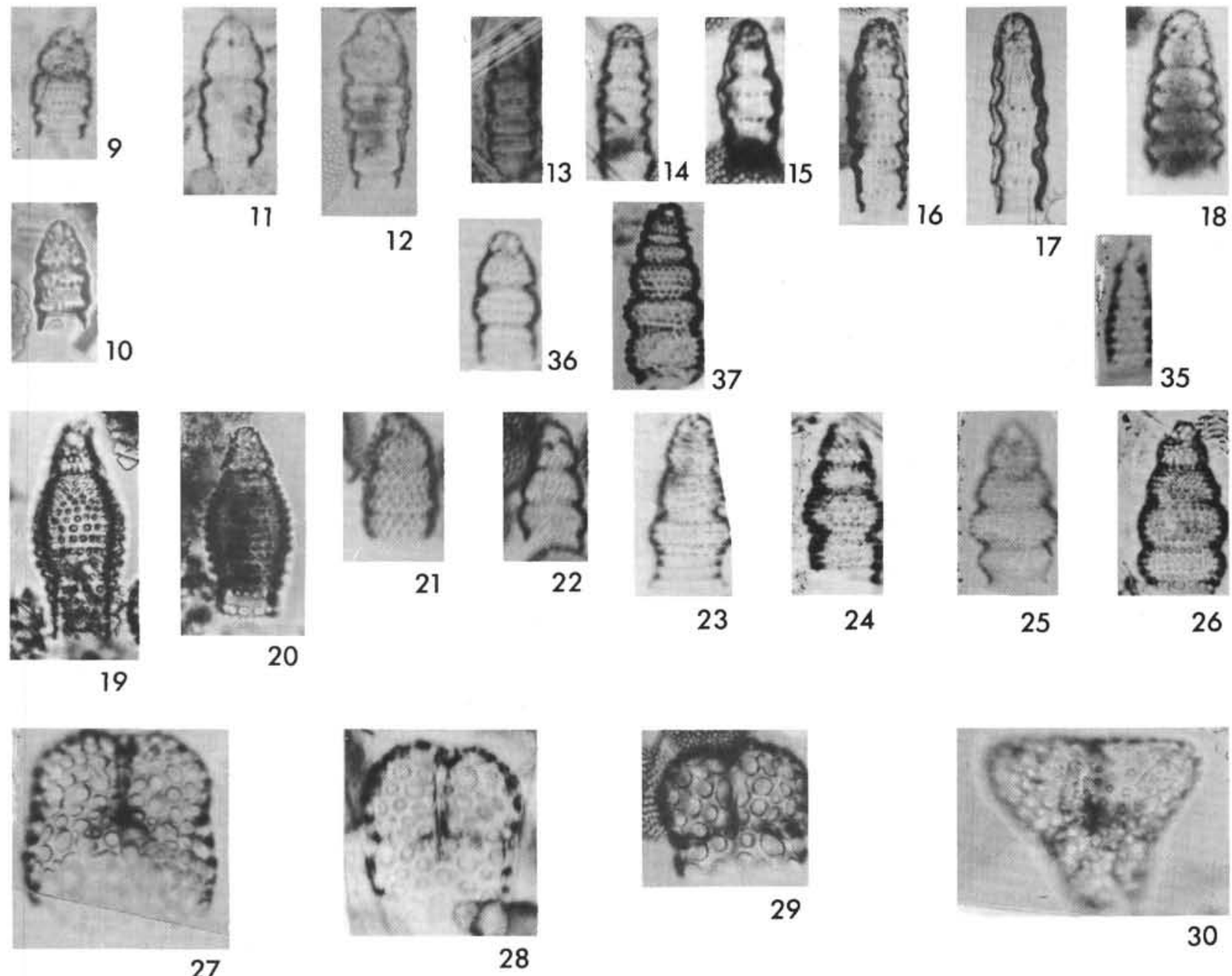

27

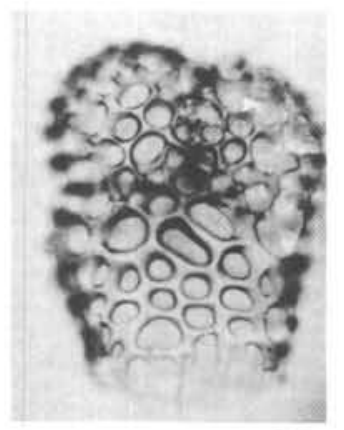

31
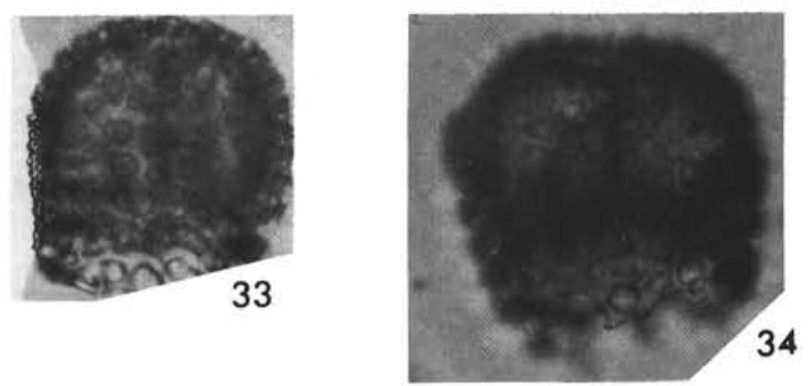
PLATE 11

Figures 1-6, 8-18, 2038, $\times 200$; Figures 7, 19, $\times 220$;

Figure $39, \times 300$

Figure 1

Figure 2

Figures 3-6

Figure 7

Figures 8-10

Figure 11

Figure 12

Figure 13

Figures 14,15

Figure 16

Figure 17

Figure 18

Figures 19, 20

Figures 21, 22

Figures 23, 25

Figure 24

Figure 26

Figures 27-29

Figures $30-32$

Figures 33, 34

Figure 35

Figures 36-39
Lithocampana sp. aff. L. lithoconella Clark and Campbell. 29 280A-6, CC.

Ceratocyrtis sp. aff. C. cucullaris (Ehrenberg). 29-280A-7-2.

Ceratocyrtis amplus (Popofsky).

3. 29-278-31-3.

4, 5. $29-278-29-3$.

6. 29-278-31-4.

Lophophaenoma (?) sp. 14-144B-2-2, bottom; Paleocene.

Antarctissa longa (Popofsky). Ob Station 117, 10-12 cm.

Corythomelissa sp. 14-144-2-2; Paleocene.

Ceratocyrtis sp. R. 29-278-29-3.

Ceratocyrtis amplus (Popofsky). 29-279-29-6.

Corythomelissa horrida $\mathrm{n} . \mathrm{sp}$.

14. 29-278-12-2.

15. $29-27833-1$.

Cladoscenium advena (Clark and Campbell) group. 29-278-33-1.

Pseudodictyophimus gracilipes (Bailey) group. 29-278-12-1.

Pseudodictyophimus (?) sp. 14-144-2-2; Paleocene.

Antarctissa cylindrica n. sp. Ob Station $117,10-12 \mathrm{~cm}$.

19. Holotype.

Antarctissa robusta $\mathrm{n} . \mathrm{sp}$.

21. 29-278-12-1.

22. 29-278-12-2; Holotype.

Antarctissa equiceps Campbell and Clark group. 29-278-12-1.

Antarctissa capitata Popofsky group. 29-278-12-3.

Lithomelissa (?) sp. aff. L. haeckeli Bütschli. 29-278-16-5.

Botryopera triloba (Ehrenberg) group.

27, 29. 29-278-15-1.

28. $29-278-12-1$.

Botryopera deflandrei sp.

30. 29-278-15-1; Holotype.

31. $O b$ Station $268,113-115 \mathrm{~cm}$.

32. $29-278-14-2$

Botryopera sp. aff. B. deflandrei. 29-278-15-1.

Botryopera sp. aff. B. boldyrae (Petrushevskaya) 29-278-15-1.

Botryopera triloba (Ehrenberg) group.

36, 37. 29-27812-1.

38. 29-278-15-1.

39. Photograph taken by K. Björklund from the specimen of Lithomelissa setosa Jörgensen from the plankton of the Norwegian Sea. 
PLATE 11

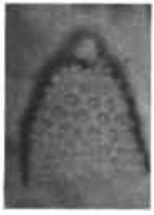

1
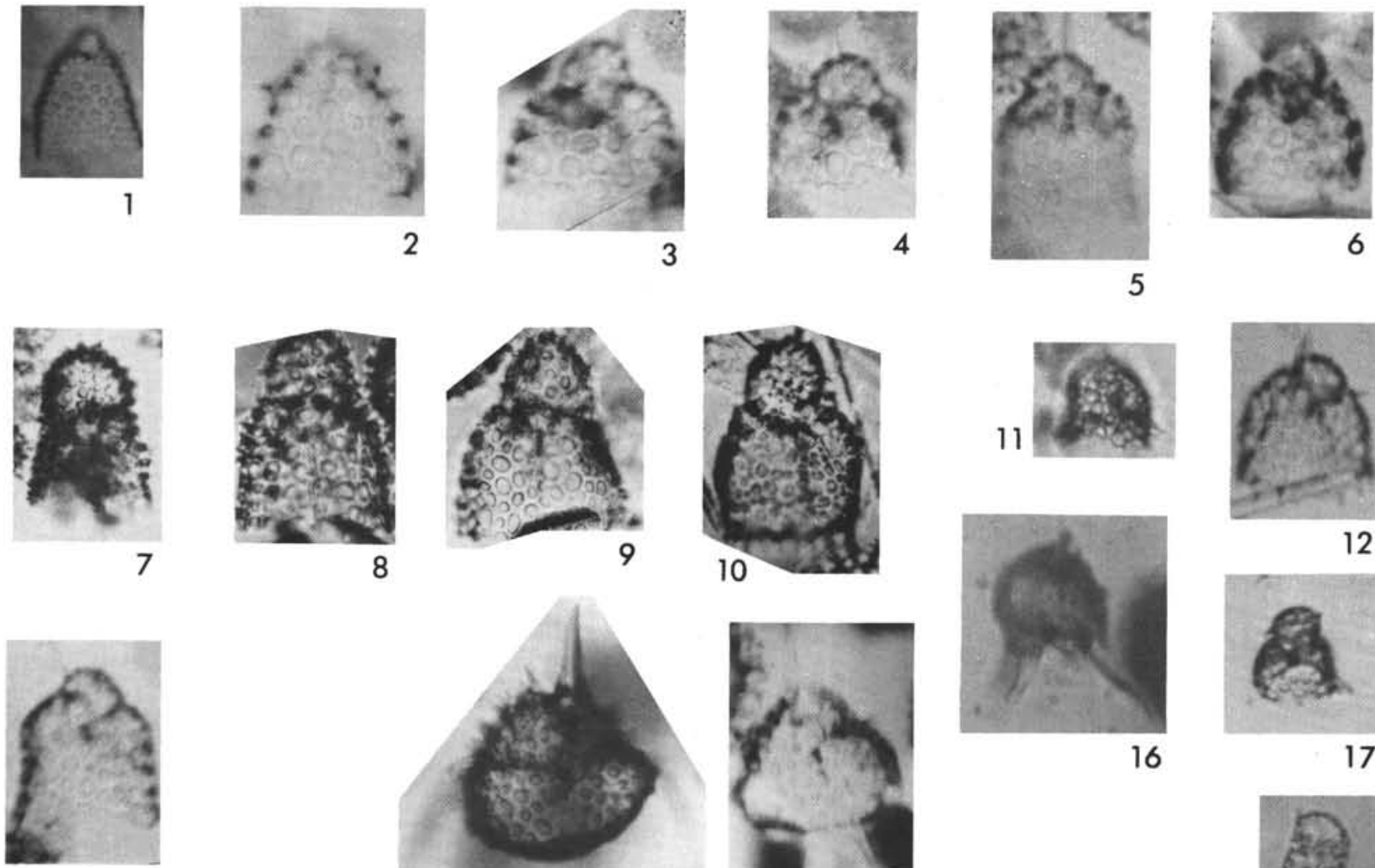

13
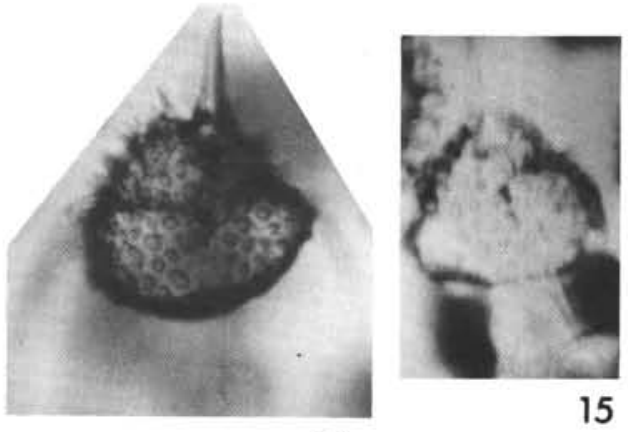

14
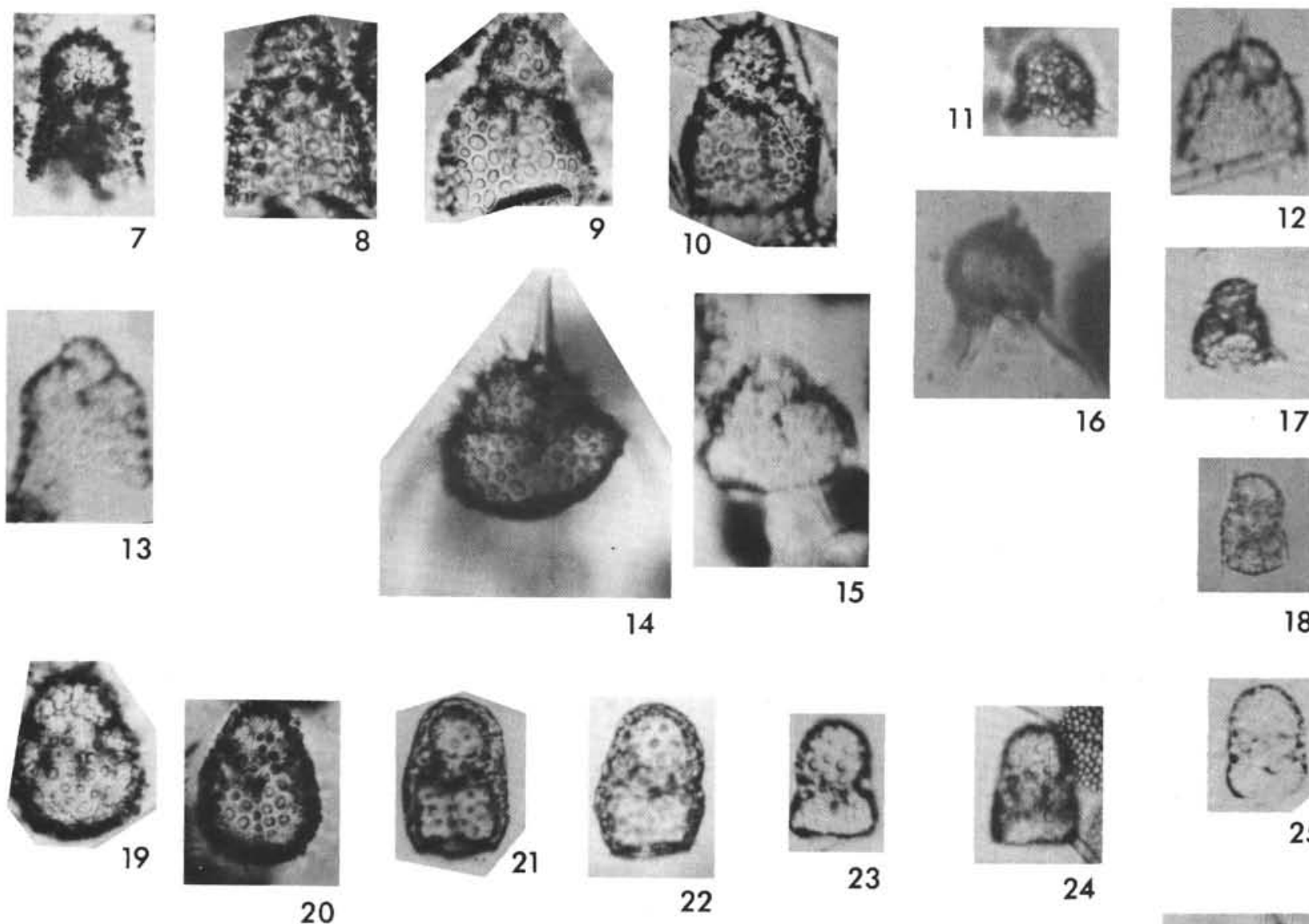

12

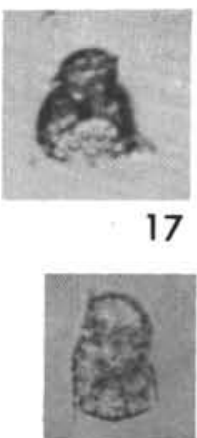

18
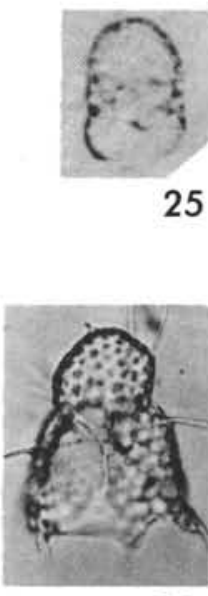

39

27
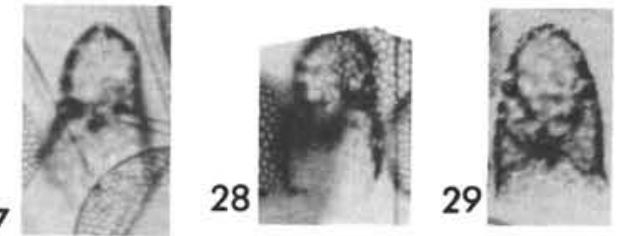

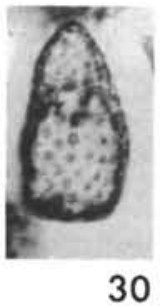

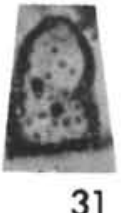

31

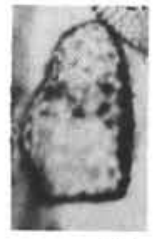

32

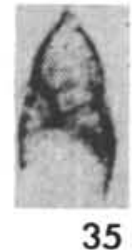

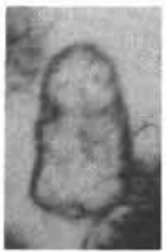

36

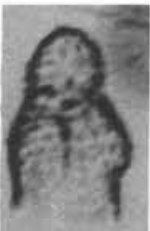

37

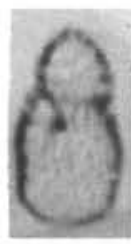

38 


\section{PLATE 12}

Figures 1-6, 8, 9. 11-16, $\times 200$. Figures $7,10, \times 250$

Figure 1 Lipmanella japonica (Nakaseko) group. 29-278-144.

Figure 2 Lychnocanella conica group. 29-278-14-1; Pedestal of the cephalis is seen.

Figure 3 Becoma sp. 14-144-2-2 bottom; Paleocene.

Figure 4 Lychnocanium sp. aff. L. grande. 14-139-1-2, 5-7 $\mathrm{cm}$.

Figures 5, 6 Lychnocanium grande Campbell and Clark.

5. 29-281-6, CC.

6. $29-278-14-1$.

Figure 7 Lychnocanium sp. Ob Station 212, 110-112 cm.

Figure 8 Lamprotripus mawsoni (Riedel). 29-278.

Figure 9 Archipilium sp. aff. A. macropus (Haeckel). $O b$ Station 256, 294-396 cm.

Figure 10 Theopera? pyramis (Haeckel). 14-144-2-3, Pliocene.

Figures 11-15 Lychnocanella conica (Clark and Campbell) group. 11. 29-278-12-1; atypical.

12, 14. 29-278-31-3.

13, 15. $29-278-32-5$ 
PLATE 12
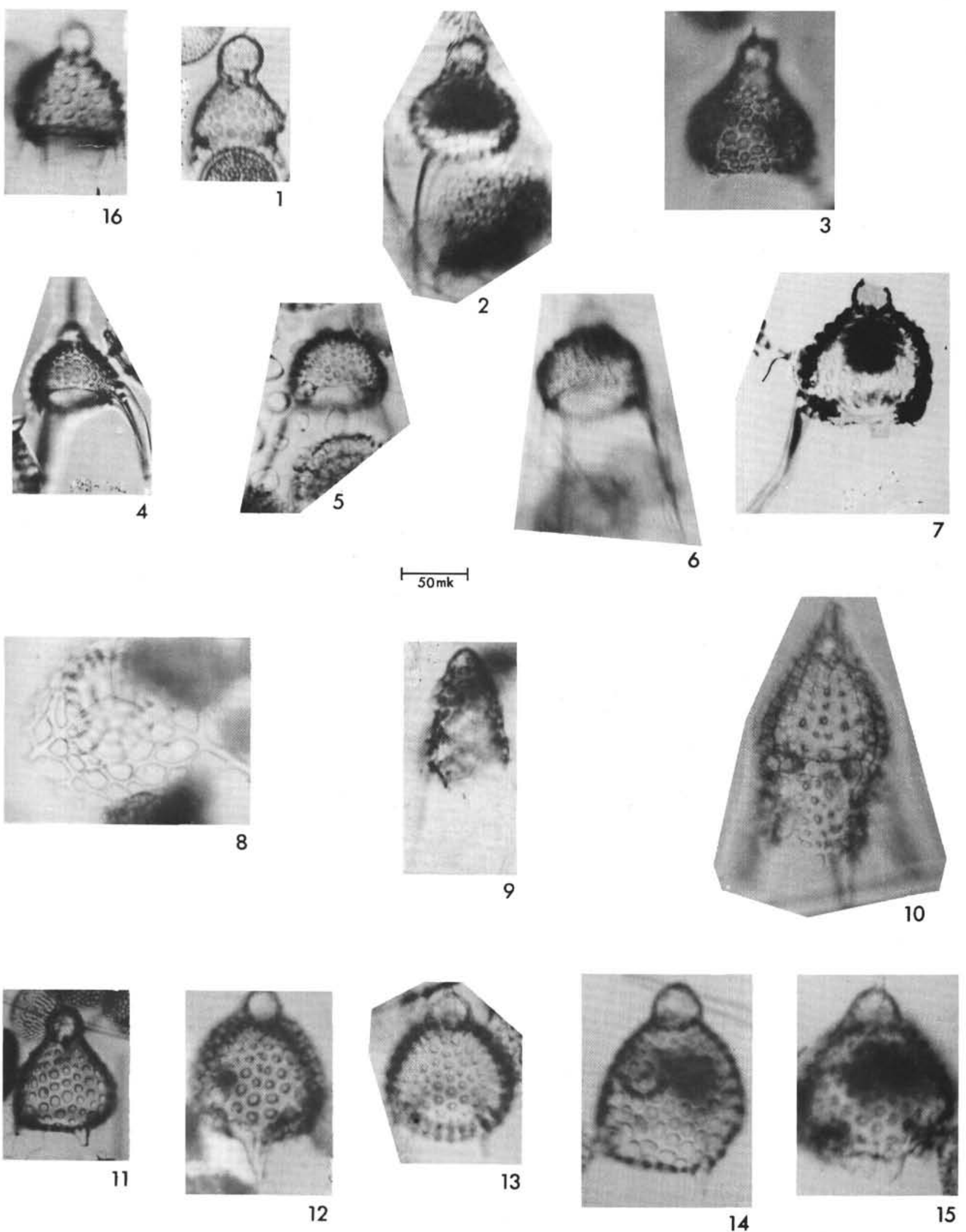
PLATE 13

Figures 1-19, 22, 23, 28-33, $\times 200$; Figures 24-26, $\times 180$;

Figures $20,21,27, \times 250$

Figures 1, 2 Cystophormis ob n. sp.

1. 29-278-12-2.

2. 29-278-12-5; Holotype.

Figures 3-7 Cystophormis brevispina (Vinassa).

3. $O b$ Station 268, $113-115 \mathrm{~cm}$.

4. 29-278-33-4.

5. $29-278-32-2$.

6, 7. 29-278-32-1.

Figure $8 \quad$ Botryocylinder sp. 14-144-2-2; Paleocene.

Figures 9, $10 \quad$ Botryometra poljanskii n. sp.

9. 29-278-12-1.

10. 29-278-12-3; Holotype.

Figure 11 Botryometra spongea n. sp. 29-278-37-3; Holotype.

Figure $12 \quad$ Centrobotrys sp. 29-278-12-3.

Figure 13 Tricolocapsa papillosa (Ehrenberg) group. Malago Mudstone, California.

Figure 14 Tricolocapsa bergontiana (Carnevale) 29-278-33-2.

Figure $15 \quad$ Botryopyle? sp. 29-278-12-3.

Figure 16 Botryocella ? appenninica Vinassa group. 29-27812-3.

Figure $17 \quad$ Botryocella $?$ sp. K, 29-281-16-3.

Figure 18 Botryopyle ? dionisi n. sp. 29-278-28-5; Holotype.

Figures 19, 20 Saccospyris preantarctica $\mathrm{n}$. sp.

19. $29-278$.

20. $O b$ Station 117, $275 \mathrm{~cm}$; Holotype.

Figure $21 \quad$ Saccospyris antarctica Haecker. Ob Station 207, $354 \mathrm{~cm}$.

Figure $22 \quad$ Botryopyle sp. A, 29-278-12-2.

Figure 23 Lithocorythium sp. 29-278-30-2.

Figures 24, 25 Botryocampe inflata Bailey group. Ob Station 256, $630 \mathrm{~cm}$.

Figures 26, 27 Botryocampe conithorax (Petrushevskaya) group. 26. $O b$ Station $256,730 \mathrm{~cm}$.

27. $O b$ Station $117,273 \mathrm{~cm}$.

Figure 28 Saccospyris antarctica Haecker. Ob Station 207, $354 \mathrm{~cm}$.

Figure 29 Peripyramis circumtexta Hck. group. 29-281-16-4.

Figures 30, 31 Peripyramis sp. 29-271-16-4.

Figures 32, 33 Cornutella profunda Ehrenberg group. 29-278-12- 
PLATE 13

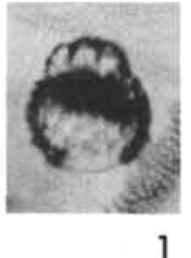

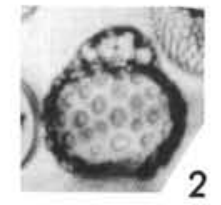

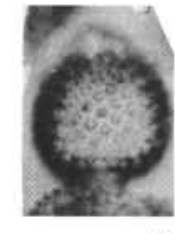

3
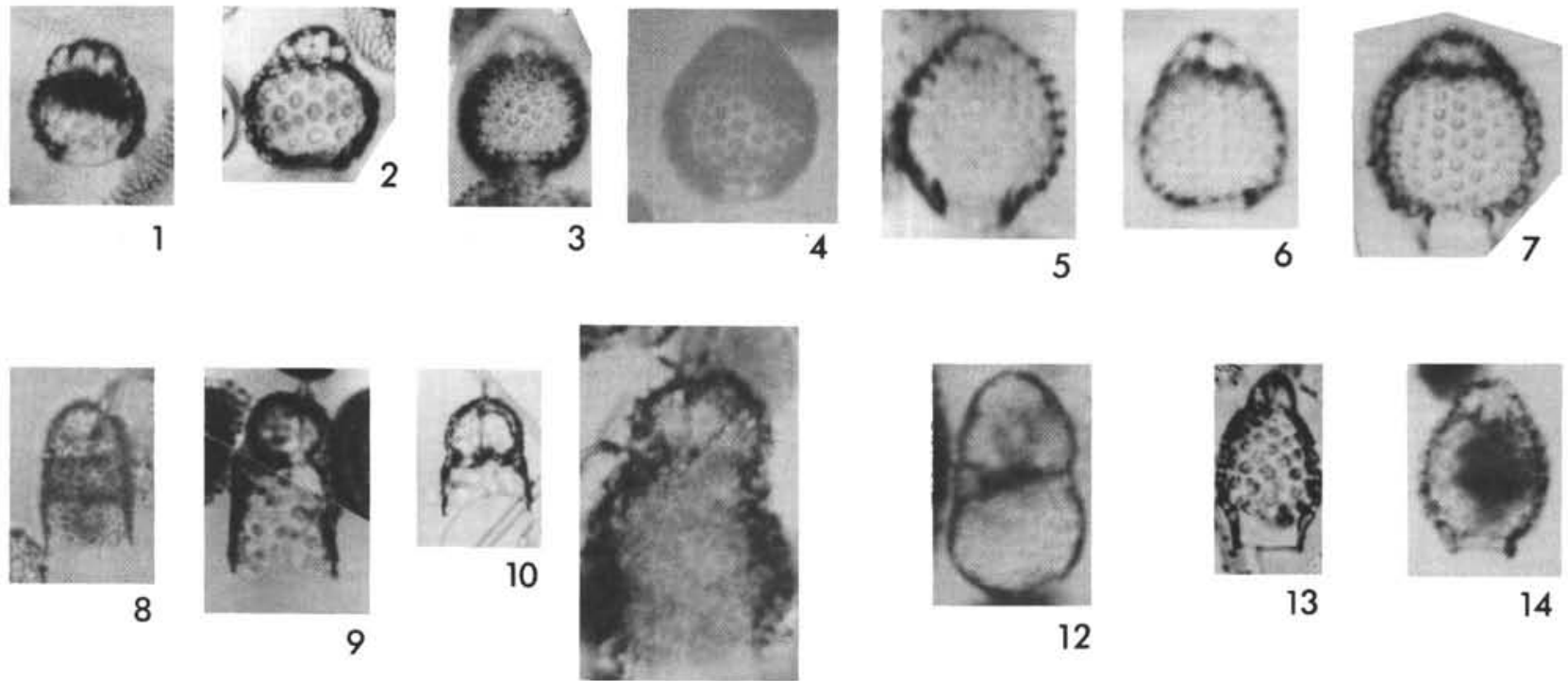

11
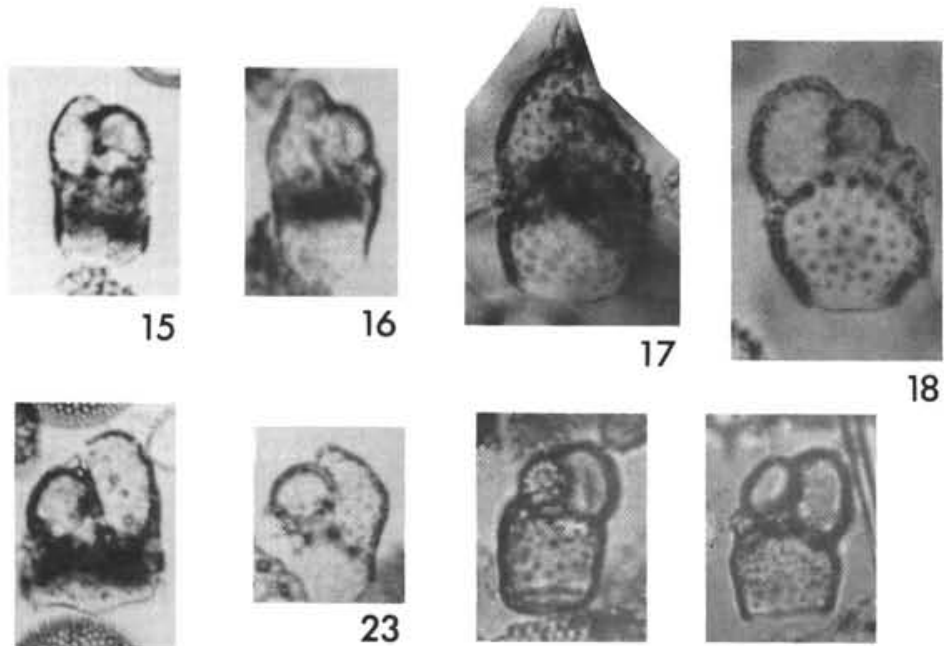

22
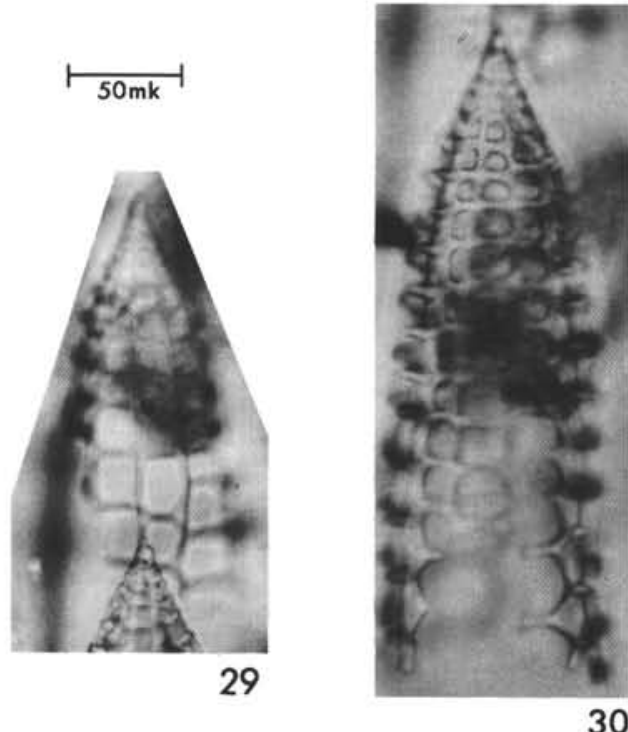

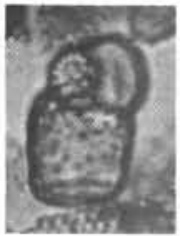

24
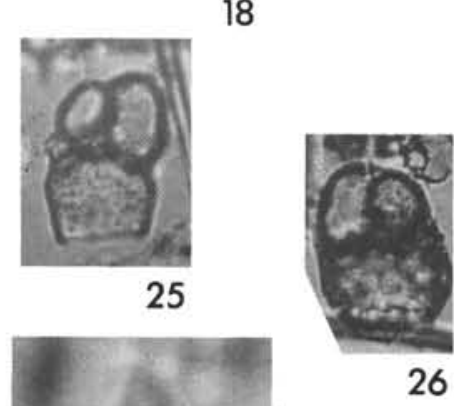

26
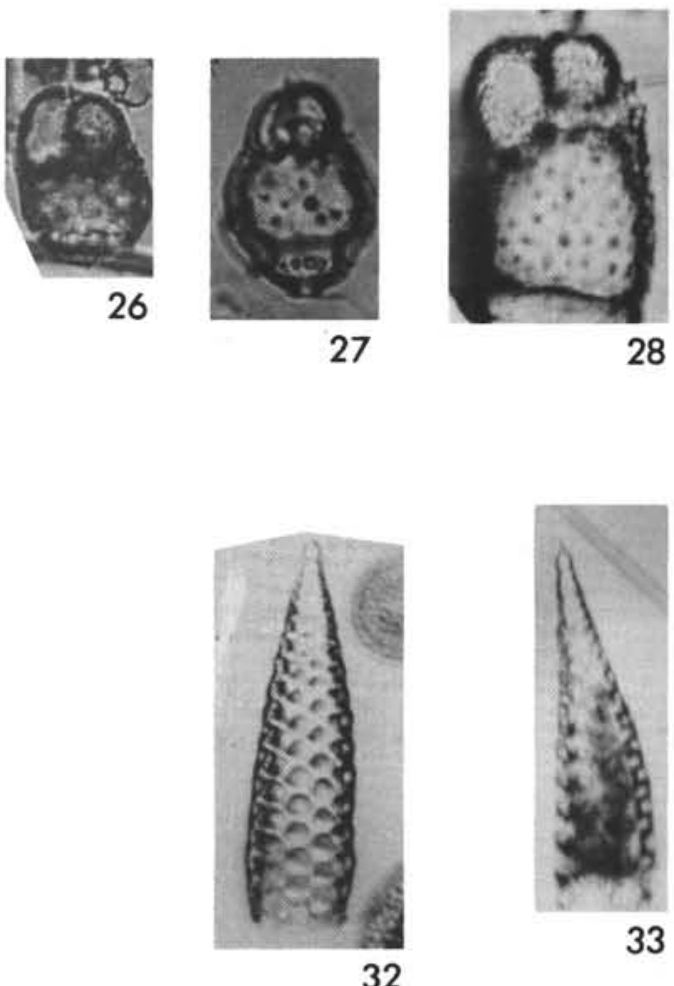
PLATE 14

Figures 1, 15-17, $\times 250$; Figures $2-11,19-30, \times 200$;

Figures $12-14,18, \times 180$

Figures 1, 2 Lithostrobus? clava (Ehrenberg). 14-144-2-2, bottom; Paleocene.

Figures 3, 4 Cyrtolagena laguncula Haeckel.

3. $29-278-12-6$.

4. $29-278-12-2$.

Figure $5 \quad$ Clathrocyclas sp. aff. C. nova Clark and Campbell. 14-144-2-2, bottom; Paleocene.

Figures 6-9 Lithocampe subligata Stöhr group.

6, 8. 29-281-6, CC.

7. 14-144B-2-6, top; Oligocene.

9. $\mathrm{Ob}$ Station $256,768-770 \mathrm{~cm}$.

Figure $10 \quad$ Lithocampe punctata (Stöhr). Ob Station 268, 113$115 \mathrm{~cm}$.

Figure 11 Thocorys longithorax n. sp. 29-178-33-1.

Figure 12 Lithocampe subligata Stöhr group. Ob Station 256, $770 \mathrm{~cm}$.

Figure 13 Lithocampe punctata (Stöhr) group. Ob Station $256,770 \mathrm{~cm}$.

Figures 14, 15 Lithocampe (Cyrtocapsella) cylindroides Principi. Ob Station 256, $770 \mathrm{~cm}$.

Figure 16 Stichocorys peregrinus (Riedel). Ob Station 256, $560 \mathrm{~cm}$.

Figures 17, 18 Lithocampe (Cyrtocapsella) japonica (Nakaseko). Ob Station 256, $768 \mathrm{~cm}$.

Figure 19 Stichopodium sp. 29-278-12-2.

Figure 20 Eucyrtidium sp. M 29-280A-5-6.

Figures 21, 22 Eucyrtidium sp. A; 29-281-16-3.

Figures 23, 24 Lithocampe (Cyrtocapsella) spp. 29-278-12-1.

23. Form B.

24. Form A.

Figures 25-27 Stichopodium biconica (Vinassa)

25. $O b$ Station $268,115-113 \mathrm{~cm}$.

26. $\mathrm{Ob}$ Station $256,583-585 \mathrm{~cm}$.

27. 29-281-6, CC.

Figure 28 Eucyrtidium acuminatum (Ehrenberg) group. 29278-12-2.

Figure 29 Stichopodium calvertense (Martin). 29-278-142.

Figure $30 \quad$ Stichopodium saccoi (Vinassa) 14-140-23, 80-84 $\mathrm{cm}$. 


\section{PLATE 14}
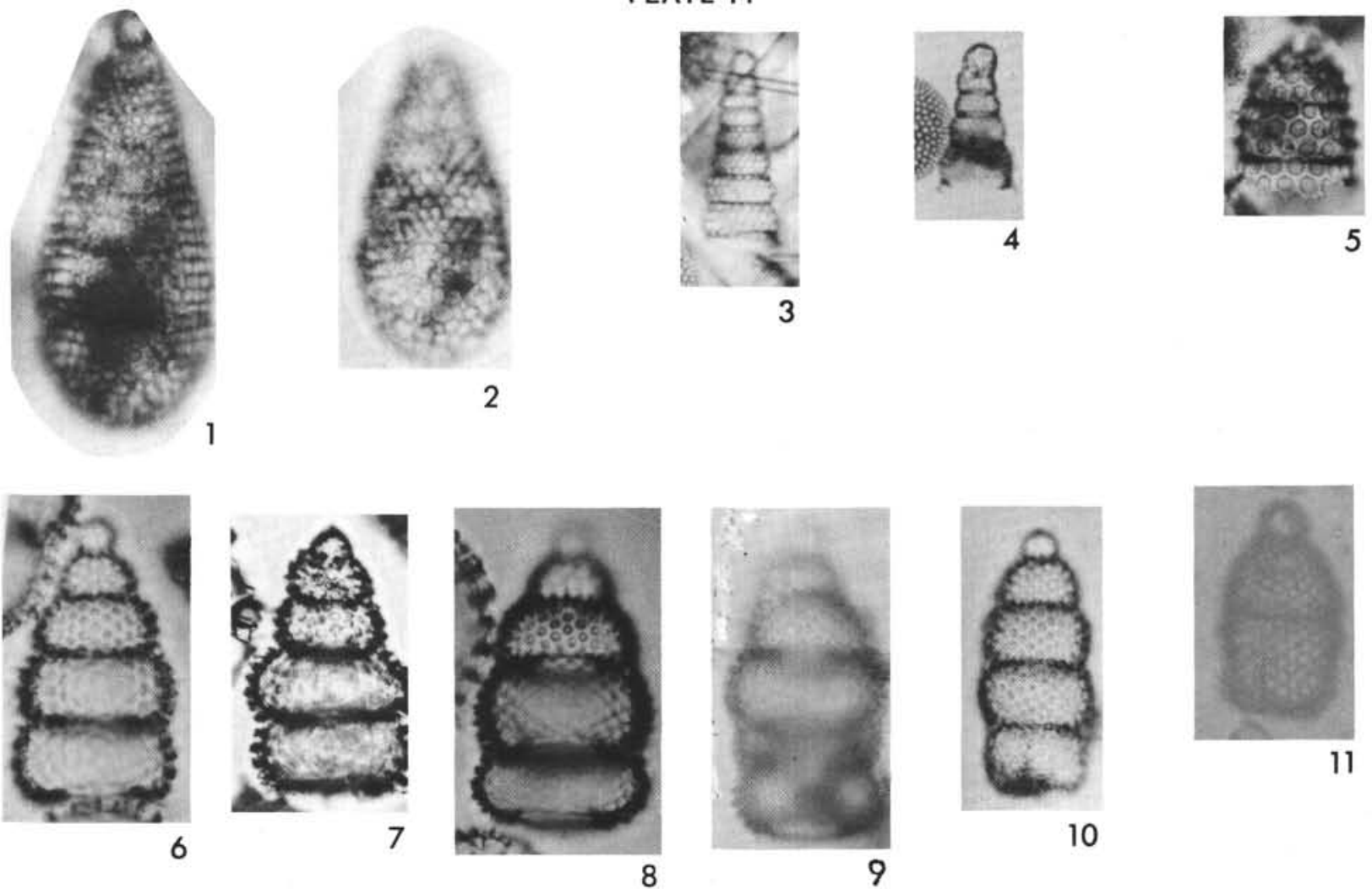

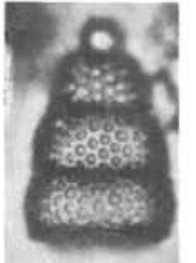

12

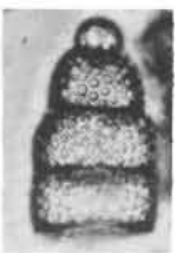

13
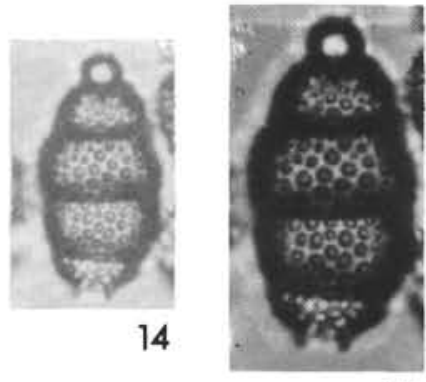

15
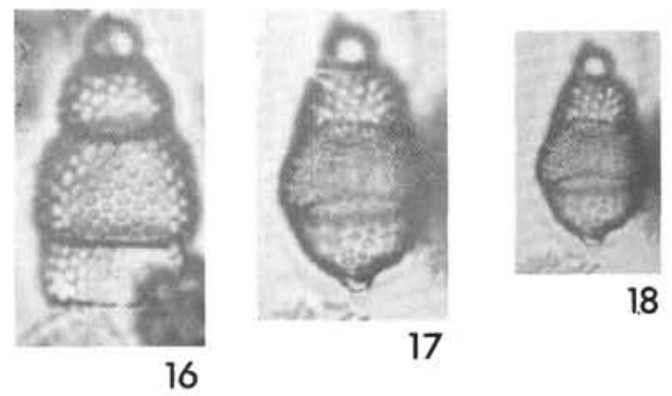

18
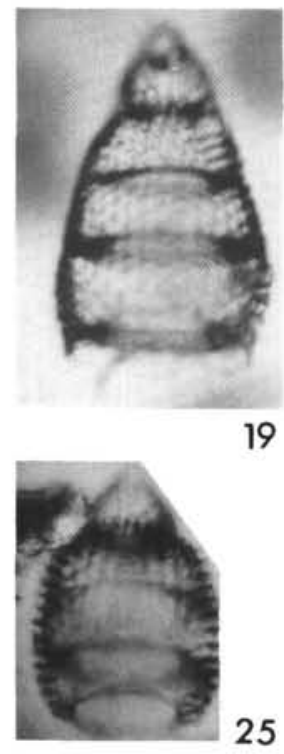
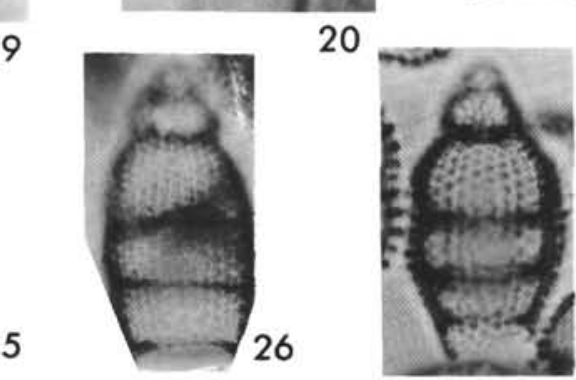

27
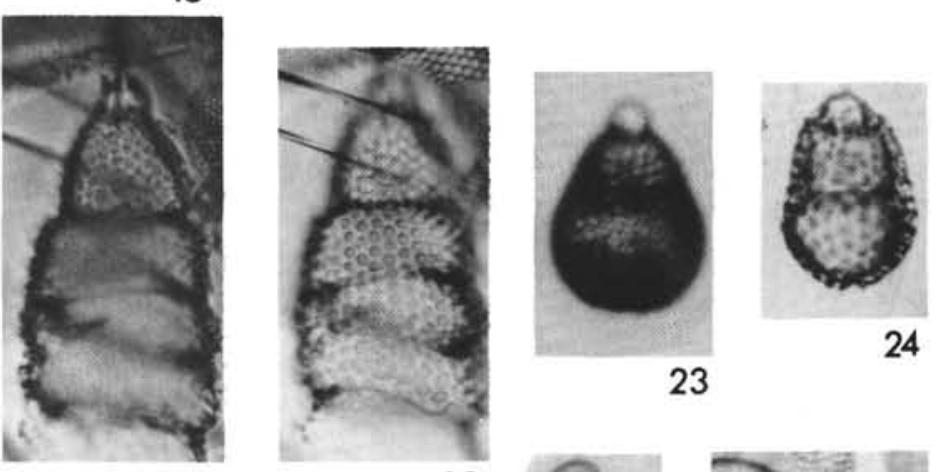

21
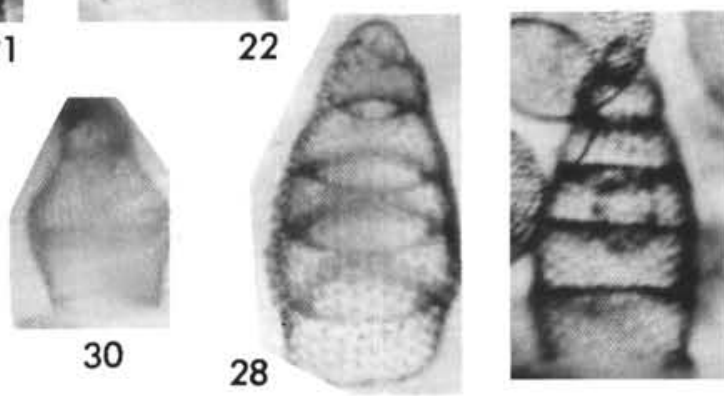
PLATE 15

Figures 1-5, 7-14, 18-23, 27-29, $\times 200$; Figure $6, \times 180$;

Figures $15-17,24-26, \times 250$

Figure 1 Sticholipidium sp. P. 14-144-2-2, bottom; Paleocene.

Figure 2 Anthocyrtella sp. A. 29-278-12-1.

Figure 3 Stichopilidium sp. 14-144-2-2, bottom; Paleocene.

Figures 4, $5 \quad$ Anthocyrtella sp. 29-278-12-1.

Figure $6 \quad$ Anthocyrtella spatiosa (Ehrenberg) group. 14-1442-2, bottom; Paleocene.

Figure $7 \quad$ Clathrocyclas humerus n. sp. 29-278-12-1; "sh" = "shoulders".

Figures 8-10 Diplocyclas bicorona Haeckel group.

8. 29-278-12-5.

9, 10. $29-278-12-1$.

Figure 11 Diplocyclas ionis (Haeckel) group.

Figure 12 Clathrocyclas bicornis (Popofsky) group. Malago Mudstone, California.

Figures 13, 14 Clathrocyclas universa Clark and Campbell group. 13. Western Siberian Eocene.

14. Californian Eocene.

Figures 15, 16 Clathrocyclas universa (?) group. 14-1442-2; Paleocene.

Figure $17 \quad$ Clathrocyclas ? sp. aff. C. universa nova Clark and Campbell 14-144-2-2; Paleocene.

Figures 18-20 Clathrocyclas sp. aff. C. humerus. 14-144-2-2, bottom; Paleocene.

Figure $21 \quad$ Clathrocyclas titanothericeraos. 29-278-12-1.

Figures 22, 23 Clathrocyclas humerus n. sp.

22. 29-278-12-1; Holotype.

23. 29-281-6, CC.

Figure 24 Clathrocyclas sp. aff. C. bicornis Hays. Ob Station $117,275 \mathrm{~cm}$.

Figure 25 Clathrocyclas bicornis Hays. Ob Station 212, 225 $\mathrm{cm}$.

Figure $26 \quad$ Clathrocyclas bicornis (Popofsky) group.

Figures 27-29 Clathrocyclas cabrilloensis Campbell and Clark group.

27, 29. Same specimen 29-278-122.

28. 29-278-12-1. 
PLATE 15
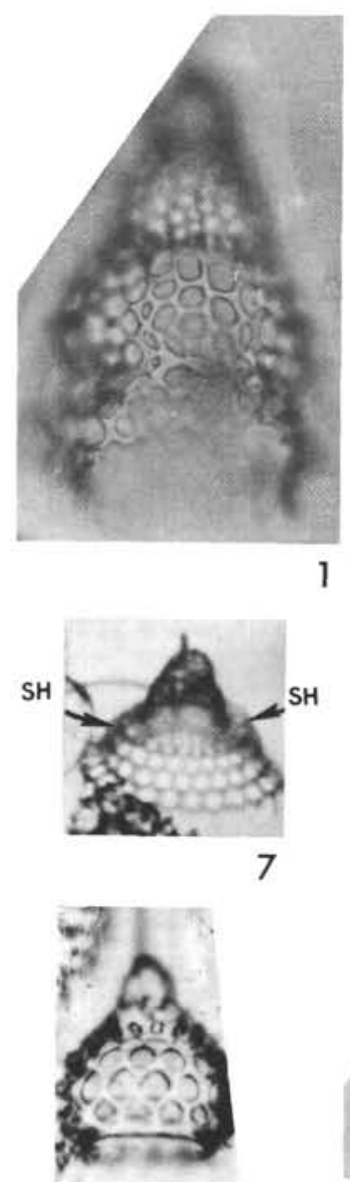

13
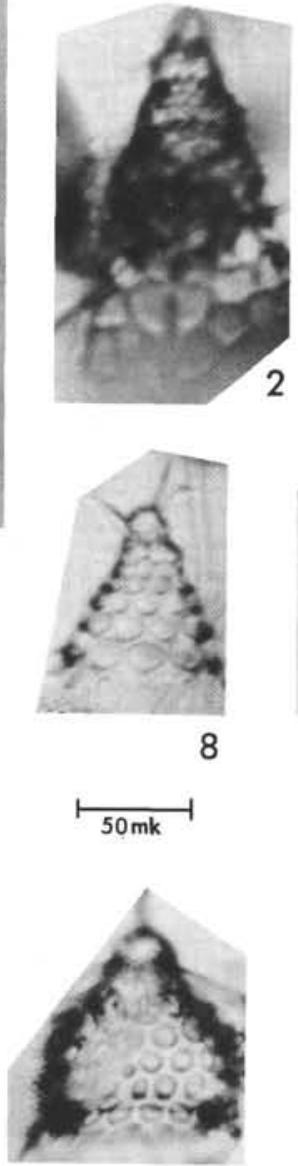

14
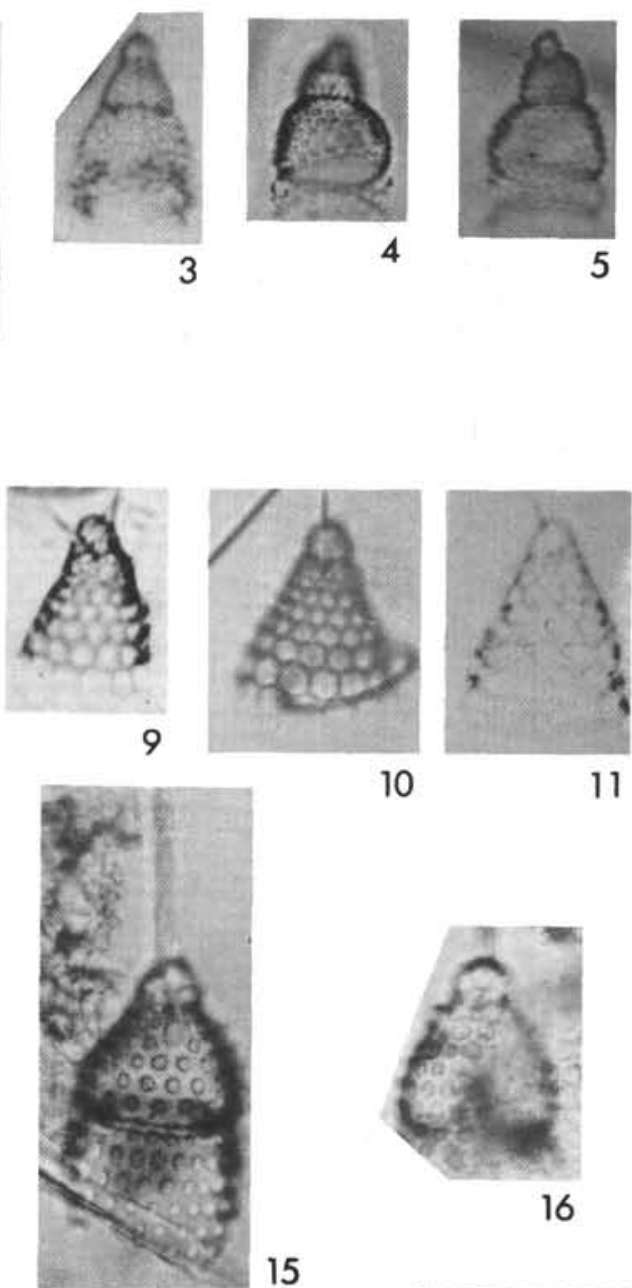

10
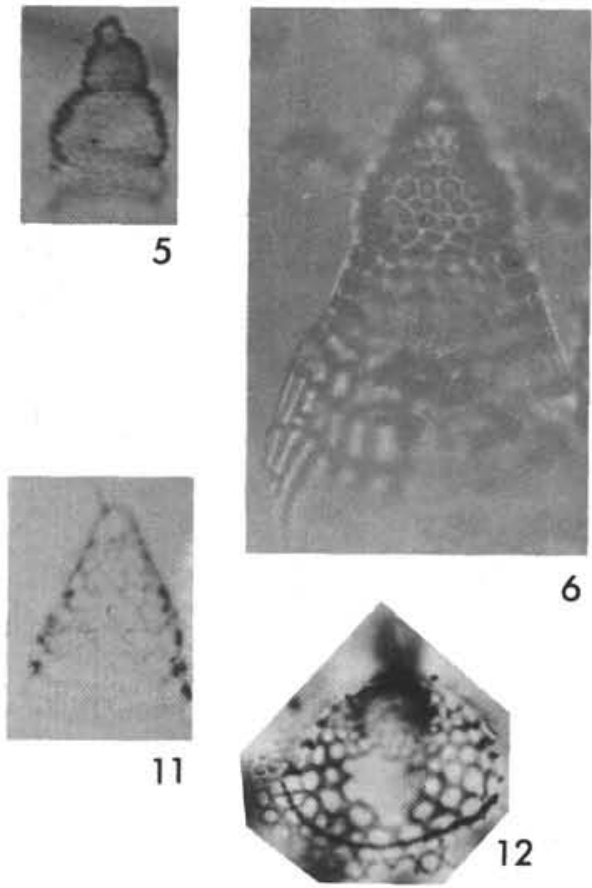

15
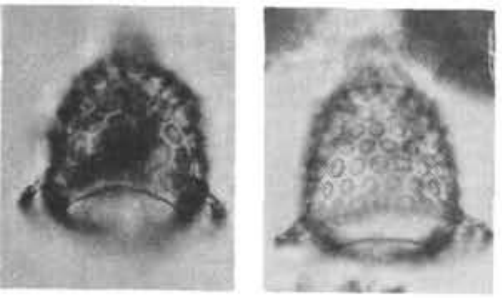

19
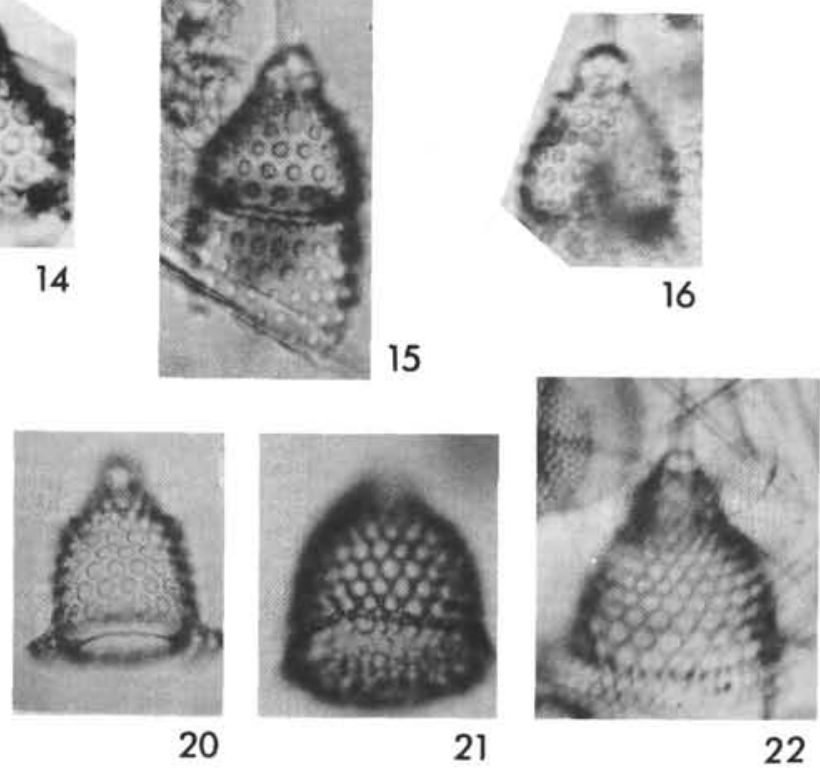

22
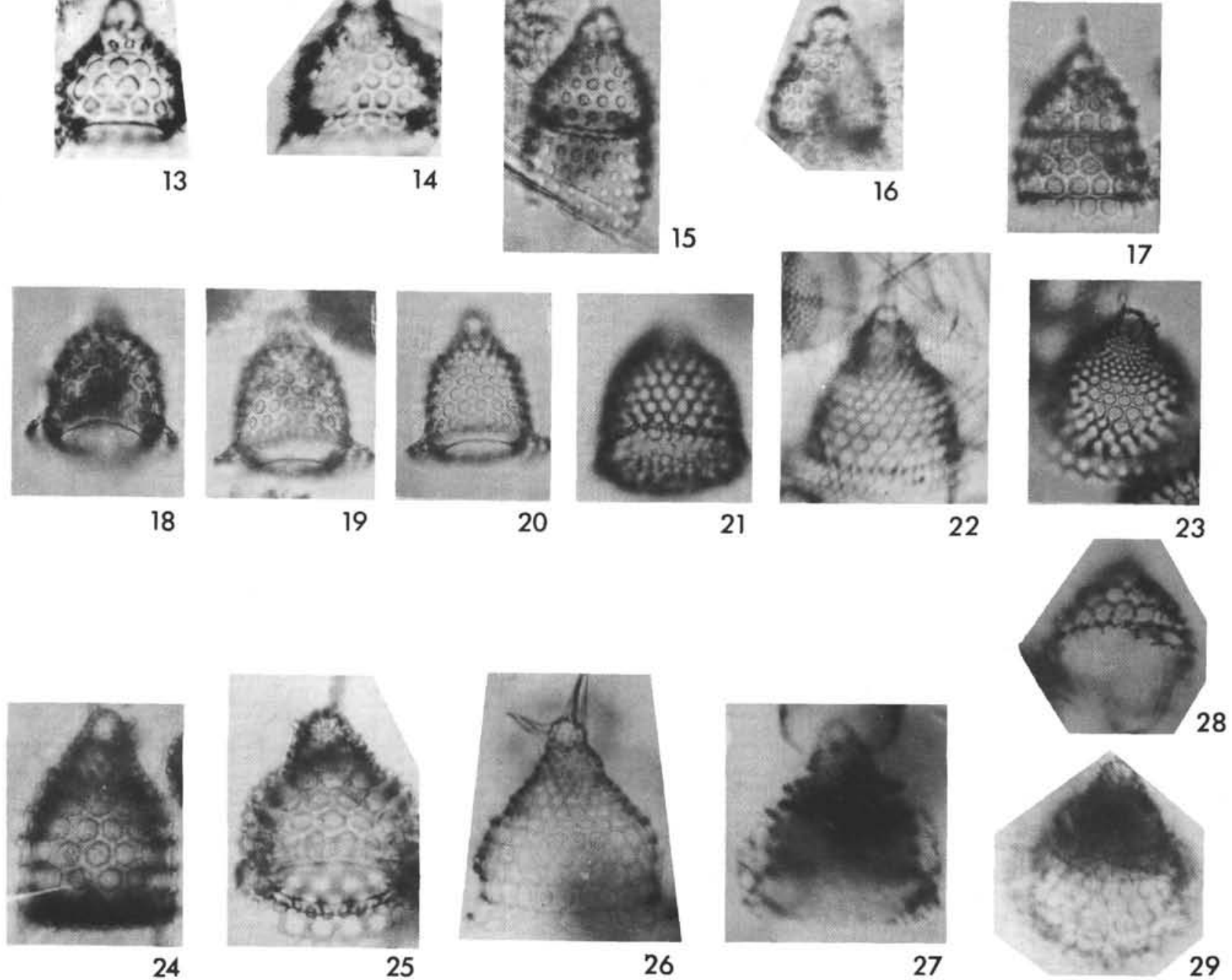

25

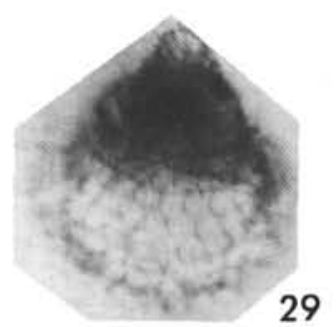


PLATE 16

Figures 1-6, 8, ×200; Figure 7, ×150; Figure 9, ×450

Figure 1-4 Lamprocyclas aegles Haeckel group. 29-281-6, CC.

Figure 5 Anthocyrtella sp. A. Ob Station 256, 1031-1033 $\mathrm{cm}$.

Figure $6 \quad$ Spirema sp. Kling.

Figure 7 Perichlamidium sp. Q. Ob Station 125, $200 \mathrm{~cm}$.

Figure $8 \quad$ Amphisphaera spinulosa (Ehrenberg) group. 14$138-2-3,5-7 \mathrm{~cm}$.

Figure $9 \quad$ Liosphaera antarctica Nakaseko. Ob Station 285; the internal macrosphere with tuberculae; radial spines 3-edged. 


\section{PLATE 16}
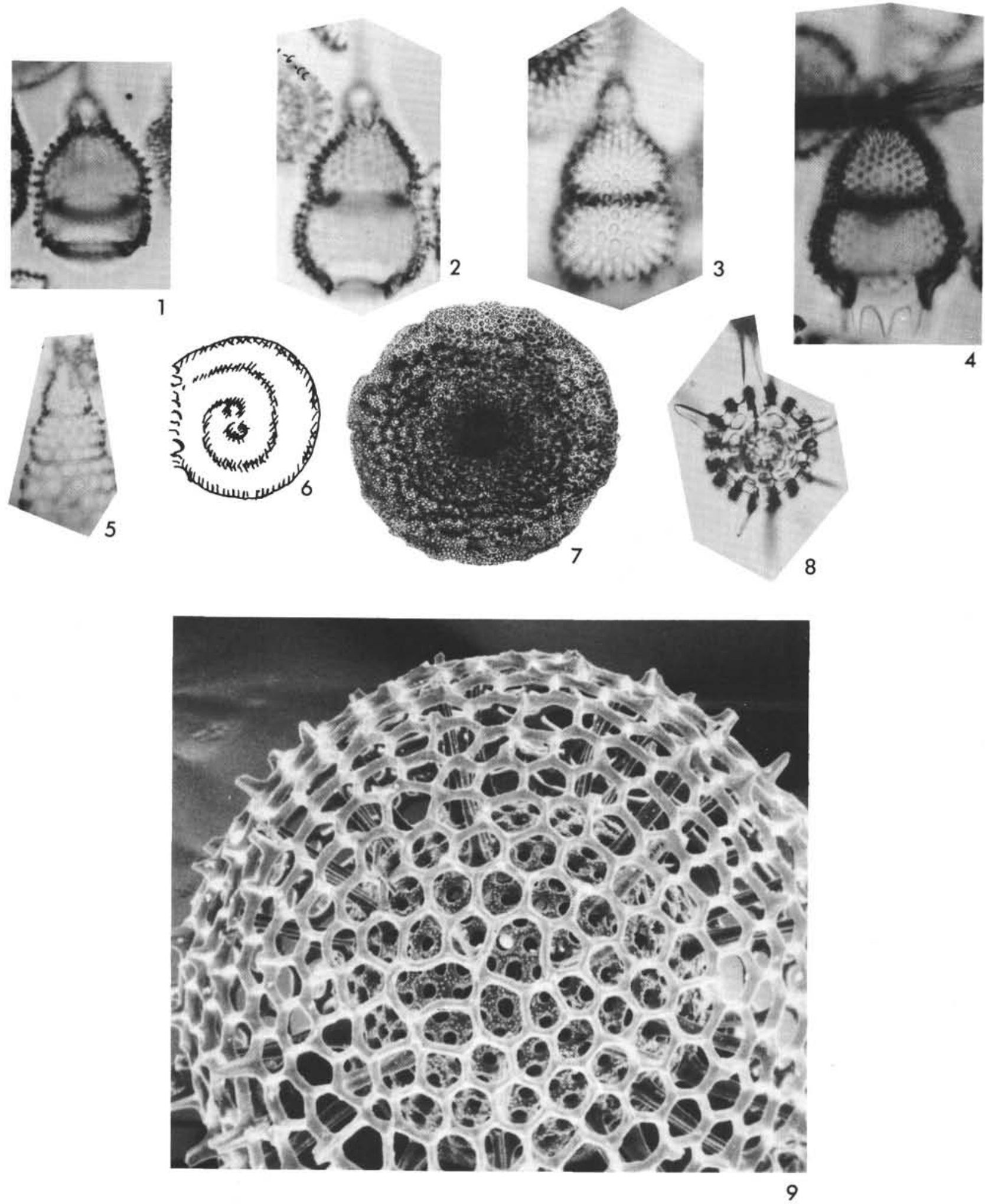


\section{PLATE 17}

All figures $\times 400$

Figure 1 Hexastyliidae gen. sp. indet. $O b$ Station 20; surface sediment.

Figure 2 Cenosphaera cristata Haeckel. Ob Station 22; surface sediment.

Figure $3 \quad$ Lonchosphaera sp. A. Ob Station 20; surface sediment. The central part of the shell is broken.

Figures 4-8 Lonchosphaera spicata Popofsky.

4. $O b$ Station 29; surface sediment.

5. $O b$ Station 20; surface sediment.

6. Microspheres.

7. $O b$ Station 17; surface sediment.

8. The internal structure.

Figures 9, 10 Lonchosphaera sp. B., Ob Station 16.

Figures 11-15 Lonchosphaera sp. C.

11. $O b$ Station 29; surface sediment.

12. The microspheres.

13. $O b$ Station 17.

14. Vitjaz Station 3342

15. The microspheres.

Figure 16 Haliomma nobile Ehrenberg. Upper Oligocene; Barbados.

Figure 17 Sphaeroidea gen. sp. Russian European Eocene; Core 531 from the collection of S. Totshilina. The outer shell is similar to Cenosphaera megachile. 


\section{PLATE 17}

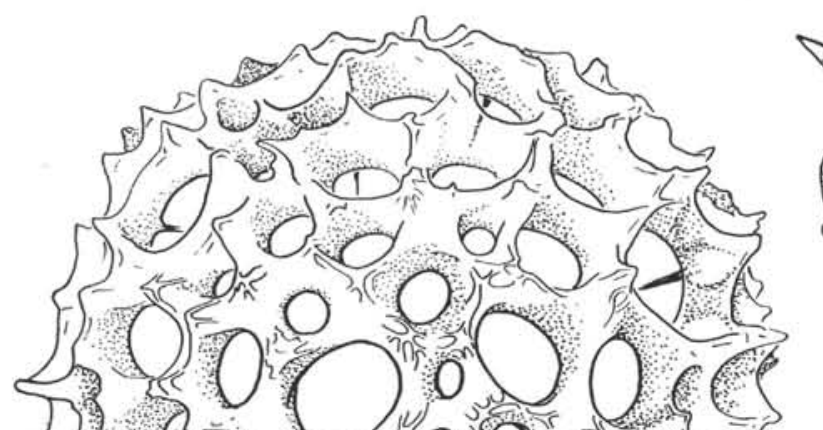

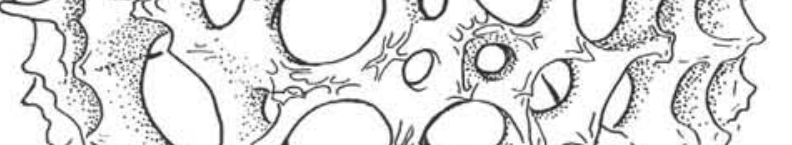

30.040 .00

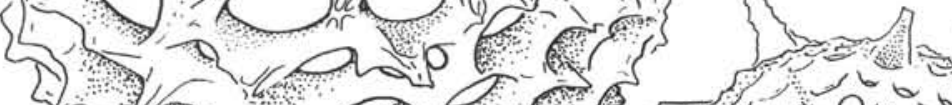
(1)
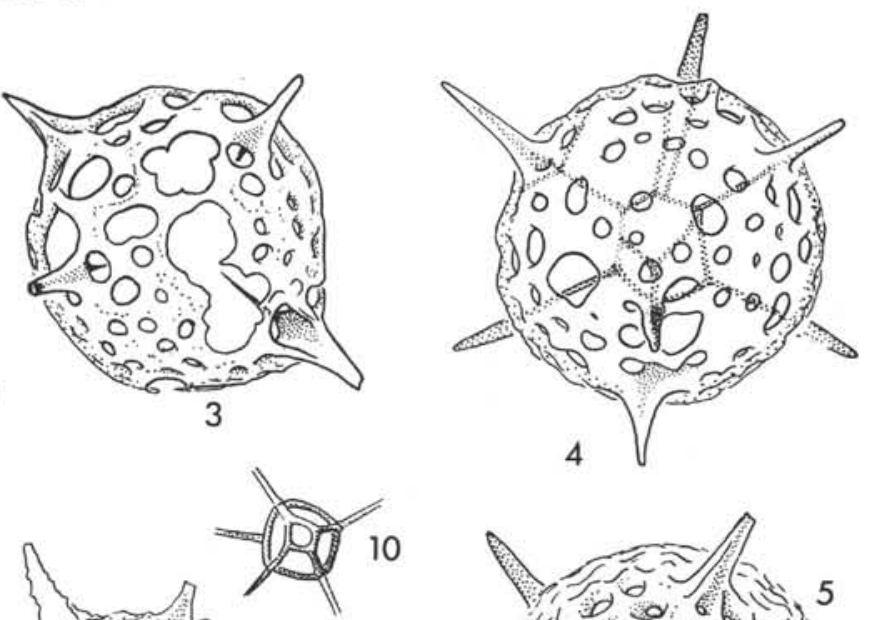

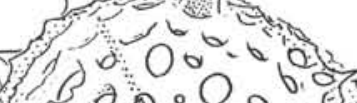

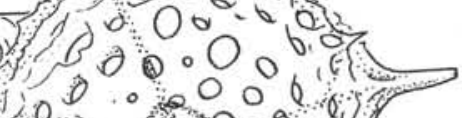

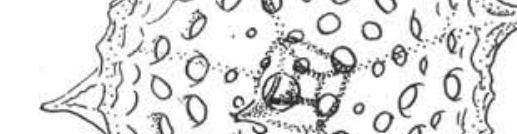
1
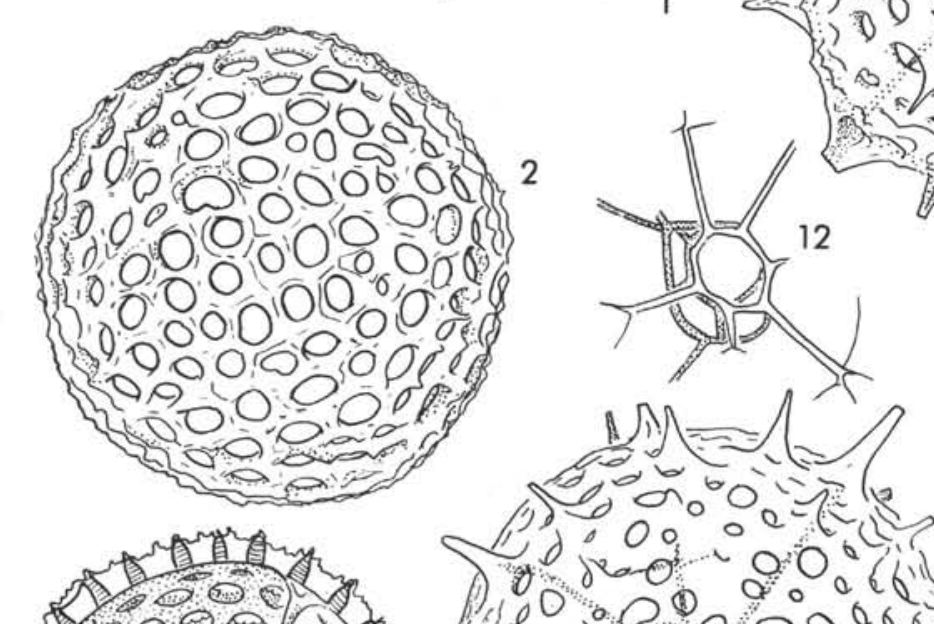

20
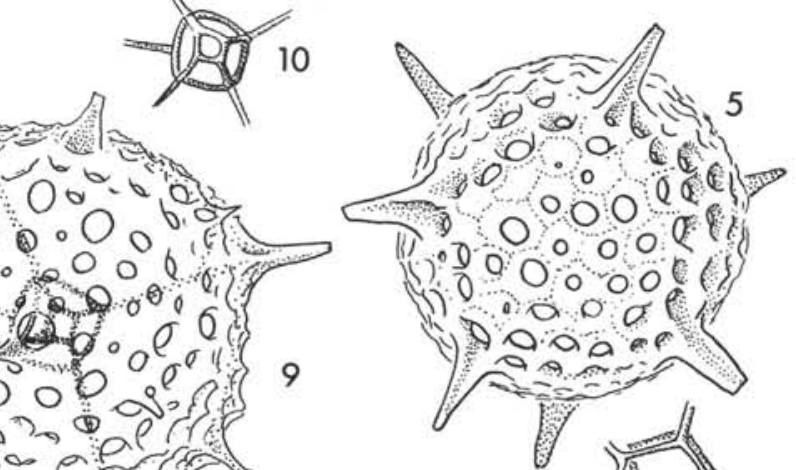

(ii) 0000000

(1) $00000 \%$

yologe
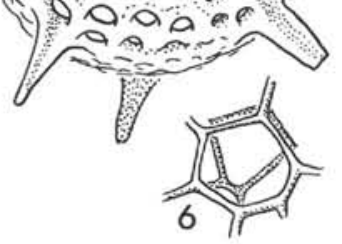

51000000

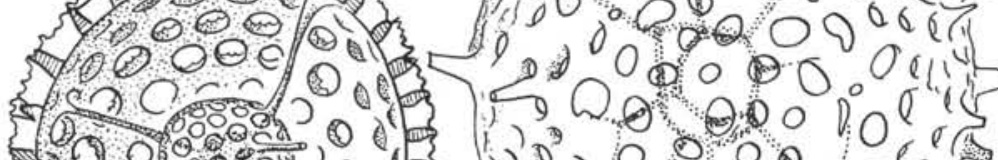

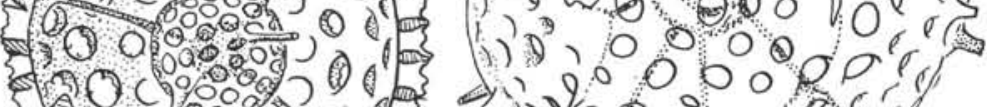
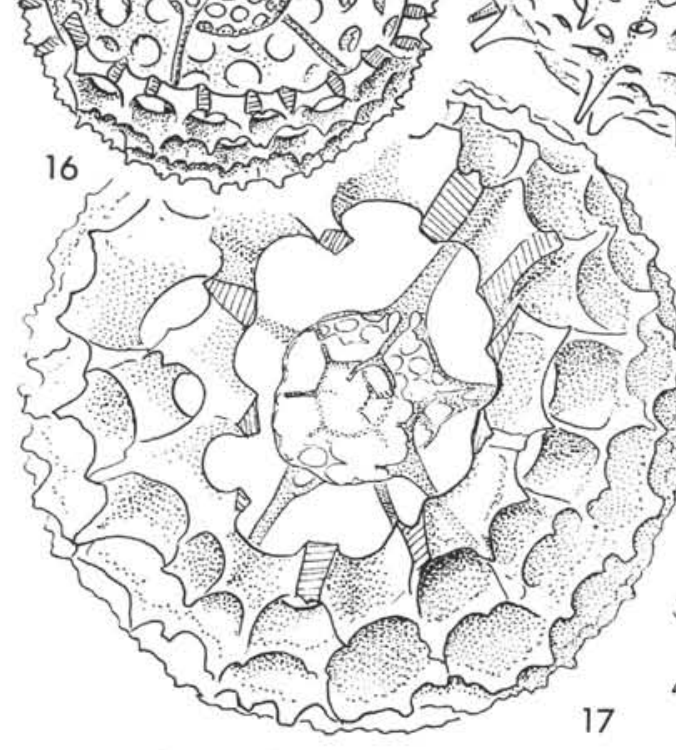

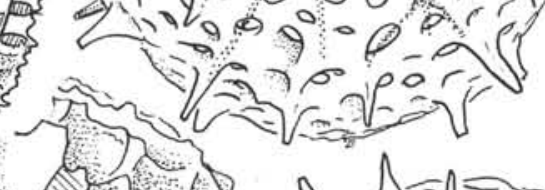

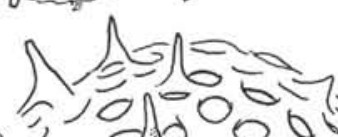
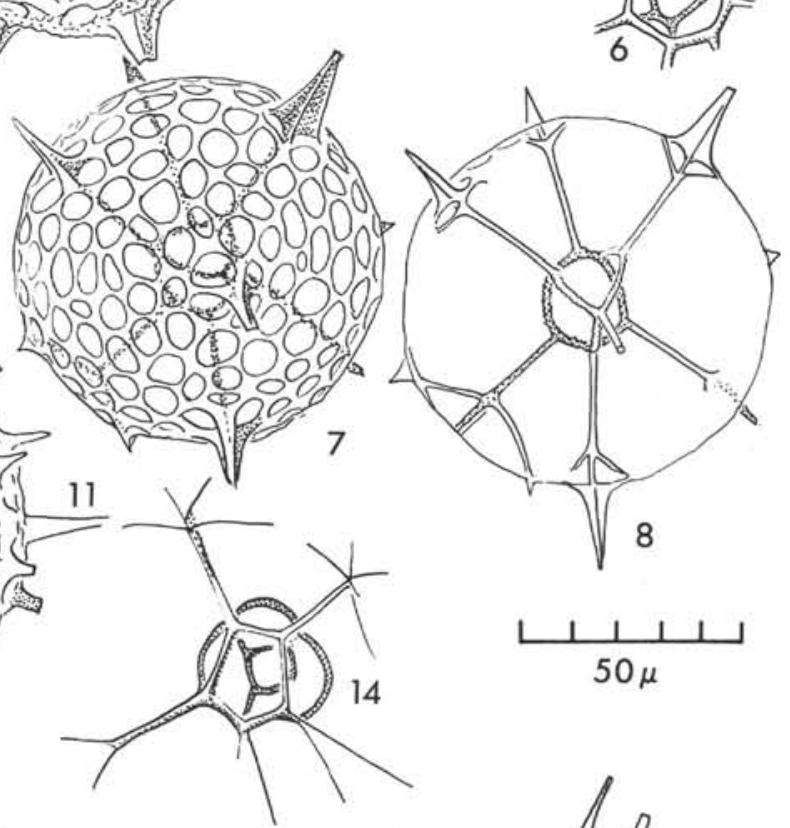

, 010000

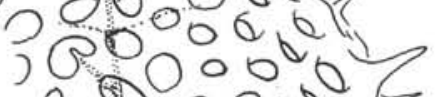

$000.0070^{\circ}$

O O O O O O

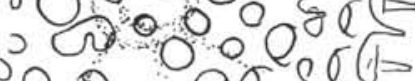

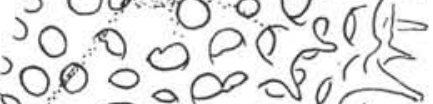

vin

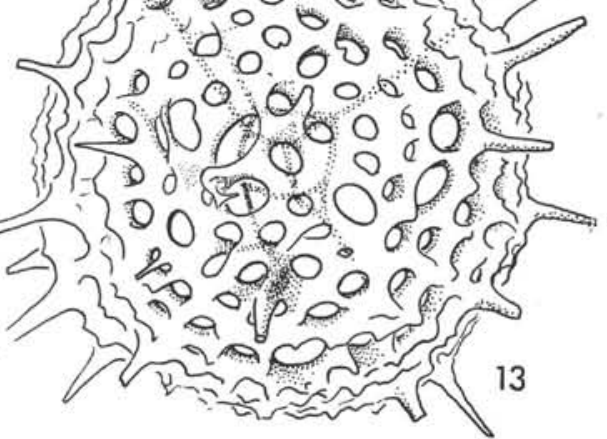




\section{PLATE 18}

Figures 1-4 Ceratocyrtis sp. "r" group.

1. Middle Tertiary form; 29-278-28-6, $40 \mathrm{~cm}$; side view.

2. Neogene form; $O b$ Station 8; surface sediment.

3. Neogene form; $O b$ Station 46; surface sediment.

4. Middle Tertiary form; 29-278-28-6, $40 \mathrm{~cm}$; front view.

Figure 5 Antarctissa strelkovi Petrush. Middle Miocene form; 29-278-22-3, $40 \mathrm{~cm}$.

Figure $6 \quad$ Antarctissa longa (Popofsky). Ob Station 16.

Figure $7 \quad$ Lithopera oceanica Ehrenberg. Ob Station 16; surface sediment.

Figures 8, 9 Antarctissa capitata group. Recent forms.

8. $\mathrm{Ob}$ Station 46; surface sediment.

9. $O b$ Station 44; surface sediment.

Figure 10 Lithopera oceanica Ehrenberg group. Ob Station 6; surface sediment. 
PLATE 18
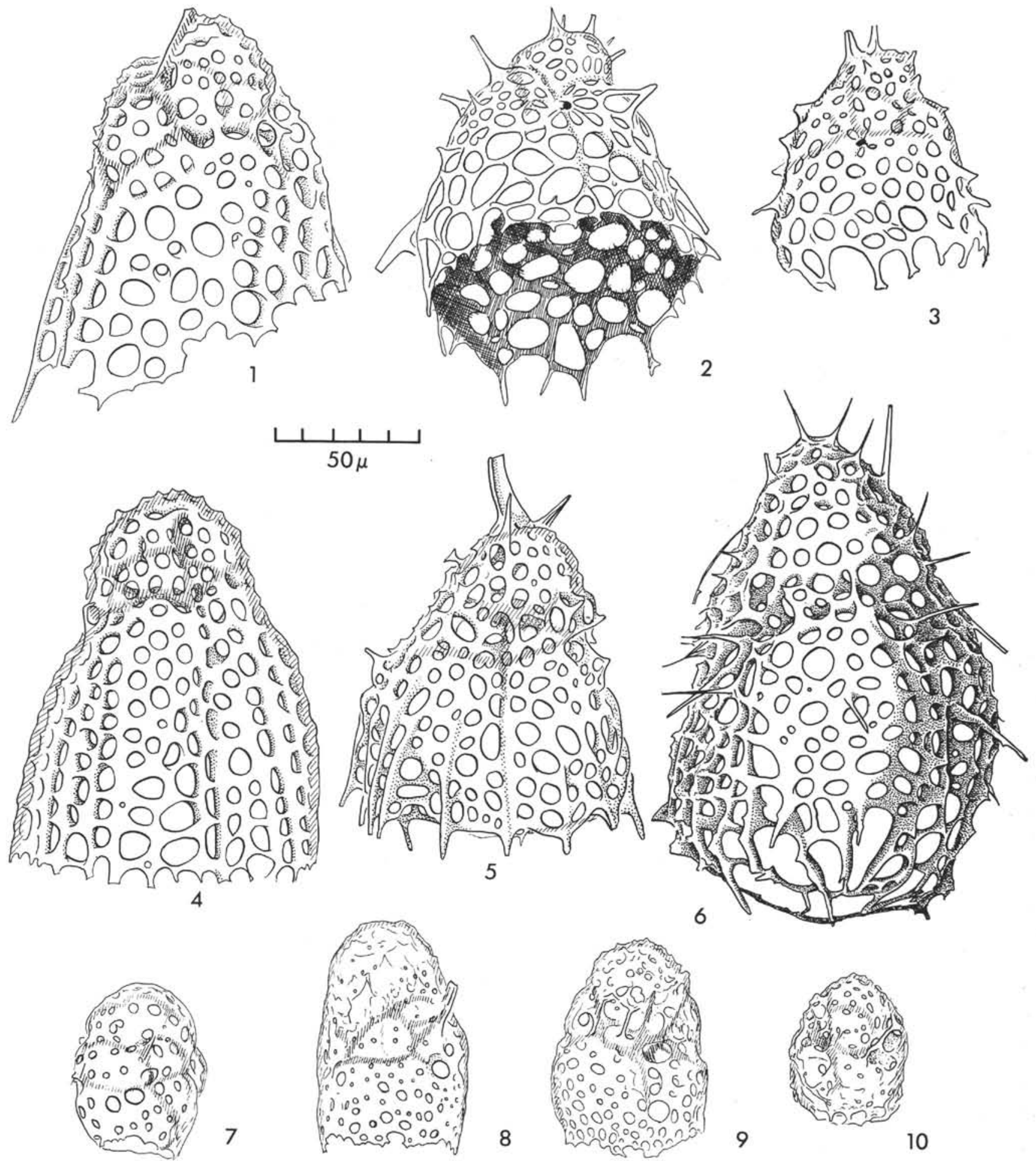


\section{PLATE 19}

Figure I Ceratocyrtis sp. "r". Recent (?) form, Ob Station 8 ; surface sediment; side view.

Figure 2 Ceratocyrtis amplus (Popofsky). typical; Ob Station 46; surface sediment.

Figure 3 Lithomelissa? hystrix Jörgensen. Sevastopol Station 1056, Norwegian Sea; surface sediment.

Figures 4, $5 \quad$ Lithopera oceanica Ehrenberg group. Surface sediment.

4. $O b$ Station 274.

5. $O b$ Station 291.

Figure 6 Antarctissa capitata (Popofsky) group. Ob Station 221; surface sediment. 
PLATE 19

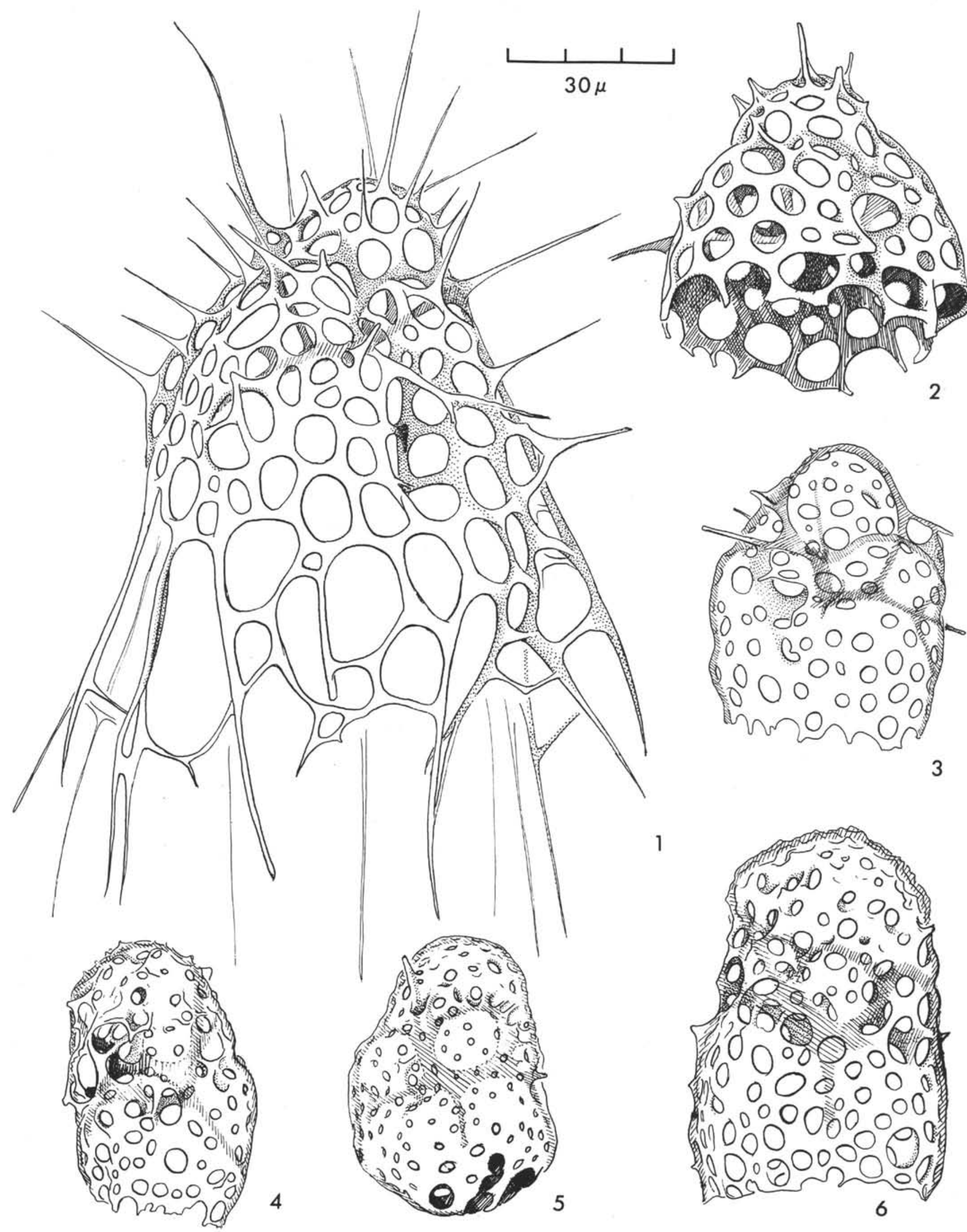


PLATE 20

All figures $\times 2000$

Figures 1, 2 Antarctissa capitata (Popofsky) group.

1. $O b$ Station 291; surface sediment.

2. $O b$ suspended material sample 61 ; surface plankton.

Figure 3 Botryopera laticeps (Jörgensen)? Sevastopol Station 1056; surface sediment.

Figure $4 \quad$ Botryopera triloba (Ehrenberg) group. Ob Station 291; surface sediment.

Figures 5, $6 \quad$ Botryopera (?) chlamida n. sp.

5. $\mathrm{Ob}$ Station 158

6. $O b$ Station 283; surface sediment; Holotype. 
PLATE 20
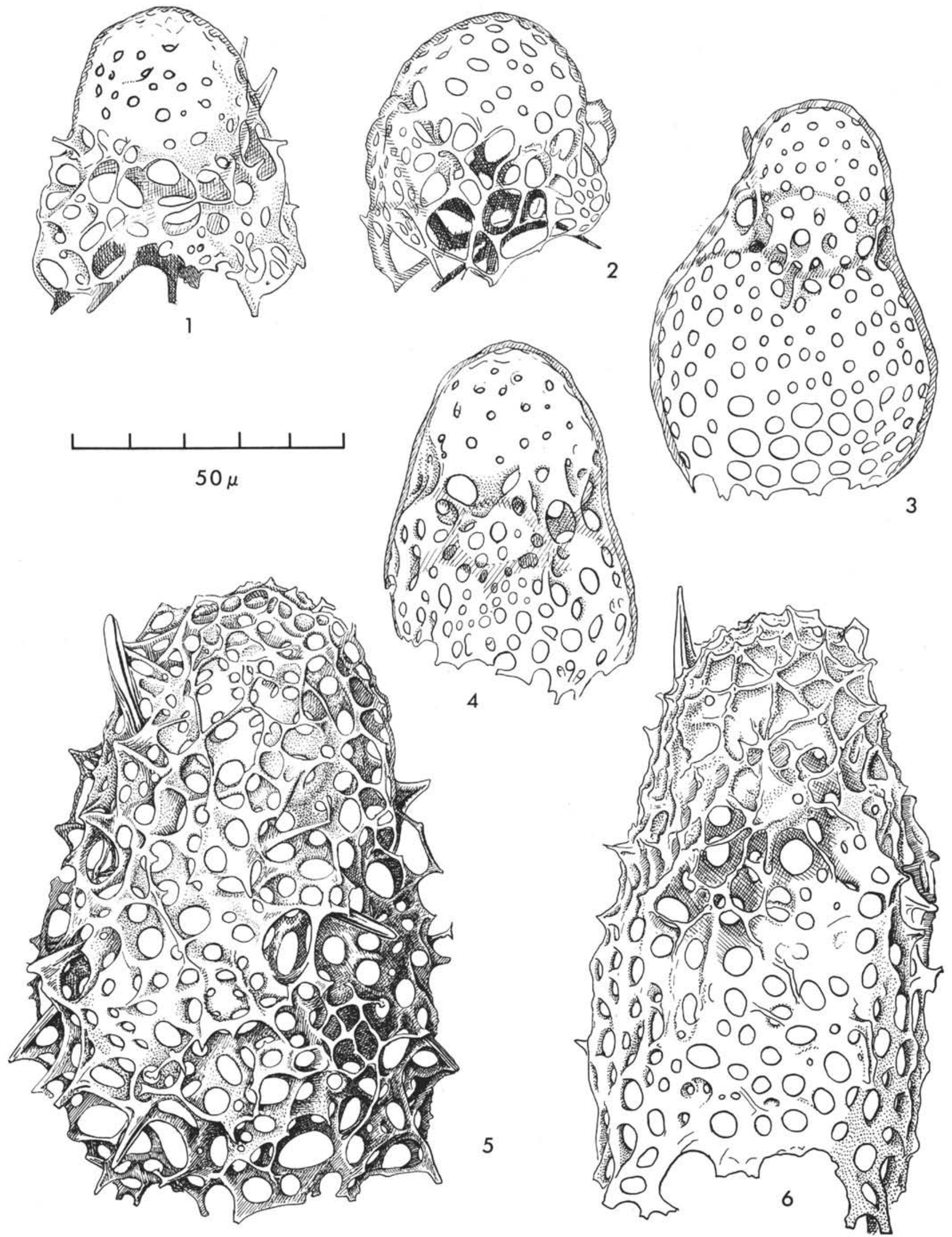
PLATE 21

Figure 1 Clathrocorona sphaerocephala (Haeckel) group. 139-7, CC.

Figure 2 Clathrocorona (?) sp. E. 29-280A-5-2, $25 \mathrm{~cm}$.

Figure 3 Gondwanaria hister n. sp. 29-278-21-3; Holotype.

Figures 4, 5 Gondwanaria japonica (Nakaseko) group. rather untypical form.

4. $29-278-28-5,40 \mathrm{~cm}$.

5. $29-278-28-3$.

Figure 6 Clathromitra ?sp. $O b$ Station; 34 surface sediment.

Figure 7 Botryometra poljanskii n. sp. 29-278-12-2, $40 \mathrm{~cm}$

Figure $8 \quad$ Corythomelissa sp. aff. Spongomelissa adunca Sanfilippo and Riedel. 29-278-33-1.

Figure 9 Corythomelissa horrida n. sp. $O b$ Station 25; surface sediment.

Figure 10 Calocyclas sp. K 29-278-12-1, $40 \mathrm{~cm}$; Rare specimen with abdomen.

Figure 11 Orbula sp. 29-278-28-5, $40 \mathrm{~cm}$.

Figure 12 Corythomelissa sp. aff. C. horrida. Ob Station 272; surface sediment. 


\section{PLATE 21}
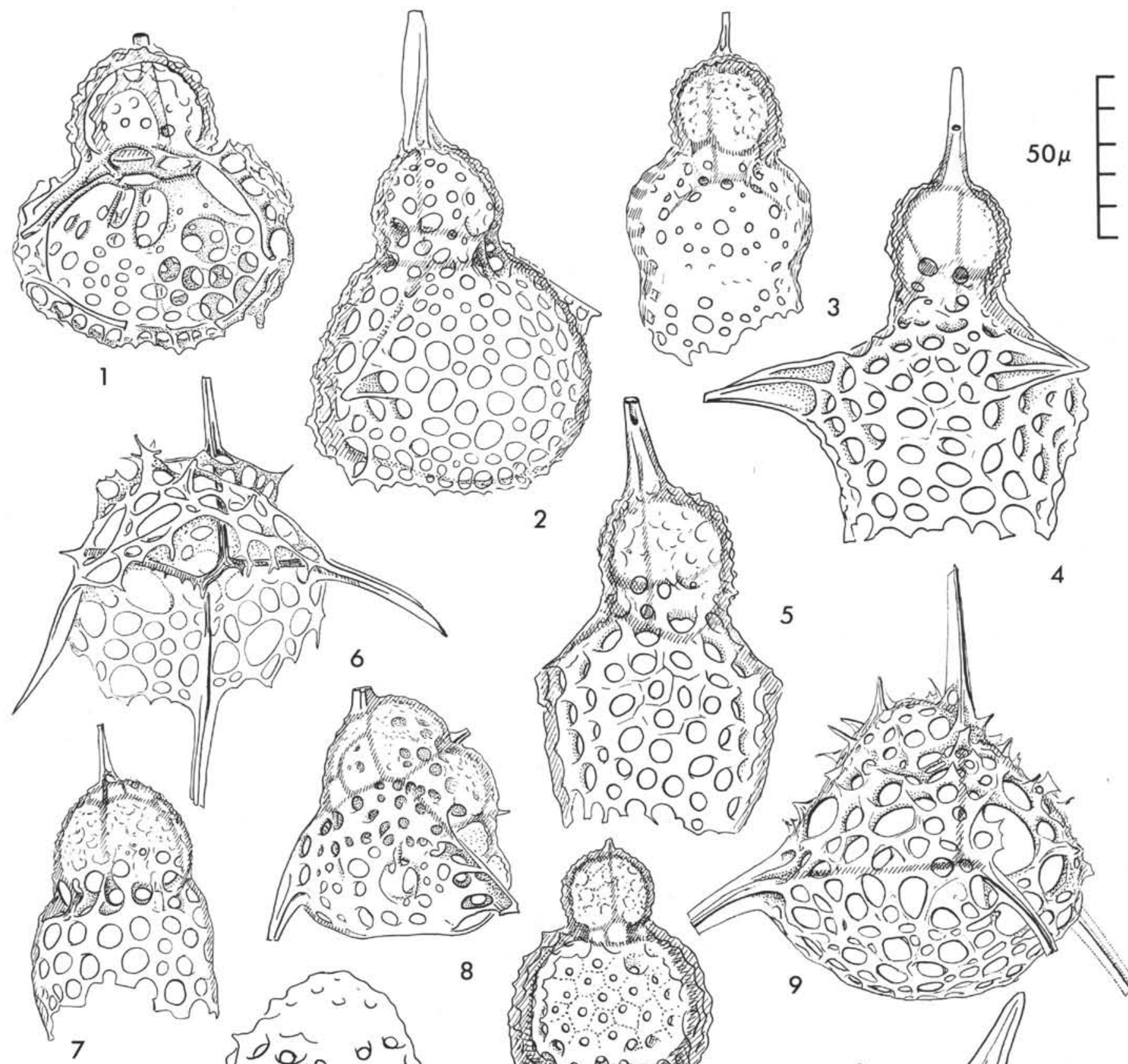

4
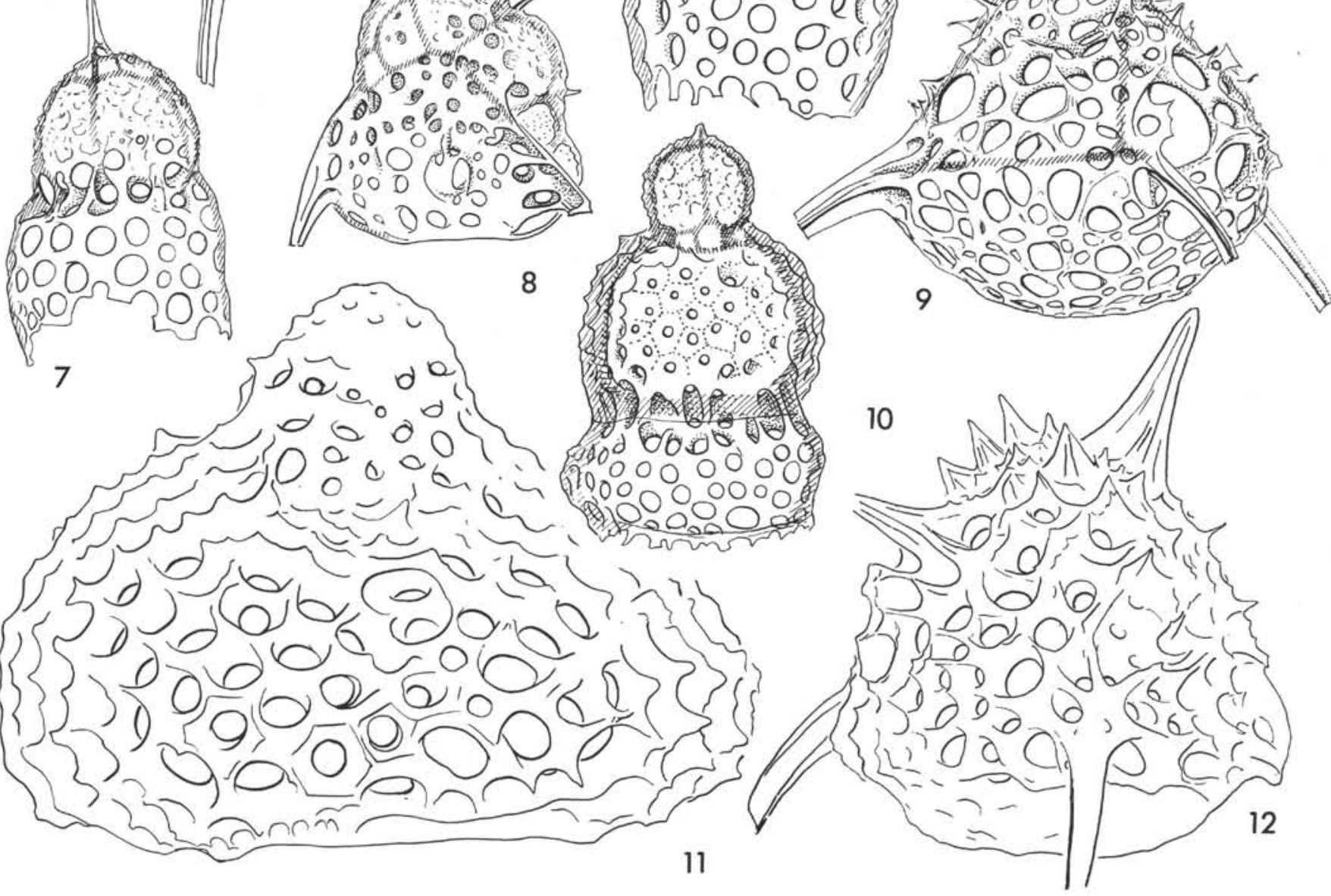


\section{PLATE 22}

Figure 1 Theocotyle robusta (Clark and Campbell). 29-27823-3.

Figure 2 Theocorys longithorax n. sp. 29-278-33-1.

Figure 3 Androcyclas sp. aff. Hamprocyclas heteroporus Hays. $O b$ Station 446; surface sediment.

Figure $4 \quad$ Stichopodium (?) sp. Ob Station 274; surface sediment.

Figure 5 Stichopodium $\mathrm{sp}$. aff. Eucyrtidium calvertense Martin. 29-278-20-3, $40 \mathrm{~cm}$; Middle Miocene.

Figure 6 Stichopodium sp. aff. Eucyrtidium calvertense Martin. $O b$ Station 125; 175-178 cm; Pleistocene; Bruhnes epoch.

Figure $7 \quad$ Stichopodium biconicum (Vinassa). Romanian Miocene; P. Dumitrica collection. 


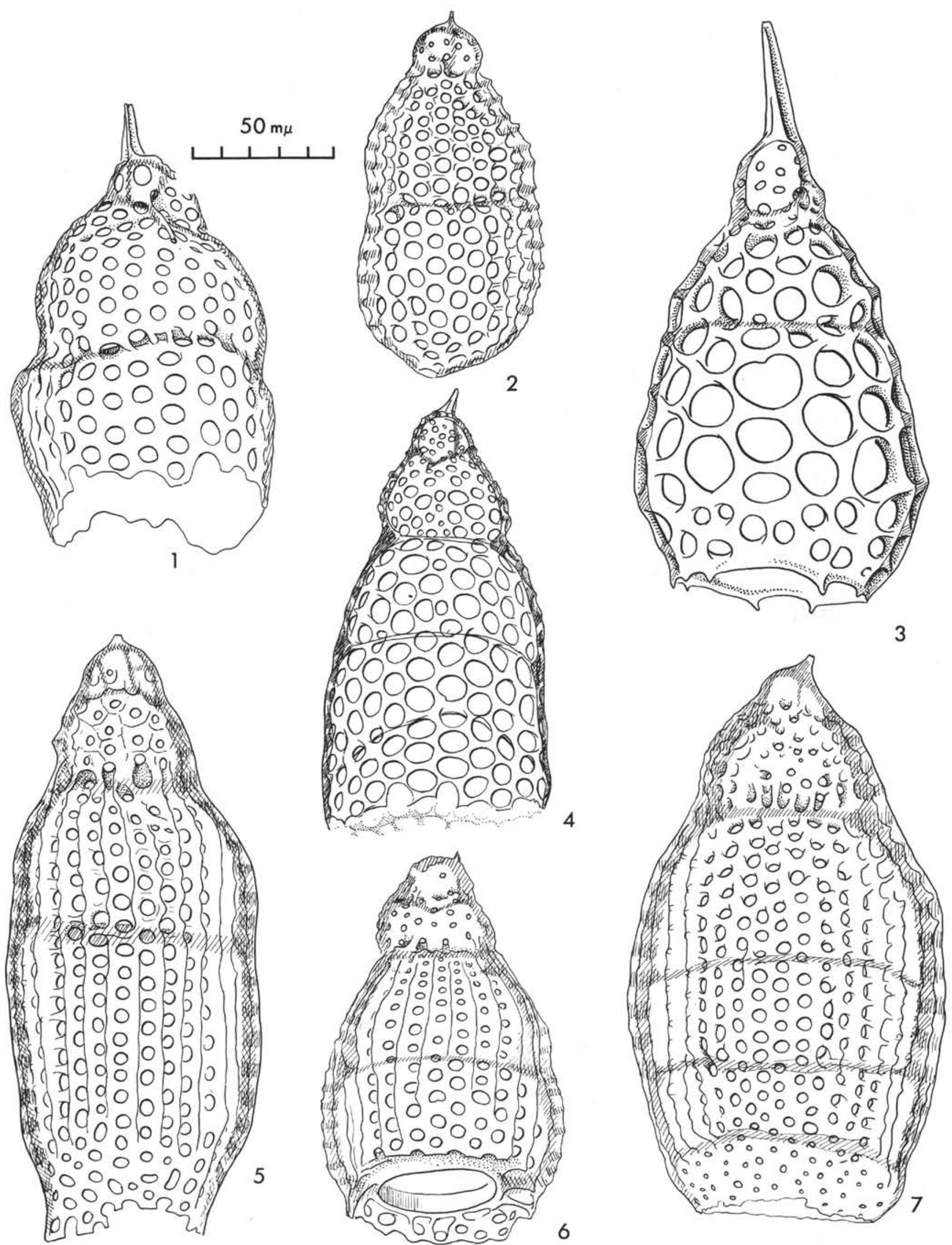




\section{PLATE 23}

All figures $\times 550$

Figure 1 Clathrocyclas titanothericeraos. 29-278-20-3.

Figure 2 Clathrocyclas bicornis (Popofsky) group. $\mathrm{Ob}$ Station 233; surface sediment.

Figure 3 Clathrocyclas bicornis Hays. Ob Station 20; surface sediment.

Figures 4, 5 Clathrocyclas universa amplaspina Clark and Campbell. Californian Eocene; No. 1794.

5. Cephalis of the another specimen.

Figure 6 Clathrocyclas universa nova Clark and Campbell (?) or Theocorys angusta Lipman (?). Siberian Eocene; Ladvinka Core 29, 256-260 m.

Figure 7 Clathrocyclas universa nova (?). Western Siberia, Eocene.

Figure $8 \quad$ Clathrocyclas undella Clark and Campbell (?) or Sethocyrtis elegans Lipman. Russian European Eocene; Core 59, $18 \mathrm{~m}$; Collection of S. Tochilina. 


\section{PLATE 23}
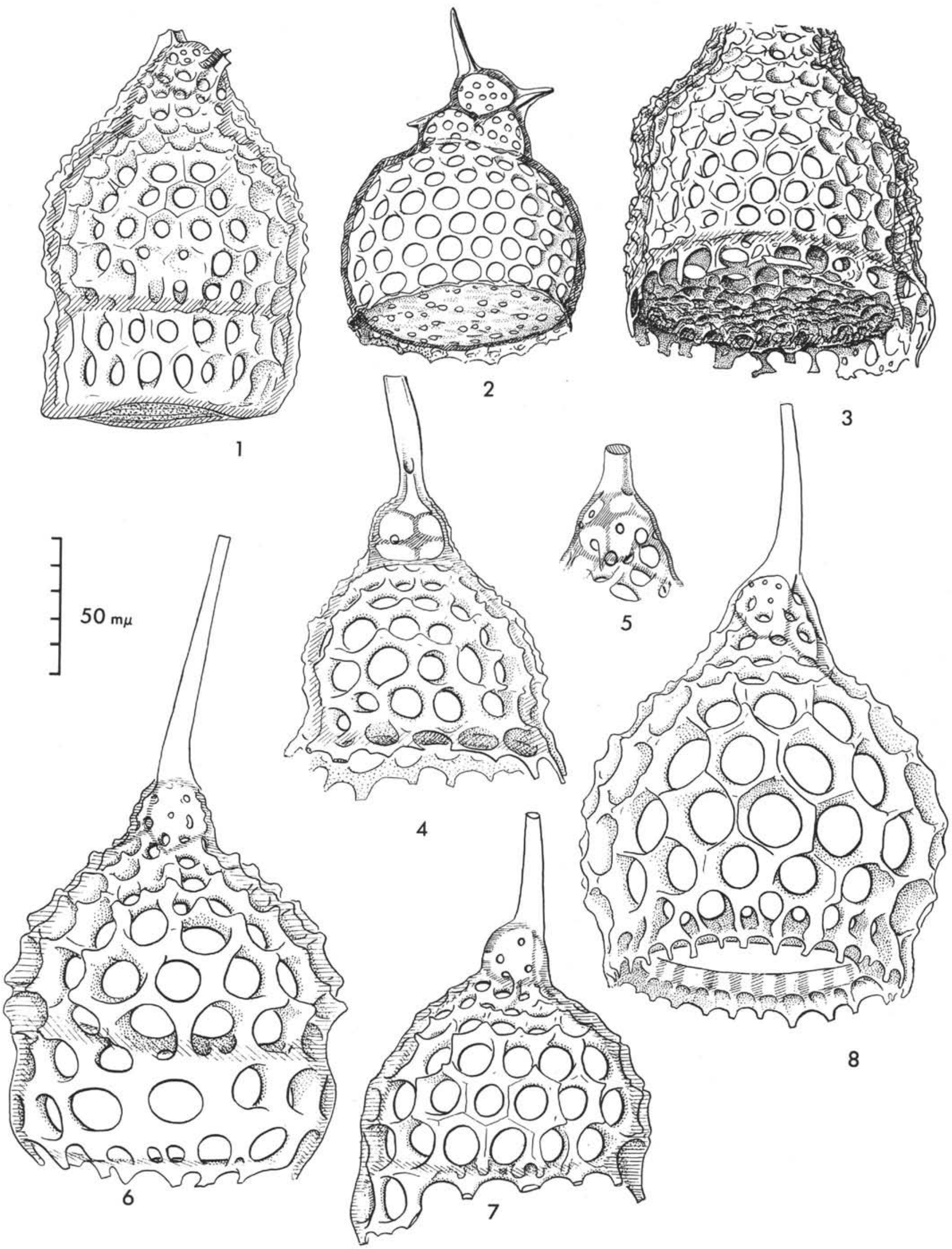


\section{PLATE 24}

\section{All figures $\times 550$}

Figures 1-3 Diplocyclas sp. aff. D. bicorona Haeckel group.

1. North Atlantic, Lomonosov Station 105; surface sediment.

2. North Pacific, Vitjaz Station 3342; surface sediment.

3. Miocene, AMPH 6 P.

Figure 4 Diplocyclas sp. A. 29-280A-2-2.

Figure $5 \quad$ Clathrocyclas bicornis (Popofsky). Ob Station 274; plankton; $500 \mathrm{~cm}$.

Figure 6 Diplocyclas ionis (Haeckel) group. Californian Miocene, Malago Mudstone.

Figure 7 Caldoscenium advena (Clark and Campbell) group. $29-278-32-5,40 \mathrm{~cm}$.

Figure $8 \quad$ Lithomelissa sp. aff. L. haeckeli Bütschli. 29-280A$6, \mathrm{CC}$

Figure $9 \quad$ Antarctissa sp. aff. A. clausa (Popofsky). 29-278$16-2,40 \mathrm{~cm}$. 
PLATE 24
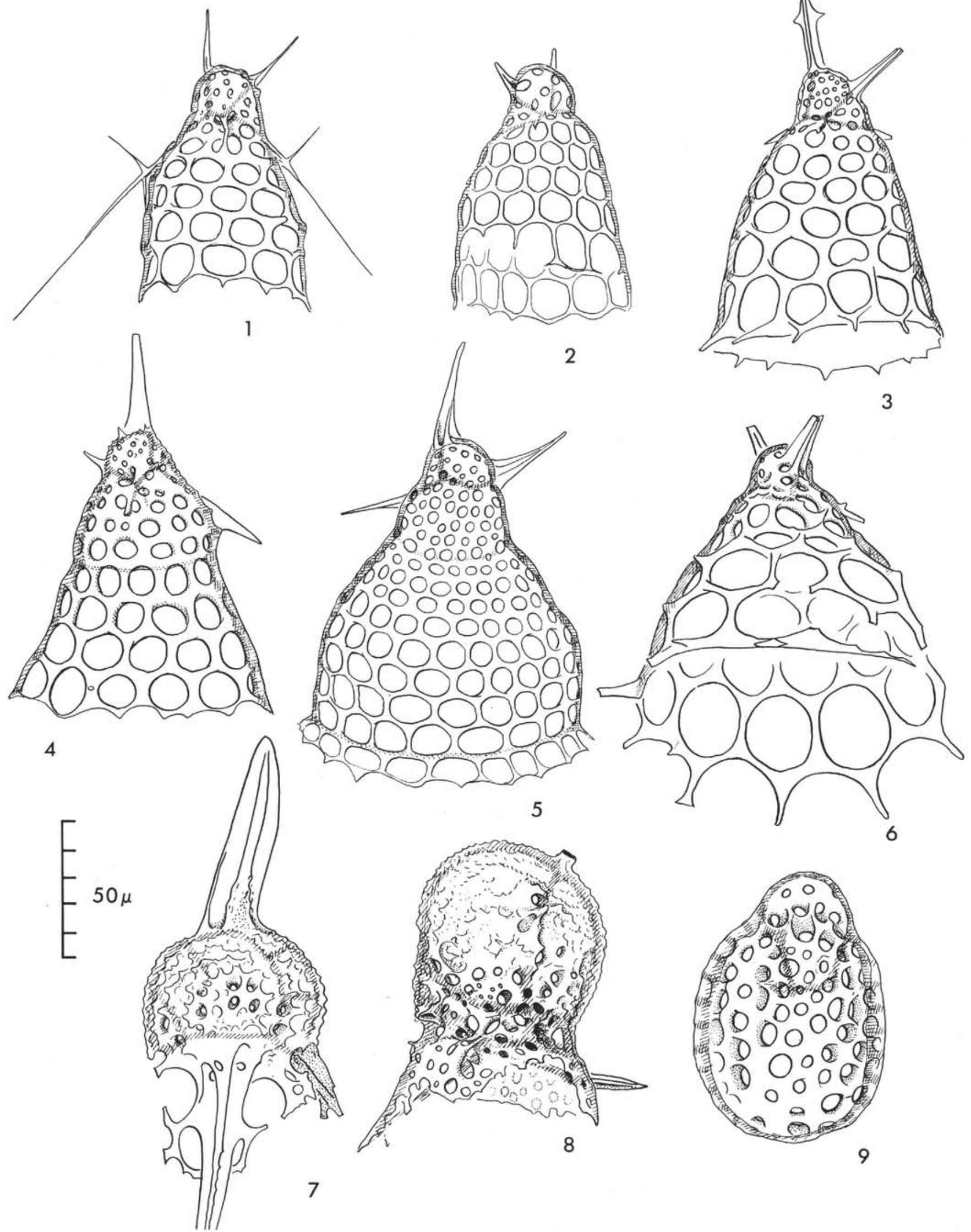


\section{PLATE 25}

Figures 1, 2 Dictyophimus archipilium n. sp. 29-278-22-3.

1. Holotype.

Figures 3, 4 Dictyophimus splendens (Campbell and Clark). Californian Miocene, Delmont.

Figure $5 \quad$ Gondwanaria sp. 29-278-25-1.

Figures 6, 7 Pterocanium sp. (trilobum sensu Hays?).

6. $\mathrm{Ob}$ Station $111 ; 652-654 \mathrm{~cm}$.

7. $O b$ Station 17; surface sediment.

Figure $8 \quad$ Dictyophimus crisae Ehr., Vitjaz Station 4522; surface sediment.

Figures 9, 10 Anthocyrtella? kruegeri (Popofsky) group. Middle Miocene form.

9. 29-278-16-6, typical

10. $29-278-18-4$.

Figure $11 \quad$ Anthocyrtella ? kruegeri (Popofsky) group. Recent tropical form; RIS; 13 Jan 1961; night, surface plankton. 
PLATE 25

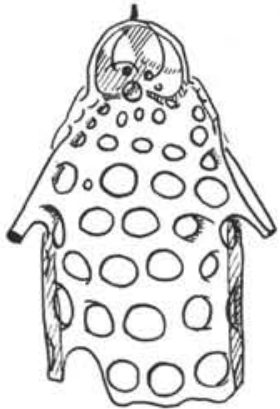

1
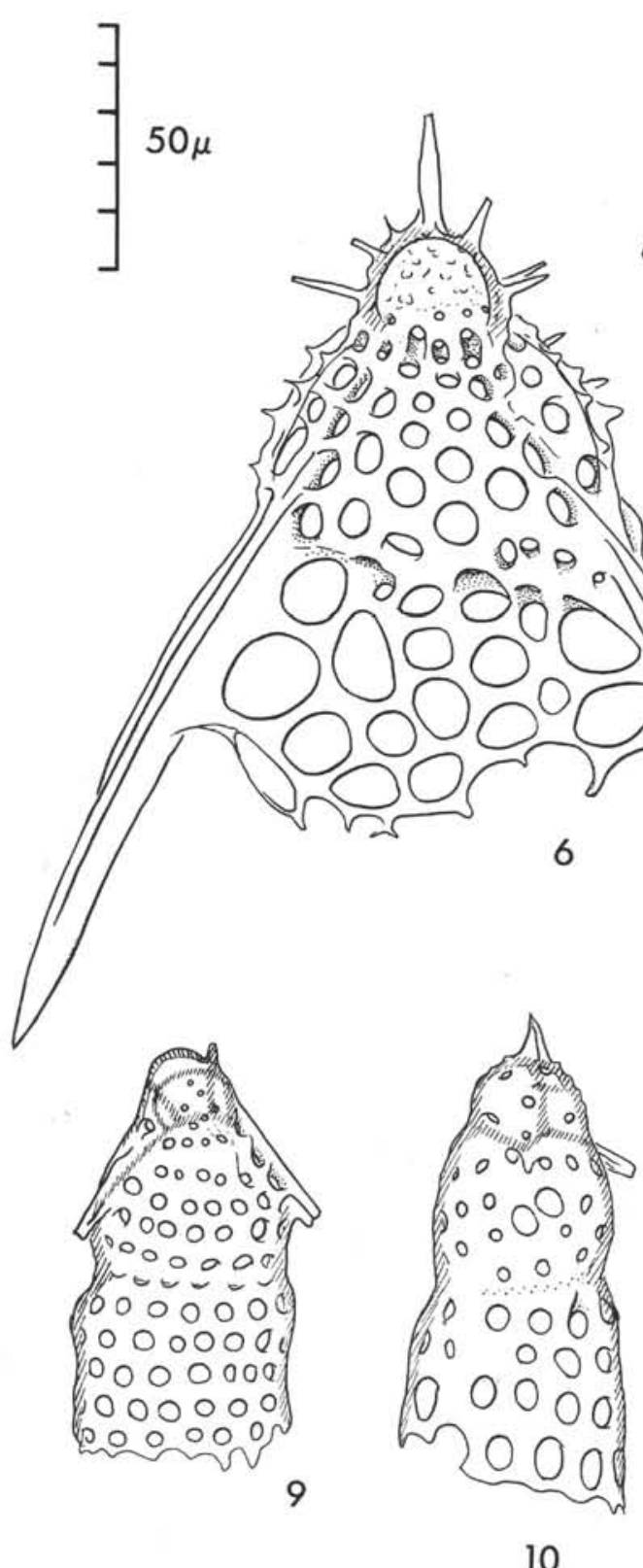

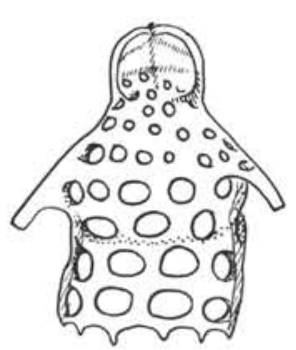

2

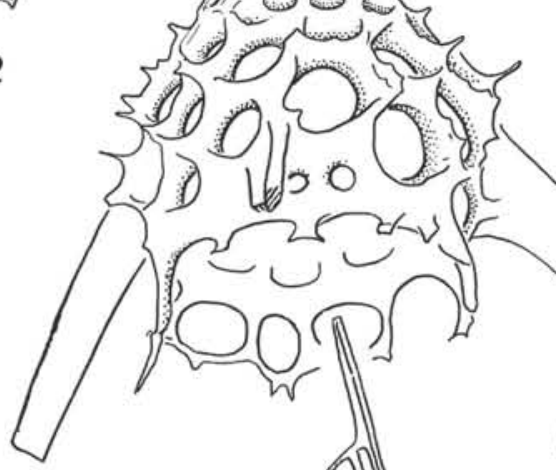

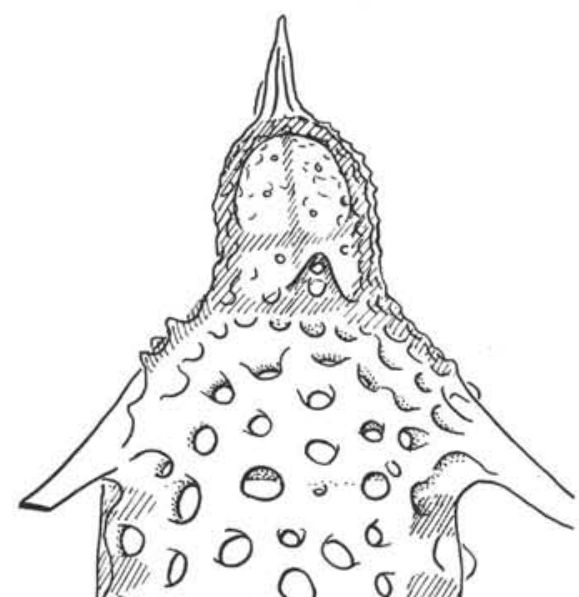
$0_{0} 0$

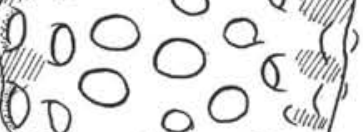


PLATE 26

Figures 1, 2 Artostrobus pusillum (Ehrenberg) group, 1. 14-144-2-2 bottom; Paleocene.

2. $29-278-33-1$.

Figure 3 Theocampe sp. aff. Th. minuta (Clark and Campbell). 29-280A-1-4, $70 \mathrm{~cm}$.

Figure 4 Theocampinae gen. sp. 14-144-2-2 bottom; Paleocene.

Figure 5, 6 Theocampe minuta (Clark and Campbell) group. 29-278-34-1, $37 \mathrm{~cm}$.

Figures 7, $8 \quad$ Stichopodium inflatum (Kling).

7. 29-278-9-2.

8. 29-278-9-3.

Figure 9 Lithomitra sp. B. 29-280A-6, CC.

Figure $10 \quad$ Botryopyle dionisii n. sp. 29-278-28-5, $40 \mathrm{~cm}$; Holotype.

Figure $11 \quad$ Botryocylinder sp. 14-144-2-2, bottom; Paleocene.

Figure 12 Botryocylinder?? sp. 14-144-2-2, bottom; Paleocene.

Figure 13 Botryometra poljanskii n. sp. 29-278-10-6; Holotype. 
PLATE 26

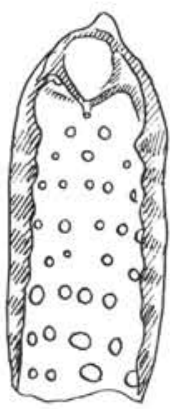

1

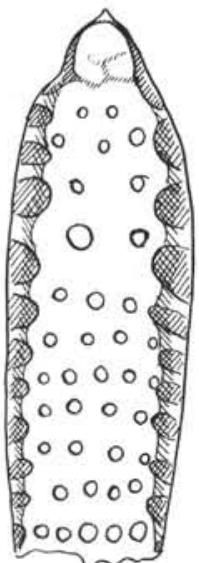

2
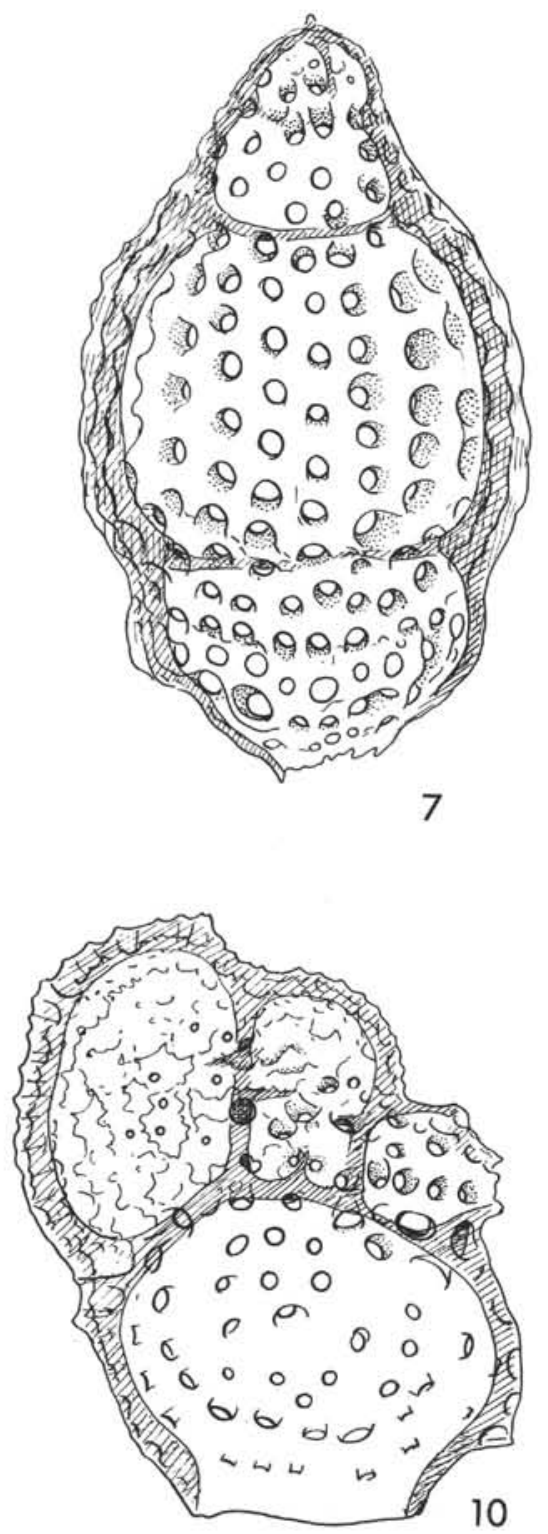
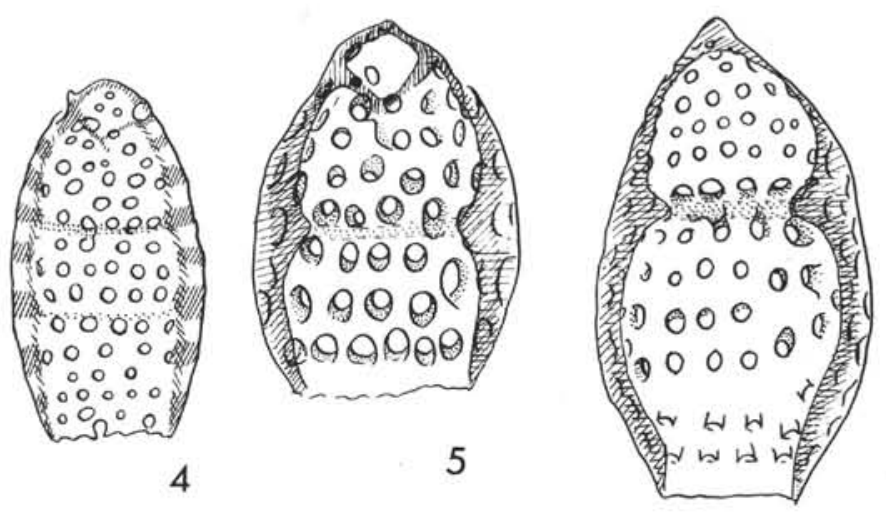

3
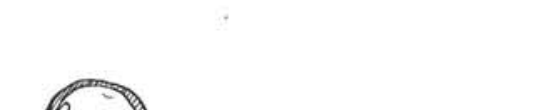

6

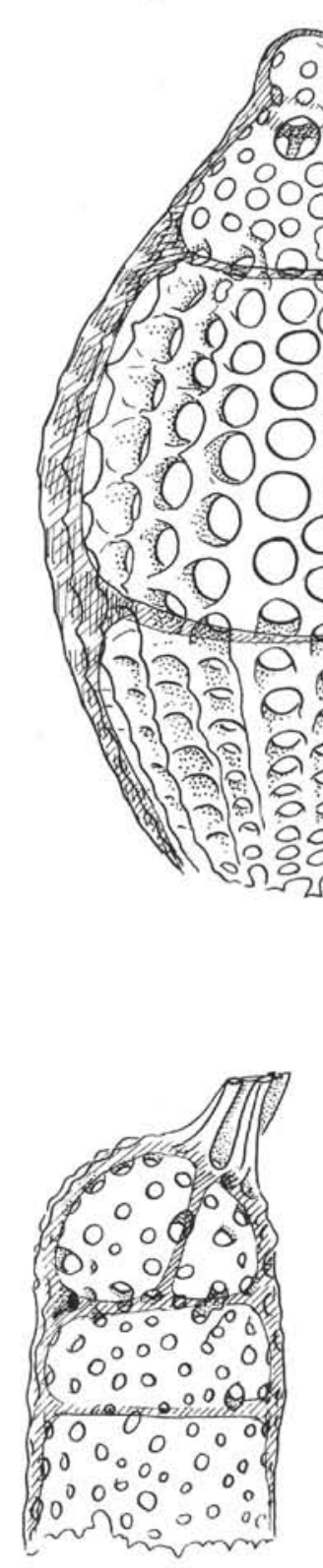

11
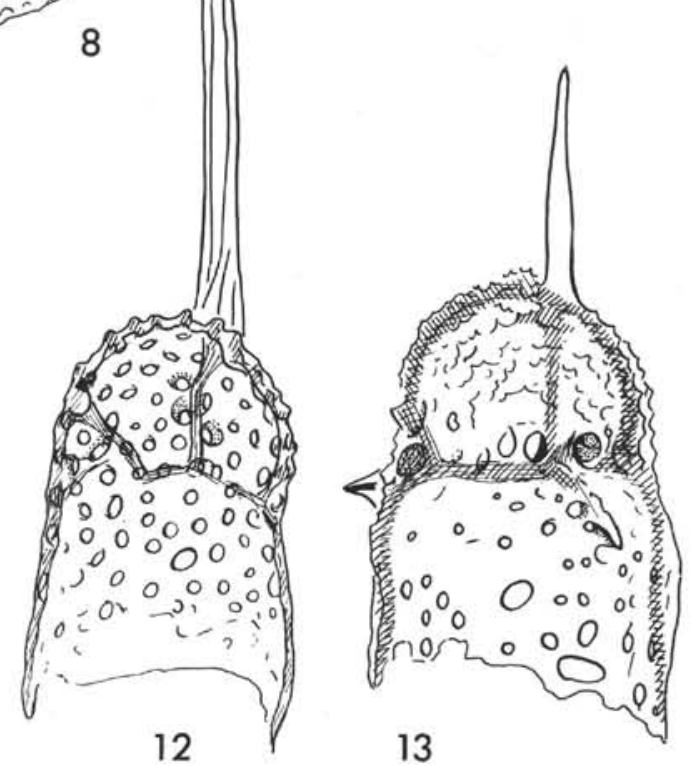
PLATE 27

Figures 1, 2 Triceraspyris antarctica (Haecker) typ. surface sediment, $O b$ Stations

1. Station 238

2. Station 220

Figure 3 Tristylospyris sp. cf. antarctica, surface sediment, Ob Station 249.

Figures 4-6 Desmospyris ? haysi n. sp. Atypical Quaternary (?)

4. $O b$ Station 52; surface sediment.

5, 6. $O b$ Station 271 ; surface sediment.

Figure $7 \quad$ Tristylospyris sp. cf. antarctica. Ob Station 194; surface sediment.

Figure 8 Desmospyris spongiosa Hays. 29-278-22-2.

Figure 9 Cystophormis sp. Ob Station 125; 21-24 cm. 

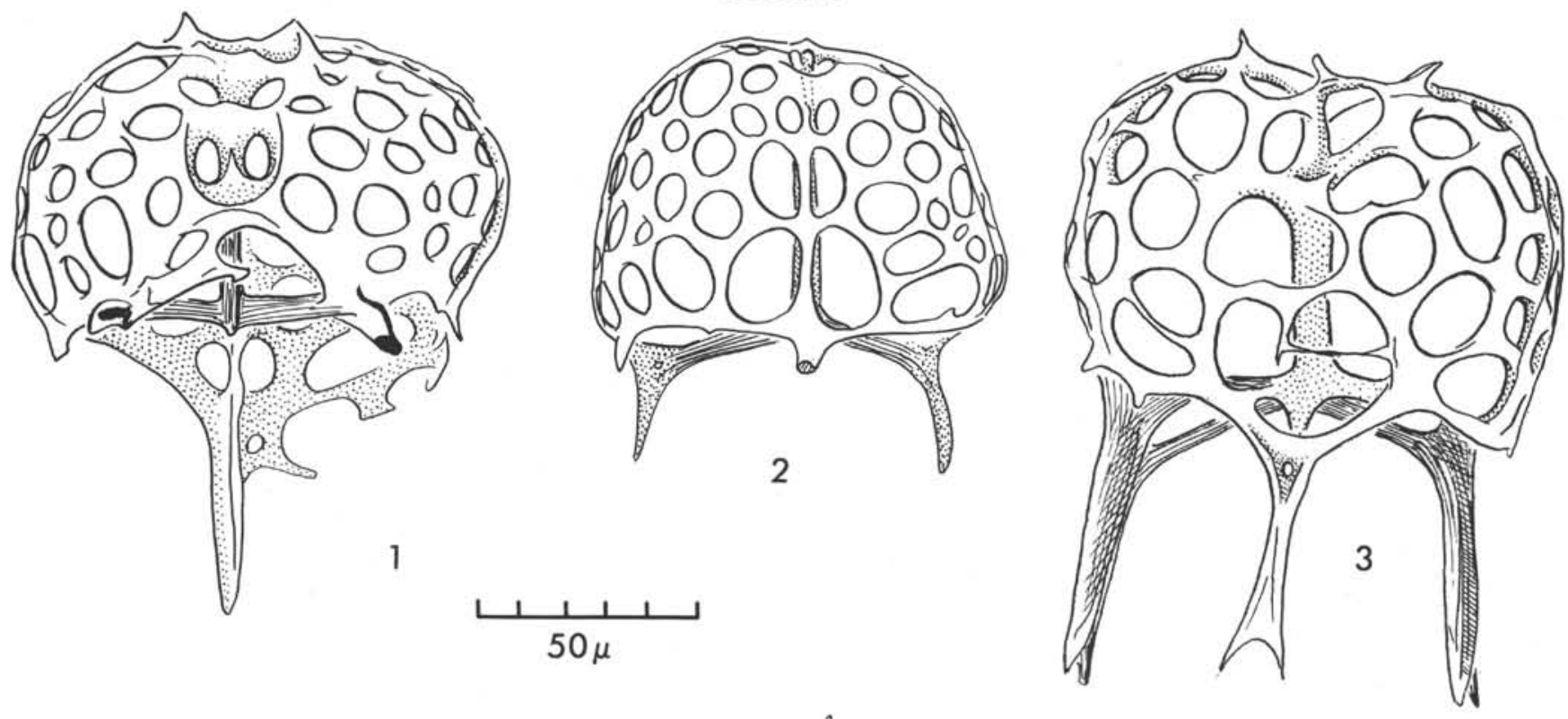
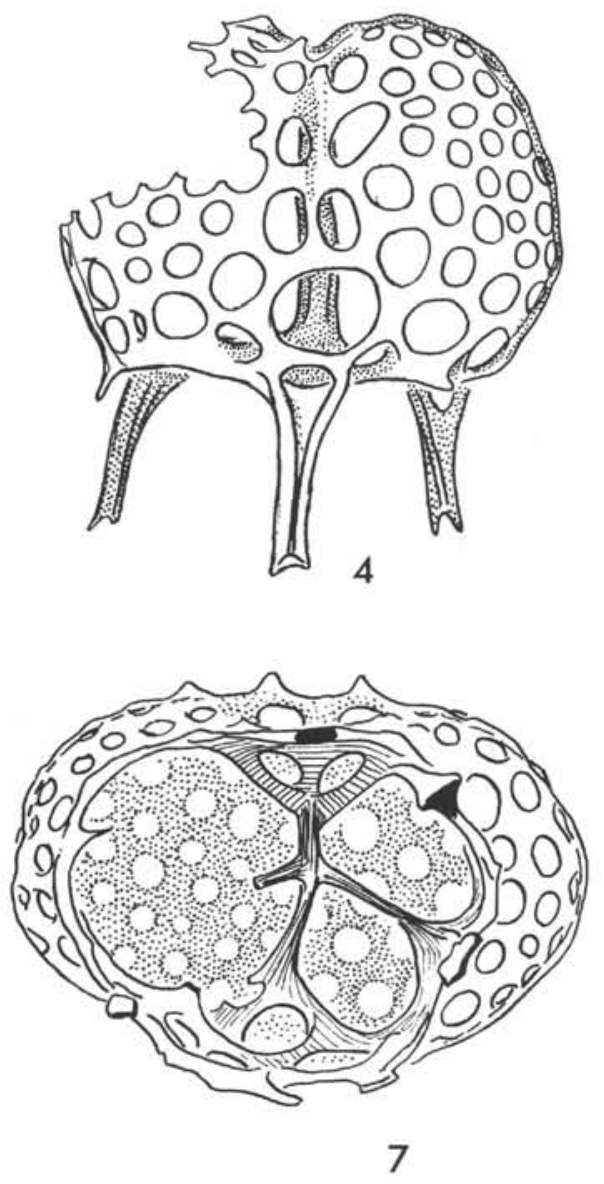

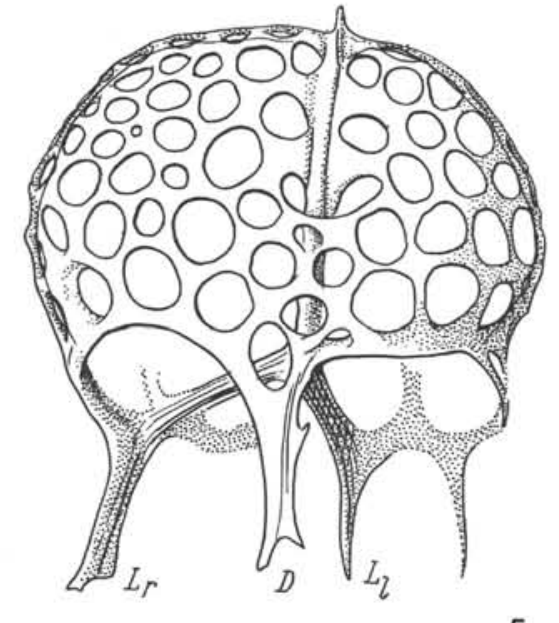

5

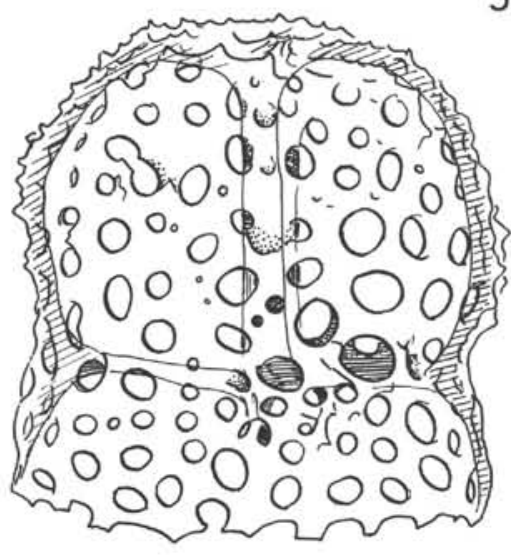

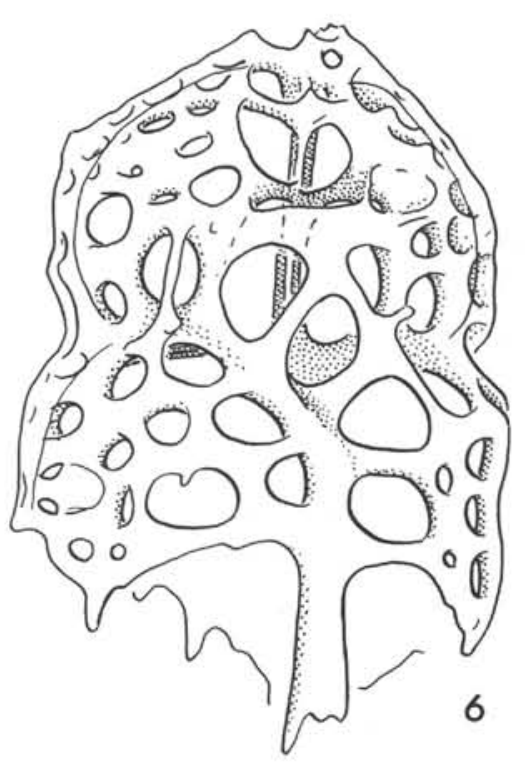

8

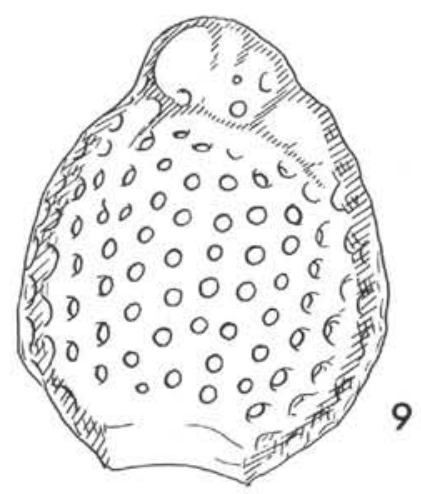




\section{PLATE 28}

Figure $1 \quad$ Amphisphaera sp. 29-278-24-3; $\times 260$; spines broken.

Figures 2-6 Amphisphaera sp. aff. Stylatractus neptunus Hck. 2. $\mathrm{Ob}$ Station 285; surface sediment; $\times 400$.

3. Same specimen; $\times 800$; the complicated end of the spine can be seen.

4. Same specimen $\times 5200$.

5, 6. Two other specimens from the same sample (Ob Station 285); $\times 180$; with simple spine ends.

\section{PLATE 29}

Figures 1-3 Spongosphaera pachystula Ehrenberg; Vitjaz Station 5124 , surface sediment.

1. $\times 400$; spongy shell broken, microsphere can be seen.

2. $\times 1250$; base of spine with deep furrows.

3. $\times 250$; whole skeleton of that specimen.

Figure 4 Archaeospongoprunum sp., DSDP 208-28-4, $70 \mathrm{~cm}$; Eocene; $\times 470$.

Figure $5 \quad$ Stylosphaera sp. C group. 29-278-27-3; $\times 540$; spines are three-edged from base to end.

Figure 6 Lithocarpium polyacantha (Campbell and Clark). 29-280A-6, CC; $\times 240$; the pylom is seen.

(See p. 654)

\section{PLATE 30}

Plegmosphaera monikae n. sp., 29-280A-3-4

Figure $1 \times 230$; typical.

Figure 2 Same specimen; $\times 580$.

Figure $3 \times 220$; pylom on the right can be seen; atypical form.

Figure $4 \times 230$; pylom can be seen; atypical form.

Figure $5 \times 240$; typical form.

Figure $6 \quad$ Same specimen; $\times 1200$.

Figure $7 \quad$ Broken specimen; $\times 620$. 
PLATE 28

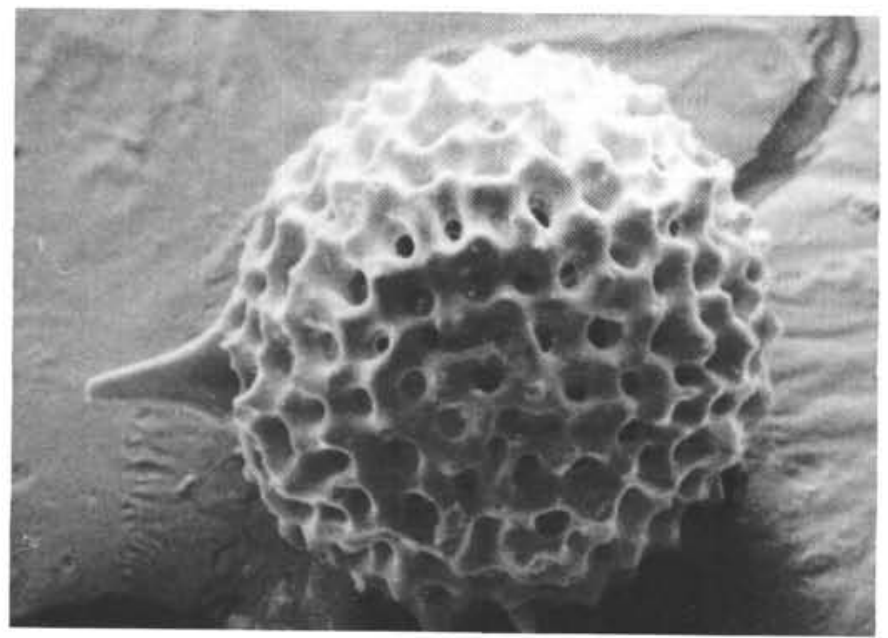

$$
1
$$

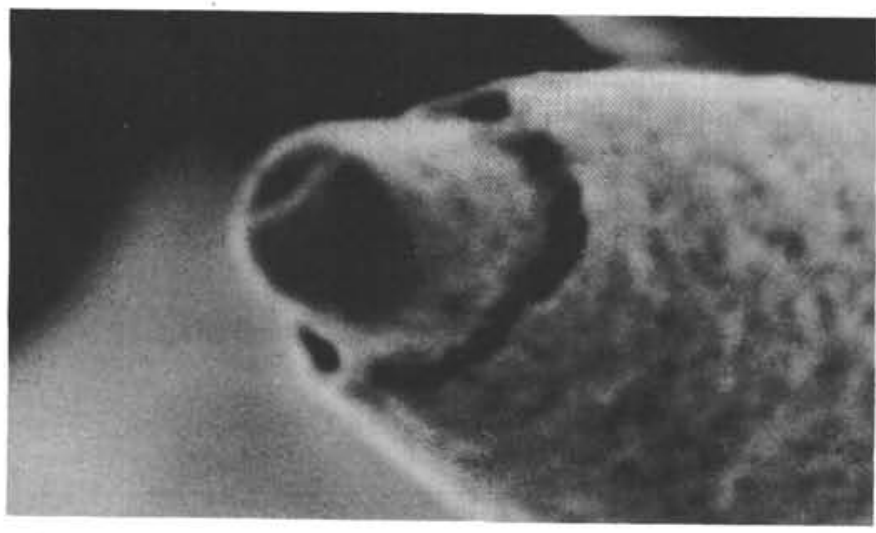

4

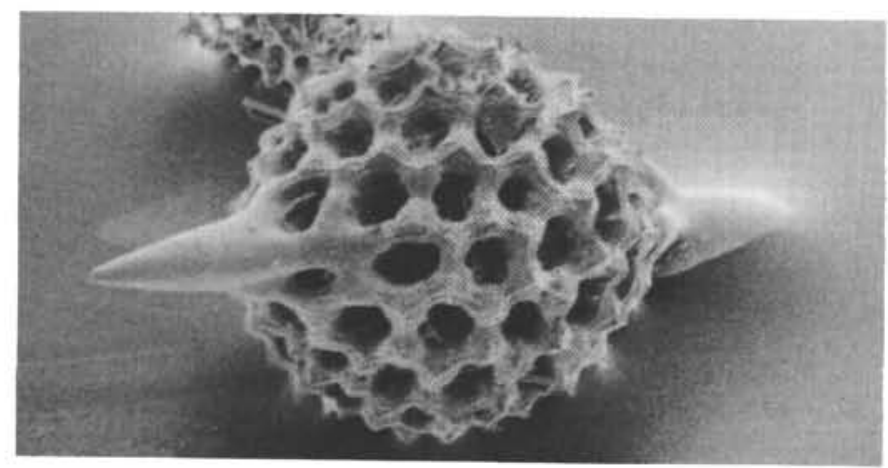

5
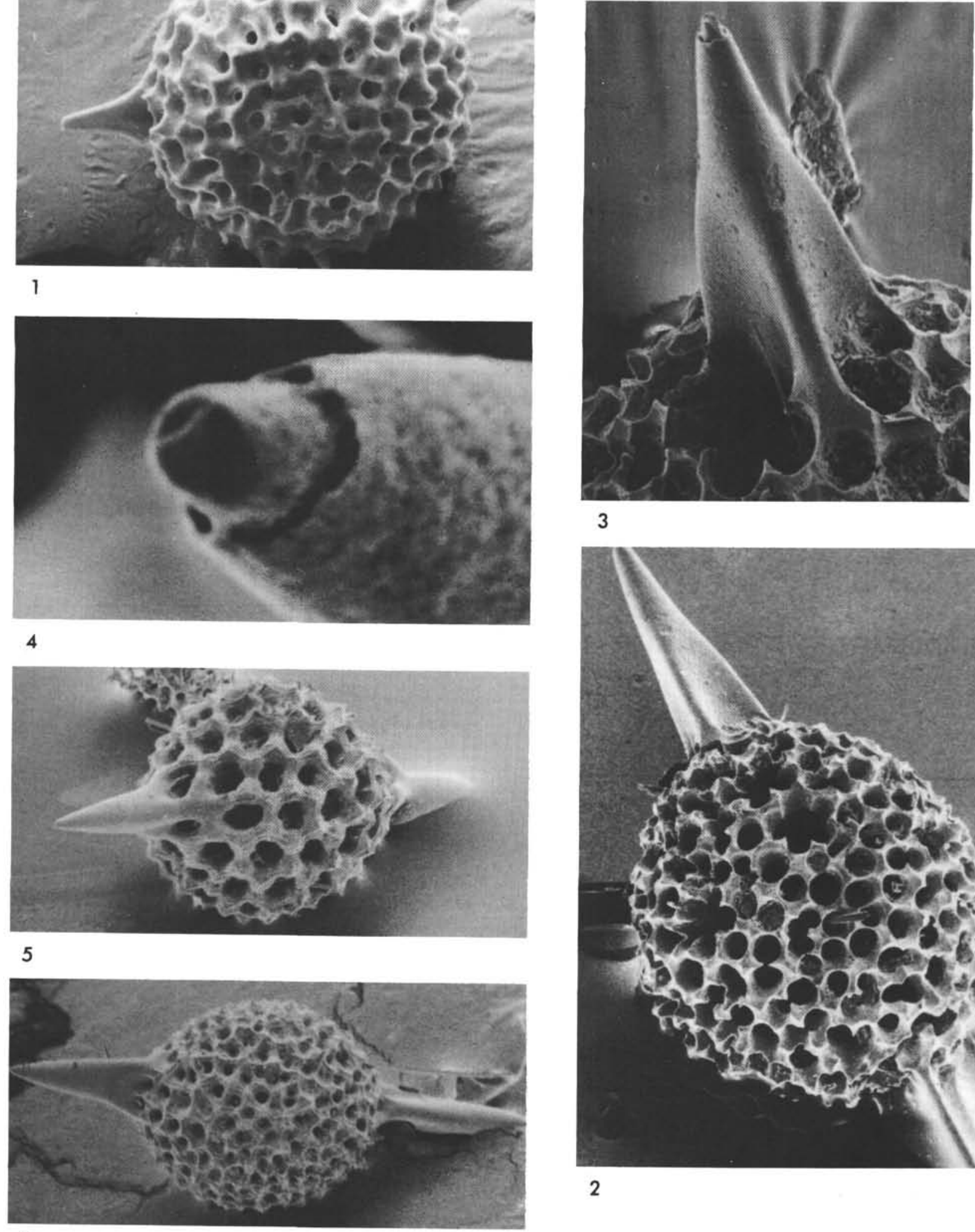

3

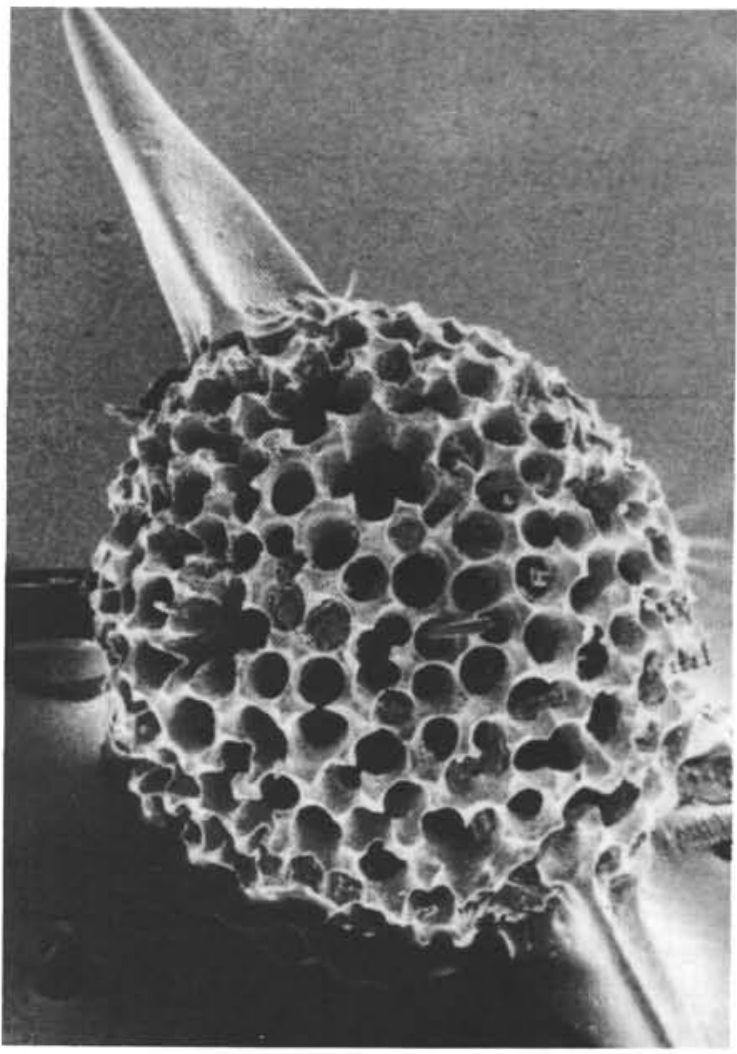

2 
PLATE 29
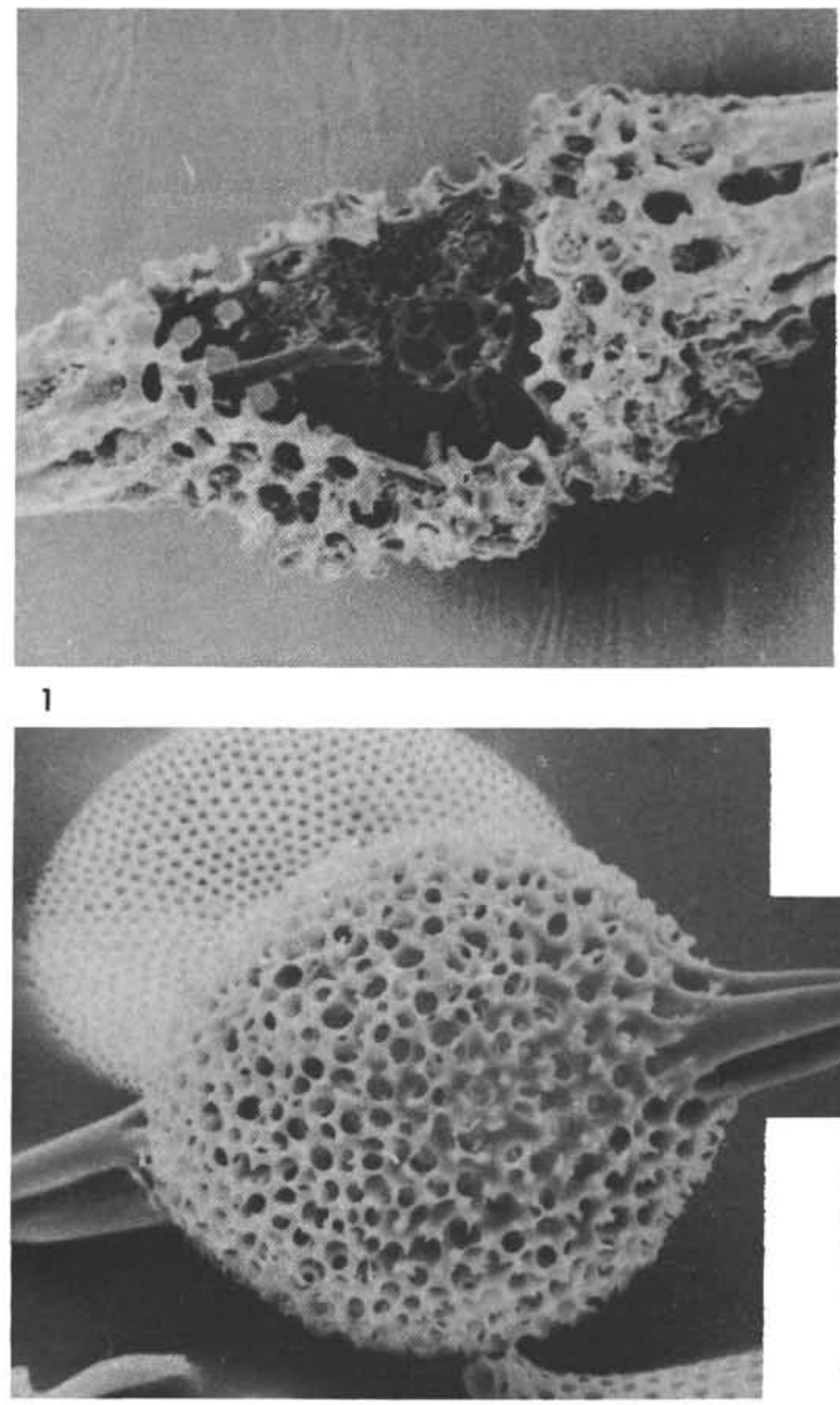

4
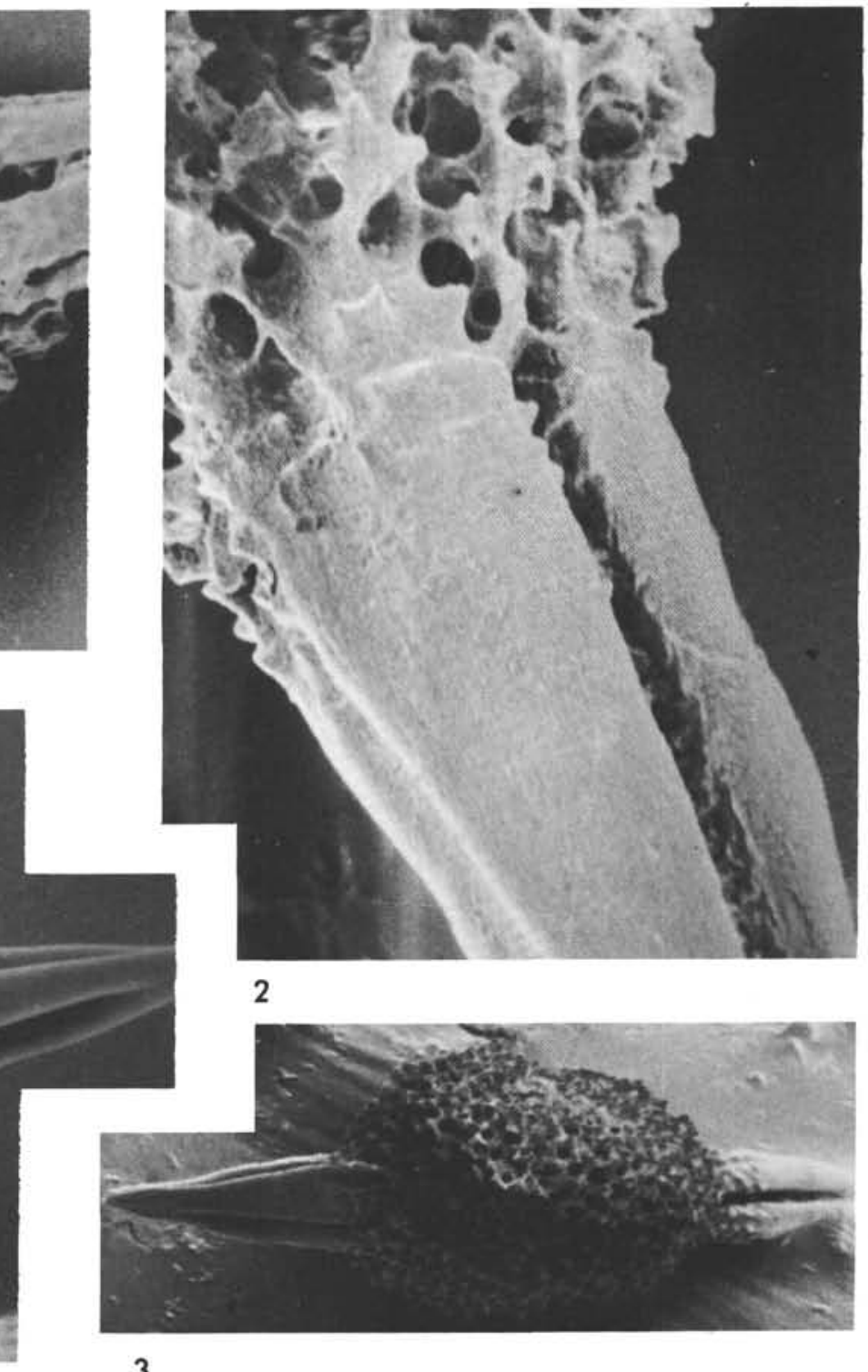

2
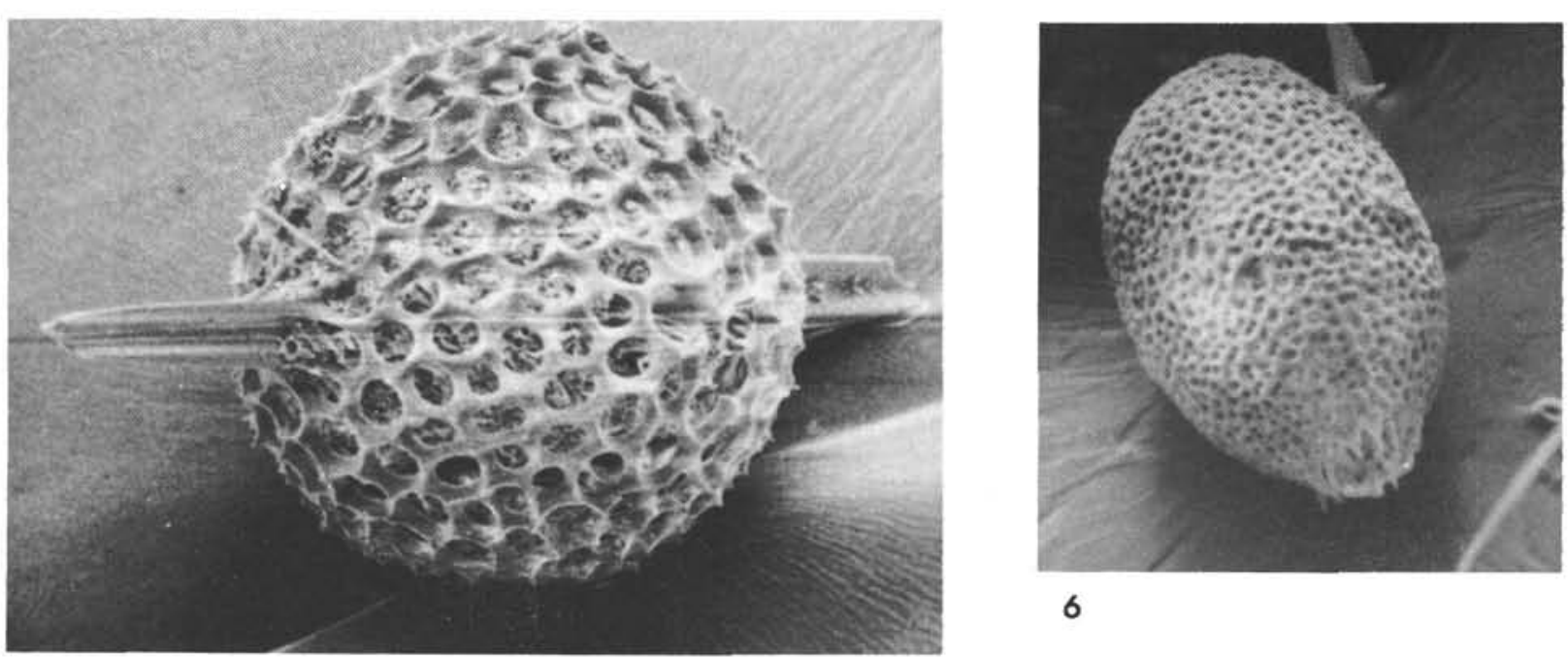
PLATE 30

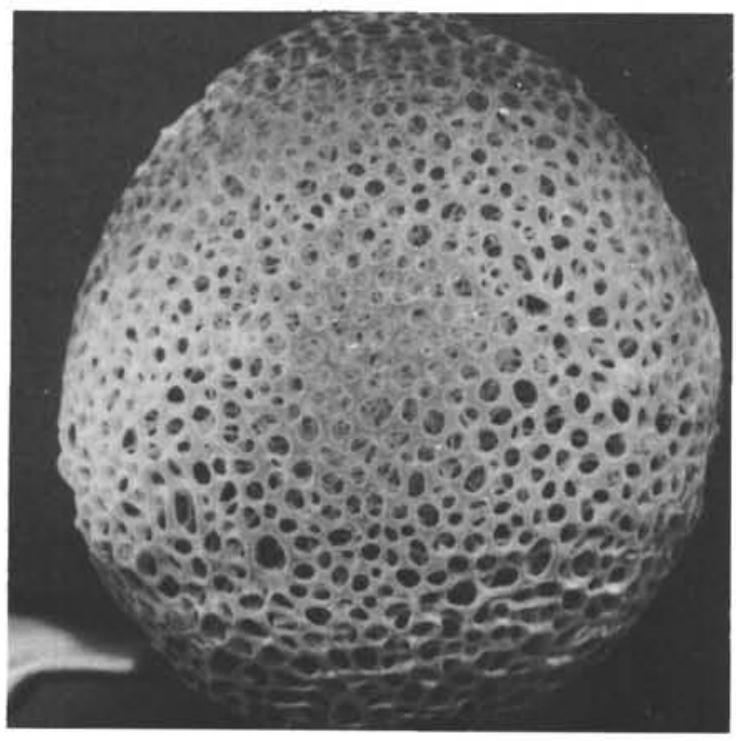

1

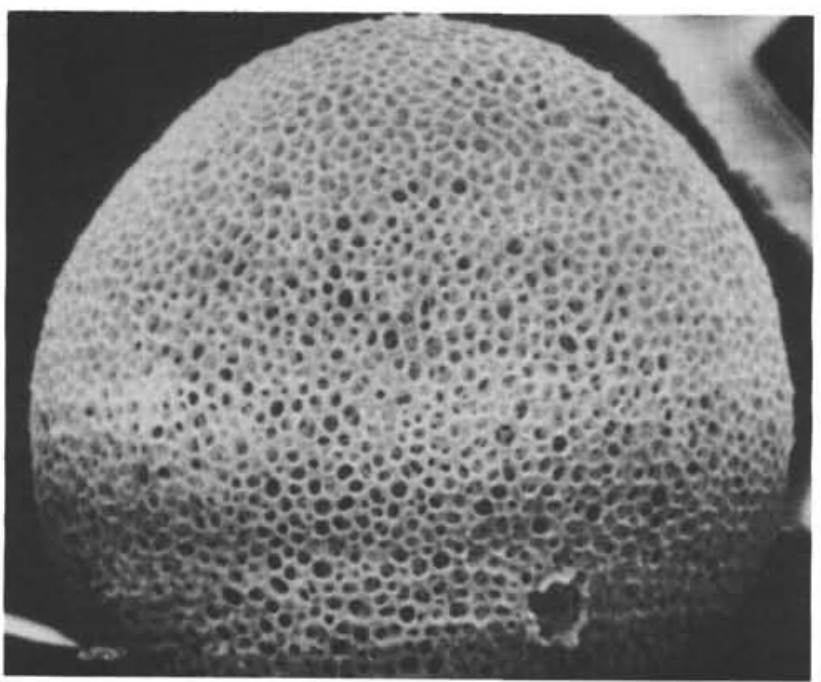

4

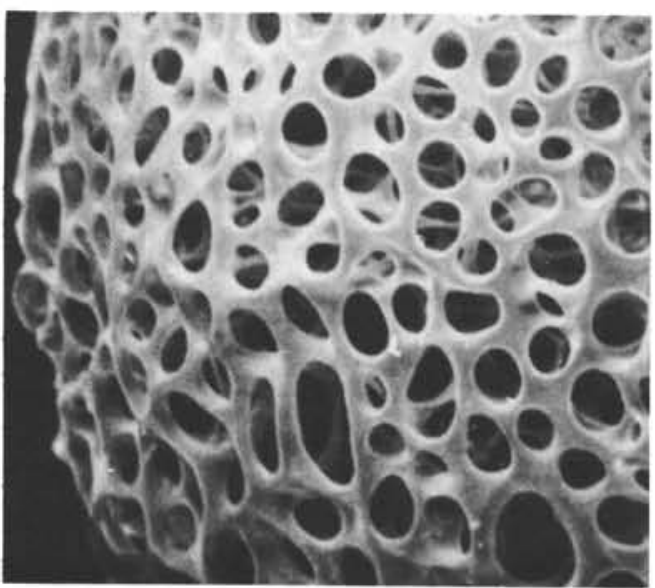

2

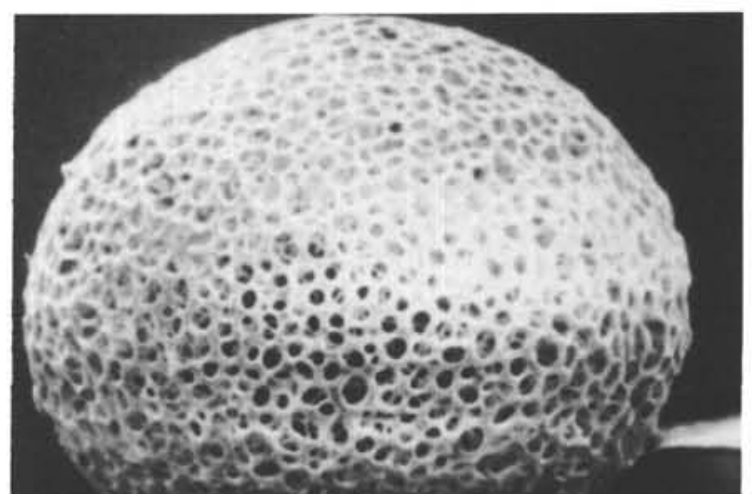

5

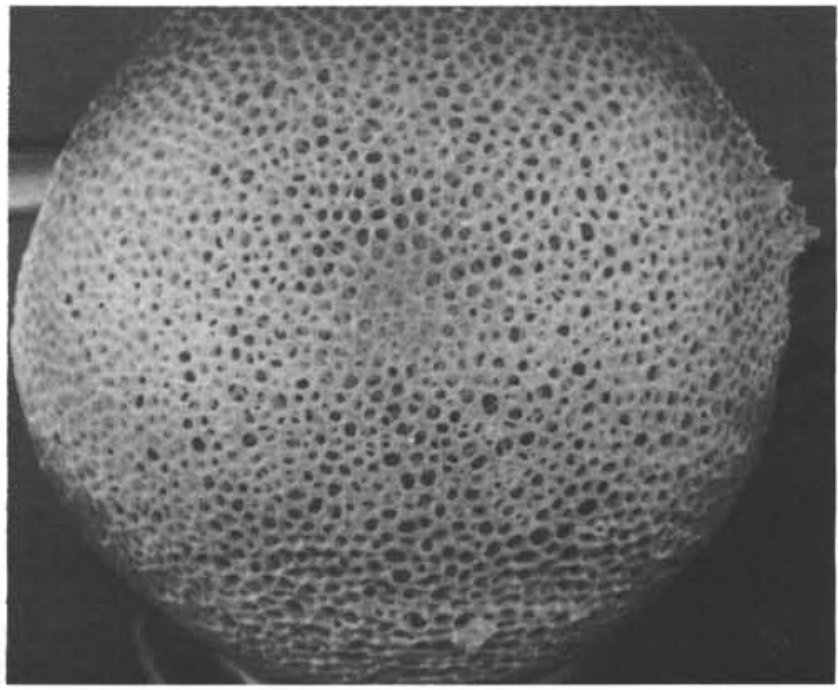

3

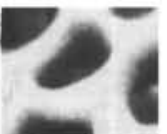

v

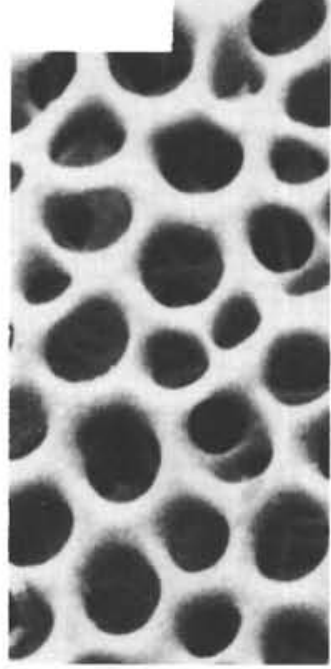

6

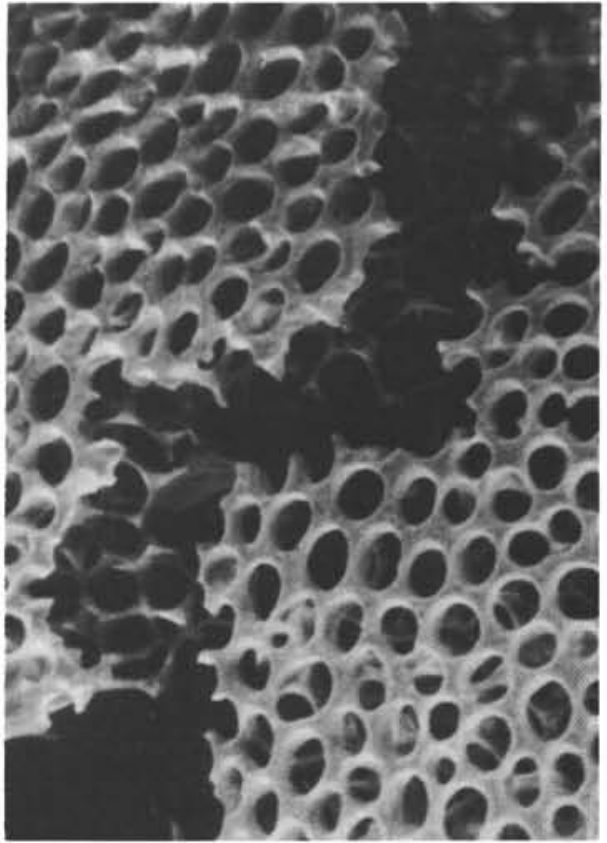

7 


\section{PLATE 31}

Figures 1-4 Lithocarpium sp. aff. L. titan (Campbell and Clark). 29-280-6, CC; pylom can be seen; part of shell is broken;

1. $\times 170$.

2. $\times 425$.

3. $\times 170$.

4. $\times 850$.

Figure $5 \quad$ Cenosphaera ? oceanica Clark and Campbell. 29280-6, CC; $\times 250$.

PLATE 32

Ommatodiscus haeckeli Stöhr

Figures 1-5 29-278-23-3.

1. $\times 220$.

2. $\times 1150$.

3. Same specimen; $\times 950$.

4. Same; $\times 2300$.

5. Same; $\times 2200$.

Figures 6,7 Specimen from from 29-278-27-3.

6. $\times 340$.

7. Same; $\times 725$.

Hollow basement of the radial spines can be seen on Figures 2, 4, 5, and 7.

(See p. 658) 


\section{PLATE 31}
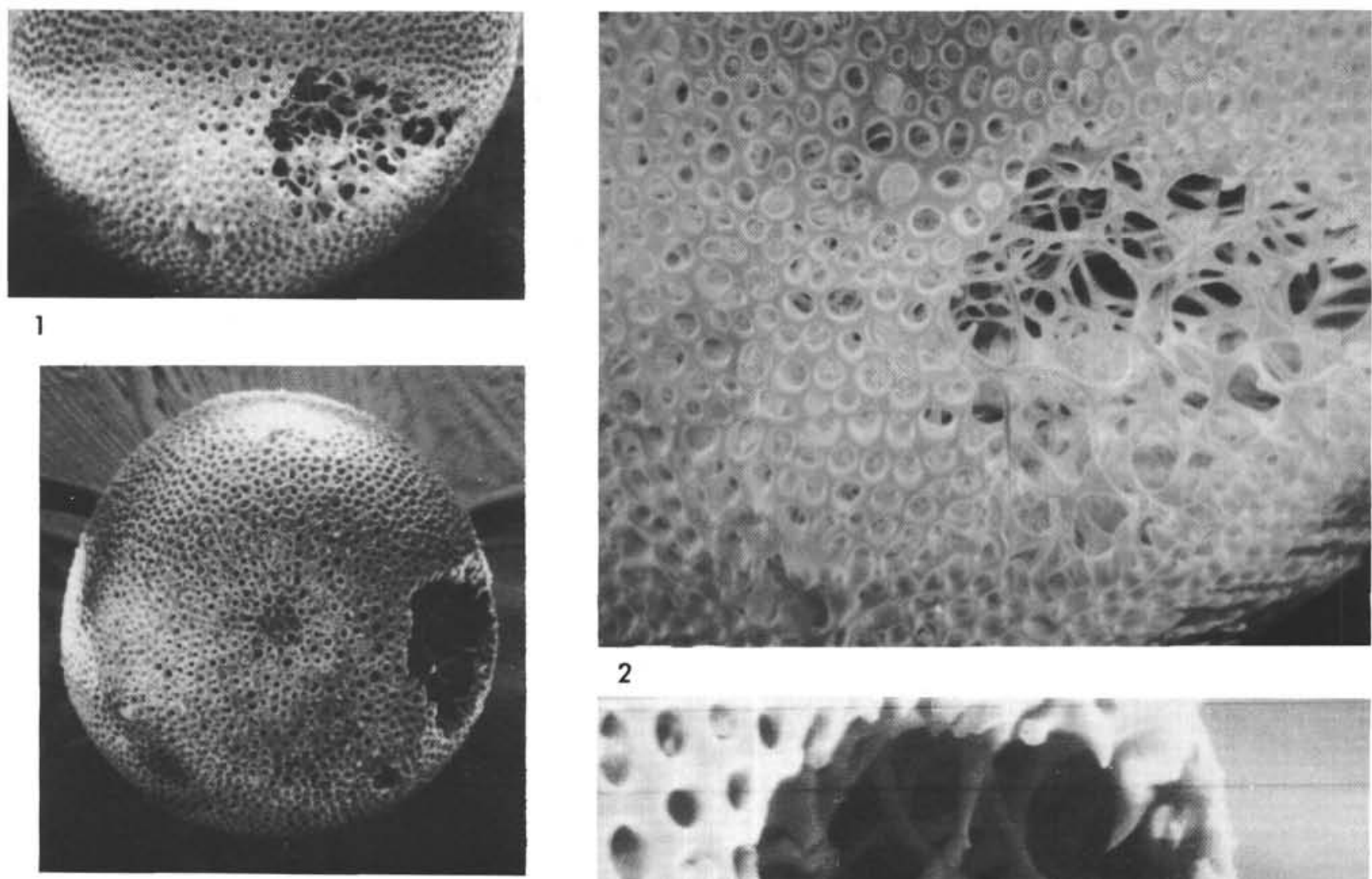

3

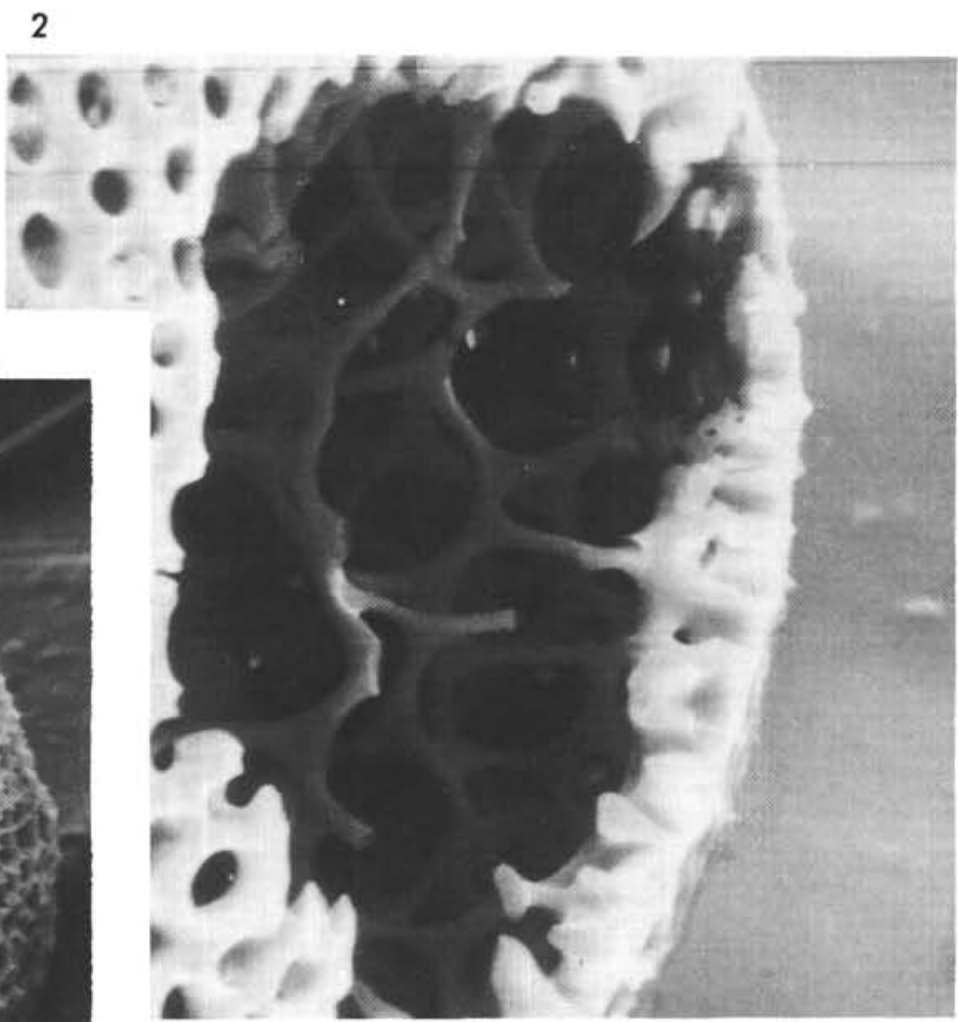

4

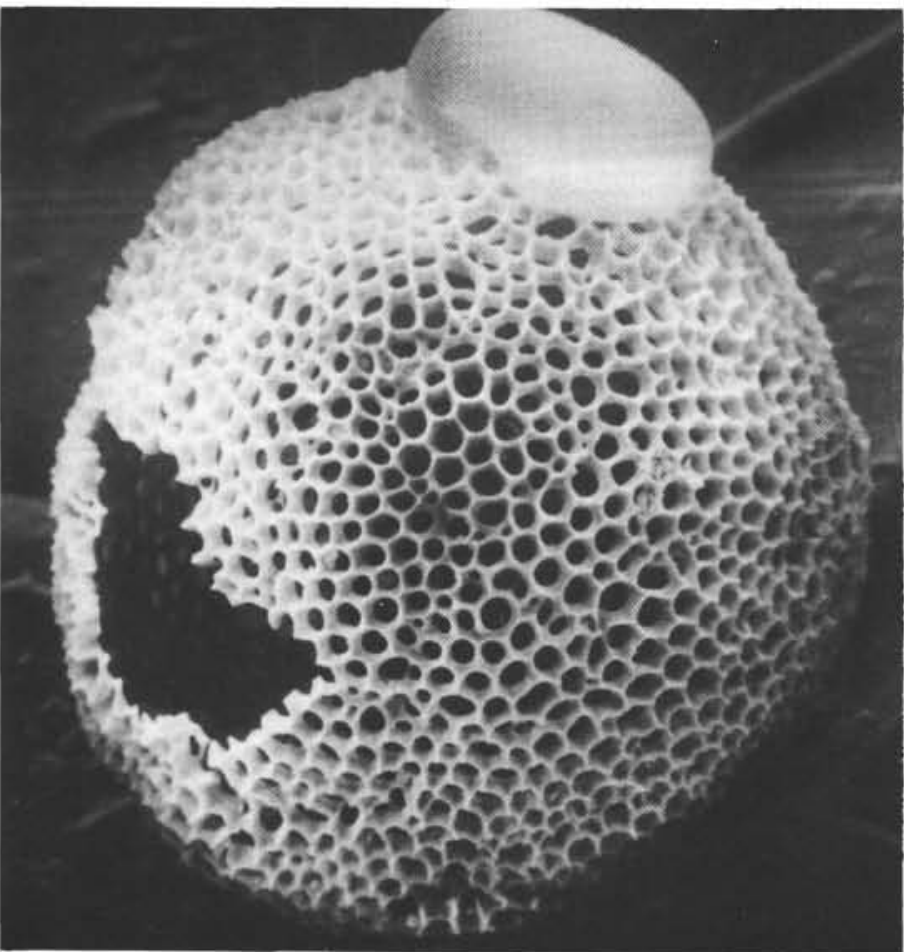


PLATE 32
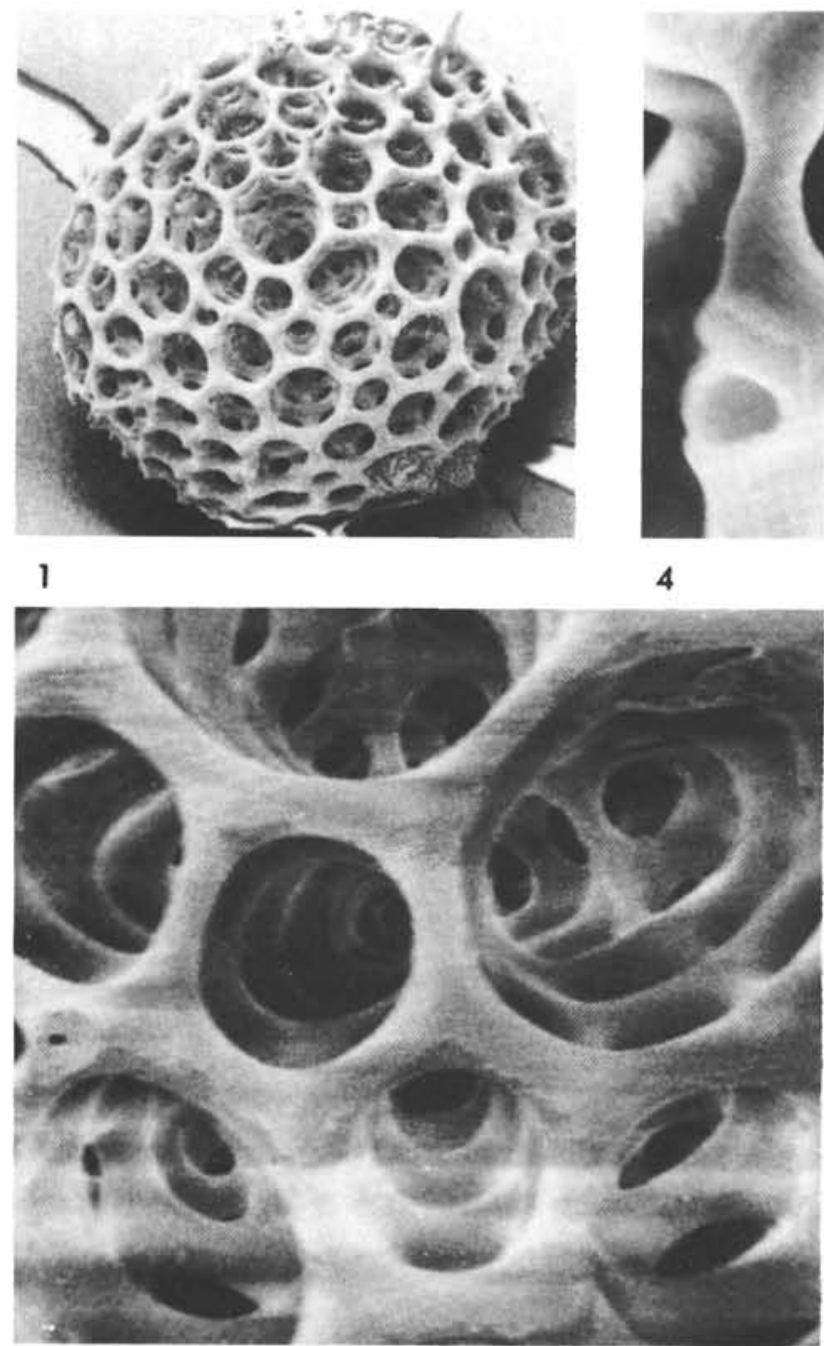

2

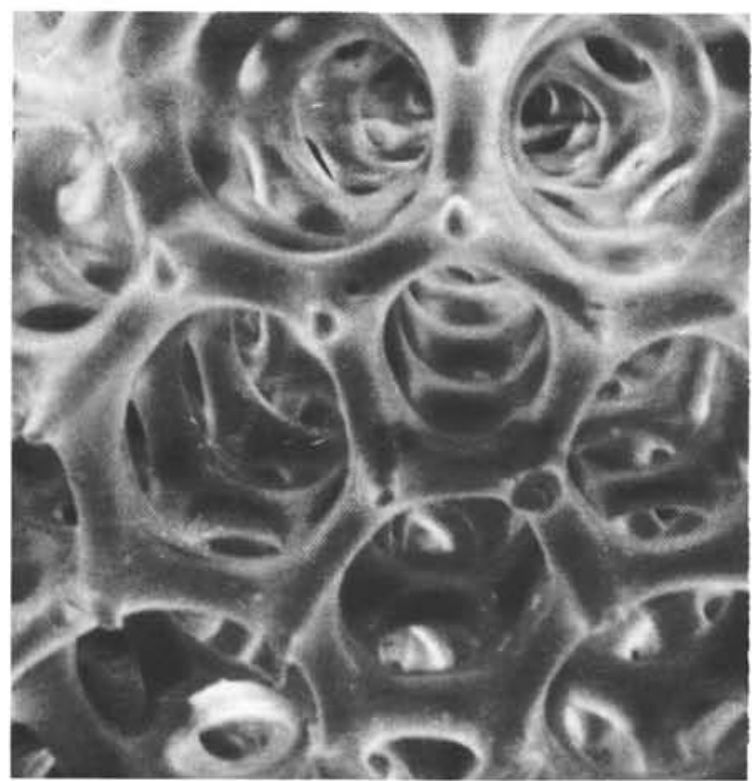

3
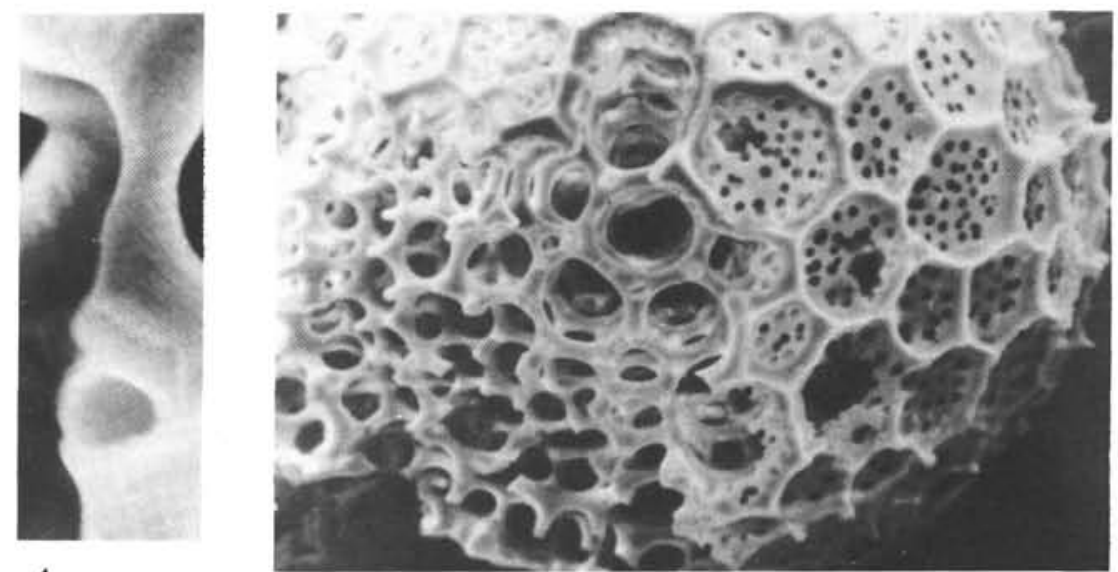

6

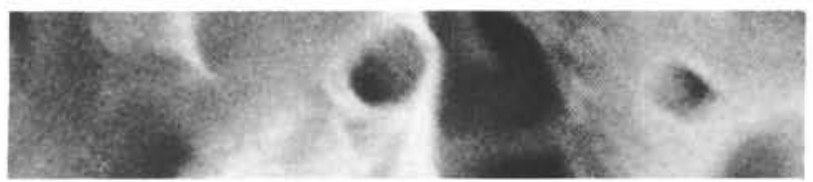

5

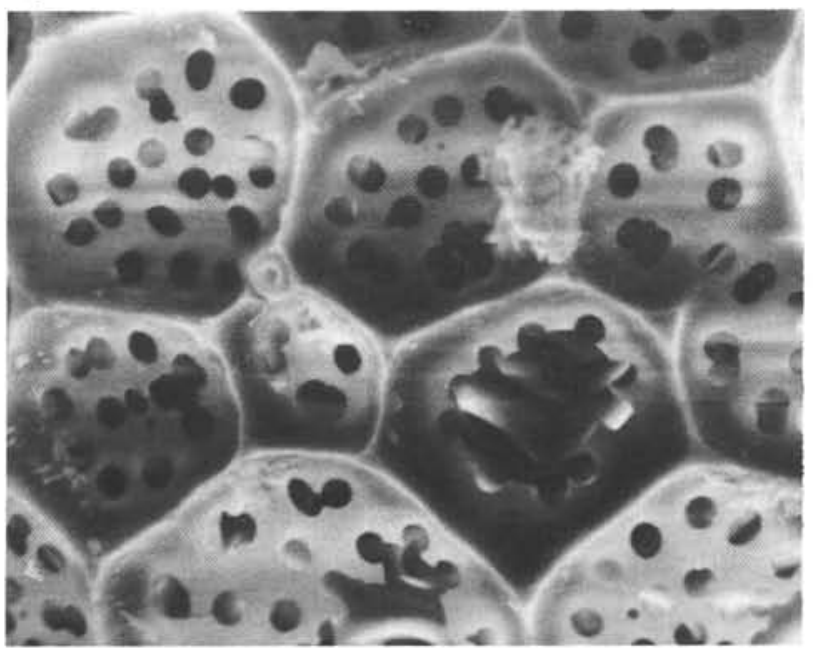

7 


\section{PLATE 33}

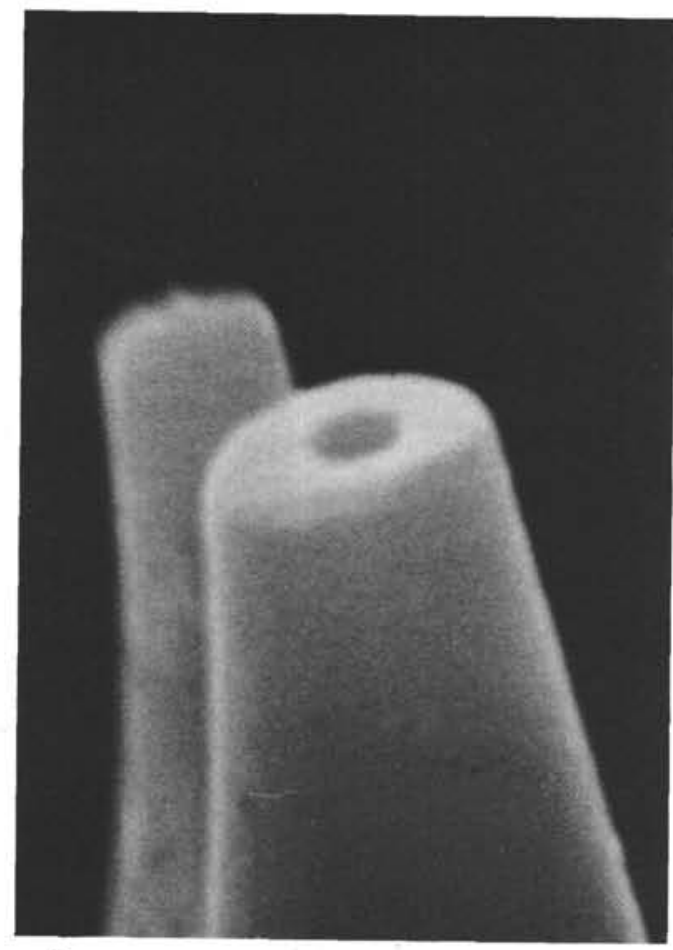

2

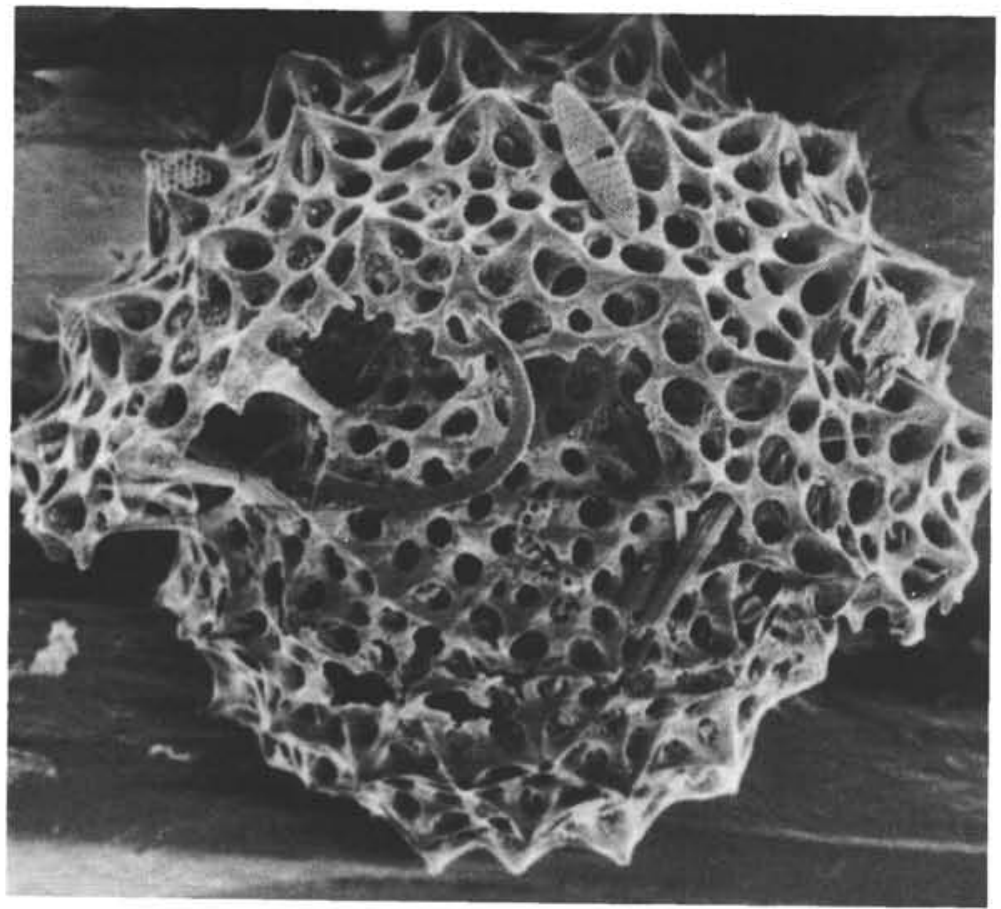

3

1
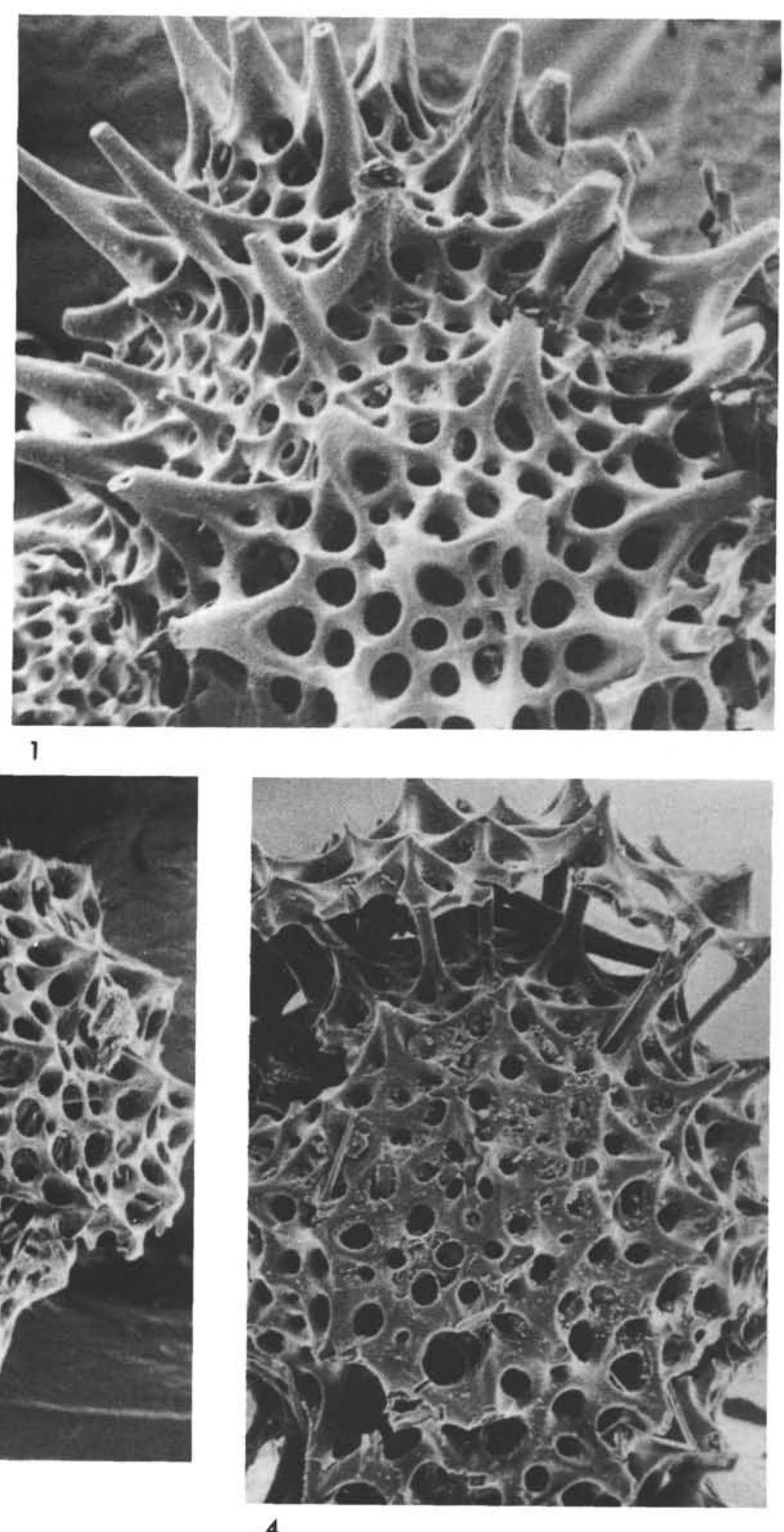

4

Figures 1, 2 Lithelius (?) sp. Vitlaz Station 4522; surface sediment.

1. $\times 670$.

2. $\times 6200$.

Figures 3, $4 \quad$ Lithelius ? nautiloides Popofsky. Ob Station 285.

3. $\times 480$.

4. $\times 520$. 


\section{PLATE 34}

Figures 1, 2 Schizodiscus favus maxima (Popofsky). Ob Station 285; surface sediment.

1. $\times 200$.

2. $\times 1000$.

Figure 3 Pseudoaulophacus sp. or Spongodicid gen. sp. 21208-28, CC; Eocene; $\times 420$.

Figures 4, 5 Spongaster tetras Ehr., Vitjaz Station 4522; surface sediment.

4. $\times 305$.

5. $\times 760$.

Figure 6 Spongotrochus glacialis Popofsky. Ob Station $285 ; \times 400$.

PLATE 35

Spongotrochus glacialis Popofsky, Ob Station 285; surface sediment

Figure $1 \times 170$; Part of the "gown" is broken.

Figure $2 \times 400$; The main spongy disk up to the center is broken.

Figure 3, 4 A well-preserved specimen, only the spines are broken.

3. $\times 120$.

4. $\times 450$.

Figures 5, 6 The specimen is without the "gown"; $\times 160$

5. $\times 160$.

6. $\times 400$.

(See p. 662) 
PLATE 34

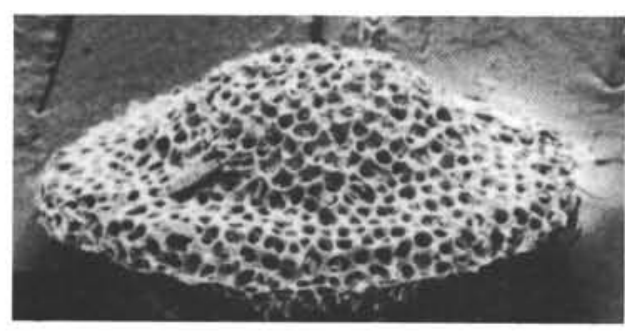

1

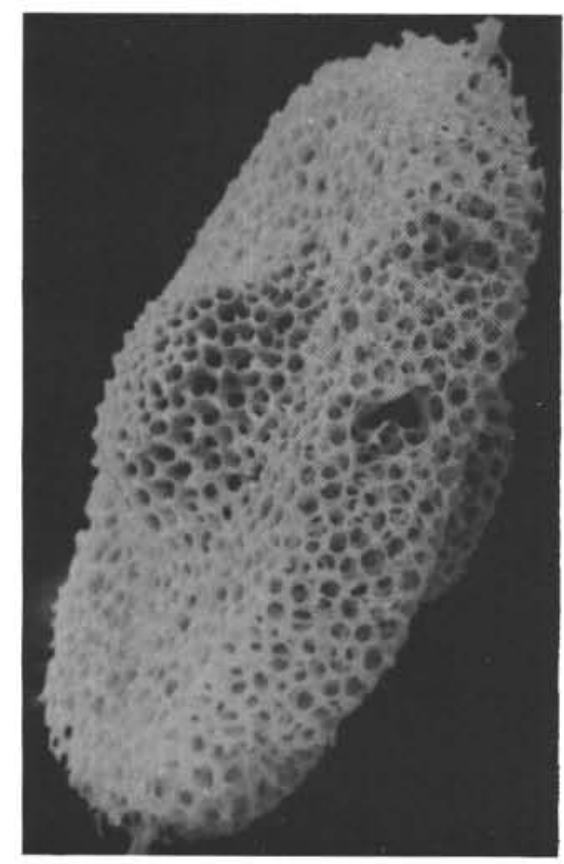

3

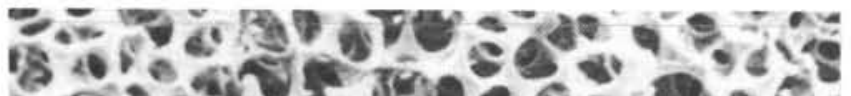

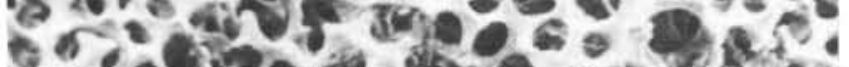

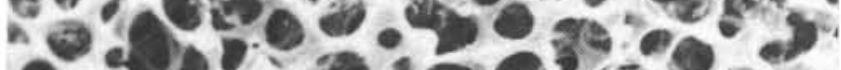

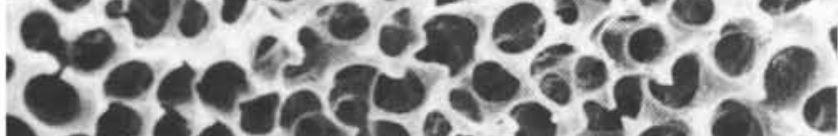

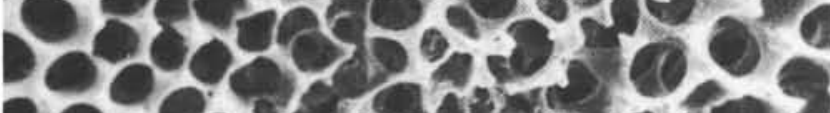

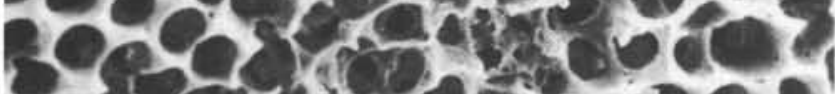

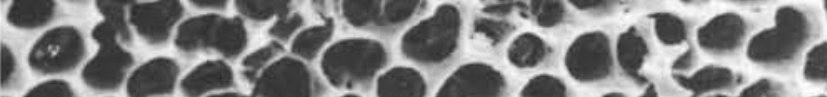

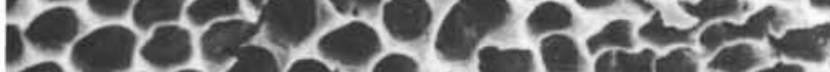

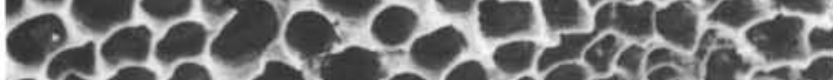

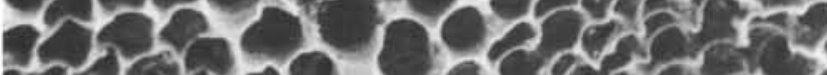

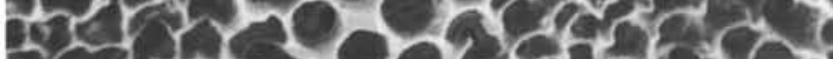

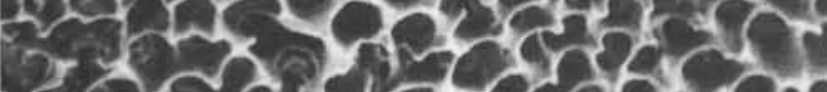

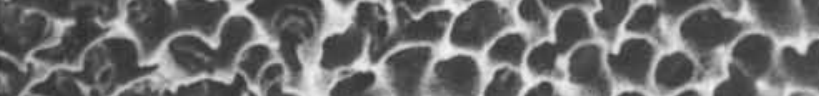
4.9.

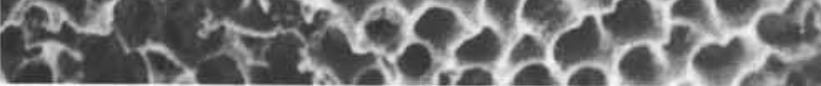

2
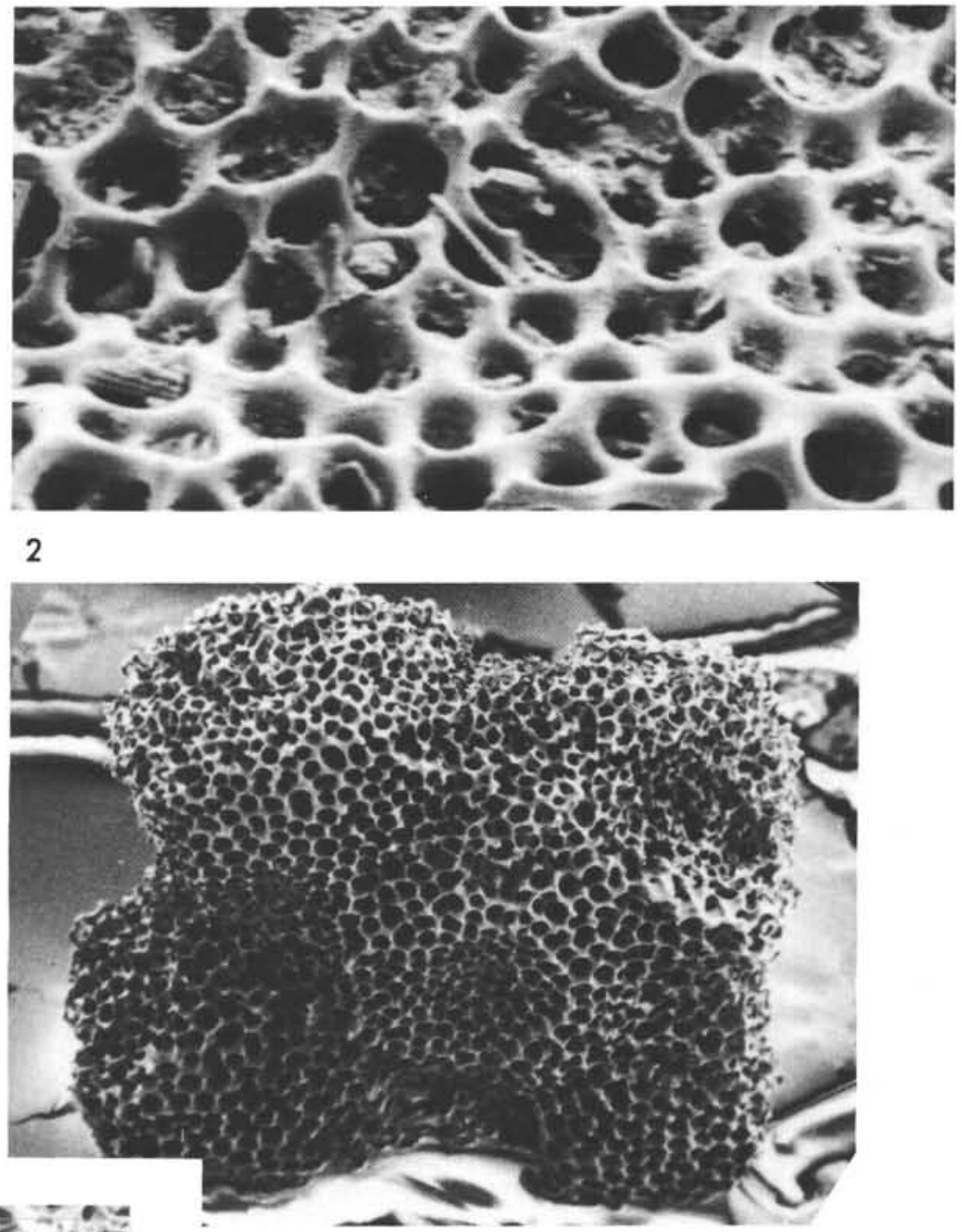

4

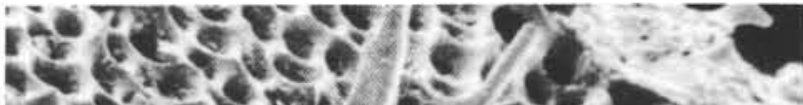

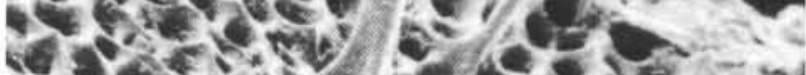
Q. P.

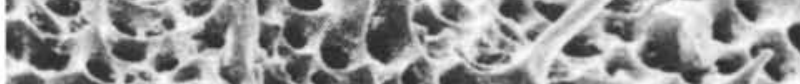

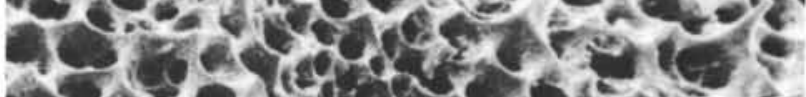

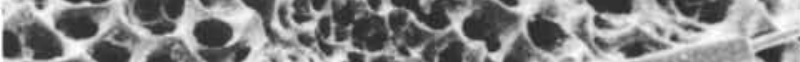

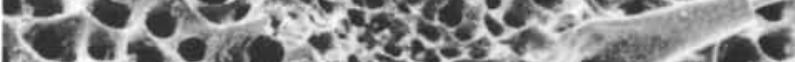

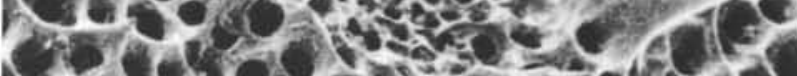

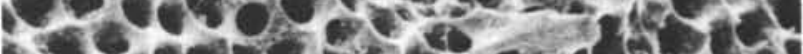

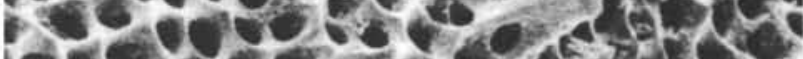

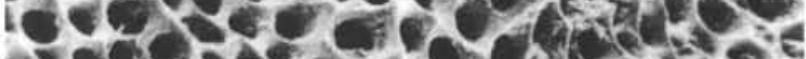

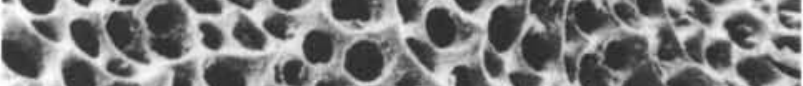

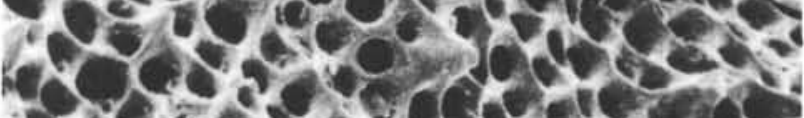

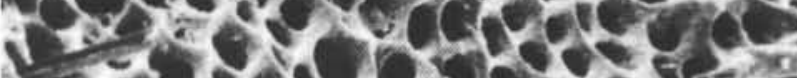

6 
PLATE 35

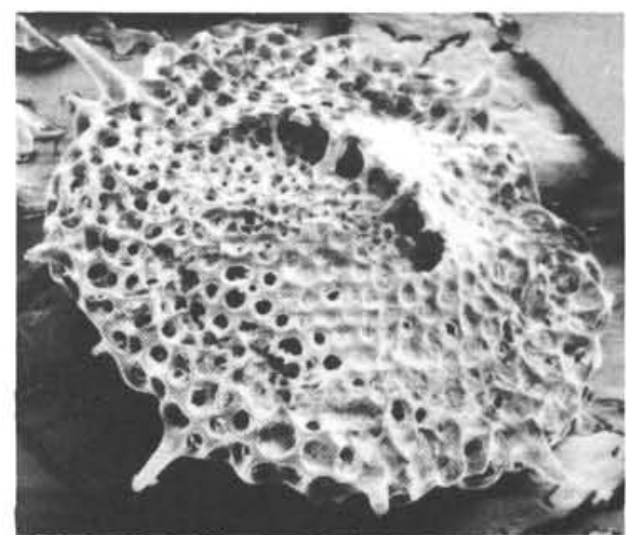

1

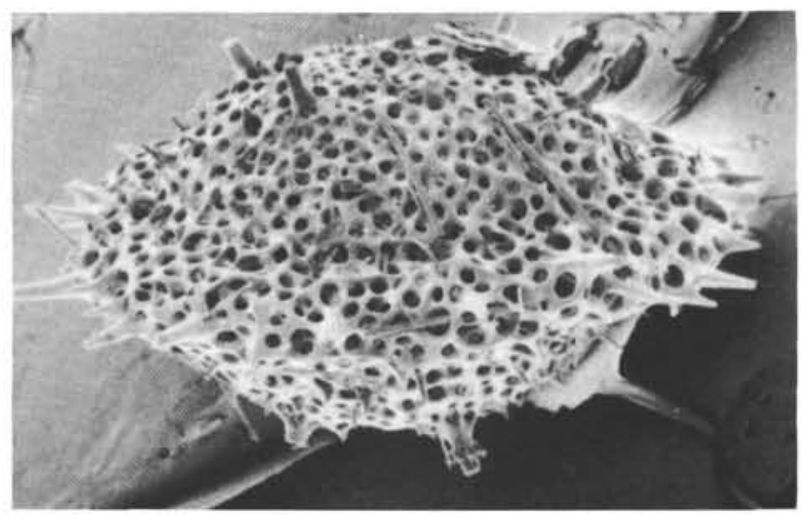

3

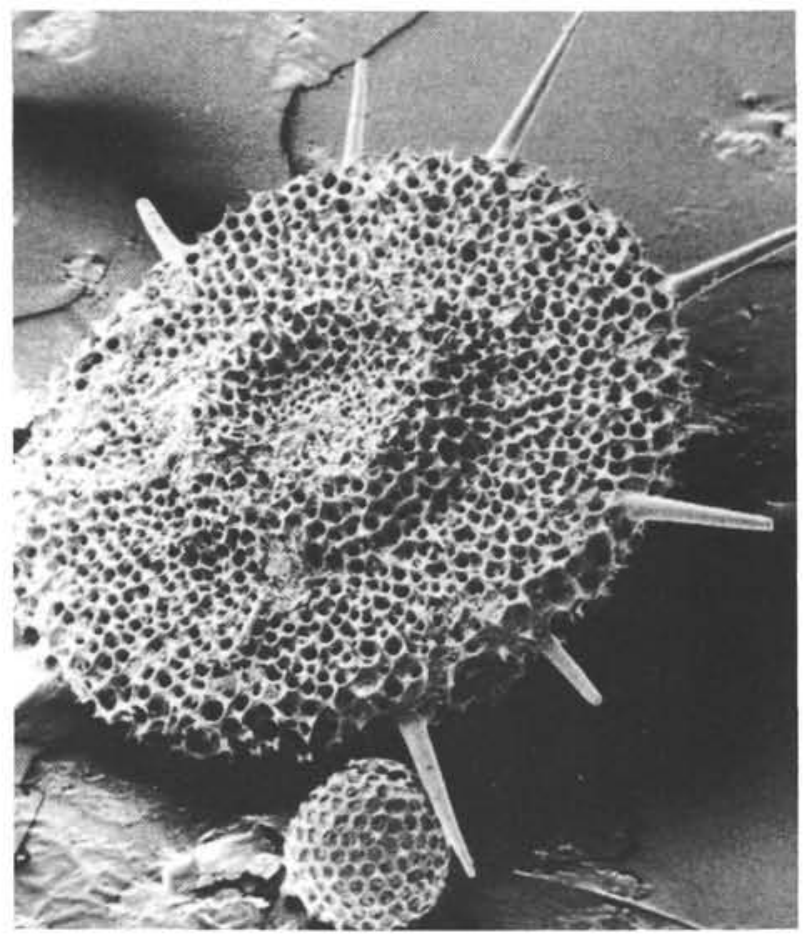

5

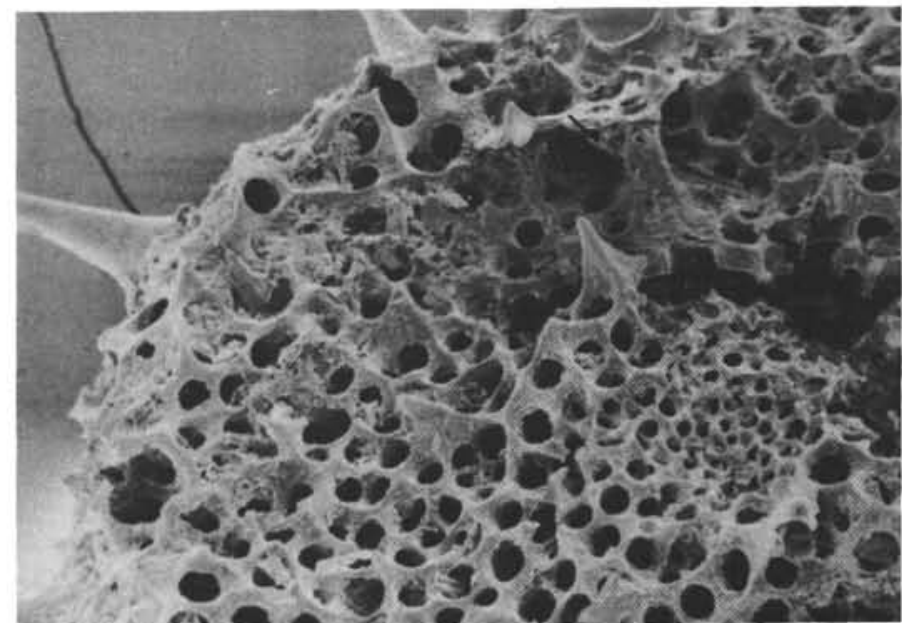

2

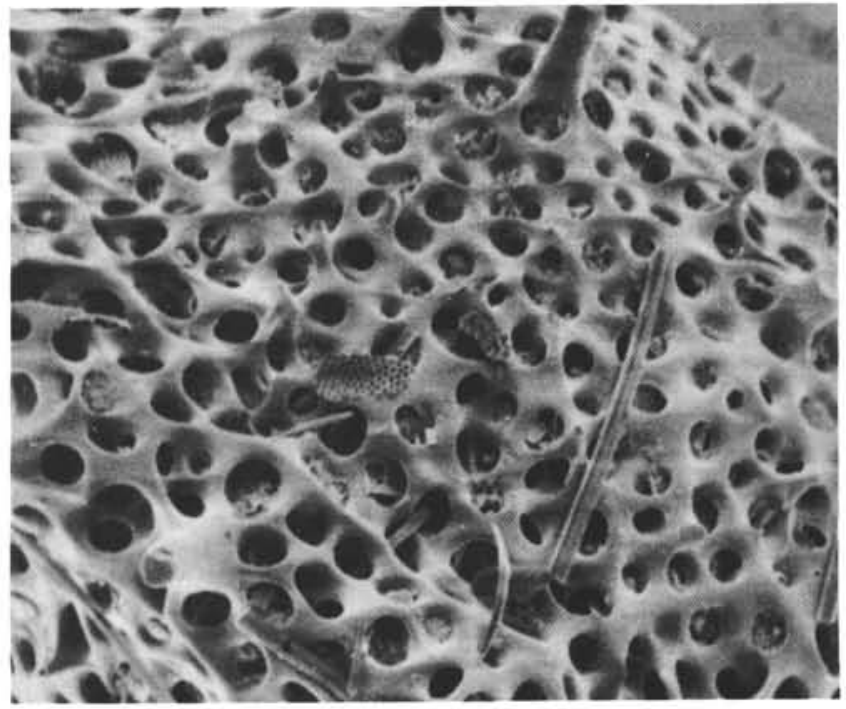

4

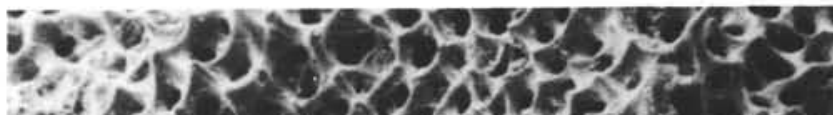

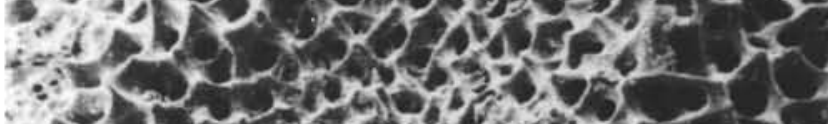

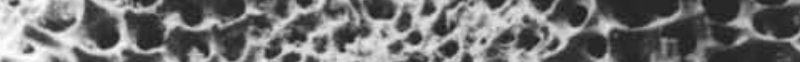

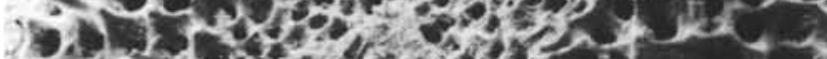

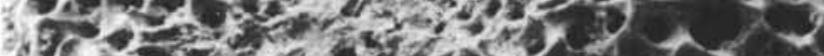

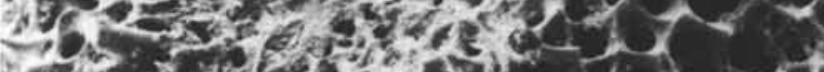

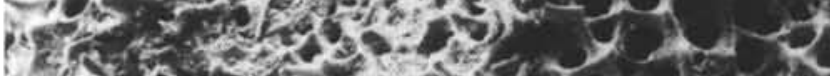

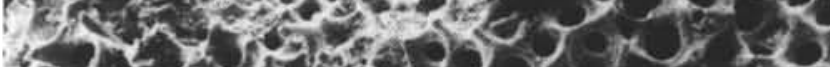

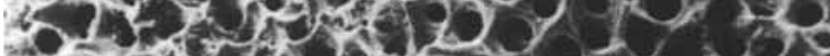
(1)

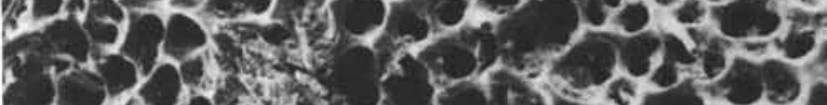

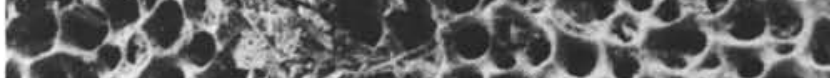

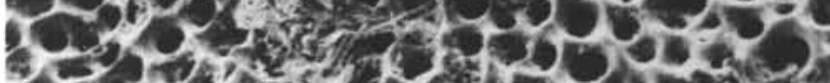

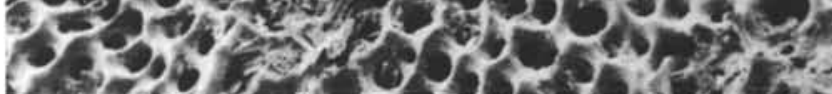


PLATE 36

Figures 1-4 Spongodiscus osculosa (Dreyer) Ob Station 285; surface sediment.

1. The specimen is covered with "gown" $\times 400$.

2. The specimen is without "gown" in the central part; $\times 450$; pylom tube can be seen.

3. The same; $\times 900$.

4. Specimen with broken "gown"; The pylom can be seen; $\times 420$.

Figure $5 \quad$ Rhopalastrum profundum (Ehrenberg). Vitjaz Station 4522; surface sediment; $\times 225$; Both pseudoaulophacoid and spongy structures are seen.

Figure $6 \quad$ Euchitonia mulleri. Vitjaz 4522; surface sediment; Central part covered with poreless plate, surrounded by pseudoaulophacoid structure; distal ends of arms are spongy; $\times 440$.

(See p. 664)

\section{PLATE 37}

Figures 1, 2 Amphimenium ? splendriarmatum Clark and Campbell group. 29-278-27-3.

1. $\times 270$.

2. $\times 670$.

Figure 3 Amphymenium ? splendriarmatum Clark and Campbell. 29-280A-6, CC; $\times 240$.

Figures 4, 5 Ommatogramma dumitrikai n. sp. 29-278-27-3.

4. $\times 270$.

5. $\times 680$.

Figure $6 \quad$ Spongurus ? bilobatus Clark and Campbell group. 21-208-28, CC; Eocene; $\times 380$.

Figure $7 \quad$ Spongurus ? pylomaticus Riedel. $\mathrm{Ob}$ Station 181; $\times 470$; spongy meshwork of the pylom is seen; radial spines broken and "gown" is not quite clean.

(See p. 665) 


\section{PLATE 36}

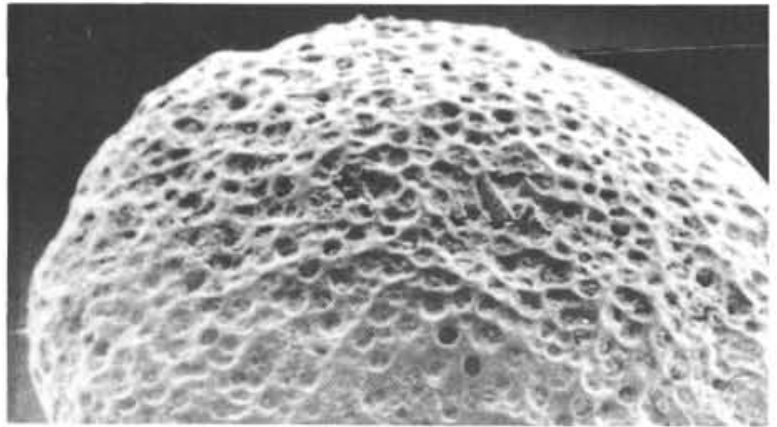

1

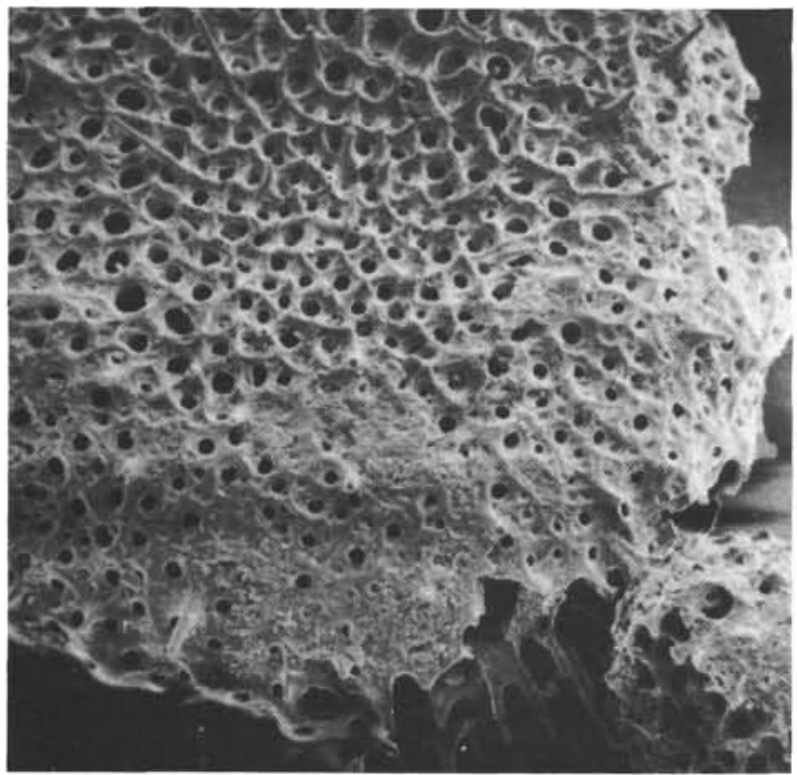

2

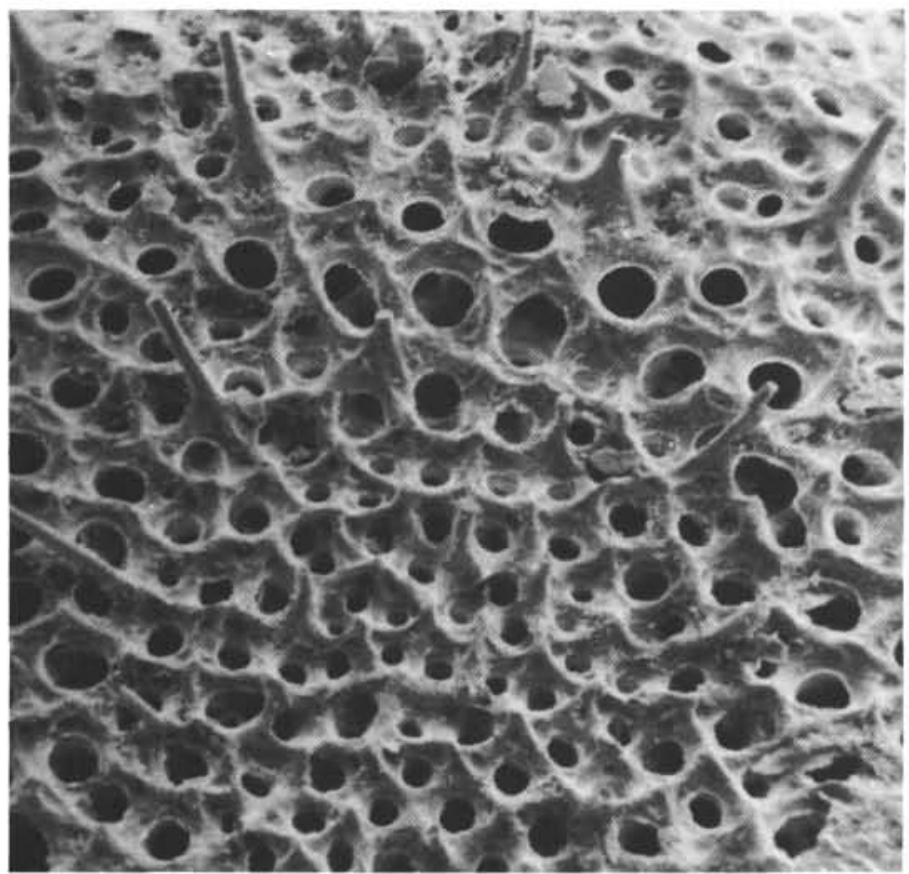

3

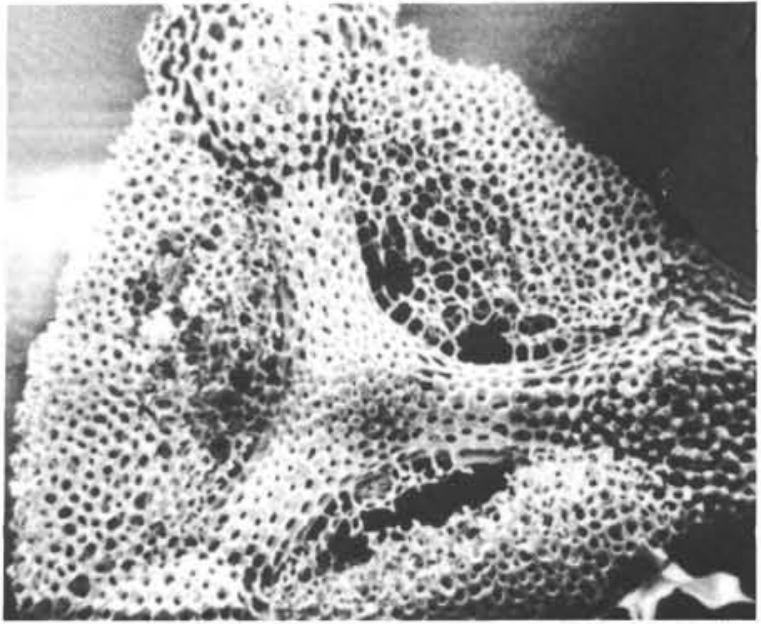

5

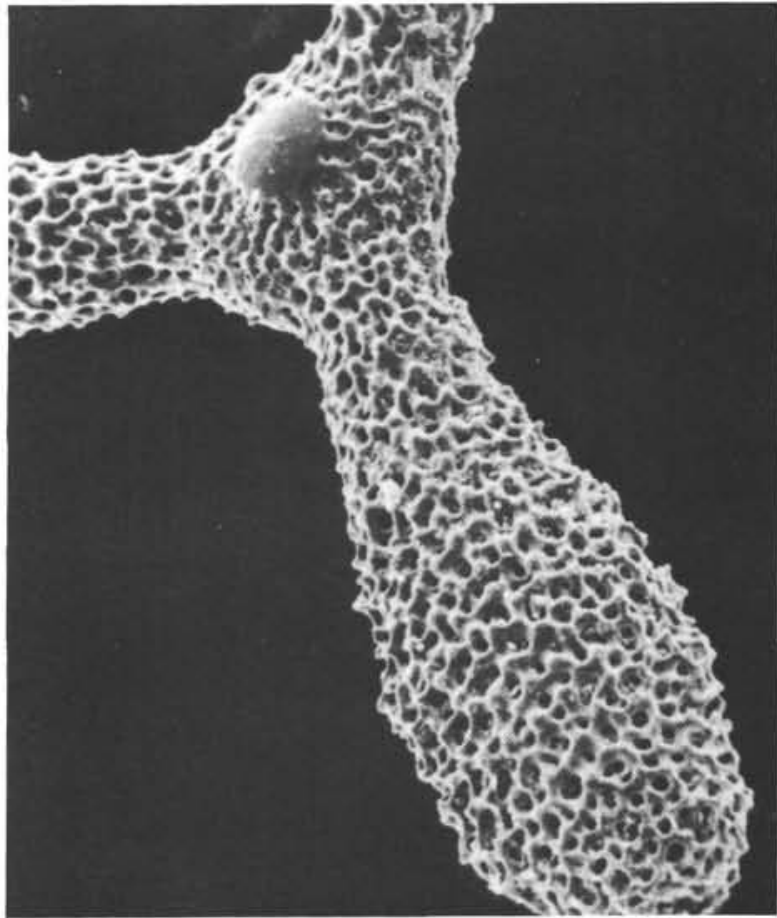

6

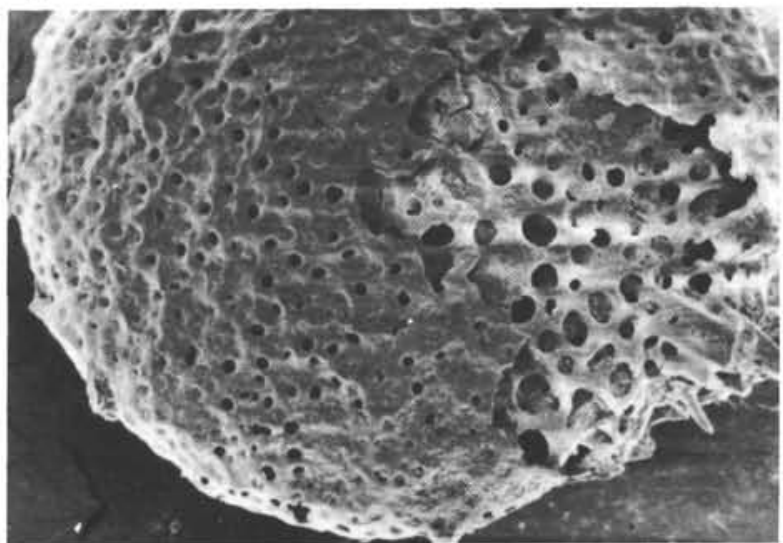

4 


\section{PLATE 37}

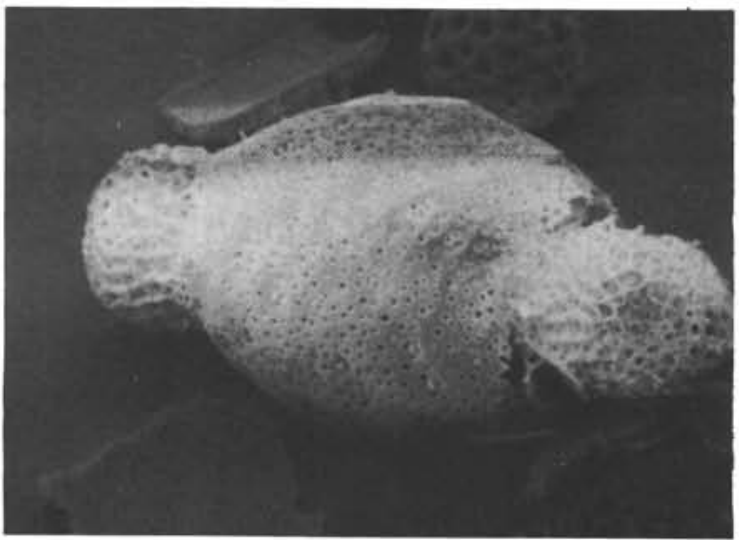

4

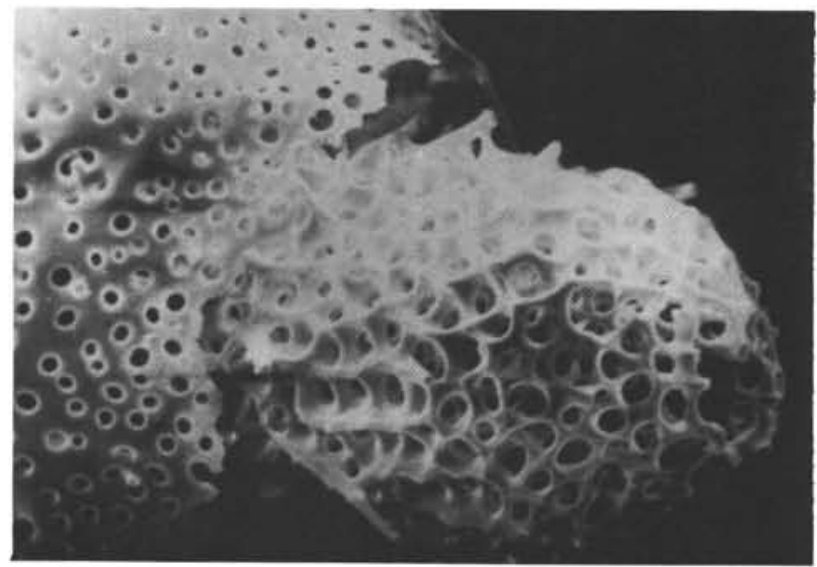

5
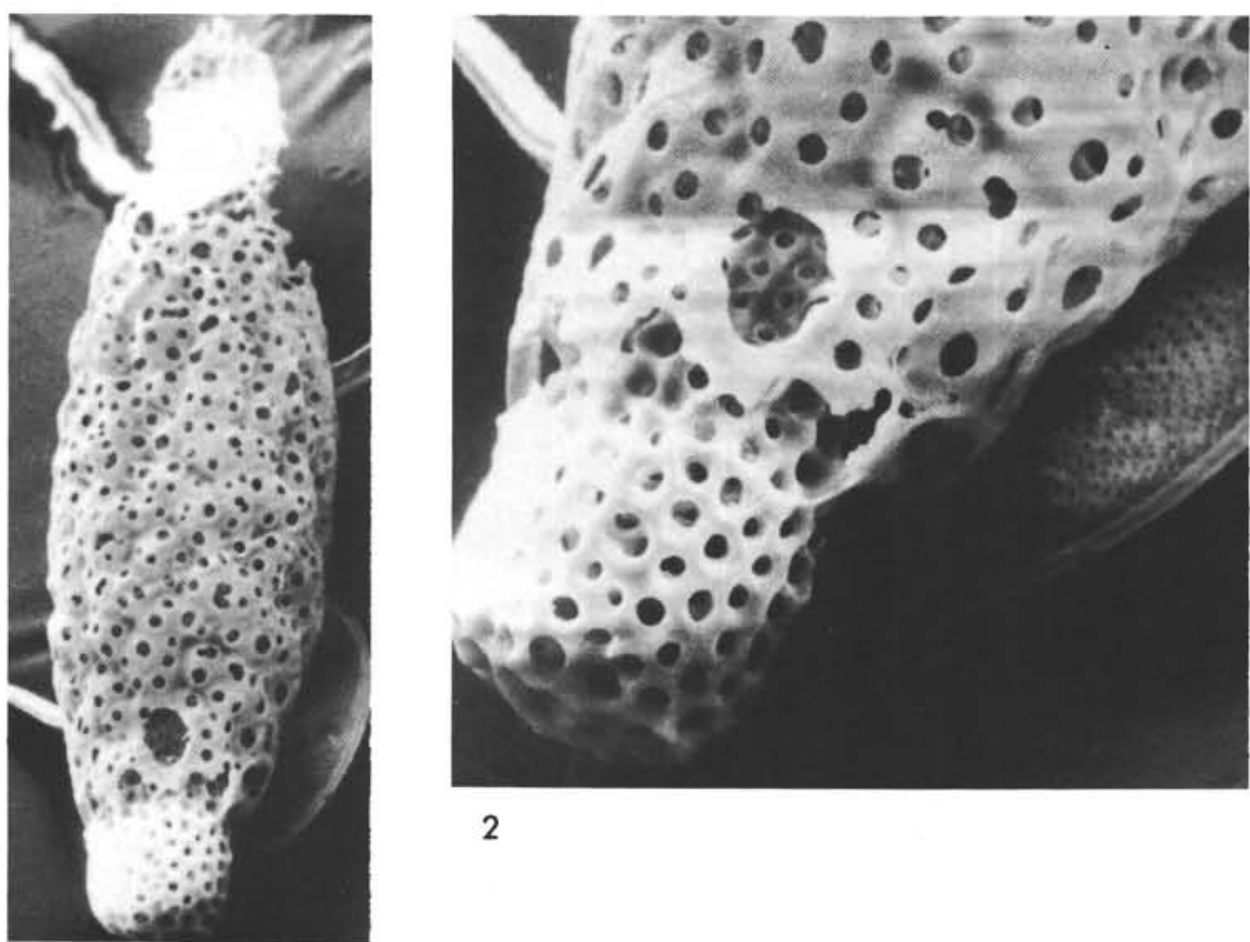

2

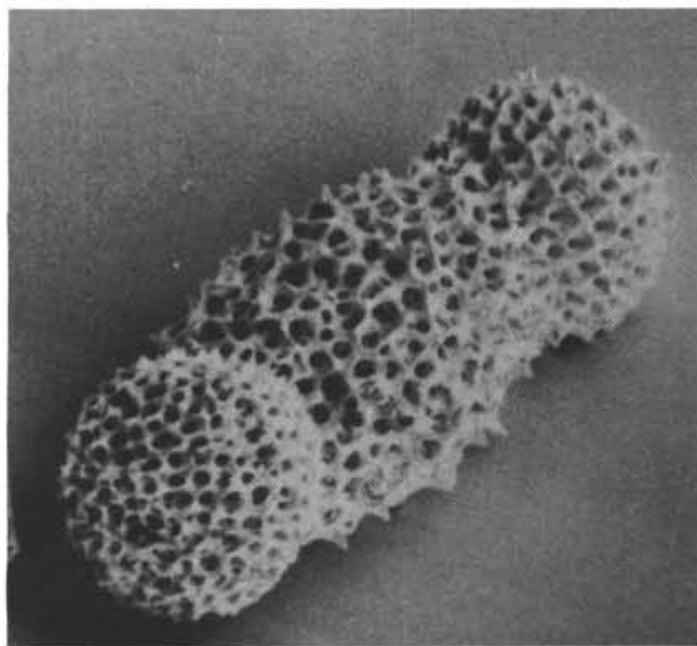

6

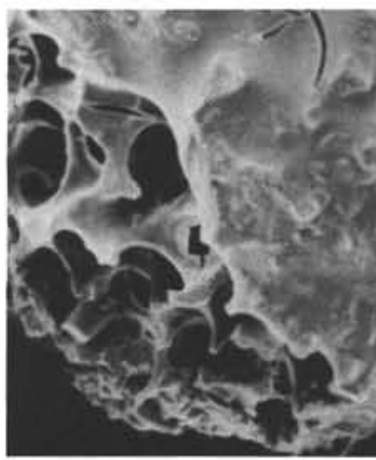

7

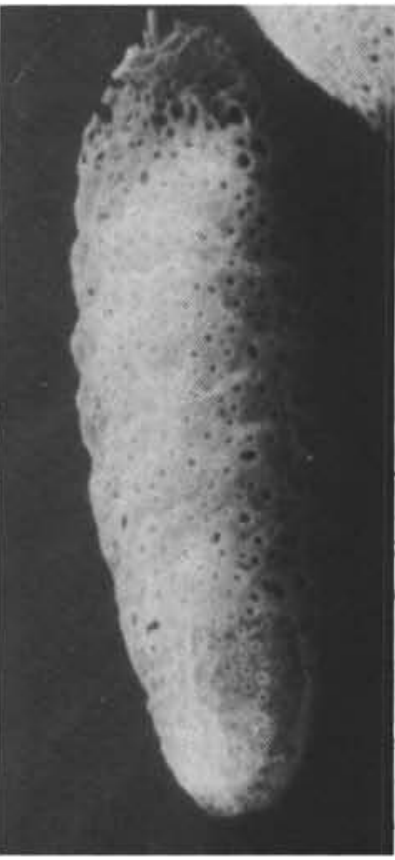

3 
PLATE 38

Schizodiscus codrant n. sp.

Figures 1-3 29-278-27-3.

1. $\times 260$; gown broken, radial spines are seen in center.

2. $\times 1350$; central part of another specimen; radial spines are broken.

3. $\times 255$. Specimen with a "gown."

Figure $4 \times 170 ; 29-280 \mathrm{~A}-6, \mathrm{CC}$.

Figures 5, 6 29-278-27-3.

5 . $\times 275$; preserved radial spines.

6 . $\times 680$; part of the "gown" is broken; radial spines are seen.

Figure $729-278-27-3 ; \times 260$; no radial spines or "gown" are seen.

PLATE 39

Figures 1-4 Perichlamidium limbatum Ehrenberg. 29-280A-6, CC.

1. $\times 200$.

2. $\times 190$.

3. $\times 440$.

4. $\times 930$.

Figures 5, 6 Octodendron sp. 29-280A-6, CC

5. $\times 185$; Part of the shell and all outer spines are broken.

6. $\times 100$.

(See p. 668) 


\section{PLATE 38}
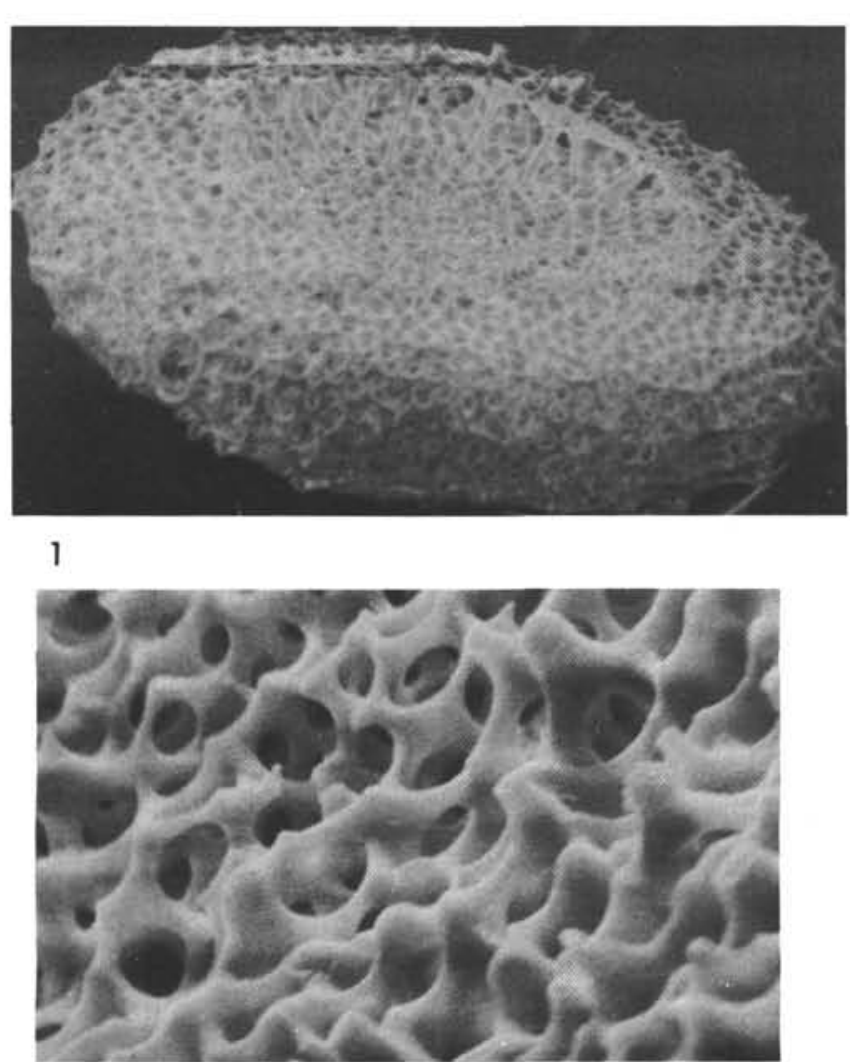

2

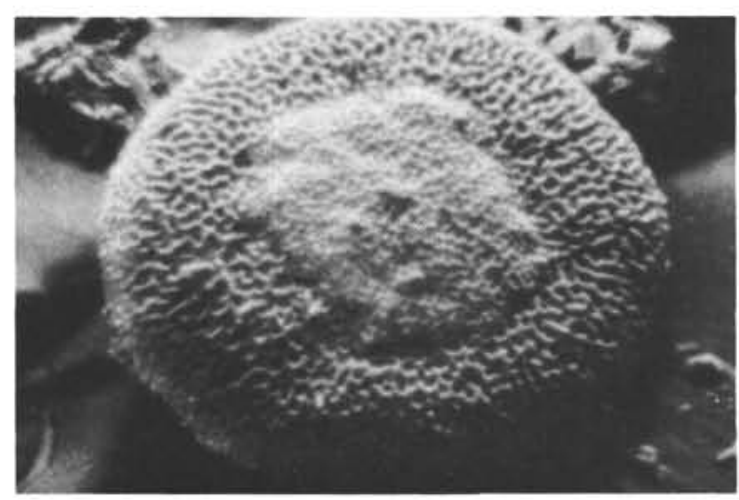

3

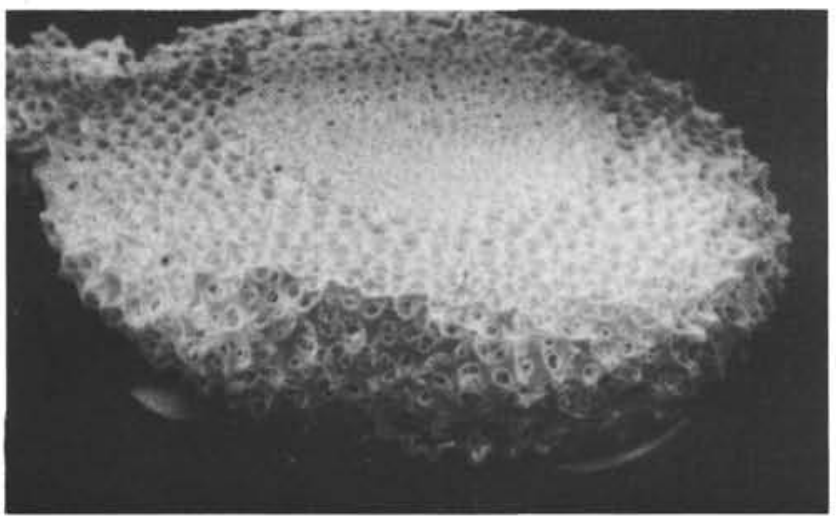

4

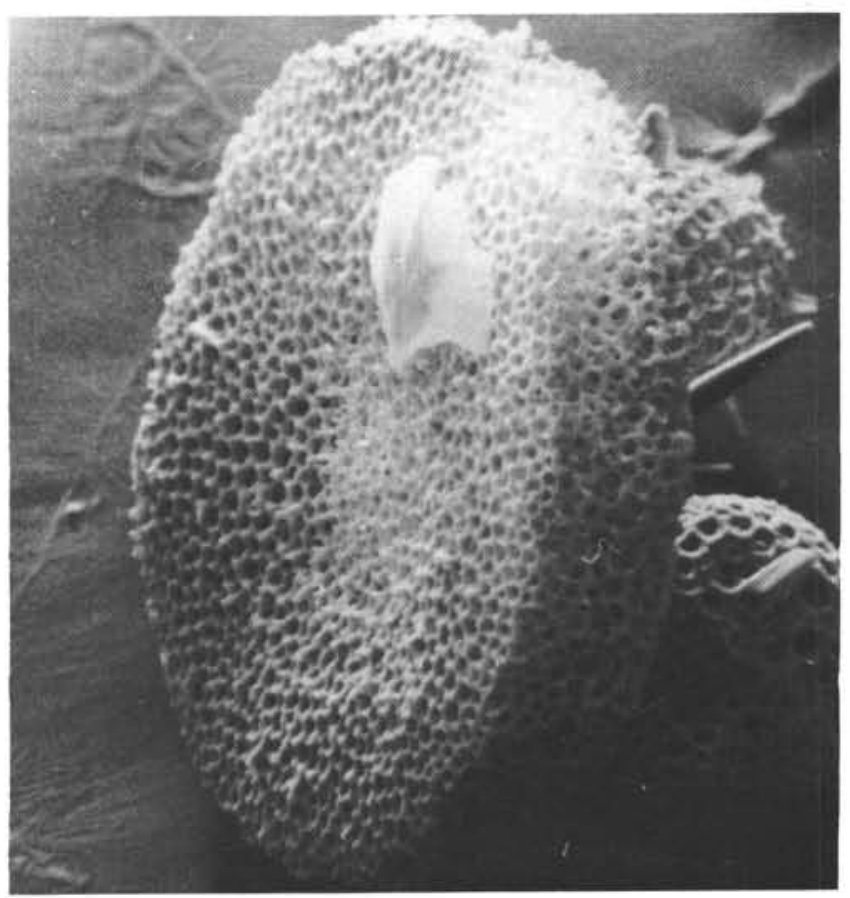

7

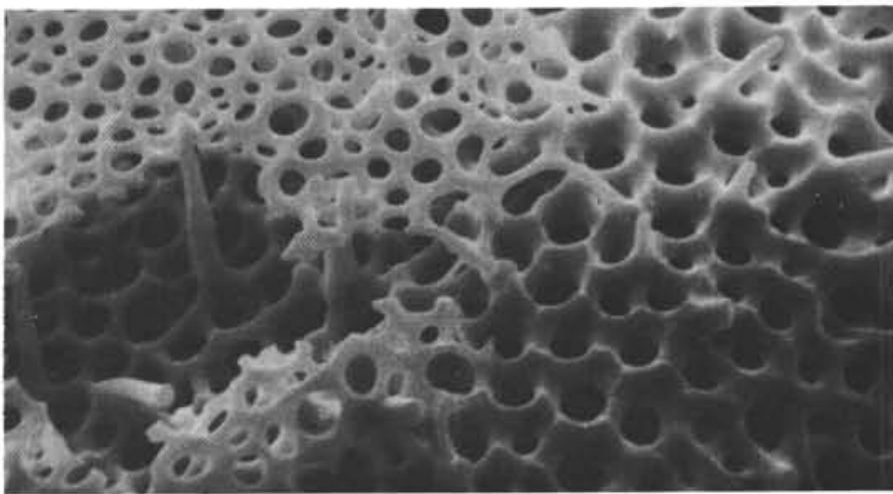

6

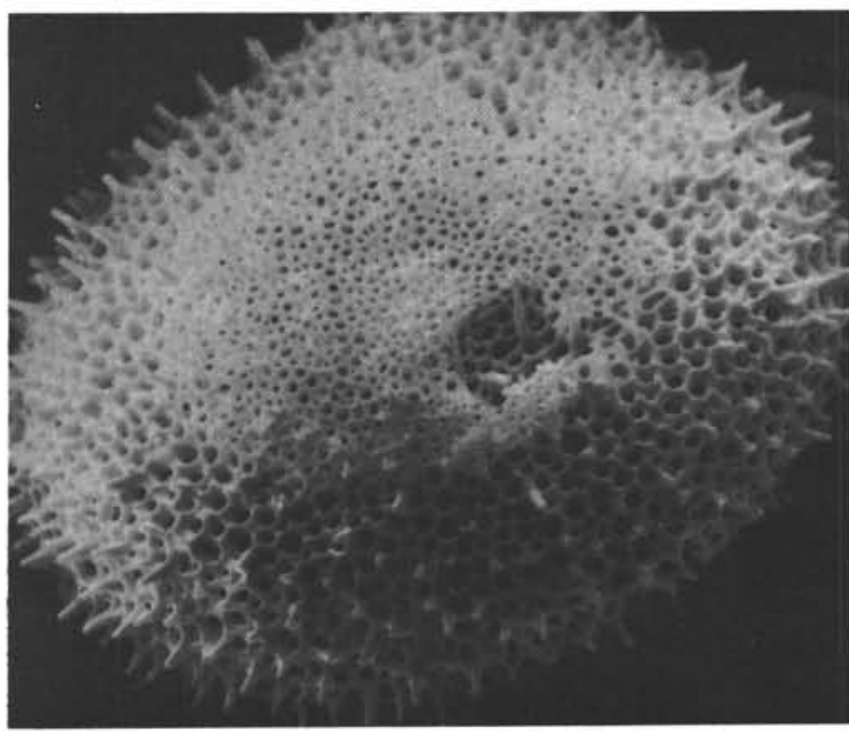

5 
PLATE 39

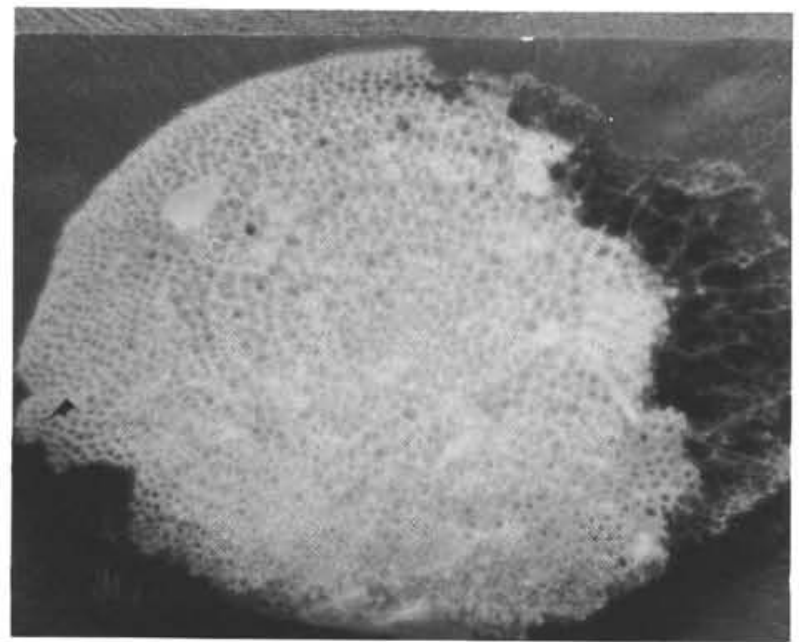

1

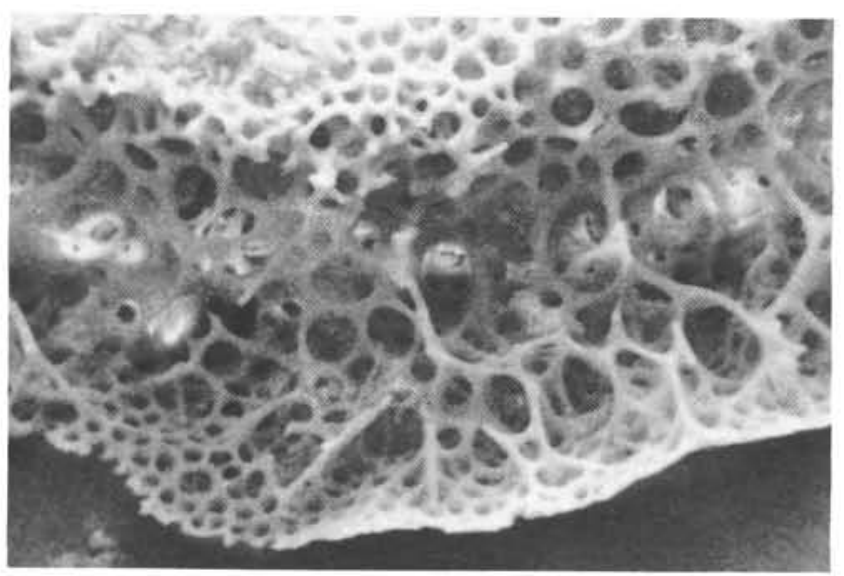

3

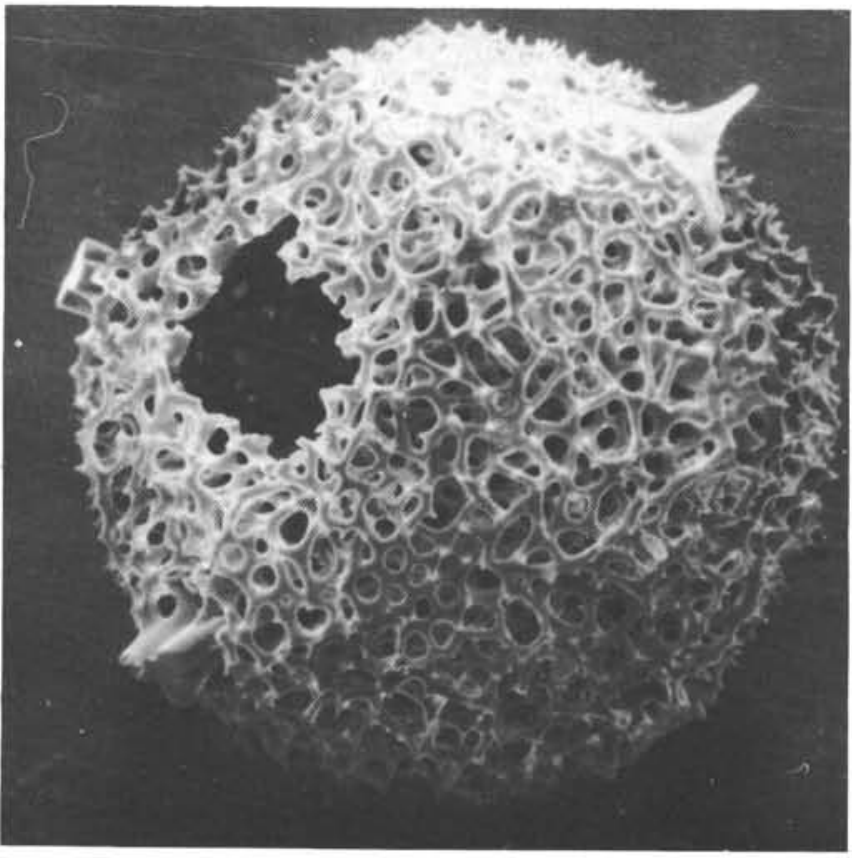

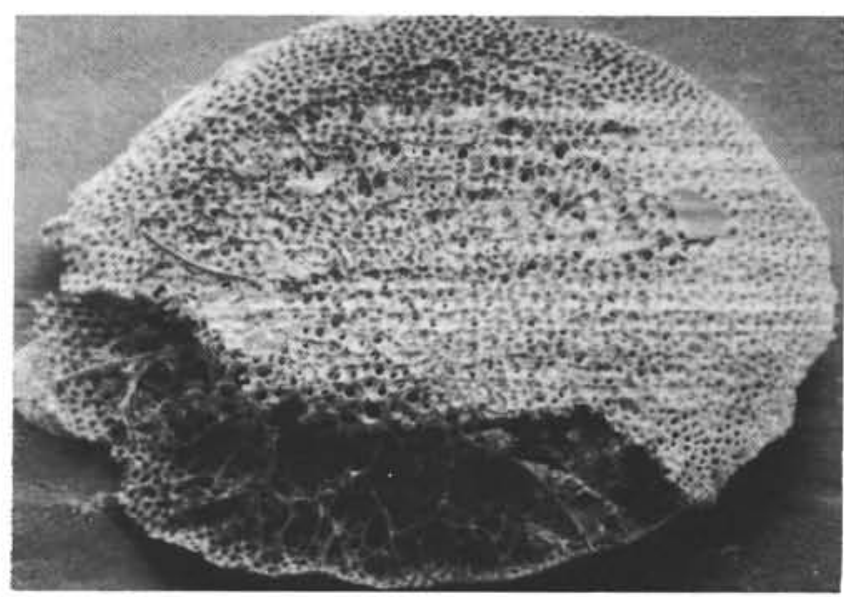

2

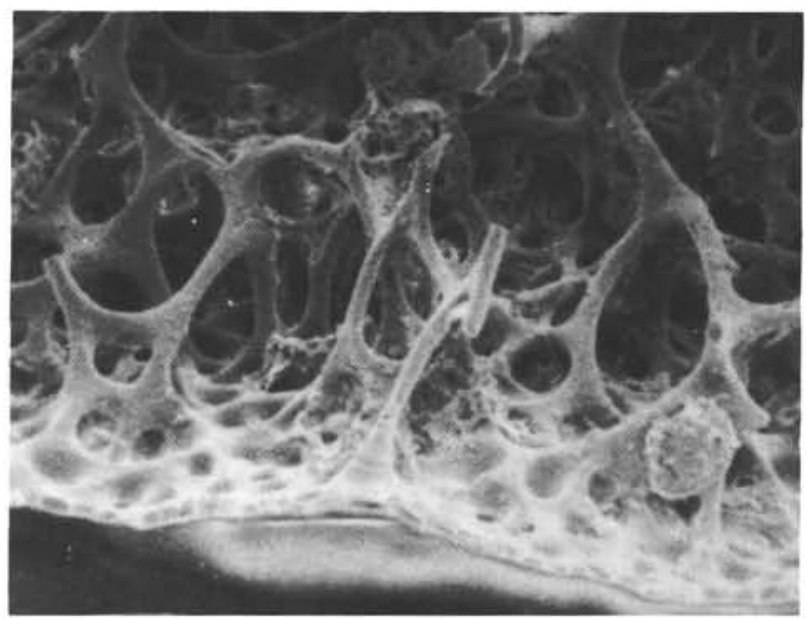

4

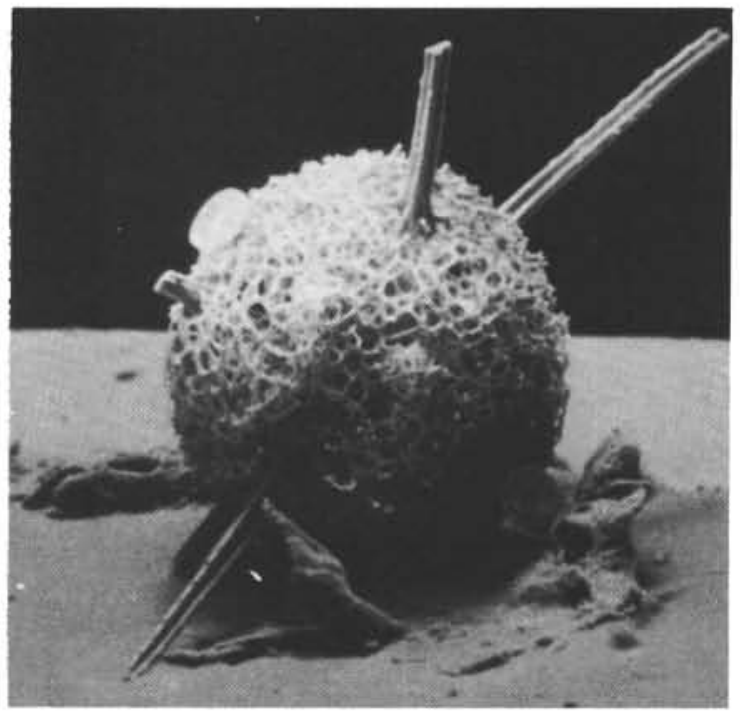

6 
PLATE 40

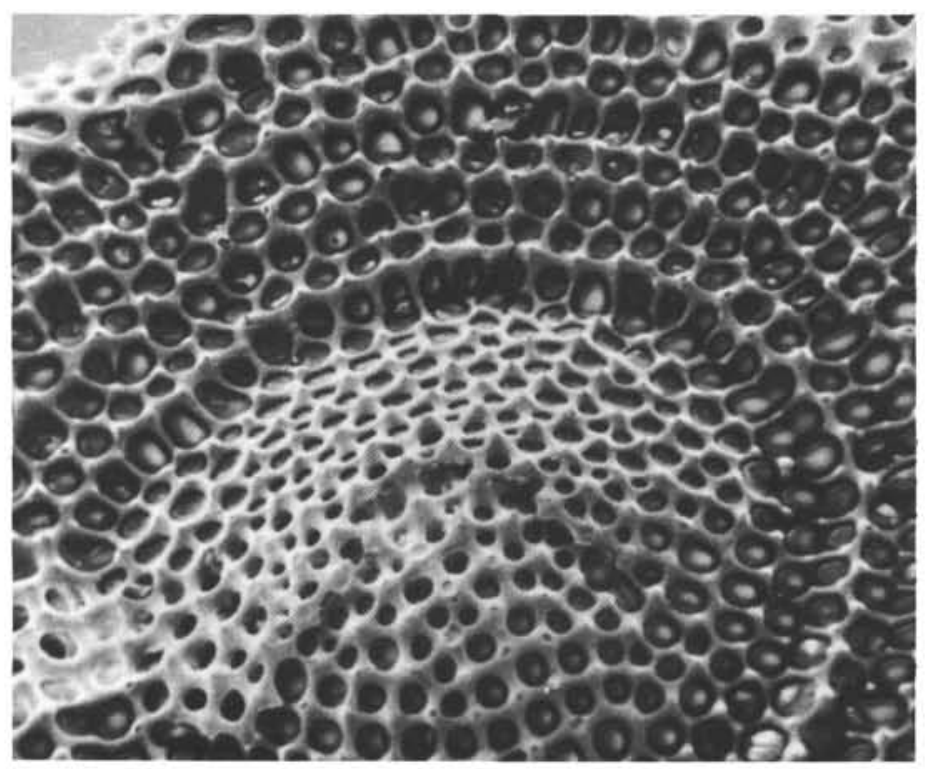

1

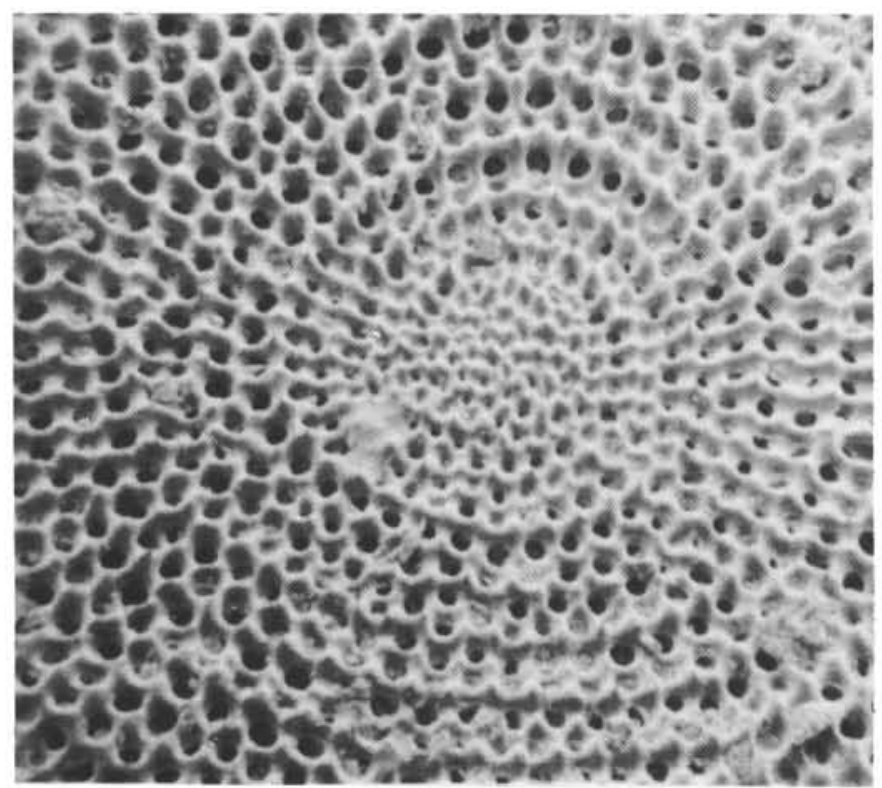

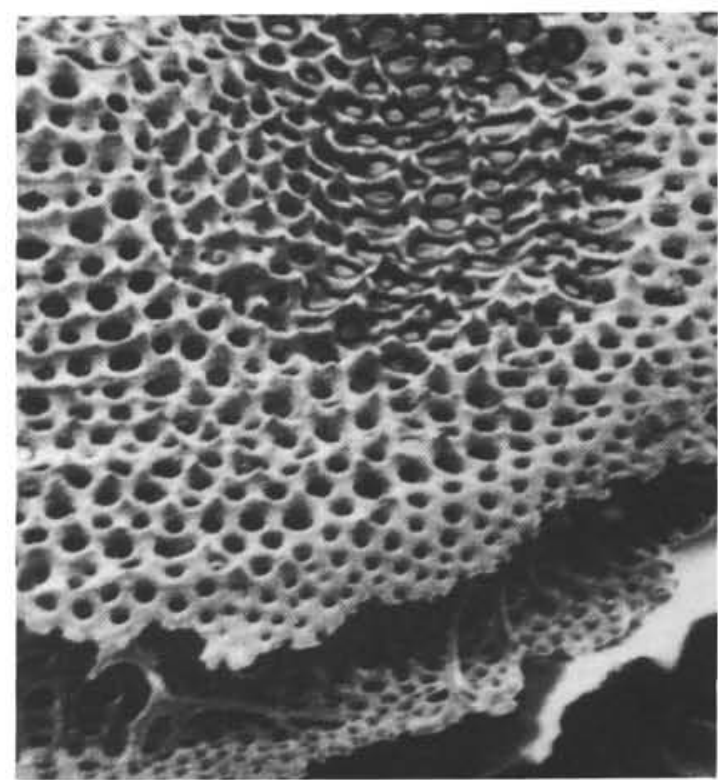

2

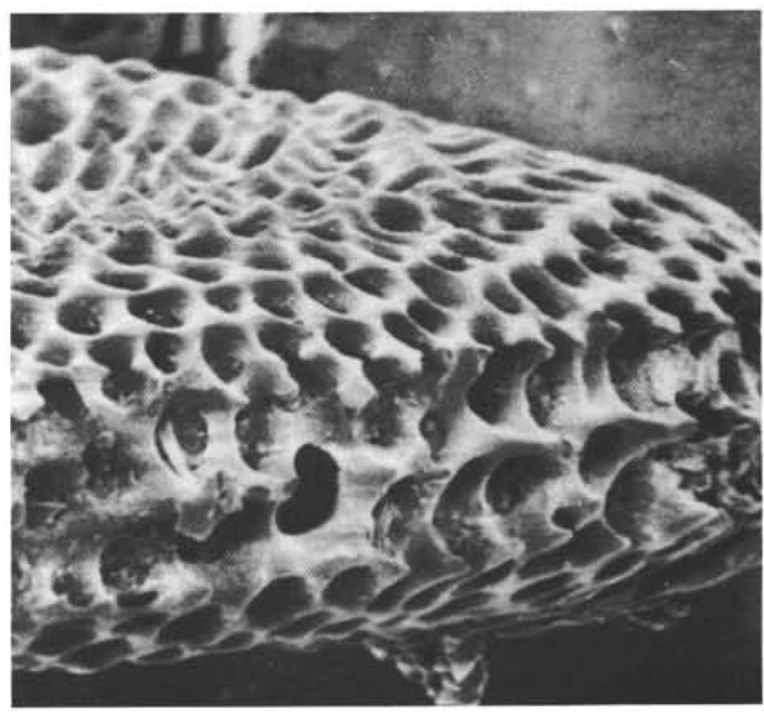

4

Vitjaz Station 4522; surface sediment.

Figures 1, 2 Perichlamidium sp.

1. $\times 580$; pseudoaulophacoid structure.

2. $\times 550$; marginal plates and internal spongy meshwork.

Figures 3, 4 Stylodictya sp.

3. $\times 410$.

4. $\times 950$; porodiscid arrangement is seen. 


\section{PLATE 41}

Figures 1-5 Lithomitra sp. B, 29-280A-6, CC.

1. $\times 570$.

2. $\times 550$.

3. $\times 1200$; upper part of shell and tube on cephalis can be seen.

4. $\times 2300$; wall of same specimen as Figure 1 .

5. $\times 2400$; wall of same specimen as Figure 2; pores are bigger; some parts are corroded.

Figures 6,7 Calocyclas ? semipolita Clark and Campbell group. 29-280-6, CC.

6. $\times 200$.

7. $\times 1100$.

Figure $8 \quad$ Podocyrtis sp. 29-208-28, CC; Eocene; $\times 400$.

PLATE 42

Figures 1, 2 Diplocyclas sp. 29-278-23-3.

1. $\times 1800$; spine Vert is four-edged.

2. $\times 450$; pores are irregular.

Figure 3 Eucyrtidium (?) biauritum Ehrenberg. 21-208-28, $\mathrm{CC}$; Eocene $\times 830$; pores as long funnels.

Figure 4 Clathrocyclas universas group. 21-209-43-5; Russian Eocene; Collection of S. Totchilina; $\times 970$; Spines $\mathrm{A}$ and $\mathrm{L}$ are seen.

Figure 5 Clathrocyclas universa (?) Clark and Campbell group. $\times 400$; cephalo-tube is seen in place of spine Vert. (Compare Plate 15, Figures 15, 16).

(See p. 672) 
PLATE 41

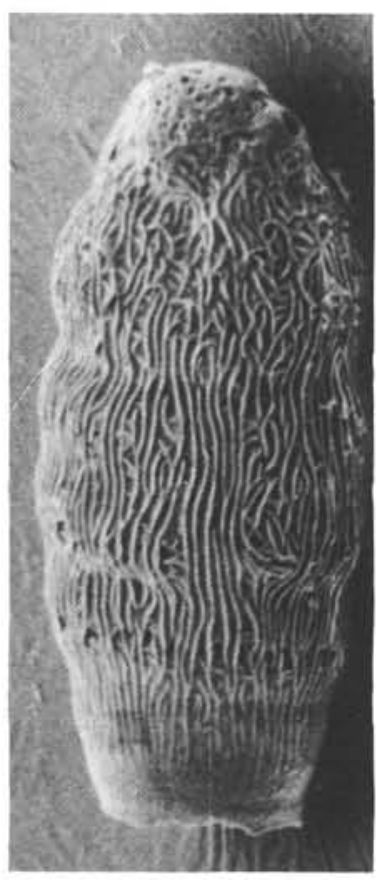

1

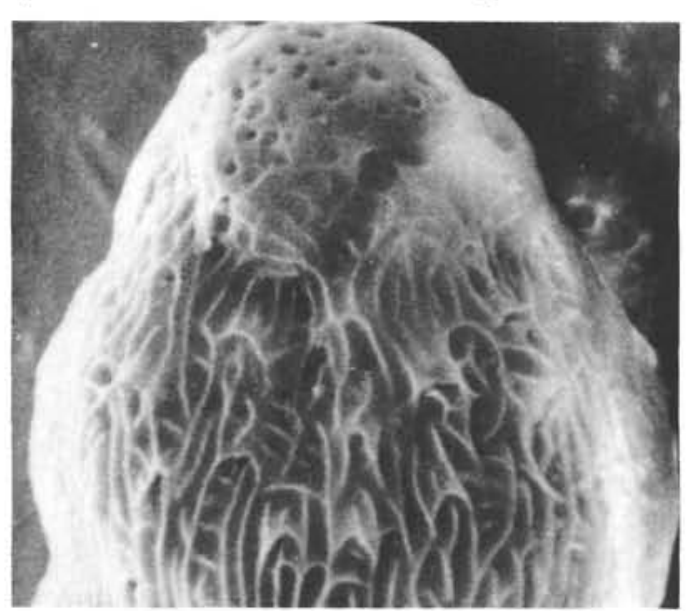

3

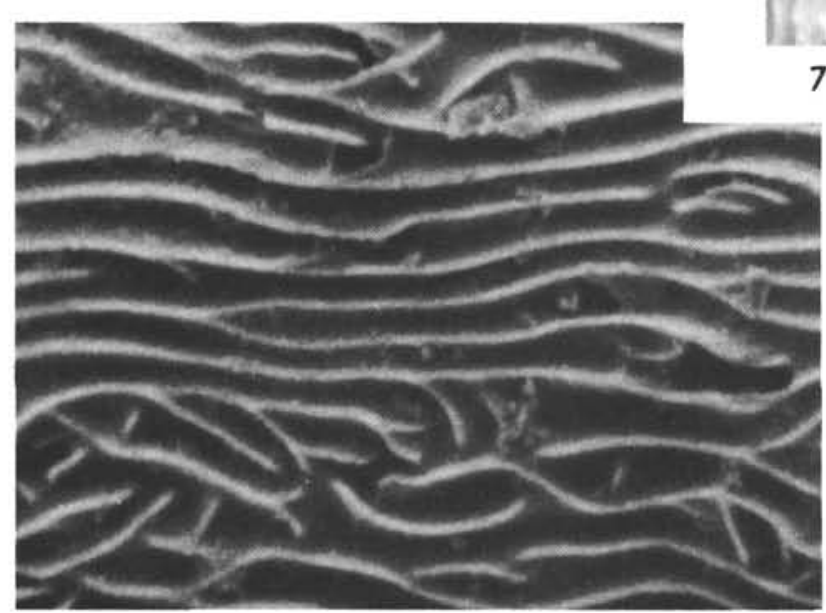

4

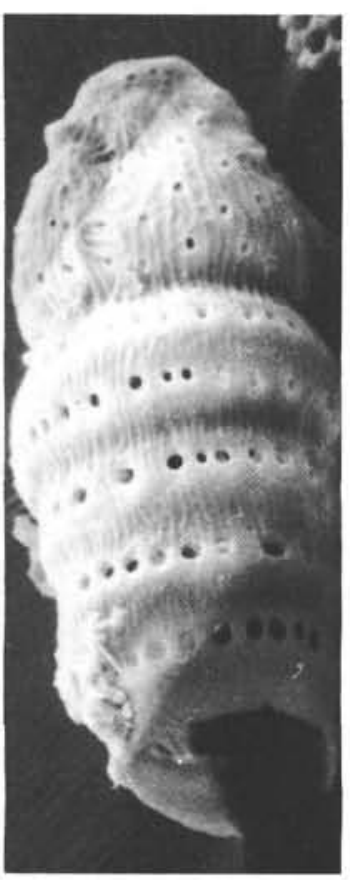

2
7

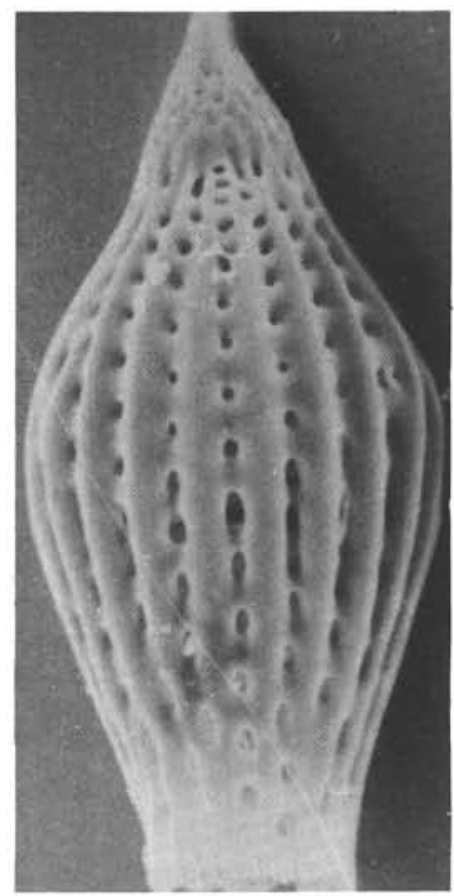

8

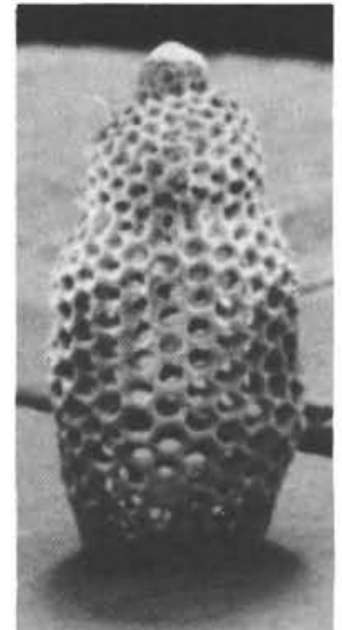

6
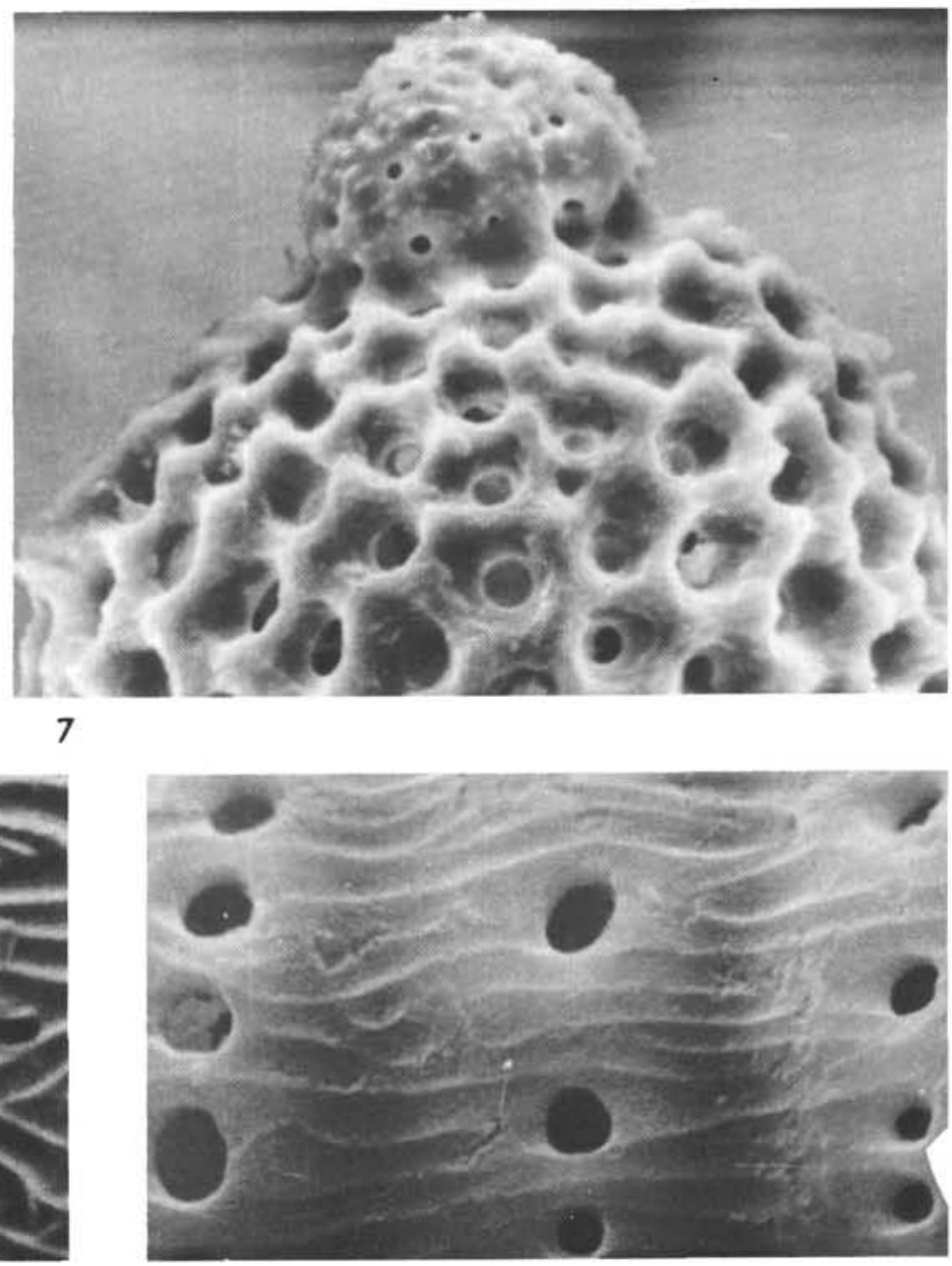

5 
PLATE 42
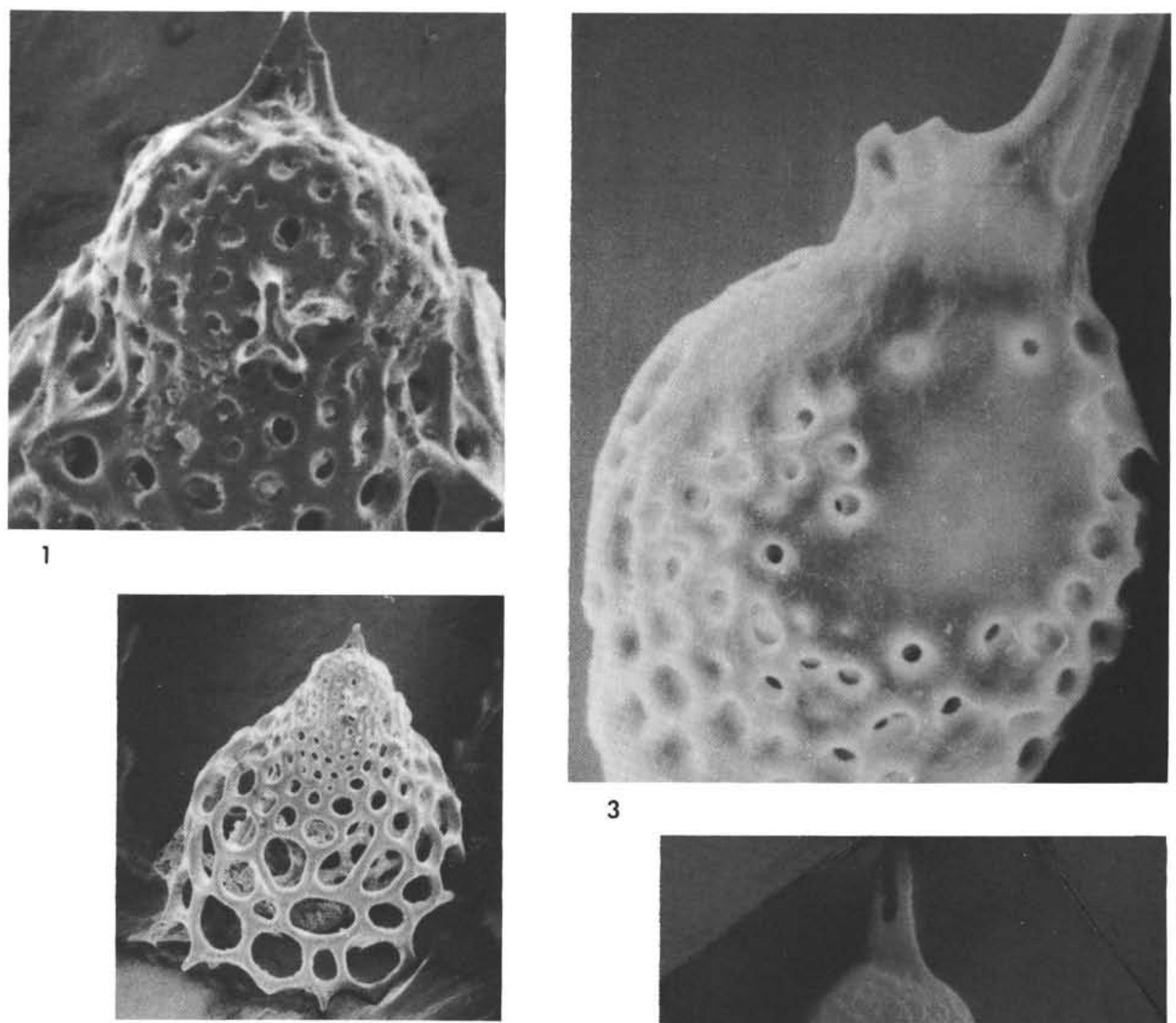

3

2

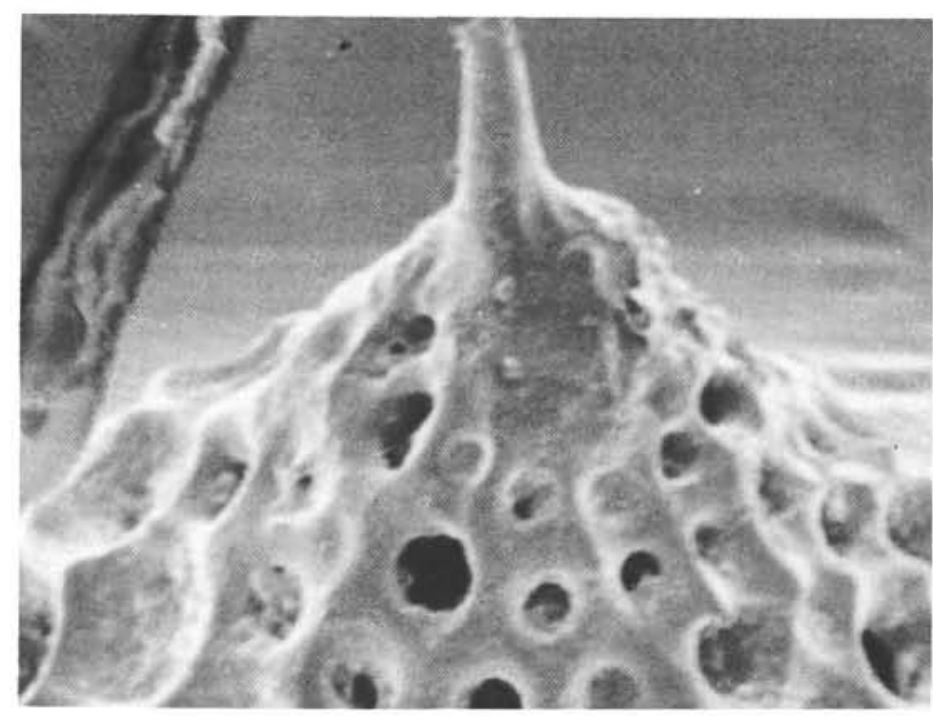

4

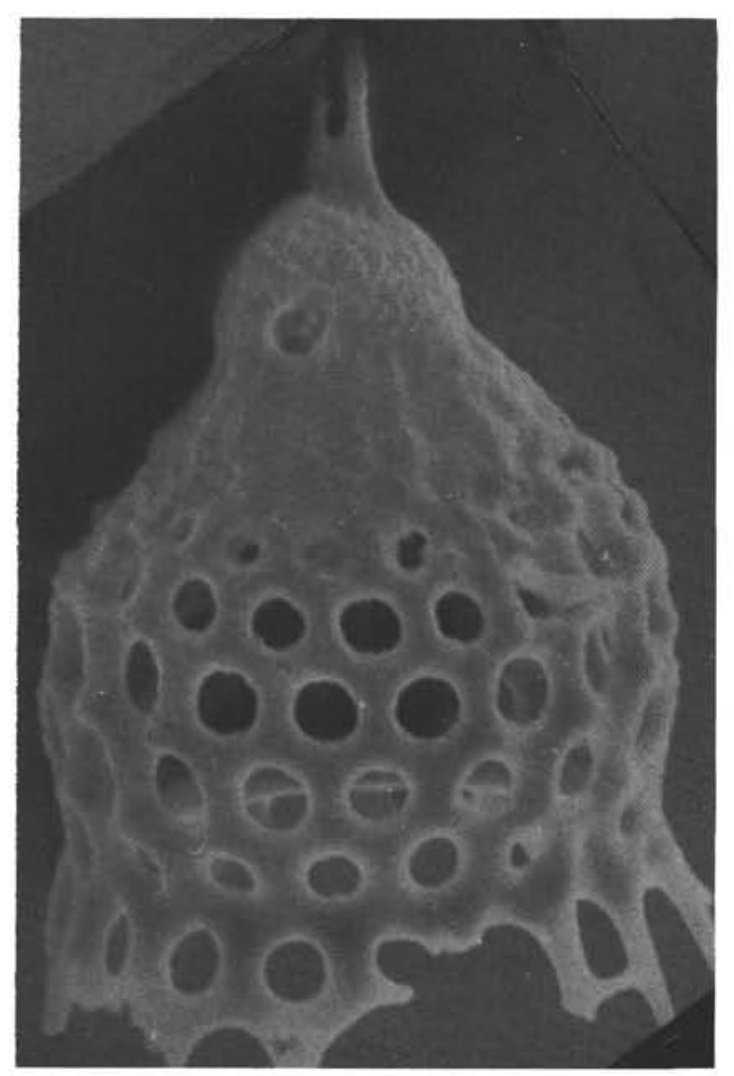




\section{PLATE 43}

Figures 1, 2 Clathrocyclas humerus $\mathrm{n} . \mathrm{sp}$.

1. 29-278-27-3; $\times 240$.

2. 29-278-23-3; $\times 450$.

Figures 3-5 Archipilium sp.
3. $\times 460$.
4. $\times 500$; distal parts of feet have pores.
5. $\times 5000$; feet are hollow inside.

Figures 6, 7 Clathrocyclas universus Clark and Campbell Russian Eocene; Core 209, 43 m; S. Totchilina collection

6. $\times 490$.

7. $\times 950$; plate closing the shell has a peculiar structure.

(See p. 674)

\section{PLATE 44}

Figures 1, 2 Cystophormis brevispina (Vinassa) group. 29-27823-3.

1. $\times 540$; decorated pores.

2. $\times 2150$; the walls of the pylom.

Figure 3 Lithomelissa sp. aff. L. haeckeli Bütschli. 29-280A$6, \mathrm{CC} ; \times 700$.

Figure 4 Ceratocyrtis amplus (Popofsky) group. 29-278-27$3 ; \times 530$.

Figures 5, 6 Peripyramis circumtexta Haeckel group.

5. Ancestral form; 29-280A-3-4; $\times 570$.

6. Recent; typical form; $O b$ Station 285 ; surface sediment; $\times 500$.

(See p. 675) 


\section{PLATE 43}
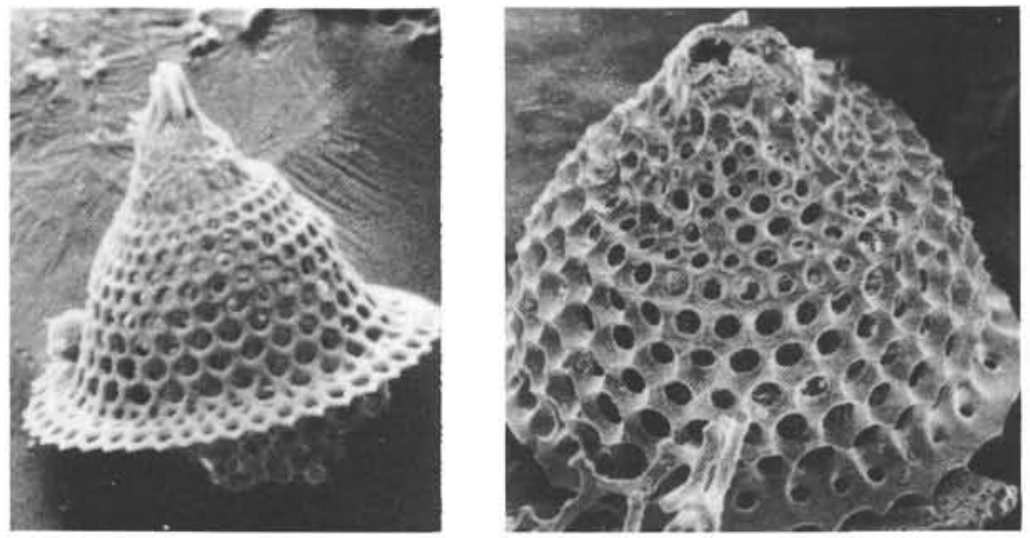

1

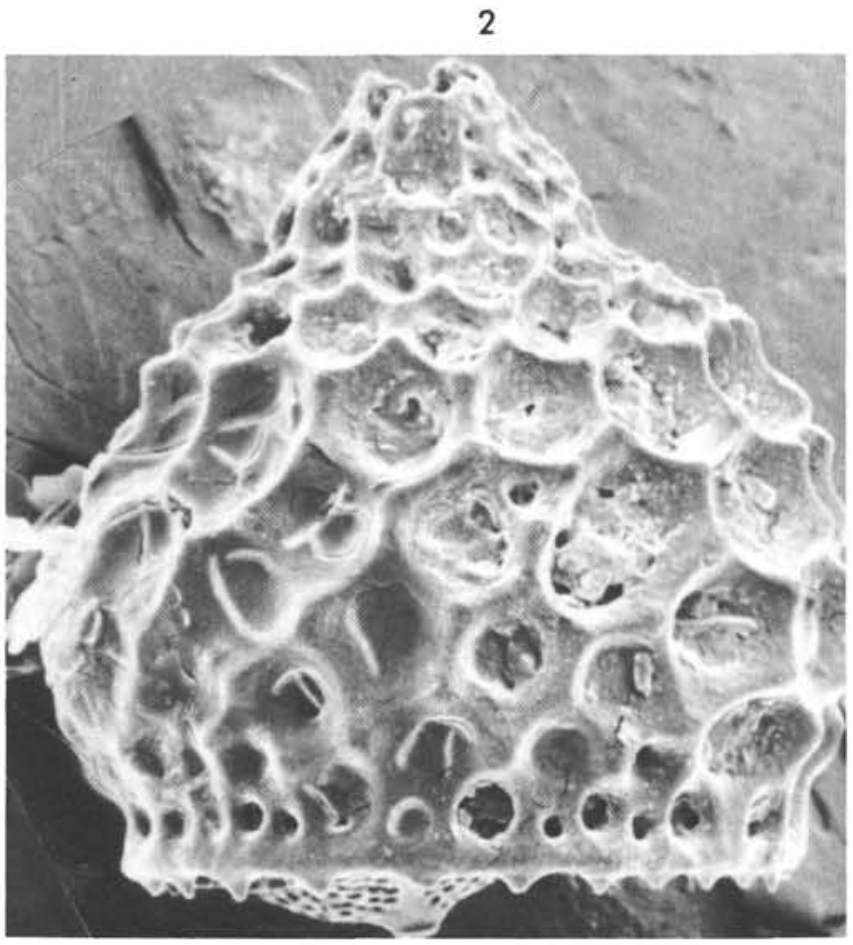

6

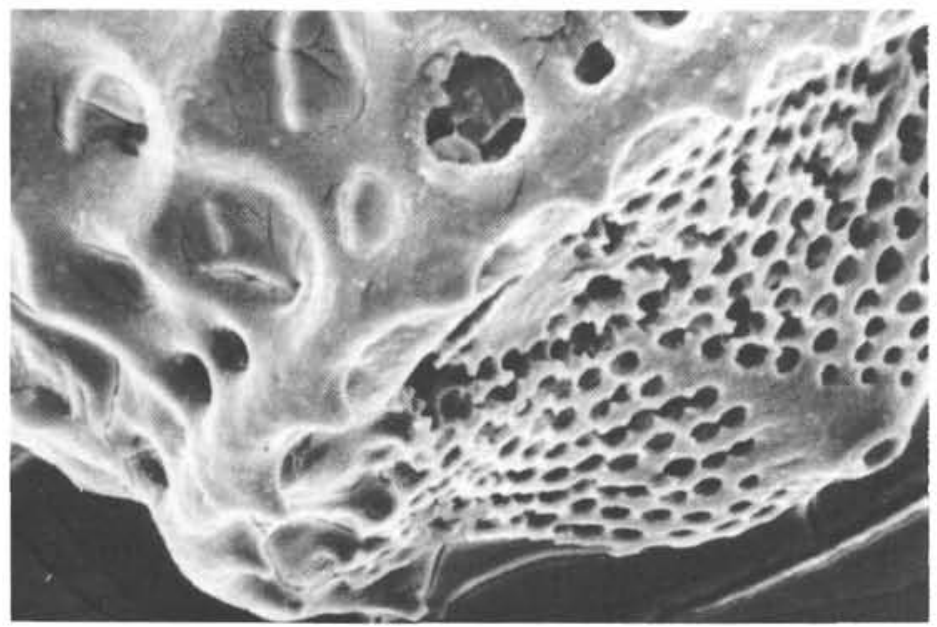

7

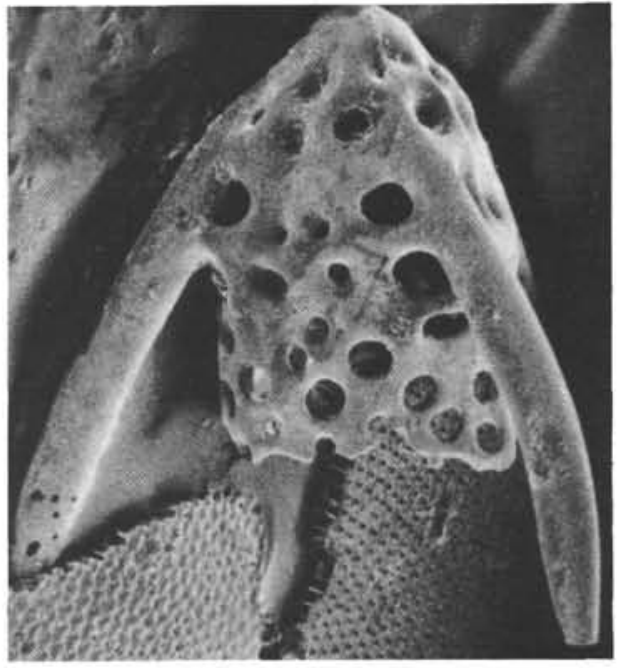

3

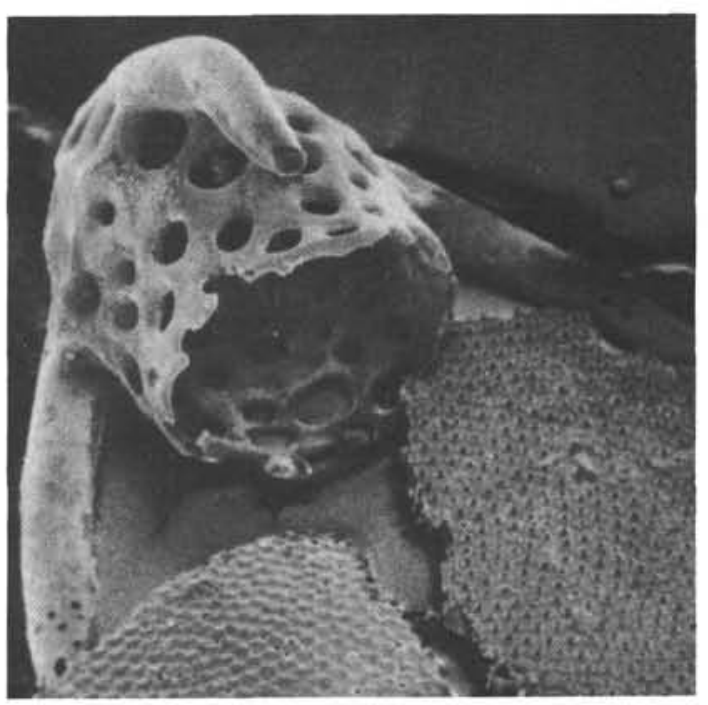

4

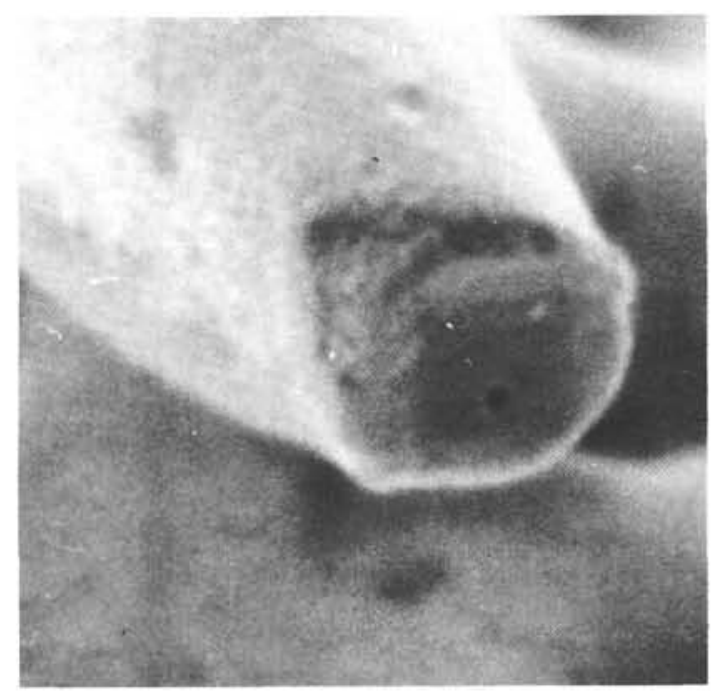




\section{PLATE 44}

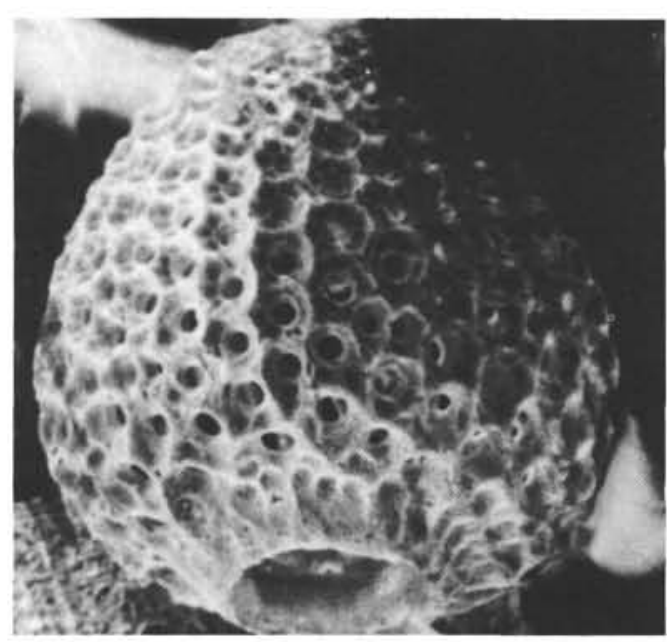

1

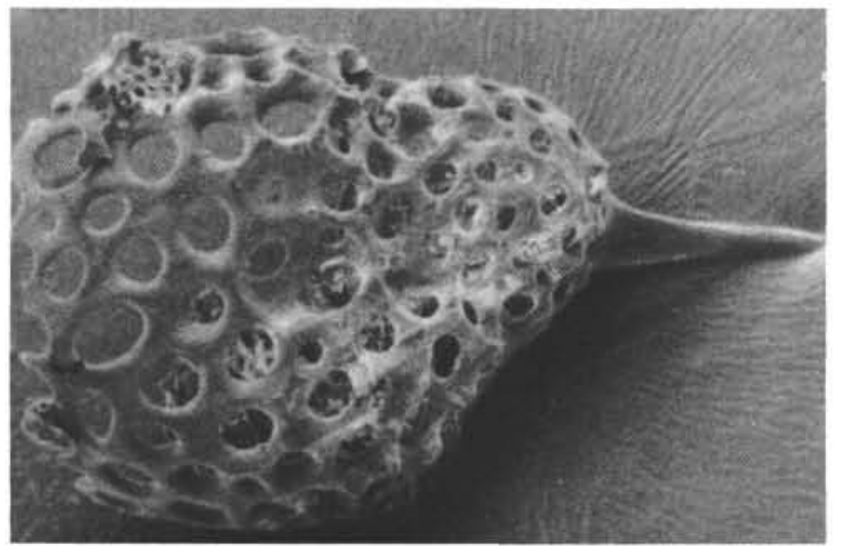

4

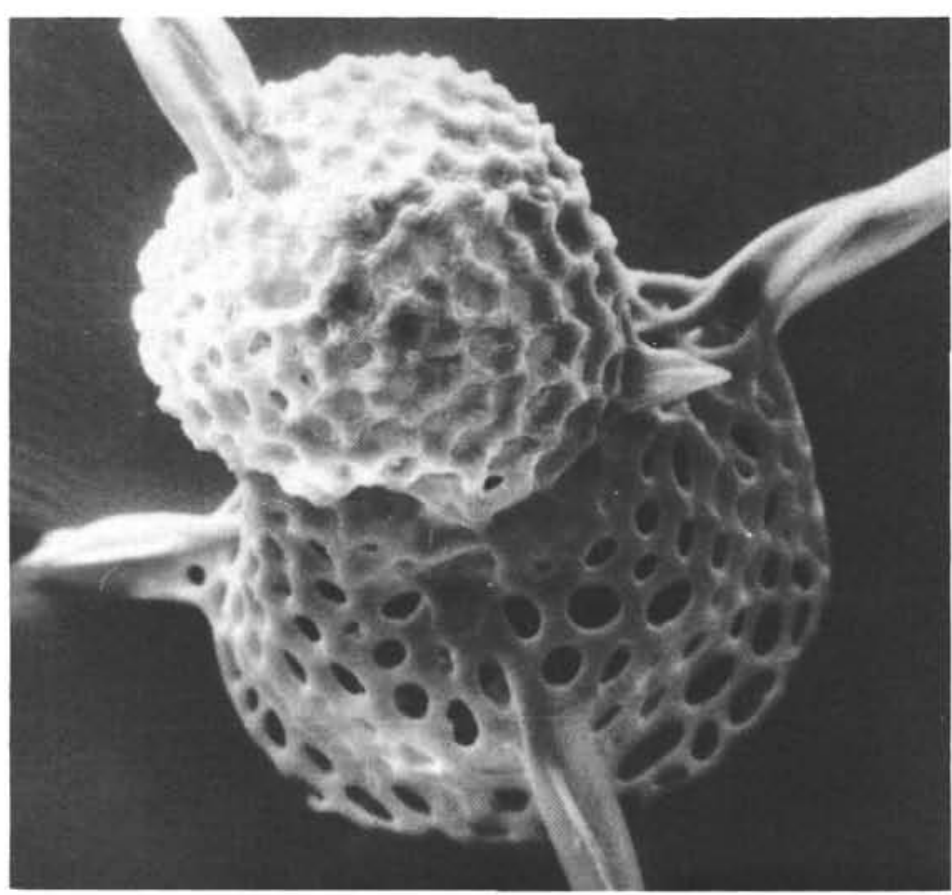

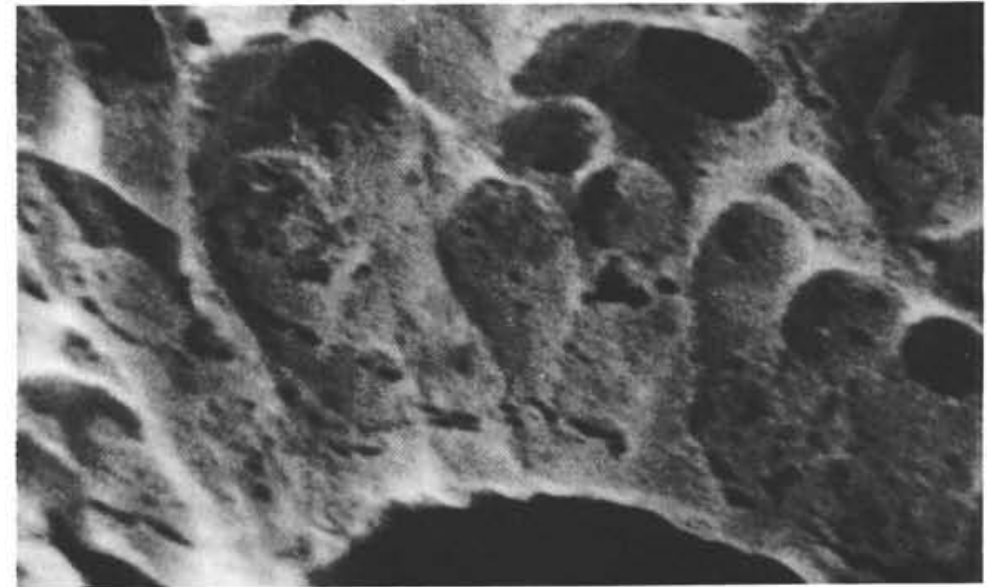

2

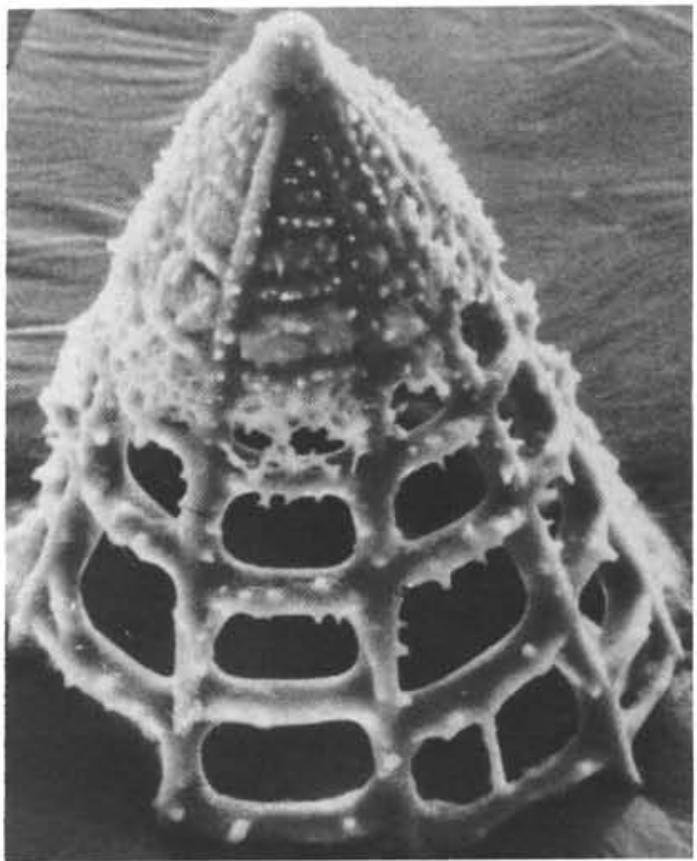

5

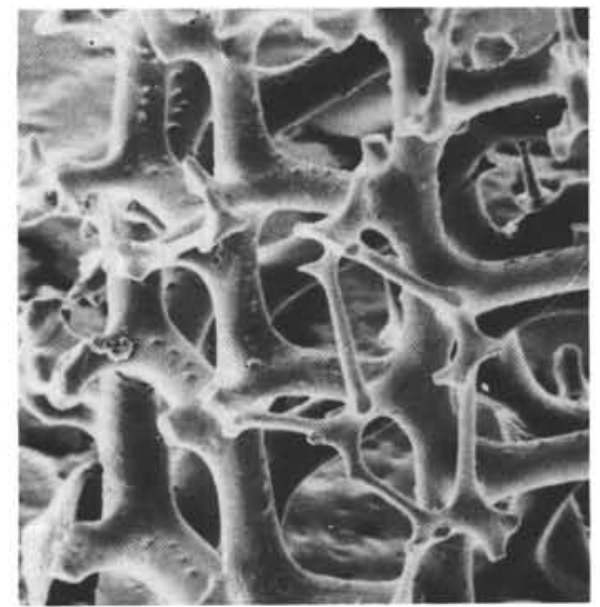

6 